MARILDA LOPES GINEZ DE LARA

\title{
REPRESENTAÇÃO E LINGUAGENS DOCUMENTÁRIAS: bases teórico-metodológicas
}

Tese apresentada ao Departamento de Biblioteconomia e Documentação da Escola de Comunicações e Artes da Universidade de São Paulo, como exigência parcial para a obtenção do título de Doutor em Ciências da Comunicação.

Orientador: Prof. Dr. José Teixeira Coelho Netto

\author{
São Paulo
}

abril de 1999 
Para a mamãe.

Para o Durval, Rodrigo e Fernão. 


\section{AGRADECIMENTOS}

Agradeço ao Prof. Dr. José Teixeira Coelho Netto, meu orientador, pela dedicação e paciência durante o longo percurso desse trabalho.

À Profa. Dra. Maria de Fátima Tálamo, por suas observações críticas fundamentais e pela forma como compartilha seu conhecimento. Pelo seu carinho e amizade.

Ao Prof. Dr. Nilson Machado, pela atenção com que leu meu trabalho e pelas observações no exame de qualificação.

À Prof. e amiga Nair Yumiko Kobashi, pela sua pronta disposição em ler e reler esta pesquisa. Suas observações foram essenciais para a correção de vários problemas deste trabalho.

Aos colegas do CBD-ECA que sempre me incentivaram.

Aos colegas da FESP, pelo apoio.

À Vera Lúcia Tokairim, amiga e primeira mestra no cotidiano das atividades documentárias, pela confiança em meu trabalho no Poupatempo.

À Maria Alice Pompéia Gonzaga, por ter me mostrado a riqueza do trabalho com o universo da informação pública.

Aos muitos amigos da Fundação SEADE, especialmente ao Luis Henrique, Vivaldo e Silvia Rocha, por acreditarem na pertinência de um trabalho com a linguagem.

À Cecília de Lara, pelo incentivo e apoio.

Aos inúmeros amigos que acompanharam esse meu difícil percurso, em especial à Sylvinha, à Mog, à Catarina, ... Pelo seu carinho. 


\title{
RESUMO
}

Abordagem teórico-conceitual da representação documentária e das linguagens documentárias frente aos paradigmas científicos contemporâneos. Nesse sentido, questiona-se o uso exclusivo da definição aristotélica e o modo convencional de enfrentar a polissemia a partir dos seguintes pressupostos: a) de que o conhecimento (e a informação) não são "dados", mas construções; b) de que o conhecimento sistemático deve ser reconstruído a partir do senso comum revestido de parâmetros de racionalidade; c) de que toda representação não é espelho da realidade: seja na Filosofia ou na Linguagem, a representação tem o estatuto de hipótese cuja natureza é sóciocultural; d) de que as representações e as linguagens específicas do campo da Documentação são de natureza lingüístico-comunicacional e veiculam hipóteses de organização baseadas no que se considera circunstancial e temporariamente como informação. As linguagens documentárias não são meras linguagens artificiais. Propõe-se, portanto, a utilização de um conceito de representação documentária fundado nos discursos contemporâneos sobre a representação tematizados pela Filosofia, pela Lingüistica-semiótica, pela Terminologia, pela Socioterminologia e pela Análise Documentária, que se traduzem em requisitos mínimos para a construção de linguagens documentárias que se constituam efetivamente em instrumentos de comunicação.

\begin{abstract}
Theoretic-conceptual approach of documentary representation and documentary languages regarding contemporary scientific paradigms. In this sense, the exclusive use of the aristotelic definition and the conventional manner for dealing with polysemy is questioned taking into consideration the following premises: a) knowledge and information are not "data", but constructs; b) sistematic knowledge must be reconstructed from common sense with added rationality; c) every representation is not a reflection of the real world: either in Philosophy or in Language they are socialcultural hypothesis; d) representation and specific languages in Documentation area have linguistics and communicational nature and express organizational hypothesis about what circumstantially and temporarily is considered information. The documentary languages are not only artificial languages. The use of a concept of representation founded on contemporary discourse in Philosophy, Linguistics, Semiotics, Terminology, Socioterminology and Documentary Analysis are the basis for the construction of documentary languages as effective communication tools.
\end{abstract}




\section{SUMÁRIO}

APRESENTAÇÃ̃ ..........................................................................................

\section{INTRODUÇÃO}

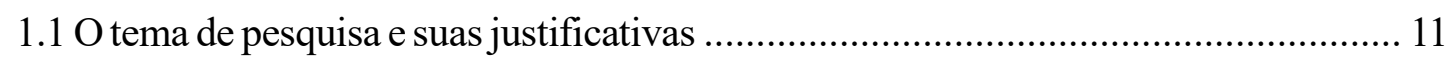

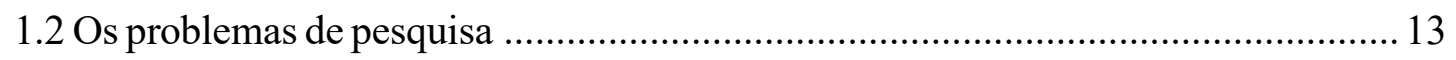

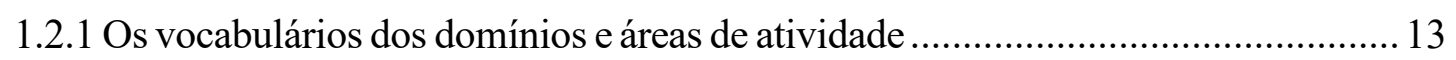

1.2.2 A Terminologia e seus procedimentos para a abordagem de vocabulários .............. 14

1.2.3 A construção de linguagens documentárias ............................................................ 15

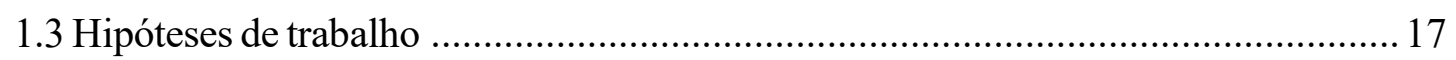

\section{OS PARADIGMAS PARA O DESENVOLVIMENTO DA PESQUISA}

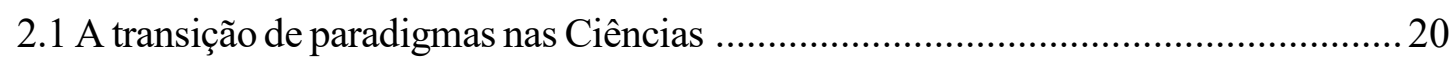

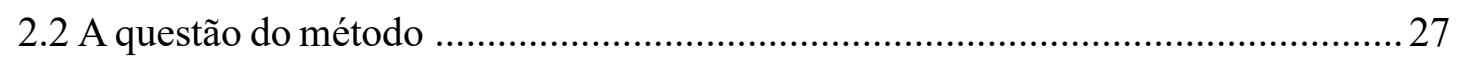

2.3 Os paradigmas nas ciências e a Documentação ......................................................... 31

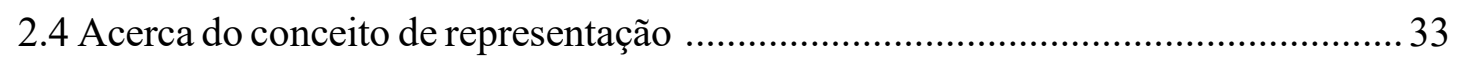

2.4.1 O conceito de representação na Filosofia segundo abordagem de Rorty e

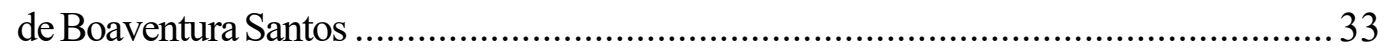

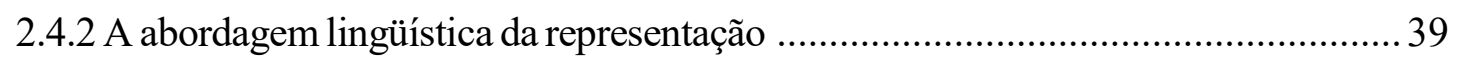

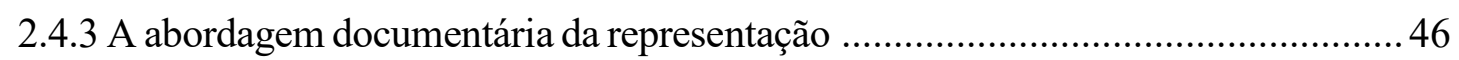

\section{A OPERACIONALIZAÇÃO DOS CONCEITOS LINGÜÍSTICO-SEMIÓTICOS NA CONSTRUÇÃO DAREPRESENTAÇÃO DOCUMENTÁRIA}

3.1 Estrutura lingüística e estrutura das linguagens documentárias 60

3.2 As propriedades estruturais da língua como referência para a construção de linguagens documentárias .63

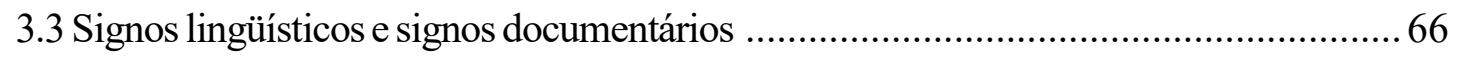

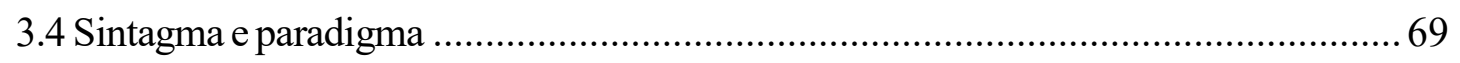

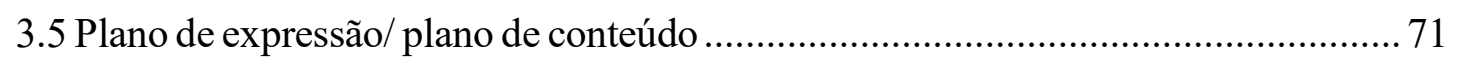

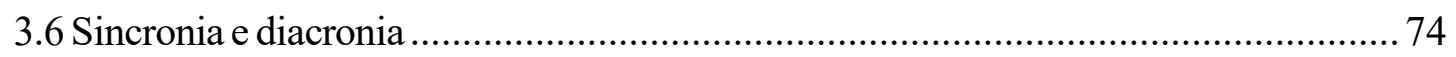

3.7 Langue/parole, forma e substância .................................................................... 75

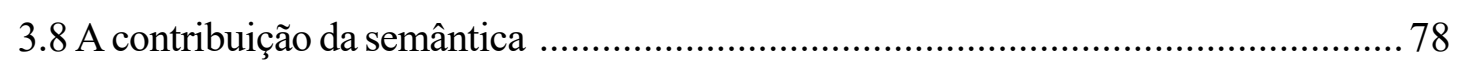

3.9 A comunicação documentária através de uma ótica semântico-semiótica ....................90

3.10 Tradução intracódigo e tradução entre códigos ......................................................... 94

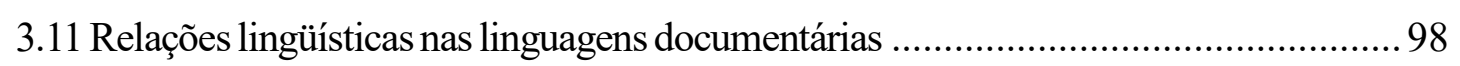

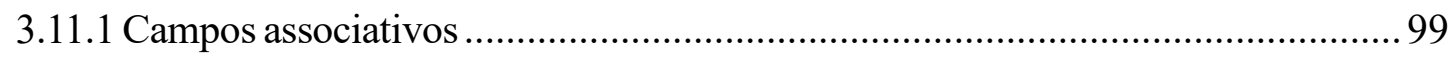

3.11.2 Polissemia, homonímia, monossemia, homossemia ........................................... 101

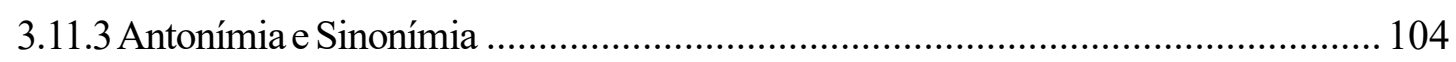




\section{OPERADORES DE SENTIDO PARAAS LINGUAGENS DE REPRESENTAÇÃO DOCUMENTÁRIA: A CONTRIBUIÇÃO DA TERMINOLOGIA}

4.1 A Terminologia: princípios e normas terminológicas ............................................. 108

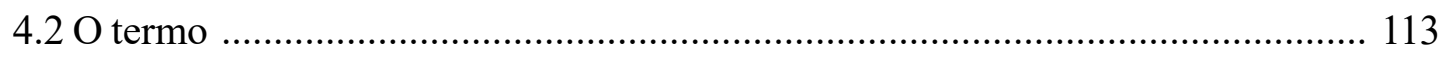

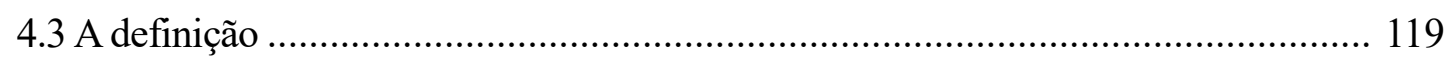

4.4 A construção da definição através das normas ISO 704 e ISO 1087 ................... 122

4.5 A dificuldade para a definição de termos relativos a objetos indeterminados ......... 124

4.6 A terminologia onomasiológica e a terminologia semasiológica ........................... 126

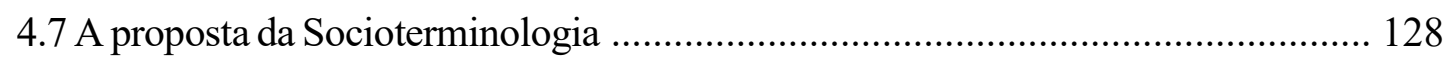

4.8 A Terminologia (e as terminologias) e a Documentação ........................................ 130

\section{PARA UMA DELIMITAÇÃO DO CONCEITO DE REPRESENTAÇÃO DOCUMENTÁRIA}

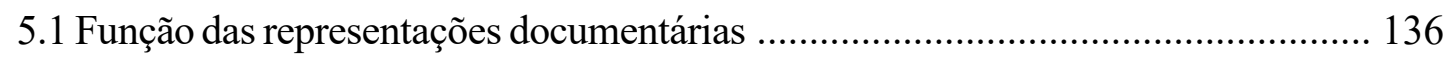

5.2 Tipologia das representações documentárias .................................................... 138

5.3 Modo de funcionamento e interpretação das representações documentárias .......... 140

$5.4 \mathrm{O}$ significado do controle da significação na construção das representações .......... 142

5.5 As representações documentárias e os usuários .................................................. 143

5.6 Representação documentária e conhecimento: limites do modelo tradicional .......... 147

5.7 Representação documentária e possibilidades de apropriação da informação ......... 151

\section{CONCLUSÃO}

Para um conceito contemporâneo de representação documentária:

\section{ANEXO}

A representação da informação pública institucional: exemplos para análise .... 166

Exemplo 1: A representação de informações estatísticas - São Paulo em Dados ........... 169

Exemplo 2: A representação da informação sobre serviços - o Guia de Informações sobre Serviços Públicos

Exemplo 3: A representação da informação sobre sistemas governamentais - o Guia da Oferta de Informações e Sistemas do Governo do ESP 
“... as classificações não são marcas que imprimimos nelas a fogo. São olhares que lhes lançamos do ponto móvel em que nos encontramos, um ponto situado entre as teorias $e$ as práticas sociais que elas convocam".

Boaventura Santos

“... a fixidez é sempre momentânea”.

Octávio Paz 


\section{APRESENTAÇÃO}

Um dos principais objetivos deste trabalho é analisar a representação documentária entendida como representação da informação. A designação "representação documentária" abrange tanto o ato de representar como o produto obtido a partir da ação de representação. Inúmeras designações remetem ao mesmo conceito ou dele se aproximam: sob o ângulo do produto referimo-nos às representações documentárias quando falamos de resumos documentários, índices ou mesmo informação documentária de um modo genérico; sob o ângulo do processo, as designações classificação, indexação, representação temática ou fabricação da informação documentária referem-se todas às operações que caracterizam um processo de representação no âmbito documentário. Enquanto produto ou processo, as diferentes designações dizem respeito a distintos níveis de representação, como também a diferentes pontos de partida para a sua consecução.

Para a Análise Documentária, a noção de representação envolve a construção de "substitutos" de textos, que por uma razão econômica devem ser apresentados de forma compacta para poderem integrar sistemas de informação. A natureza metodológica da Análise Documentária permite, entretanto, transcender à noção de documento “textual”, englobando a representação da informação independentemente da forma de registro e apresentação das informações (informação estatística, informação pública institucional; papel, cds, documentos eletrônicos etc.).

A preocupação com a representação constituiu o foco de atenção principal em nossa pesquisa de Mestrado, quando procuramos investigar os problemas relativos à significação na representação de textos colocada em xeque na ausência de um sistema consistente de relações entre seus elementos, assim como na necessária interdependência textos originais/representação.

A questão continua nos inquietando, particularmente quando a alteração de parâmetros nas Ciências passa a afetar, também, a Documentação. Inúmeras preocupações nos levam a dar continuidade à pesquisa inicial: algumas, mais teóricas, dizem respeito ao estatuto das linguagens documentárias: qual seria o seu nível de comprometimento com os sistemas de idéias? Outras, mais pragmáticas, se relacionam à linguagem de representação de informações de um modo geral, advinda de uma alteração de enfoque que passa a compreender a informação a partir de sua função - minimizando a importância dos suportes ou das formas pelas quais elas são veiculadas - e de vê-la não como um dado, mas como uma construção - o que obriga a analisar os aspectos relativos à sua recepção. De fato, a informação não é nunca um dado objetivo e só tem existência a partir de sua apropriação pelo usuário quando este identifica "do que se fala" e "de onde se fala" (lugar do sentido), a partir de suas experiências e necessidades de conhecimento. O contexto é, assim, fundamental para a produção e/ou recuperação do sentido. 
Supomos que a reflexão teórica sobre a representação documentária fornece meios para avaliar a atividade documentária enquanto prática social. O que, de fato, se "representa" através das linguagens documentárias? A função das linguagens documentárias restringe-se à "reprodução do conhecimento"? O que ela, de fato, reproduz? Qual seria sua função na produção de conhecimento? Como a construção de linguagens documentárias poderia dar conta de papéis significativos na transferência da informação? Como se considera a inserção do usuário? Outras questões também se impõem além da esfera da própria "Lingüística Documentária" ${ }^{1}$ : como interpretar a relação Biblioteconomia/Documentação/Ciência da Informação frente aos parâmetros de uma ciência pósmoderna? É esta uma questão de diferentes graus de enriquecimento teórico ou apenas uma expressão de exigência da pesquisa institucional em termos de poder de negociação? Não nos propomos, nos limites deste trabalho, a responder a todas essas questões, porém elas contextualizam nossas preocupações e são imediatamente responsáveis pelo tema de pesquisa que elegemos. Por outro lado, o modo de enfrentar essas questões tem implicações quanto à forma de conceber uma linguagem de representação.

O estudo da representação no âmbito documentário constitui, portanto, um problema complexo: produção, intermediações e recepção da informação são processos marcados semiologicamente. Representa-se, em Documentação, com objetivos determinados, porém o circuito de representação se realiza completamente quando se instauram condições para a interpretação. Condicionantes de várias naturezas se conjugam para a atualização das "mensagens documentárias" criando, assim, condições para a geração de novos discursos.

A discussão sobre a representação documentária, portanto, transcende os limites estritos da Documentação no seu sentido convencional, já que problemas documentários são, pela sua natureza, problemas de comunicação. Enquanto signos documentários, as representações documentárias não podem ser vistas numa relação simples entre objeto e representação, mas supondo uma relação triádica que compreende objeto, representação e interpretante.

Para abordar questões deste gênero organizamos o trabalho como se segue:

- na introdução estabelecemos o plano geral da pesquisa, delimitando o seu tema, apresentando as justificativas, apontando a identificação dos principais problemas a serem enfrentados e estabelecendo as hipóteses de trabalho;

1 Denominação adotada por García Gutiérrez para se referir ao subdomínio da Documentação que se ocupa com a construção de Linguagens Documentárias (GARCÍA GUTIÉRREZ, 1990). 
- no segundo capítulo, procuramos situar a questão da representação no contexto da alteração dos paradigmas que atravessa a ciência de um modo geral, verificando como ela tem sido abordada pela filosofia (e ciências de um modo geral) e pela lingüística. Essas referências nos permitem situar, historicamente, a representação no âmbito documentário;

- no terceiro capítulo, contemplamos a representação documentária segundo parâmetros lingüístico-semióticos. A partir de analogias, procuramos verificar como os conceitos lingüísticos podem ser assimilados para compreender a natureza comunicacional das representações documentárias, bem como para estruturar linguagens documentárias;

- uma vez que consideramos a Terminologia, enquanto disciplina teórica e prática, referência para a construção das linguagens documentárias, reservamos o quarto capítulo para a análise e discussão de seus princípios e propostas. Ao considerarmos a possibilidade de as terminologias concretas funcionarem como operadores de sentido para as linguagens documentárias, procuramos discutir problemas e sistematizar algumas das contribuições decorrentes da concepção implícita de representação das normas terminológicas;

- no quinto capítulo, a partir das contribuições precedentes, procuramos delimitar um conceito operacional de representação documentária discutindo suas funções, tipologia, modo de funcionamento, condições de interpretação. Procuramos, também, verificar os limites de um modelo tradicional e as possibilidades de apropriação da informação documentária;

- na conclusão, apresentamos uma sistematização das reflexões realizadas e enumeramos os requisitos para um conceito contemporâneo de representação documentária a partir do qual é possível falar efetivamente em linguagem documentária;

- como ilustração apresentamos, em anexo, o relato de três experiências de construção de representação de informações públicas institucionais, através de propostas de linguagens onde tornam-se mais explícitos os problemas relacionados ao deslocamento da prioridade do documento para a sua função, e onde ficam mais evidentes as possibilidades de reconstrução do senso comum a partir de critérios de racionalidade. 


\section{INTRODUÇÃO}

\subsection{O tema de pesquisa e suas justificativas}

O tema desta pesquisa - o estudo da representação documentária - insere-se no contexto anteriormente explicitado e justifica-se enquanto tentativa de identificar os requisitos teóricos e práticos para a construção de linguagens documentárias como instrumentos de representação, organização e transferência da informação.

Partimos do princípio que é fundamental observar que a atividade de representação, ao desenvolverse no universo da linguagem, envolve não apenas a utilização do código lingüístico, mas toda uma série de fatores que a caracterizam como prática social.

Nosso objeto teórico é a representação documentária de um modo geral, materializada nas diferentes linguagens documentárias, objetos empíricos a partir dos quais é possível verificar princípios gerais de estruturação, funções, potencial de transferência da informação e receptividade.

O padrão das linguagens documentárias é normalmente desenhado tendo como parâmetro a representação de textos técnico-científicos. A alteração de ênfase do documento para sua função, porém, sugere a flexibilização do termo, para abrigar, também, a representação de informações que não caracterizam, necessariamente, uma linguagem documentária no seu sentido tradicional. Partimos do pressuposto de que a construção do sentido é dependente do contexto e que a informação não é nunca um dado objetivo. Em princípio, acreditamos que é preciso identificar as características dos vocabulários específicos relativos a cada domínio do conhecimento ou área de atividade e que a Terminologia ${ }^{2}$ (a ciência terminológica) pode instrumentar a coleta terminológica no sentido de assegurar delimitações consistentes dos termos e construção de definições funcionais. No desenvolvimento do trabalho procuraremos verificar se as normas terminológicas existentes são adequadas ao tratamento dos variados gêneros de vocabulário, incluindo as situações onde não domina a estabilidade conceitual, característica presente nos domínios em formação ou transformação.

A dupla busca pela terminologia - concreta e teórica - tem como objetivo referendar o processo de construção das representações. Através da terminologia acreditamos ser possível qualificar o

2 Utilizaremos, para fins de entendimento, Terminologia com "T"maiúsculo para referirmo-nos à Ciência da Terminologia e terminologia, com " $t$ " minúsculo, para a terminologia enquanto objeto concreto. 
trabalho da coleta das unidades que deverão funcionar na intermediação, julgando ser tal procedimento mais eficiente do que aqueles baseados, seja no empirismo, seja na identificação da freqüência e ocorrência dos termos ou registros informacionais na literatura. Por sua vez, acreditamos que a Terminologia enquanto área de estudo, provê método e delineia procedimentos para a realização do trabalho.

Do ponto de vista teórico partimos do pressuposto de que a representação da informação é sempre uma hipótese e uma construção, não existindo propostas imunes à revisão. Isso implica rejeitar uma lógica baseada no “dever-ser", que caracteriza os modelos cartesiano e kantiano, para procurar parâmetros que privilegiem a utilidade sobre a racionalidade e cientificidade.

A ênfase na transferência da informação altera os padrões de representação. De fato, a noção de divulgação da informação manteve-se, durante muito tempo, eclipsada pela noção de preservação de documentos. Associada à característica de permanência da escrita, a noção de preservação neutralizou a de disponibilidade a que também deveria estar relacionada (TÁLAMO, 1997, p.2). Subjacente à idéia de preservação, a noção de representação esteve ligada à suposição de que a integridade física dos acervos e o acúmulo seriam condição para o conhecimento.

A preocupação com a preservação documental, embora não negada, é substituída pela do uso da informação como meio de promover conhecimento. Como conseqüência, substituem-se os padrões canônicos de representação baseados na ordem racional e cientificista estabelecidos a partir de um ponto fixo de enunciação por procedimentos que utilizam uma lógica do "poder fazer" e do "poder ser" que permite contemplar a diversidade de hipóteses e a multiplicidade de funções da informação. A idéia do "dever ser" tem um caráter normativo, é conseqüência necessária, movendo-se segundo uma lógica dura e obedecendo a um raciocínio dedutivo. Ao contrário, uma dimensão pragmática permite considerar a alteridade, a multiplicidade dos pontos de vista, transformando o "dever ser" em “poder ser", que tem como conseqüência em última análise, a transformação do "fazer".

A relativização das coisas é sua expressão mais clara, trazendo em si novos paradigmas para a abordagem dos objetos e fenômenos. E se, por natureza, o processo de representação documentária via linguagens documentárias é redutor, impõe-se verificar os limites dessas reduções de modo a possibilitar aberturas interpretativas. Se o caráter prescritivo e normalizador das linguagens documentárias não pode ser facilmente abandonado, uma vez que é da natureza da atividade documentária gerar indicadores de informação, ao menos é viável supor que esses indicadores funcionem semioticamente, permitindo a construção da informação que gera conhecimento.

Esse fato, por si só, inviabiliza a construção de linguagens documentárias objetivas, estáveis e duradouras. Parafraseando Rorty, só podemos “alcançar objetivos transitórios e resolver problemas 
transitórios" (RORTY, 1994). A informação é, por natureza, atomizada, temporária e particular, Conseqüentemente, as linguagens documentárias não podem se restringir a garantir a "perenização" de acervos (segundo uma noção estática de conhecimento), mas devem se constituir em ferramentas de “organização e recuperação da informação" (voltadas à noção dinâmica de conhecimento).

\subsection{Os problemas de pesquisa}

Os problemas mais amplos colocados para a Documentação (e Ciência da Informação) de um modo geral, apontados anteriormente, não serão diretamente objeto de nossa pesquisa, porém contextualizam nossas perguntas surgidas no âmbito deste trabalho. Nossos problemas específicos podem ser agrupados em três itens: problemas de abordagem dos vocabulários dos domínios e áreas de atividade; problemas relacionados ao modo como a Terminologia delimita seus procedimentos para abordagem dos vocabulários de uma maneira geral; problemas relacionados à estruturação de linguagens documentárias propriamente ditas frente às contribuições da Lingüística, da Filosofia e da própria Documentação.

\subsubsection{Os vocabulários de domínios do saber e de áreas de atividade}

Tradicionalmente, opõem-se os vocabulários das áreas “duras", das ciências exatas, ao das áreas "moles", ou ciências humanas em geral. Contemporaneamente, entretanto, não mais é possível admitir essa distinção, já que a estabilidade que caracterizava as primeiras está sob suspeita (as áreas exatas foram, na verdade, pioneiras em colocar em xeque tal estabilidade). Uma oposição estabelecida a partir do grau de compartilhamento de vocabulários poderia ser um critério utilizável. Porém, mesmo a suposição desse compartilhamento não significa uniformidade de interpretação conceitual, pois a utilização de determinados termos não remete, necessariamente, às mesmas significações.

As alterações de parâmetros atingem igualmente distintas áreas. A delimitação rígida entre disciplinas não resiste à análise, já que as ciências e as atividades transformam-se cotidianamente passando a ser caracterizadas pela trans e interdisciplinaridade. Áreas de estudo e de trabalho que gozavam de relativa autonomia vêem-se, hoje, atravessadas pelo intercâmbio de conceitos e métodos, perdendo seus contornos rígidos e as características que, até bem pouco tempo, poderiam identificálas como estáveis.

Exemplo disso é a delimitação da noção de cultura. Resultado de uma convivência no espaço e no tempo da modernidade e da pós-modernidade, a noção de cultura varia, hoje, de uma concepção 
mais clássica - cultura oposta à natureza - à uma concepção onde a natureza integra-se à cultura. Essa variação expressa o resultado de uma alteração da própria organização do pensamento humano e implica modificações na sua função social. A cultura deixa de pertencer a uma esfera autônoma explodindo dentro do reino social e transformando todas as coisas e ações em atos culturais (JAMESON, 1991).

Como conseqüência, a construção de representações documentárias, cujo princípio era o de procurar a invariância, passa agora a ser o de trabalhar com a variação. $\mathrm{O}$ enfrentamento dos vocabulários com o objetivo de constituir linguagens documentárias não pode se furtar a observar a variabilidade de manifestações teórico-conceituais, sob pena de não se adequar efetivamente à representação.

A escolha do vocabulário a ser utilizado nas linguagens documentárias também depende do tipo de usuário visado pelo sistema de informação. Se os usuários são bem determinados, pode-se trabalhar com vocabulários considerando seu grau de compartilhamento. Ao contrário, quando eles são relativamente indeterminados, trata-se de encontrar mecanismos para integrar a variação, como único meio de contemplar diferentes tipos de usuários com distintas competências para assimilar a informação.

Consideradas as dificuldades e especificidades dos distintos vocabulários, quaisquer que sejam os universos de informação focalizados (vocabulários acadêmicos, profissionais, etc.) seu enfrentamento requer considerar que as opções de representação serão sempre hipóteses, constituindo modos sociais determinados de atribuição de significado.

\subsubsection{A Terminologia e seus procedimentos para a abordagem de vocabulários}

Pode-se afirmar que as normas terminológicas foram elaboradas tendo como parâmetro um modelo de ciência no qual 'rigor' estava necessariamente ligado à 'cientificidade'. A maior parte dos procedimentos adotados direciona-se, conseqüentemente, à abordagem da literatura dita técnicocientífica, justificada mesmo pelas necessidades colocadas pelo desenvolvimento tecnológico de um modo geral e pela dominância do modelo racional cartesiano/kantiano. A principal referência nessas normas para a construção do conceito (e delimitação do termo) é um objeto extralingüístico palpável, um objeto concreto.

Segundo o modelo "moderno" de ciência - que embora hoje questionado ainda é largamente utilizado - a referência exterior é um dado admitido como passível de objetivação. Enquanto marco da modernidade, todavia, "um objeto não é necessariamente igual a si mesmo, variando 
conforme o ângulo de observação" (TEIXEIRA COELHO, 1995, p.27). Embora a Terminologia admita que o domínio e a função definem o ponto de vista, seus parâmetros tendem, ainda, a seguir o modelo anterior, a não ser pelos poucos questionamentos hoje colocados por parte da literatura terminológica que privilegia a descrição sobre a prescrição. Na maior parte das vezes as normas terminológicas são um exemplo - a terminologia é essencialmente normativa.

Outro problema relaciona-se ao modo como a Terminologia pode e deve dar conta da alteração dos padrões de conhecimento. Como analisar o parâmetro da definição utilizada pela Terminologia - a definição aristotélica - se, ao menos teoricamente, a definição enciclopédica seria o modo mais adequado de dar conta do novo conceito de conhecimento? Certamente a Terminologia adota um modelo de definição que se organiza em árvore porque trabalha com a hipótese de controle e normalização. Já a definição enciclopédica que, paradoxalmente, significa encadeamento de conhecimentos (DIDEROT, 1989), é de natureza semiótica - e não assume, necessariamente, a forma de árvore.

Para Deleuze \& Guattari, o modelo da enciclopédia semiótica se organizaria em rizoma, "onde cada ponto pode e deve ser unido a qualquer outro ponto" (DELEUZE \& GUATTARI, apud ECO, 1991, p.115). Mas, sintomaticamente, o rizoma é concebido como uma "rede de árvores que se abrem em toda direção" (...) que "não tem centro" (idem ibidem). Para Eco, "a idéia de uma enciclopédia como rizoma é conseqüência direta da inconsistência de uma árvore de Porfírio" (ECO, 1991, p.115). O fato de permanecer como uma possibilidade virtual - a árvore é sempre utilizada como uma "descrição provisória" para dar conta de porções da enciclopédia - demonstra que ela não é imediatamente operacionalizável.

O problema é que, à definição enciclopédica (ou definição semântico-semiótica) talvez não se deva opor a definição aristotélica. A definição enciclopédica altera o sentido vertical de leitura - pressuposto moderno - para sugerir uma multiplicidade de possíveis leituras, verticais, horizontais e diagonais. Só dessa forma a definição poderia dar conta de sentidos plurais e permitiria interpretações semióticas. A realidade não é representável, mas só demonstrável, e um dos modos de se falar disso é que "em termos topológicos ... não se pode fazer coincidir uma ordem pluridimensional (o real) e uma ordem unidimensional (a linguagem)" (BARTHES, 1971, p.22). A Terminologia deveria encaminhar a resolução desse problema através da criação de condições para a identificação das "enciclopédias locais".

\subsubsection{A construção de linguagens documentárias}

Uma linguagem documentária é um instrumento através do qual se realiza a "tradução" da 
síntese do conteúdo de textos e das perguntas dos usuários para a linguagem do sistema. É formada por um conjunto de termos, providos ou não de regras sintáticas, utilizado com fins de classificação ou busca retrospectiva de informações (GARDIN et al., 1968). Integram uma linguagem documentária um léxico selecionado, uma rede de relações lógicosemânticas entre suas unidades (que dá forma e reflete os paradigmas utilizados em sua construção) e, eventualmente, uma rede sintagmática destinada a expressar as relações contingentes entre as unidades.

Dentre os vários tipos de linguagens documentárias, os sistemas classificatórios têm sido questionados pela literatura documentária quanto à sua adequação para o tratamento de conteúdos de textos. Os exemplos de linguagens documentárias com recursos maiores de sintagmatização constituem casos raros na literatura: embora interessantes, são sistemas extremamente complexos, e apresentam, por isso mesmo, problemas de ordem econômica para sua construção e utilização. São os tesauros, todavia, as linguagens documentárias sobre as quais a literatura volta mais sua atenção.

A teorização sobre a prática de construção de tesauros é muito recente. É significativo verificar que, do mesmo modo que a Terminologia, os padrões e normas para construção de linguagens documentárias contemplam áreas onde domina relativa estabilidade. Não se pode afirmar, entretanto, que a Documentação, como a Terminologia, conte com 'procedimentos' mesmo para tratar domínios estáveis, que possam ser considerados suficientemente rigorosos para orientar a elaboração de instrumentos de intermediação documentária. As orientações são, na maioria das vezes, de caráter normativo e, no caso da Documentação, não se aprofunda a relação que se estabelece com as normas terminológicas (caso da norma ISO 2788 - British Standard Guide to establishment and development of monolingual thesauri). Observa-se, além disso, que a norma para construção de tesauros segue parâmetros exclusivamente lógicos, não existindo qualquer menção à natureza lingüístico-comunicacional que caracteriza tais instrumentos de intermediação documentária.

A análise de algumas das principais linguagens documentárias permite afirmar, também, que um dos principais problemas para sua construção e uso está na forma como se trabalha a significação de suas unidades (LARA, 1993). Como afirma García Gutiérrez, a partir do isolamento terminológico que precede sua construção "as relações que conformam sua estrutura não se realizam em função do campo discursivo representado senão mediante mecanismos de expansão e oposição gerados em um sistema distinto" (GARCÍA GUTIÉRREZ, 1990, p.71-72). A manutenção da referência ao discurso individual é impossível por uma questão econômica (e nem é esse o objetivo das linguagens 
documentárias que são, pela sua própria natureza, generalizantes). A alternativa, portanto, é buscar referência na terminologia de domínios particulares e, indiretamente, recuperar as relações entre as unidades do discurso que dão forma aos conceitos por eles veiculados ${ }^{3}$.

O significado das palavras nos discursos de domínios e áreas de atividade é explicitado a partir e no universo desses grupos particulares, reproduzindo seus padrões valorativos e cognitivos, sua estrutura e processos. A terminologia constitui, assim, o lugar privilegiado para a convergência dos vários discursos correlatos, sejam eles contrários ou contraditórios. A Terminologia, preocupada em "mapear" os conceitos de domínios, permite restaurar a referência a esses domínios, bem como oferece procedimentos orientadores para a identificação e/ou construção de vocabulários específicos.

Outro problema fundamental a ser enfrentado relaciona-se ao usuário. Em que medida ele é realmente contemplado? A terminologia de domínios é, em si, suficiente para dar conta de suas necessidades? Em que medida a Terminologia contempla a linguagem do usuário, mesmo especializado? Como pensar a negociação de sentido através das linguagens documentárias? Como tratar a questão do significado do ponto de vista da recepção? Estes são alguns dos problemas a serem enfrentados dentro da problemática ligada à estruturação das linguagens documentárias. De qualquer modo, o conceito de representação deve ser investigado.

\subsection{Hipóteses de trabalho}

Duas são as hipóteses de trabalho que levantamos a partir da delimitação dos problemas de pesquisa: a primeira, é que o conceito clássico de definição (o conceito aristotélico) adotado pelas normas terminológicas não é suficientemente potente para subsidiar a estruturação de linguagens documentárias, particularmente em áreas emergentes e transdisciplinares. Pode-se questionar, ainda, se a definição nos moldes aristotélicos é o único meio de aceder ao significado. A segunda hipótese é a de que, contrariamente ao que postulam a Terminologia e as normas para a construção de linguagens documentárias, acreditamos ser imprescindível considerar a polissemia, enquanto

\footnotetext{
3 De fato, a Análise Documentária não mais postula o discurso como seu ponto de partida. Como observamos em trabalho anterior, "o discurso é um objeto concreto e se propõe invariavelmente como expressão de subjetividade, isto é, apropriação da língua por um 'Eu' definido. Analisá-lo implica, portanto, extrapolar os aspectos que alguns teóricos consideram puramente lingüísticos do texto ... a Análise do Discurso propõese como um empreendimento multidisciplinar que busca, na pesquisa das condições de produção ... o seu modo de articulação específico. Assim sendo, cada discurso é único, e a análise tem como objeto discursos individuais ou corpus bastante restritos..." (LARA, 1993, p.39-40). É o texto - unidade organizacional coerente e coesa - que pode ser considerado como ponto de partida da Análise Documentária. "Enquanto no discurso se expressa o sentido - apropriação individual da significação articulada pelo sistema - no texto manifesta-se a significação como veículo de informação" (idem ibidem, p.40).
} 
fenômeno lingüístico, para abordar o espectro de termos que representam, justamente, o caráter dinâmico e transformacional de distintas áreas de especialidade.

Um pressuposto básico orienta a própria colocação dessas hipóteses: o de que o caráter normativo das recomendações, se tem sua importância, deve ser assimilado criteriosamente. Toda norma é, pela sua própria natureza, uma emanação de autoridade e tem como objetivo introduzir procedimentos metodológicos ao desenvolvimento de atividades. Ao utilizar uma norma, automaticamente utilizamos os padrões a ela subjacentes. Quando os padrões começam a ser questionados, a norma deve, automaticamente, ser criteriosamente discutida, procurando-se novos pontos de partida para sua sustentação. As hipóteses levantadas remetem a questionamentos ao cerne das normas.

Sob esta ótica, as duas hipóteses se relacionam: procuramos extrapolar o conceito de definição proposto pela Terminologia para pesquisar a possibilidade de adotar o conceito de definição semântico-semiótica para a construção das linguagens documentárias, acreditando ser ele mais adequado à abordagem da polissemia presente nos vocabulários de um modo geral.

A definição clássica segue padrões canônicos. Definições semióticas deveriam permitir agregar, aos sentidos determinados pela definição canônica baseada na oposição gênero/espécie, outras significações indefinidas instauradas a partir da experiência. A definição clássica é essencialmente dedutiva e serve de base à delimitação de domínios estáveis, uma vez que permite falar claramente de propriedades (ou características) de objetos pertencentes a classes. Mas o processo dedutivo não é suficiente para tratar domínios onde há variação conceitual, onde as metáforas são elementos constantes e onde as analogias não se organizam necessariamente de modo lógico.

A principal característica da definição aristotélica - bem como sua reinterpretação por Porfírio na árvore do universo - é a implicitação, sendo as relações entre seus termos realizadas através, principalmente, do encaixe lógico. A definição semântica segue, basicamente, o mesmo modelo. A definição semiótica, embora se utilize do modo de operacionalização da definição aristotélica, tende a ser mais flexível e pragmática. A grande diferença entre uma e outra é que a definição semiótica tem caráter enciclopédico, e "a enciclopédia não pode ser uma reserva de argumentos possíveis, porque os argumentos possíveis são infinitos" (ECO, 1984, p.117). Anoção de definição semiótica, entendida como uma definição não exclusivamente dedutiva lança mão, por exemplo, dos "frames" (ou encenações) ou seja, além de considerar as características e propriedades dos termos, inclui a possibilidade de instruções que se referem a vários casos prováveis (idem ibidem).

O princípio de definição semiótica centra-se no objeto - e não mais na classe, sendo por isso mais característico de uma semântica intensional do que extensional. Cada objeto refere-se a uma 
aplicação e se formos proceder a análise a partir de cada situação onde ele ocorre, teremos de enfrentar inúmeras árvores, pois esse objeto deverá ter inúmeras definições que variam segundo o contexto onde se inserem. O que pretendemos é explorar a noção de definição semântico-semiótica partindo do pressuposto de que ela permite integrar as várias possibilidades de ocorrência do objeto. Dito de outro modo, a perspectiva desejada desvia o foco de atenção da cadeia dedutiva - da primeira definição e das definições derivadas - para as possibilidades associativas horizontais ou determinadas contextualmente. Não partimos da premissa de que uma coisa é, mas de que funciona de determinada maneira segundo o contexto e as circunstâncias de enunciação. Do ponto de vista prático, visualiza-se a possibilidade de utilizar, simultaneamente, tantas definições quantas forem julgadas necessárias para dar conta de uma pluralidade de leituras e de integrar, nelas, elementos que permitam estabelecer os processos a partir dos quais ela possa desencadear novas leituras.

Quanto à polissemia, sabemos que a Terminologia, de um modo geral, busca a precisão buscando a "univocidade" de significação. Salvo raras exceções na literatura terminológica, a univocidade é parâmetro para a definição de termos, e a Terminologia pretende que a cada forma deva corresponder um só sentido e vice-versa.

Não é possível, entretanto, aceitar rigidamente esse pressuposto ao trabalhar com universos que se transformam continuamente. Se admitíssemos, por exemplo, uma definição excludente, teríamos linguagens documentárias unidimensionais, ao modo de cadeias cartesianas, com elos construídos "linear e paulatinamente", ordenando-se "por uma bem definida hierarquia" que nos conduziria "do mais simples ao mais complexo, não se hesitando em delimitar com nitidez critérios de simplicidade/complexidade" (MACHADO, 1995, p.30).

É óbvio, entretanto, que qualquer organização vocabular se pauta numa definição que, por sua vez, orienta uma hierarquia. Nossa hipótese é de que várias hierarquias convivem no espaço-tempo e que as relações horizontais, diagonais, dentro e entre hierarquias, contribuem para a definição dos pontos de vista selecionados para a organização vocabular e para a delimitação da significação.

Se nos ativermos, portanto, à univocidade para a organização do vocabulário, estaremos reproduzindo um ponto de vista entre outros, uma vez que a dinamicidade, a pluralidade dos discursos, faz uso do caráter polissêmico da língua para construir novas idéias. A metáfora e a analogia constituem, sob esse aspecto, fonte de novas significações. 


\section{OS PARADIGMAS PARA O DESENVOLVIMENTO DA PESQUISA}

Para realizar a discussão sobre os instrumentos de representação documentária é necessário esclarecer, anteriormente, qual é o nosso ponto de partida epistemológico. Essa explicitação implica uma apreciação sobre o pensamento da Documentação onde a questão dos instrumentos de representação documentária se insere, bem como a maneira como ela se situa no contexto mais amplo da história das idéias.

Nosso problema de pesquisa não poderia ser abordado sem anteriormente formular o conceito de representação com que operamos. A atividade de representação documentária se debruça sobre o conhecimento, o que torna imprescindível identificar em que bases se assenta essa relação e, conseqüentemente, o que entendemos por conhecimento. Ao lado do caráter eminentemente prático da representação documentária - representar conteúdos - é necessário considerar, pois, que uma concepção de representação é subsidiária de um modo de se relacionar com o mundo, o que caracteriza um problema de ordem epistemológica.

Historicamente, o tratamento da questão não é consensual e as concepções de representação têm variado à medida da variação do modo de ver a relação com o mundo. Por outro lado, a transição de paradigmas que caracteriza o momento em que vivemos repõe o problema sob nova ótica, redefinindo os modos de conceber o conhecimento. Sendo uma das funções da representação documentária realizar a mediação para o conhecimento, pode-se afirmar que ela seja, também, uma forma de conhecimento, ou que, pelo menos, traga implícita uma idéia de conhecimento. Desse modo, não está imune às transformações provocadas pela alteração de paradigmas nas ciências.

Além disso, as representações documentárias se realizam no universo da linguagem, o que torna necessário integrar à discussão os conceitos de mediação e de modelização. A concepção de conhecimento e do modo de conhecer determinam, portanto, a definição de representação em Documentação.

\subsection{A transição de paradigmas nas Ciências}

No âmbito da discussão sobre o momento em que vivemos, caracterizado pela fase de transição entre o paradigma da ciência moderna e o da pós-moderna, a Documentação constitui um caso particular: primeiro, porque a discussão sobre seu estatuto - ciência ou técnica - ainda não findou, e isso poderia caracterizá-la como vivendo uma "crise de crescimento" quando há "insatisfação 
perante métodos ou conceitos básicos até então usados" (SANTOS, 1989, p.18): a própria denominação que a ela se dá ou a que ela aspira - Ciência da Informação - é um sintoma; segundo, porque ela não é imune à "crise de degenerescência" da ciência a que assistimos. "As crises de degenerescência são crises do paradigma, crises que atravessam todas as disciplinas, ainda que de modo desigual, e que as atravessam a um nível mais profundo. Significam pôr em causa a própria forma de inteligibilidade do real que um dado paradigma proporciona e não apenas os instrumentos metodológicos e conceituais que lhe dão acesso" (SANTOS, 1989, p.18).

A reflexão epistemológica decorrente se revela, no interior da Documentação, do mesmo modo que para o conjunto das disciplinas, como a "consciência teórica da precariedade das construções assentes no paradigma em crise". O conhecimento científico deixa de ser concebido como o modo privilegiado de saber para se tornar uma prática, como tantas outras.

Para melhor compreendermos como deve ser levada a efeito a reflexão epistemológica no âmbito da Documentação é necessário, primeiro, verificar como essa discussão se coloca para o conjunto das ciências e da história das idéias de um modo geral.

Ao passar a conceber o conhecimento científico não mais como um modo privilegiado do saber mas como uma prática entre outras, a crise de degenerescência acaba por implicar um movimento de desdogmatização da própria ciência, o que coloca em crise, conseqüentemente, a própria epistemologia. O modo de enfrentar a crise da epistemologia, entretanto, não é consensual.

Sob o ponto de vista de Rorty, a necessidade de uma epistemologia é um resquício do pensamento moderno, como um "desejo de constrangimento", de insatisfação e descontentamento. É também um desejo de encontrar fundamentos, um "desejo de comensuração", bem como a procura de "representações privilegiadas". A solução pragmática do problema do conhecimento consiste em "sermos epistemológicos" perante o "discurso normal" - o discurso conduzido segundo convenções consensuais - e em "sermos hermenêuticos" perante um discurso anormal - o discurso incomensurável (SANTOS, 1989 apud RORTY, p.27).

Santos discorda da posição kuhniana de Rorty relativa aos dois tipos de discurso uma vez que acredita que, para o cidadão comum, todo discurso da ciência é anormal. Embora concorde com Rorty sobre o fato de que a epistemologia, enquanto filosofia da ciência, seja um "episódio da cultura européia", afirma que ela está "longe da exaustão". O discurso da ciência só será socialmente compreensível se adotarmos, perante ele, uma atitude hermenêutica. Mas essa atitude também deverá abranger o próprio discurso epistemológico sobre a ciência, exercendo-se, assim, uma hermenêutica crítica da epistemologia (SANTOS, 1989, p.26-27). 
Essa análise deverá se voltar, antes, para a pragmática da epistemologia que se exerceu, já que, voltando-se à sua sintaxe ou semântica, permaneceríamos nos limites da própria epistemologia ${ }^{4}$.

Rorty acredita que o ponto de vista hermenêutico, além de diminuir a importância da busca da verdade, tem um caráter educativo. Para chegarmos a ser hermenêuticos temos que passar por um processo de aculturação convivendo com as descrições oferecidas pela nossa cultura. Passaremos por etapas de conformidade às normas e discursos à nossa volta. Só passando pelo discurso normal é que poderemos pretender o discurso anormal. Nesse sentido, o discurso anormal é parasita do normal, assim como a possibilidade da hermenêutica é parasita da possibilidade da epistemologia. A edificação "emprega sempre materiais fornecidos pela cultura do momento". Assim sendo, não faz sentido pretender ser hermenêutico onde a epistemologia ainda teria seu efeito, ou seja, devemos ver o discurso normal nos seus próprios motivos, e não do interior do discurso anormal (RORTY, 1988, p.283).

A posição de Rorty é holista face à sua crença no fato de que a necessidade de uma epistemologia para exercer a racionalidade decorre da idéia de que "precisamos ... ser capazes de arranjar um acordo com outros seres humanos" (RORTY, p.248). A epistemologia é uma manifestação da própria filosofia sistemática (idem, p.297). Santos, por outro lado, persiste na crença na epistemologia, mesmo aceitando a afirmação de Hegel de que ela é uma falsidade, mas é "verdadeira na sua falsidade" (SANTOS, 1989, p.27). A sua própria negação como fundamento e a manifestação de sua inviabilidade constituiria “a verdade possível e precária, mas legítima, de uma ciência sem fundamentos”. “... a epistemologia, sendo necessariamente uma ilusão, é uma ilusão necessária" (idem, p.27-28).

De fato, a epistemologia evoluiu com a própria evolução da ciência moderna. Na fase inicial (séc.

\footnotetext{
4 Se podemos concordar com Santos sobre o fato de que todo o discurso da ciência é anormal perante o cidadão comum, não poderemos deixar de concordar com Rorty (e com Kuhn) sobre dois tipos de discurso quando os analisamos face aos modelos aceites de discurso da ciência. Na linha de pensamento de Feyerabend, pode-se admitir a existência de discursos que fogem ao modelo consensual e discursos que se desenham a seu modo e partilham do fetichismo do conhecimento. Entretanto, na contínua negociação de sentido dentro da comunidade científica, pode passar-se do discurso anormal para o normal, dependendo da força de persuasão da argumentação. A exposição pública é condição do discurso. E a maneira como tal exposição é levada a efeito - ao modo do anarquismo metodológico ou ao modo da "metodologia transgressiva" (no sentido dado por Santos, de transgressão às regras publicamente consagradas) - determina sobremaneira as condições de sua aceitação. A retórica exerce, nesse sentido, uma sensibilização. A questão principal, entretanto, não é essa, mas sim a análise das implicações desses discursos pois, ao invés de submetê-los ao "tribunal da razão", deve-se avaliá-los através do "tribunal do devir histórico do homem no mundo". E nesse sentido, é forçoso concordar com Santos sobre a necessidade de ver o discurso científico na sua condição de socialização, exercendo-se sobre ele antes uma análise pragmática do que sintática ou semântica (muito embora possa-se discordar de Santos quando consideramos as três facetas como interdependentes e se refletindo mutuamente).
} 
XVII a meados do séc. XIX), a ciência procurava se consolidar como um saber privilegiado assumindo a tarefa de buscar a verdade e a objetividade e a epistemologia constituiu uma tentativa frustrada porque se propôs à investigação das causas como base de justificação social da ciência. No apogeu da ciência moderna (meados do séc. XIX até hoje), e quando ela passa a ser reconhecida socialmente pelo desenvolvimento tecnológico que proporcionou, a epistemologia pôde dispensar a investigação das causas, já que a ciência passou a justificar-se socialmente pelas suas conseqüências.

Porém, a justificação social da ciência não deve ser vista como uma relação especial entre idéias (ou palavras) e objetos, mas uma questão de prática social, uma questão de conversação. A necessidade de procurar as causas é tributária da tradição de uma filosofia sistemática que é reducionista e atomística (RORTY, 1988, p.139).

A reflexão epistemológica deve mostrar que, em processos históricos de hegemonia científica, as conseqüências são sempre as causas da ciência. Portanto, é nas conseqüências, também, que devem ser procurados os limites da justificação. Por outro lado, a agudização da crise da ciência moderna altera a natureza do problema epistemológico, deslocando o eixo de preocupações das causas para as conseqüências sociais da ciência. A reflexão epistemológica passa, então, a incidir sobre os "utilizadores" do discurso científico, constituído tanto de cientistas como de cidadãos comuns. Altera-se a finalidade da epistemologia para alcançar maior comunicação entre eles. A epistemologia assume um caráter pragmático e a hermenêutica torna-se a "pedagogia da construção da epistemologia pragmática". O desenvolvimento dessa pedagogia deve procurar o equilíbrio entre uma "hermenêutica de recuperação" e uma "hermenêutica de suspeição" para o fazer científico e epistemológico. “... o objetivo existencial da ciência [agora] está fora dela. Esse objetivo é democratizar e aprofundar a sabedoria prática, a phronesis aristotélica, o hábito de decidir bem" (SANTOS, 1989, p.29).

Rorty também aponta a hermenêutica como o caminho para a racionalidade muito embora enfatize que ela não é "tema substituto" da epistemologia - buscando, com isso, evitar identificá-la com uma procura de um quadro neutro para a pesquisa. A grande diferença entre as duas posturas é que, primeiro, Santos não desiste da idéia de verdade (embora afirme não ter uma concepção terminal de verdade ${ }^{5}$ ), já que a desconstrução hermenêutica que propõe se baseia em Bachelard: “... a epistemologia bachelardiana representa ... o máximo de consciência possível de uma concepção de ciência comprometida com a defesa da autonomia e do acesso privilegiado à verdade do conhecimento científico...” (SANTOS, 1989, p.30). Já em Rorty, a busca da verdade tem pouca

5 "Sendo a verdade, ela própria, um acontecer mais do que um acontecimento, a epistemologia pragmática não tem uma concepção terminal da verdade" (SANTOS, 1989, p. 49). 
importância, face a uma abordagem pragmática do conhecimento (RORTY, 1988, p.283). Segundo, porque Santos inclui a reflexão sobre as conseqüências sociais do conhecimento científico, coisa que Rorty se furta a discutir (e nesse sentido poderíamos afirmar que a pragmática de Santos é mais comprometida). Terceiro, porque a abordagem de Santos pressupõe, além de uma hermenêutica de suspeição (a conversação e a comensuração, em Rorty), uma hermenêutica de recuperação para olhar o discurso da ciência moderna (onde Rorty ainda vê a utilidade da epistemologia).

Os princípios hermenêuticos, sugeridos por Gadamer, devem orientar qualquer opção epistemológica para realizar a reflexão sobre a ciência, pautando, conseqüentemente, as operações a serem realizadas sobre o objeto. “... qualquer que seja a opção epistemológica sobre o que a ciência faz, a reflexão sobre a ciência que se faz não pode escapar ao círculo hermenêutico, o que significa, antes de mais, não podermos compreender qualquer das suas partes (as diferentes disciplinas científicas) sem termos alguma compreensão de como 'trabalha' o seu todo, e, viceversa, não podemos compreender a totalidade sem termos alguma compreensão de como 'trabalham' as suas partes “(SANTOS, 1989, p.11-12) ... “o todo e a parte são aqui, de algum modo, uma ilusão mecânica, pois o princípio hermenêutico é o de que a parte é tão determinada pelo todo como o todo pelas suas partes" (GADAMER, 1983, p.162 apud SANTOS, idem ibidem). Rorty, do mesmo modo, afirma, de forma holística, que "Não seremos capazes de isolar os elementos básicos, exceto na base de um conhecimento prévio da totalidade da estrutura em que estes elementos ocorrem" (RORTY, 1988, p.250).

A reflexão hermenêutica permite transformar o objeto estranho, distante e incomensurável que é a ciência, num objeto mais próximo e familiar, permitindo que, mesmo numa linguagem distinta daquela que utilizamos no dia-a-dia, possamos entender seus valores, limites e objetivos. A reflexão hermenêutica permite, assim, que a ciência nos "fale", alterando, portanto, a relação eu-coisa, característica da ciência moderna (para ele, a relação epistemológica), numa relação $e u-t u$ (a relação hermenêutica). Isso significa a tentativa de rompimento da barreira do discurso do senso comum com o discurso "anormal" - como se caracteriza, segundo o autor, todo o discurso científico produzido a partir da matriz da ciência moderna (Bacon, Descartes, Locke) ou fundado nos princípios absoluto ou a priori kantianos.

O caminho hermenêutico apontado por Rorty é o da comensurabilidade e da conversação. A comensurabilidade, no sentido de que se pode tentar alcançar um acordo racional sobre questões conflituosas. Sem a comensuração, cai-se no relativismo. A conversabilidade, no sentido em que a conversação "não pressuponha nenhuma matriz disciplinar que una os locutores, mas onde nunca se perde a esperança de acordo, ou pelo menos, de desacordo excitante e frutuoso" (RORTY, 1988, p.248-249). A diferença entre a epistemologia e a hermenêutica é que a primeira sempre 
pressupõe que se possa chegar a um acordo na crença de que possa existir um terreno comum; a racionalidade em hermenêutica, ao contrário, não pretende a existência de um patamar comum a partir do qual possa se estabelecer a conversação. "Para a epistemologia, ser racional é encontrar o devido conjunto de termos em que todas as contribuições devam ser traduzidas para que o acordo se torne possível; a conversação é inquérito implícito. Para a hermenêutica, o inquérito é conversação de rotina" (RORTY, p.249).

A preocupação de Santos com a hermenêutica se traduz em método (coisa que Rorty não faz, até porque não pretende que a hermenêutica substitua a epistemologia), através da sugestão de se realizar uma dupla ruptura epistemológica (RORTY, 1988, p.247; SANTOS, 1989).

A primeira ruptura epistemológica nos coloca a necessidade de ir contra o senso comum - para fazer ciência - para ir contra o fazer do pensamento 'conservador e fixista' característico. A segunda ruptura epistemológica, entretanto, procura integrar o senso comumà reflexão, na tentativa de evitar a excessiva racionalização das coisas e com o objetivo de 'captar' os sentidos de resistência que, ao lado da subordinação, têm espaço dentro dela.

No movimento de segunda ruptura é necessário considerar a positividade dos erros (Foucault), o papel dos preconceitos ou pré-juízos no processo de compreensão, como compreensão do nosso estar no mundo (Gadamer), a importância da inferência (Elser)e até a irracionalidade, muito mais complexa do que se pode pensar à primeira vista. O fato de que o senso comum seja visto como carregado de negatividade, ilusão, falsidade, conservadorismo, superficialidade, enviesamento, decorre de sua caracterização usualmente feita a partir da ciência. Ao contrário, o senso comum é prático e pragmático, vinculando-se às trajetórias e às experiências de vida de grupos sociais. $\mathrm{O}$ senso comum "é retórico e metafórico; não ensina, persuade" (SANTOS, 1987, apud SANTOS, 1989, p.39-40).

Se a primeira ruptura é imprescindível para constituir a ciência, mas deixa o senso comum tal como estava antes dela, a segunda ruptura permite transformá-lo e integrá-lo com base na ciência. “A dupla ruptura epistemológica é o modo operatório da hermenêutica da epistemologia. Desconstrói a ciência, inserindo-a numa totalidade que a transcende" (SANTOS, 1989, p.40-41).

Santos compartilha com Bachelard a idéia de que ciência e opinião se contrapõem e que, em ciência, tudo é construído e que só a constante vigilância epistemológica pode vencer os obstáculos que separam ciência e senso comum. Mas, para Santos, a ruptura bachelardiana interpreta o modelo de racionalidade da ciência moderna e só é compreensível dentro dele: constitui-se contra o senso comum buscando transformar a relação eu-tu em relação sujeito-objeto, subordinando o objeto ao sujeito e pressupondo como única forma de conhecimento o conhecimento científico 
baseado na objetividade. É uma epistemologia de limites, só sendo válida dentro do paradigma que 'origina, gere e resolve as crises sem ele próprio entrar em crise”' (SANTOS, p.34-35).

Contrariamente a Rorty, portanto, Santos acredita que essa epistemologia não serve para lidar com as crises paradigmáticas. Na fase inicial da crise essa epistemologia continua a ser recomendada pois é fator de ordem e estabilidade, condição que ele acredita ser necessária para pensar a próxima revolução científica. Se ela representou progresso para a racionalização do mundo, deve agora ser "relativizada no interior de uma racionalidade envolvente“. E énesse ponto que se concebe o reencontro da ciência com o senso comum: "uma vez feita a ruptura epistemológica, o ato epistemológico mais importante é a ruptura com a ruptura epistemológica” (SANTOS, 1989, p.36).

O senso comum, entretanto, só poderá ser adequadamente assimilado quando ele, e a ciência moderna, se superem a si mesmos para dar origem a uma nova forma de conhecimento. E é nesse sentido que a dupla ruptura revela sua importância, porque permite transformar tanto o senso comum como a ciência. O senso comum torna-se 'esclarecido', e a ciência, 'prudente'. Combinase, assim, "o caráter prático e prudente do senso comum com o caráter segregado e elitista da ciência ... Cria-se uma "configuração de conhecimentos que, sendo prática, não deixe de ser esclarecida e, sendo sábia, não deixe de estar democraticamente distribuída" o que é passível de acontecer, hoje, graças ao desenvolvimento tecnológico da comunicação (SANTOS, 1989, p.42).

A dupla ruptura epistemológica descontrói a ciência e insere-a numa totalidade que a trancende. Essa desconstrução sujeita-se a alguns topoi de orientação, conforme abaixo:

a) o atenuamento do desnivelamento dos discursos (discursos do senso comum/discursos eruditos);

b) a superação progressiva da dicotomia contemplação/ação, subjacente à filosofia grega e dominante na ciência moderna. “... desde Bacon e Descartes, ... a ciência moderna pretende conhecer o mundo, não para o contemplar, mas para o dominar e transformar, e neste sentido a sua racionalidade é instrumentalista". Hoje, entretanto, a verdade científica é determinada no próprio processo de produção da ciência. A valorização da práxis torna possível transformar a técnica numa dimensão da prática, e não o contrário.

c) é necessário encontrar um novo equilíbrio entre adaptação e criatividade. Como resultado do desenvolvimento tecnológico - domínio da natureza pelo homem - o poder adaptativo prepondera sobre o criativo. Um novo equilíbrio entre essas duas forças só será possível através de uma compreensão da ciência que privilegia as conseqüências, obrigando o homem a refletir sobre os custos e benefícios da produção técnica da natureza e do meio ambiente: essa prática saberá transformar a técnica.

A hermenêutica da epistemologia é, nesse sentido, crítica e sociológica, privilegiando a reflexão 
sobre a verdade social da ciência moderna como meio de questionar um conceito de verdade científica demasiado estreito, "obcecado pela sua organização metódica e pela sua certeza, e pouco ou nada sensível à desorganização e à incerteza por ele provocadas na sociedade e nos indivíduos"(SANTOS, p.43-45).

\subsection{A questão do método}

Afirma-se, freqüentemente, que a Documentação carece de um estatuto teórico consistente. De fato, o predomínio da prática fez dela, antes, um campo de opiniões e, enquanto tal, seus discursos seriam identificados prioritariamente como discursos do senso comum.

A Documentação compreende, entretanto, inúmeros subcampos de desenvolvimento desigual, razão pela qual a análise de seus discursos não poderia ser realizada de modo homogêneo. Ao lado de discursos que espelham o senso comum, há discursos que poderíamos identificar como "normais", no sentido atribuído por Kuhn e Rorty.

As afirmações de Rorty e Boaventura Santos, embora se diferenciem quanto à importância conferida às conseqüências sociais decorrentes dos vários discursos, convergem quanto à necessidade de enfocá-los de modo holístico. Realizar a distinção entre discurso normal e anormal, sob este aspecto, pode deixar de ter importância se sua análise se voltar às práticas sociais decorrentes.

Assumir um ponto de vista holístico significa, neste contexto, considerar a totalidade dos discursos produzidos pela Documentação sem privilegiar, ou suas partes, ou seu todo. A interdependência todo-parte, afirmada por Gadamer e admitida pelos dois teóricos acima, encaminha nossa análise para o conjunto dos resultados advindos das diferentes maneiras de abordar o objeto material da Documentação.

O modo operacional dessa análise não visa buscar um resultado definitivo, mas identificar parâmetros úteis ao desenvolvimento das nossas atividades de representação. Nesse sentido deveremos levar a discussão muito mais como um "prosseguimento da conversação" e não como procura da comensurabilidade, no sentido de Rorty. Não poderemos buscar, portanto, que os discursos mais elaborados da Documentação pautem os discursos onde domina a opinião.

De fato, a noção de verdade acerca da realidade é sempre "acerca da realidade-sob-certadescrição" (RORTY, 1988, p.292) e "a verdade do conhecimento reside na sua adequação concreta à prática que visa construir (SANTOS, 1989, p.47). As conseqüências têm que ser desejadas, e por isso mesmo antecipadas, o que desloca o centro da reflexão não para o conhecimento feito, 
mas para o conhecer enquanto prática social (idem ibidem, p.49). A análise dos discursos documentários deve se voltar, pois, à verificação de seus resultados enquanto instrumento para o conhecimento.

O projeto de racionalidade de Rorty - que se assemelha, neste aspecto, ao de Santos - solicita que o discurso normal não seja fator de bloqueio do fluxo de conversação oferecendo seu vocabulário canônico para a discussão (p.298). A citação de Sellars, feita e assumida pelo autor ilustra o estatuto dessa conversação no processo de conhecimento: "ao caracterizarmos um episódio ou estado como sendo de conhecer, não estamos a dar uma descrição empírica desse episódio ou estado; estamos a colocá-lo no espaço lógico das razões, da justificação e da capacidade para justificarmos aquilo que dizemos" (SELLARS, 1963 apud RORTY, 1989, p.300).

A relutância de Rorty em falar em método deve-se, sob nosso ponto de vista, a um receio quanto ao cerceamento da conversação, uma vez que essa é uma característica marcante do positivismo. O método, porém, têm pautado tanto as discussões que romperam radicalmente com o positivismo (fenomenologia, por exemplo), como também as discussões que mantiveram o núcleo central do paradigma positivista (como o construtivismo racionalista). O primeiro, para garantir a consistência do conhecimento científico frente ao senso comum; o segundo, para que o reconhecimento da precariedade da verdade científica - mera construção mental - não fizesse com que o conhecimento científico caísse no irracionalismo (SANTOS, 1989, p.73-74).

O método permite encaminhar o exercício da hermenêutica crítica ${ }^{6}$ através da suspeição e da recuperação, consubstanciadas através da dupla ruptura epistemológica. Sua consecução visando ao estabelecimento da 'conversação' requer a superação do paradigma positivista ${ }^{7}$, deslocando a relação sujeito-objeto para a relação eu-tu.

O exercício de uma hermenêutica crítica relacionada aos discursos da Documentação remete, pois, mais do que à análise dos distintos instrumentos de representação documentária, à relação entre tais instrumentos e suas resultantes práticas, ou seja, sua adequação, utilidade para promover a representação,

6 A referência ao método feita por Santos na introdução de seu texto é uma epígrafe de Descartes: “O meu intento não é ensinar aqui o método que cada qual deve seguir para bem conduzir a sua razão, mas somente mostrar de que maneira procurei conduzir a minha".

7 Santos sintetiza os pressupostos do positivismo: a "realidade enquanto dotada de exterioridade; o conhecimento como representação do real; a aversão à metafísica e o caráter parasitário da filosofia em relação à ciência; a dualidade entre fatos e valores com a implicação de que o conhecimento empírico é logicamente discrepante de objetos morais ou da observação de regras éticas; a noção de "unidade da ciência", nos termos da qual as ciências sociais e as ciências naturais partilham a mesma fundamentação lógica e até metodológica". O positivismo lógico, por sua vez, caracteriza-se pela "ênfase na unificação da ciência, pelo modelo de explicação hipotético-dedutivo e pelo papel central da linguagem científica na construção do rigor e da universalidade do conhecimento científico" (SANTOS, 1989, p.52). 
organização e transferência da informação. Dito de outro modo, para promover o conhecimento.

Se analisarmos o debate metodológico da ciência moderna, desde Bacon e Descartes até hoje, veremos que ele tem se voltado à questão da criação do conhecimento, procurando saber qual é a participação do sujeito e do objeto, da teoria e dos fatos, dos conceitos e da observação. Correntes objetivistas, naturalistas e empiristas centram seu foco no objeto, fatos e na observação, enquanto correntes racionalistas, idealistas e subjetivistas privilegiam o sujeito, a teoria, os conceitos. O discurso metodológico dominante procura uma via intermediária (que congrega representantes de ambas as correntes acima) e que advoga à teoria o comando sobre todo o processo de criação científica. A teoria constitui uma forma específica de conceptualizar a realidade e de transformá-la em objetos teóricos, para poder, então, formular hipóteses e validá-las. Estabelece-se, portanto, uma diferença radical entre objetos de conhecimento e seus referentes na realidade material, embora admita-se sua existência e uma correspondência entre ambos.

Diante desse quadro, não faz sentido a busca de uma verdade absoluta ou uma cópia fiel da realidade e o estudo da representação no âmbito documentário deve considerar que toda a representação é uma construção. Não se trata, pois, de discutir se ela é mais, ou menos, fidedigna, mas se é adequada e suficiente para cumprir objetivos específicos de transferência da informação. Afirma Santos que o conhecimento é falível e a verdade aproximada e provisória, porém nem todo conhecimento é igualmente falível e nem a separação fato de conhecimento/mundo material impede a existência de relações entre eles. São essas relações que contemplam uma dimensão prática do conhecimento, através da sua atuação de transformação do mundo material. No âmbito documentário a relação fato de conhecimento/mundo material é determinada pelo modo como se encaminha a análise, em função e no limite de objetivos. A verdade na relação fato de conhecimento/ mundo material é sobremodalizada por um ponto de vista, adequado e útil nos limites dos objetivos funcionais de representação. A investigação dirige-se à verificação da relação função pressuposta ou desejada/resultados, passando pela análise dos meios utilizados para sua consecução.

Pressuposto moderno, a separação objetos teóricos/objetos empíricos pautou, durante muito tempo, as análises. A existência de uma ruptura entre objetos teóricos e objetos empíricos não permite, entretanto, 'comparar' o conhecimento teórico com a realidade não conceptualizada o que implica, conseqüentemente, questionar a idéia de um controle externo da veracidade da teoria. Se esse controle não pode residir na adequação prática (esta é conseqüência da verdade, e não sua causa) conforme a posição dominante, “ela só pode ser definida por referência aos critérios internos de uma dada teoria" o que implica que não é possível comparar proposições decorrentes de paradigmas diferentes (SANTOS, 1989, p.71-73). Como decorrência dessa concepção pragmática de verdade, todas as questões acima não poderão ser resolvidas “fora de um quadro prático de intervenção na realidade (SANTOS, 1989, p.73). 
Não basta, portanto (seguindo o paradigma moderno), estabelecer o objeto teórico da Documentação, já que as análises se restringirão à validação a partir do modelo teórico adotado. Romper a barreira entre objeto teórico/objeto empírico significa verificar, a partir das funções das representações documentárias, como elas funcionam para alcançar os objetivos delimitados. A utilização de um conceito pragmático de verdade supõe, implicitamente, que uma representação documentária seja tratada como uma hipótese de organização funcional. É preciso cautela na análise dos discursos sobre a representação documentária já que, muitas vezes, a preocupação com o rigor metodológico pode mascarar os resultados, circunscritos que estão aos limites da teoria utilizada ${ }^{8}$.

Embora a metodologia racionalista tenha significado um avanço no aprofundamento da consciência científica moderna, ela deve ser criticada mais pelo que deixou de avançar, ou seja, porque ela não aceitou todas as implicações de uma concepção do conhecimento científico como construção teórica desenvolvida num determinado contexto social. A metodologia racionalista, melhor do que qualquer outra, permite estabelecer a primeira ruptura epistemológica, sem a qual a segunda não poderia ter lugar. Porém, se é aí que ela apresenta suas maiores potencialidades, é aí também que mostra suas limitações, "porque não concebe essa ruptura como primeira mas sim como única" (SANTOS, 1989, p.76). Não significa, pois, abandonar os resultados das análises realizadas a partir do modelo, porém relativizar seus resultados. De fato, a ruptura concebida pelo construtivismo racionalista acaba por inviabilizar ou tornar impensável a segunda ruptura. Na realidade, "se a primeira torna possível a teoria crítica, só a segunda ruptura torna possível que a crítica seja prática". A concretização de uma teoria prática deve ser feita a partir de um critério: "o da superação da distinção entre ciência e senso comum e da transformação de ambos numa nova forma de conhecimento, simultaneamente mais reflexivo e mais prático, mas democrático e mais emancipador do que qualquer deles em separado" (idem ibidem, p.76-77).

Na realidade, todo conhecimento é contextual, e o conhecimento científico, duplamente contextualizado: pela comunidade científica e pela sociedade. O conhecimento é simultaneamente prática científica e prática social, dimensões que não podem ser separadas (idem ibidem, p.77), o que remete à necessidade de reformular questões relativas à primeira ruptura, que resumimos abaixo:

a) a distinção entre proposições teóricas e proposições observacionais não tem nada de substantivo, é meramente posicional, derivando da posição dos termos no interior do contexto social e cultural da ciência. Isso implica a transformação do observável em não observável (primeira

8 A argumentação de Santos permite confirmar as suspeitas que levantamos acima relacionadas à temeridade, de Rorty, em propor um método, sob pena de limitar as avaliações ao âmbito do modelo adotado. 
ruptura) e a transformação do não observável em observável (segunda ruptura);

b) a questão da reflexividade: toda ciência é interpretativa, estando sempre subordinada à avaliação do sentido da interpretação. "Sem o estorvo do sentido ... a própria atividade científica [deixa] de ter sentido" (SANTOS, 1989, p.90).

c) "O que em uma dada investigação é interpretação ou é explicação causal ou regularidade depende do nível a que deve ser focalizado o sentido do objeto de estudo" (idem ibidem, p.90). Há objetos que se relacionam externa e contingentemente, e aí, não se coloca o problema de sua emergência ou desagregação. Porém, quando os objetos se relacionam interna e necessariamente, como nas estruturas, a explicação de um objeto pressupõe que ele seja previamente localizado no estrato que lhe dá sentido. "As descrições da realidade são sempre prescrições e, também ... proscrições. A verdade é normativa e só existe enquanto luta de verdades" (idem ibidem, p.95).

d) "Se a verdade é a luta de verdades, é também o consenso que permite essa luta"... No claroescuro de lutas e consensos, mais do que verificar ou falsificar teorias, o nosso trabalho metodológico consiste em avaliar teorias... As classificações não são as marcas que imprimimos nelas a fogo. São olhares que lhes lançamos do ponto móvel em que nos encontramos, um ponto situado entre as teorias e as práticas sociais que elas convocam"...”A prática é assim, como queria James (1969, p.37), a única força vidente que nos permite avaliar as teorias e manter uma relação cordial com os fatos"'(SANTOS, 1989, p.95-96). A concepção pragmática da verdade permite, pois, romper com a circularidade da teoria.

e) A verdade científica é de natureza retórica. Os métodos e as técnicas são argumentos quase lógicos ou argumentos sobre a estrutura da realidade. "O valor que serve de premissa à argumentação que eles desencadeiam é a verdade: ... aquilo que se pretende apresentar como incontroverso. Mas enquanto premissa da argumentação científica, a verdade é uma moldura, um valor vazio...". (idem ibidem, p.101).

f) A distinção entre linguagem da ciência e linguagem vulgar deve ser atenuada, confirmando-se o papel da analogia e da metáfora na inovação e na extensão do pensamento científico. A linguagem técnica desempenha um papel importante na primeira ruptura... enquanto a linguagem metafórica é imprescindível para a segunda..." (idem ibidem, p.116).

g) A ciência não pode deixar de lado a emoção, mas deve promover "uma interação mais profunda e tolerante entre processos cognitivos e não cognitivos, entre ciência e emoção" (idem ibidem, p.119).

Como decorrência, a análise dos discursos da Documentação altera-se profundamente.

\subsection{Os paradigmas nas ciências e a Documentação}

Para uma discussão sobre o modo como a Documentação se coloca frente aos paradigmas acima identificados é determinante, verificar, já de início, seu estatuto teórico. É significativo verificar que 
a Documentação não tem uma definição clara de seu objeto formal. A natureza 'aplicada' da Documentação, embora possa justificar a existência de discursos voltados à descrição de atividades e técnicas de tratamento que se reproduzem sem acréscimos substanciais nos seus manuais, não justifica a inexistência de reflexões sobre a motivação que a caracteriza como tal.

Essa situação se reflete, de imediato, nos seus resultados, como pode se verificar no exemplo: se uma das funções da Documentaçãoéa divulgação de informações, onde está oelo que permite inserir os produtos documentários na cadeia de comunicação? De fato, a abordagem comunicacional daDocumentaçãoémuito rudimentar, pois a divulgação exige, primeiro, a identificação das características e conseqüências do ato documentário. Estando quase ausente a discussão sobre sua inserção nos processos comunicacionais, a utilizaçãodas técnicas einstrumentos derepresentação preconizadaspelos manuais pode tornar-semeramente uma ação repetitiva. A açãode "representar" documentariamenterestringe-sea mecanismos de reprodução. Conseqüentemente, fica difícil sugerir a aprendizagem dos processos de representação, como tornam-se dificeis quaisquer formalizações-como o comprovou o uso da Informática nesse processo.

A adoção de uma atitude hermenêutica, no caso da Documentação, portanto, não pode prescindir de um primeiro momento de ruptura, de forma a construir um objeto formal contra o senso comum, assumindo uma atitude de suspeição frente às opiniões. A construção do seu objeto formal requer a revisão das opiniões, procurando-se identificar as degenerações provocadas no exercício das funções que, muitas vezes de forma retórica (no sentido vulgar do termo), haviam sido postuladas de início.

Essa construção deve passar por momentos de recuperação visando identificar bolsões de pensamento criativo no interior da prática. De fato, é essa a prática a ser resgatada para que a técnica torne-se uma verdadeira dimensão da prática. A Documentação tem inúmeros exemplos de resultados satisfatórios frutos de um pensamento intuitivo que uma atitude hermenêutica de recuperação poderá resgatar.

Quanto à segunda ruptura epistemológica, ela deverá permitir recuperar o que a fidelidade ao modelo racional não deixou aflorar. Essa atitude deverá permear a análise de inúmeras contribuições construidas segundo parâmetros modernos, desde as colocações de Ranganathan, na década de 30, sobre a distinção de planos de representação de assuntos - plano das idéias, plano verbal e plano notacional -, passando pela importância excessiva conferida ao conhecimento científico pautado no modelo das ciências puras ${ }^{9}$ (Gardin) e pelas formulações essencialmente

9 Boaventura Santos enfatiza que a superioridade das ciências naturais sobre as sociais caracteriza o pensamento da filosofia positivista. Parte-se, normalmente, da precariedade do estatuto epistemológico das ciências sociais em relação ao das ciências naturais. Invertendo os termos da questão e partindo da precariedade do estatuto epistemológico das ciências naturais (o que implica uma ruptura total com a filosofia positivista), Santos sugere perguntar se as ciências naturais são iguais ou diferentes das ciências sociais. Para o autor, as ciências naturais, embora continuem diferentes das ciências sociais delas se aproximam cada vez mais, considerando os avanços científico e tecnológico (SANTOS, 1989, p.51-52). 
calcadas na lógica subjacentes às normas de construção de tesauros.

Em resumo, as reflexões de Rorty e Santos permitem verificar que as questões que contextualizam nossa pesquisa, explicitadas no início do trabalho, são sintomáticas da "crise de crescimento" em que se encontra a Documentação, que, entretanto, não podem deixar de ser enfrentadas sem considerar os novos problemas advindos de uma crise de degenerescência da ciência de um modo geral. O caso da Documentação, que poderia ser considerado paradoxal, revela, na realidade, seu incipiente desenvolvimento teórico, o que nos impõe uma dura tarefa.

Antes de examinarmos os discursos da Documentação sobre a representação procuraremos identificar como as abordagens da Filosofia, Lingüística e da Semiótica abordam a questão da representação. Acreditamos que esse levantamento poderá nos fornecer elementos para melhor avaliar como o conceito vem sendo utilizado pelos vários discursos da Documentação, bem como ele contempla a necessidade operacional para a transmissão de informações, ou seja, como permite que ele se realize enquanto prática social.

\subsection{Acerca do conceito de representação}

A abordagem da representação não é feita de forma homogênea pela literatura filosófica, sociológica, semiótica e lingüística. No interior destas disciplinas, várias vertentes contemplam pontos de vista diferentes.

\subsubsection{O conceito de representação na Filosofia segundo abordagem de Rorty e de Boaventura Santos}

A busca de tais referências em Rorty e Boaventura Santos, além de permitir reunir subsídios para a construção de um conceito de representação em Documentação, tem como objetivo identificar os princípios a partir dos quais as linguagens documentárias têm sido construidas, bem como quais são suas conseqüências na representação e na sua recepção.

A visão de representação em Rorty tem como pressuposto a idéia de verdade múltipla e de diversidade, noções radicalmente opostas ao que acreditamos serem as opções fundantes dos sistemas de classificação bibliográfica universa ${ }^{10}$, , primeiras linguagens documentárias formalmente

10 Embora datem do final do séc. XIX - início do séc. XX, os Sistemas de Classificação Bibliográfica Universais ainda continuam sendo utilizados pelas nossas bibliotecas. 
estabelecidas, e de muitas outras propostas posteriores. Se tais opções de construção podem ser justificadas relativamente aos sistemas de classificação, só o são a partir de sua localização no contexto histórico e geográfico, não tendo sentido extemporâneo. As reflexões de Rorty e Boaventura Santos nos auxiliam a confirmar que a pretensão de linguagens documentárias universais está equivocada e que, muito embora o atributo “universal" não seja categoricamente pretendido por todas elas, esse paradigma continua subjacente a muitas dessas construções. Do mesmo modo, a prática a partir de sua utilização.

Não é a proposta moral e política de Rorty que nos interessa assimilar como contribuição para a nossa discussão - seu pragmatismo extremo acaba isentando-se do comprometimento social, o que questionamos. O que nos interessa é verificar o que a crença em substâncias e em essências, bem como a crença em uma verdade única a ser buscada, oposta à idéia pragmatista, significou historicamente e como ela se refletiu nas construções sobre o conhecimento e sua organização. É verdade que o abandono da noção de verdade como correspondência não é exclusiva do autor. Filósofos como Nietzsche, Foucault, Derrida, por exemplo, também repudiaram essa noção. Rorty significa, talvez, uma referência extrema a partir da qual possamos balizar melhor nossa discussão.

Para não nos restringirmos ao seu pragmatismo e utilitarismo e para estabelecermos um outro contraponto, buscamos também referências em Boaventura Santos (cujas idéias também estão presentes no início do capítulo) - uma relativização do relativismo de Rorty-e um ponto de vista de caráter mais sociológico.

Para a Filosofia, a representação é geralmente vista na sua relação com o real. Ao explorarmos essa faceta procuramos encontrar, particularmente, subsídios para compreender qual a visão de mundo subjacente à construção das linguagens documentárias e, conseqüentemente, qual é a concepção de representação correspondente.

A compreensão da noção de representação em Rorty e Boaventura Santos não parte de propósitos semelhantes. A abordagem de Rorty é mais filosófica, pondo em questão a forma de conhecimento; o ponto de vista de Boaventura tem um caráter mais sociológico e pedagógico, no sentido em que pretende propor um método para analisar as formas do conhecimento. As aproximações que realizamos partem da inferência dos seus pontos em comum e das suas discordâncias, mas tem em vista identificar, em ambos, a noção de representação explícita ou implicitamente colocada.

Como Boaventura Santos, Rorty rompe com a tradição cartesiana e kantiana quando enfoca a noção de conhecimento questionando o estatuto das representações enquanto tentativas de cópias da realidade. Descartes pretendia "tornar o mundo seguro para as idéias claras e distintas" e Kant "de o tornar seguro para as verdades sintéticas a priori” (RORTY, 1988, p.135). A noção de 
conhecimento como exatidão da representação é oriunda da filosofia natural que concebe a mente como um grande espelho que contém várias representações. É essa a idéia básica que fundamenta um percurso de procura de métodos para se chegar ao conhecimento, que se caracteriza por uma espécie de tentativa de polimento do espelho para que a verdade seja alcançada.

O pensamento de Rorty se desenvolve a partir do segundo Wittgenstein - que procurou desconstruir tais imagens - e é complementada por Heidegger - que trabalha a consciência da origem da imagética especular redescrevendo a história da filosofia. A perspectiva social da história dessa imagética ocular Rorty encontra em Dewey, para quem hoje, a cultura não é mais dominada pelo “ideal da cognição mas pelo da elevação estética” (RORTY, 1988, p.21-22).

Rorty define-se como partidário de um behaviorismo epistemológico, uma espécie de holismo que, segundo ele, não requer suportes metafísicos idealistas. A filosofia holista não tem como preocupação a busca da certezas. A compreensão das regras de um jogo de linguagem permite compreender o porque de se "efetuarem os lances dentro daquele jogo", sem a necessidade de apoio nas tradicionais distinções kantianas. A racionalidade e a autoridade epistêmica explicam-se "por referência ao que a sociedade permite afirmar" (RORTY, 1988, p.142). O conhecimento é mais uma questão de conversação e de prática social do que uma tentativa para espelhar a natureza (idem ibidem, p.139). Essa visão pragmática não postula uma divisão entre o senso comum e ciência e não aceita considerar os conceitos a priori, idéias inatas e dados sensoriais como premissas a partir das quais se possa inferir o conhecimento de outras entidades.

Santos revela posição semelhante ao questionar as tentativas de fundar dogmaticamente a ciência nos princípios do absoluto ou do a priori fornecidos pela filosofia (Descartes, Kant, Hegel e Husserl) propondo que ela seja vista enquanto prática social de conhecimento, "uma tarefa que se vai cumprindo em diálogo com o mundo ..."(SANTOS, 1989, p.13). A prática do conhecimento acaba por "coisificar" a sociedade, transformando-a em múltiplos objetos teóricos e só o reconhecimento social desse mesmo conhecimento permitiria a apropriação dessa objetivação, ou seja, permitiria que o conhecimento se tornasse subjetivável: "os objetos teóricos se transformam nos objetivos sociais dos sujeitos sociais que podem investir no conhecimento científico-social e, portanto, apropriar-se dele" (SANTOS, p.14).

De fato, durante muito tempo, a noção de representação esteve associada à de explicação adequada aos fatos. De Descartes à Kant, a filosofia (e a epistemologia) se afirmam perante a ciência; o positivismo lógico (Círculo de Viena) representou o climax dessa procura quando viu na ciência o aparelho privilegiado de representação do mundo e postulou uma coincidência entre linguagem unívoca e experiência. Dentro, porém, do próprio Círculo de Viena, Wittgenstein realizou sua autocrítica e lutou contra a tentação de procurar na linguagem (no jogo da linguagem) o fundamento 
absoluto do conhecimento. Feyerabend e Kuhn, por outro lado, contribuem para abalar o modelo de racionalidade da ciência moderna através, respectivamente, da proposta do anarquismo metodológico e da identificação de crises, inconsistências e contradições dentro da própria ciência.

De fato, a crise de degenerescência pragmática desencadeada, passa a colocar em causa a própria inteligibilidade do real (e com ela seus instrumentos metodológicos e conceituais), acabando por transformar a própria consideração do privilégio do conhecimento científico em uma prática de saber entre outras.

A visão de representação, conseqüentemente, deixa de ser buscada a partir de um fundamento. Rorty chega a se perguntar, inclusive, se realmente faria sentido sugerir que o conhecimento possui, de fato, algum fundamento, observando que qualquer afirmação sempre é feita 'por referência ao que já aceitamos, inexistindo forma através da qual pudéssemos nos colocar nossas convicções e de nossa linguagem (RORTY, 1988, p.145). Se não existe uma "matriz neutra permanente dentro da qual são decretados os dramas do inquérito e da história ... a crítica da nossa cultura apenas pode ser fragmentária e parcial - nunca "por referência a padrões eternos" (idem, p.145). É por isso que, para o autor, a epistemologia é a filosofia das representações privilegiadas.

Como Quine e Sellars - representantes da filosofia analítica - rejeita a noção kantiana de "duas espécies de representações”: “as intuições ‘dadas' a uma faculdade e os conceitos (ou significados) 'dados' a uma outra, porque eles reduziriam "normas, regras e justificações a fatos, generalizações e explicações" (idem, p.146). Para ele, como para Quine, “o conhecimento não é semelhante a uma estrutura arquitetônica, mas a um campo de força", não existindo asserções imunes à revisão - o que caracteriza uma abordagem holística do conhecimento . Rorty também apóia o ataque de Sellars ao "mito do dado" e o ataque de Quine à "distinção entre linguagem e fato, reivindicando que "nenhuma 'descrição da natureza do conhecimento' pode assentar numa teoria de representações que se baseie em relações privilegiadas com a realidade" (idem, p.147).

Esse questionamento relativo à separação sujeito/mundo também se coloca relativamente à filosofia da linguagem. Rorty questiona a idéia de que o entendimento de como a linguagem funciona permitiria entender como é que a “'linguagem se liga ao mundo', e, por conseguinte, como são passíveis a verdade e o conhecimento" (RORTY, 1988, p.209). Essa idéia revelaria que a filosofia da linguagem contemporânea faz uma “vaga associação de 'linguagem' com o 'a priori’ kantiano (p.209).

No universo da filosofia da linguagem, Rorty mostra que a teoria da referência seria a manifestação de uma ânsia em descobrir como as palavras se relacionam com o mundo. Porém, uma noção de conhecimento como montagem de representações, deveria ser substituída por uma concepção pragmática do conhecimento que eliminasse "o contraste grego entre contemplação e ação, 
entre representar o mundo e fazer-lhe frente". As tentativas de explicar a "racionalidade e objetividade nos termos das condições para uma representação exata é um esforço auto-ilusório para eternizar o discurso normal do momento" (idem, p.20-21). Isso representaria um desejo de encontrar 'fundamentos' a que nos pudéssemos ligar, quadros para além dos quais não pudéssemos nos perder ou um "desejo de confrontação e constrangimento (idem, p.247).

Se a noção de representação exata vinculava-se com processos básicos, privilegiados, fundamentais, a ausência dessa noção impõe considerar a prática como guia para seleção. "Não seremos capazes de isolar os elementos básicos, exceto na base de um conhecimento prévio da totalidade da estrutura em que estes elementos ocorrem. Por conseguinte, não seremos capazes de substituir a noção de "representação exata" (elemento-por-elemento) pela de realização bem sucedida de uma prática. A nossa escolha dos elementos será ditada pela nossa compreensão da prática, em vez de ser "legitimada" por uma "reconstrução racional" a partir dos elementos (idem, p.250).

Essa filosofia 'edificante' privilegia antes a conversação do que a procura pela verdade ou pela comensuração e olha de modo bifocal o discurso científico normal, desconfiando de verdades objetivas e identificando o ato de conhecer não a partir de sua descrição empírica, mas situandoo "no "espaço lógico das razões, da justificação e da capacidade para justificarmos aquilo que dizemos” (SELLARS, apud RORTY, 1988, p.300).

A representação para Rorty, está estritamente vinculada à sua justificação, sendo sua legitimação sempre temporária, local e variável. Essa, talvez, seja a maior contribuição do pensamento de Rorty para a abordagem das linguagens documentárias. As representações são sempre hipóteses válidas circunstancialmente e justificadas à base de crenças e convicções particulares, o que leva a questionar as propostas que se pretendem universais, pois não há como chegar a descrições únicas da realidade.

A concepção de representação subjacente à proposta de Santos, sob a ótica sociológica - coincide, em muitos pontos, com a de Rorty. Também para ele o conhecimento científico deve ser intersubjetivo e tolerante, mais edificante e formativo do que informativo, envolvido emocionalmente na ampliação e aprofundamento da 'conversação da humanidade', como o concebem Dewey e Rorty (SANTOS, 1989, p.118).

A revisão da reflexão epistemológica relativa ao final do séc. XIX até os dias de hoje realizada por Santos mostra que "as posições começaram por oscilar entre uma filosofia da ciência, buscando fora dela o fundamento do conhecimento certo e objetivo" - quando ele cita a crítica de Adorno à Husserl, "e uma filosofia científica das ciências, distinguindo nesta entre o contingente e o necessário e fazendo assentar neste último a garantia da verdade do conhecimento científico" - que ele critica 
por ter colocado o processo científico dentro de uma camisa de força. As reflexões avançaram para o campo da prática - quando a ciência já havia se imposto socialmente - quando cientistas e não-filósofos produziram reflexões sobre o processo de produção do conhecimento, apresentando soluções ad hoc sem, necessariamente, filiar-se às correntes determinadas de pensamento. A partir daí Santos vê uma "seqüência lógica entre o construtivismo de Bachelard, o convencioalismo de Kuhn e o anarquismo metodológico de Feyerabend"' (SANTOS, 1989, p.25-26).

As críticas ao behaviorismo de Rorty são inúmeras. Ernest Gelnner, por exemplo, que também rejeita as idéias cartesianas e kantianas, é um weberiano que acredita que "se duas verdades são contraditórias, não podem ambas ser verdadeiras" (GELLNER, 1994, p.33). Gellner crê em universais enquanto corolários da diversidade. Para Renato Lessa, "o relativista é um sujeito ubíqüo: habitante simultâneo de muitos mundos possíveis, rejeita a possibilidade de estabelecer critérios de avaliação que impõem ao mundo ordenamentos e precedências". No limite, "o relativismo é uma forma particular de definição de universais" (LESSA, 1994, p.42). Os universais seriam, já para Demócrito, uma "forma humanamente tangível de produção de estabilidade" (p.44). Bento Prado Jr. enfatiza a alienação do relativismo de Rorty que, ao recusar o valor pragmático de uma Teoria Social, "deixa escapar, ou não percebe, por sob a diversidade local das formas políticas e culturais (por voluntário etnocentrismo), ... a unidade global dentro da qual elas estão combinadas, e as carrega todas num único movimento"( PRADO JR. 1994, p.84). Para este autor, "a economia globalizada ignora as fronteiras culturais e governa as diferentes Lebenformen"... e "um discípulo de Dewey” deveria “abrir-se para essa dimensão da experiência contemporânea” (p.84).

As contribuições precedentes contribuem à nossa discussão no sentido de mostrar que a Documentação trabalha, na maior parte das vezes, a partir de uma concepção de representação substancialista e seguindo um modelo que pressupõe, mesmo que de forma implícita, a possibilidade de reprodução da realidade. A proposta de Santos, embora menos explicitamente colocada, salienta a relativização quando propõe o abandono das formas dogmáticas de conhecimento, mostrando, ao mesmo tempo, que só o reconhecimento social permite transformar a 'objetivação' em algo 'subjetivável (ou seja, a condição para a apropriação das representações documentárias está na dependência de se estabelecê-la como uma prática social). A proposta de Rorty é mais radical, já que sua concepção pragmática do conhecimento exclui qualquer possibilidade de montagem de representações. Levando ao extremo essa afirmação, a própria noção de representação entraria em colapso.

A apropriação que nos permitimos realizar, até o momento, não é tão radical, já que acreditamos na necessidade de construir uma linguagem específica para a veiculação de informações sintéticas (um requisito econômico: de forma potencializada, veja-se o resultado das recuperações via ferramentas de acesso sintáticas, na Internet). Se ela não compartilha da virtualidade da linguagem 
natural, sua estruturação exige pontos de partida que utilizem a hierarquia (e os substantivos) como meio de alcançar a estrutura elementar de significação. Isso não significa identificá-los, necessariamente, à substâncias.

A principal contribuição de Rorty, para o nosso trabalho, está na ênfase que ele dá à multiplicidade interpretativa, deslocando das 'essências' para a 'utilidade' o eixo de referência para as construções das representações. Vê-se que o autor, embora rejeite critérios de ordenamento, acaba por colocar o uso como precedência. É a partir de Boaventura Santos, entretanto, que poderemos entender melhor a importância do critério social para a definição de utilidade.

\subsubsection{A abordagem lingüística da representação}

Na atualidade, e desde Saussure, a língua é vista como fundamentalmente um instrumento de comunicação. Sob esse aspecto, a abordagem prioritária da língua volta-se ao seu papel social. Diferentemente da filosofia, o enfoque privilegiado da língua pela vertente estruturalista não se associa à relação objeto/representação ou seja, não interessa discutir a representação fora do universo da linguagem. Essa abordagem delineia um modo particular de analisar a questão da representação.

Do ponto de vista histórico, a centralidade da idéia de representação como função principal da língua vigorou por muito tempo. Para os gramáticos de Port Royal (1660), a função da língua é a representação do pensamento. Segundo Lancelot e Arnauld, autores da Grammaire générale et raisonnée - a Gramática de Port Royal - a palavra é espelho, comportando uma analogia interna com o conteúdo externo que veicula. A palavra é uma espécie de "quadro" de "imitação" do pensamento. O poder representativo do pensamento não se encontra exatamente na materialidade da palavra, mas na sua organização no enunciado. A função fundamental da língua é a comunicação dos pensamentos. A fala, para permitir essa comunicação, deve constituir uma imagem, um quadro de pensamento, exigindo que as estruturas gramaticais sejam como cópia das estruturas intelectuais. Sob esse aspecto, a língua é um sistema imutável utilizado para representar o pensamento. Conciliamse, portanto, as funções de comunicação e representação, sendo esta última um meio da primeira.

Os comparatistas colocam em dúvida a conciliação entre as funções de comunicação e representação. A economia na comunicação teria como conseqüência a erosão da língua. Línguas mais evoluídas satisfazem cada vez mais às necessidades de comunicação mas não podem ter a pretensão de adequação às estruturas do pensamento, perdendo, portanto, a função de representá-lo.

A lingüística histórica do século XIX altera tal situação ao colocar que a alteração das línguas não 
se deve apenas à vontade dos homens e que as mudanças lingüísticas são irregulares, respeitando a organização interna de cada língua. A gramática comparada deixa de lado a preocupação com a relação língua/pensamento para concentrar-se no estudo comparativo das línguas. O declínio das línguas no curso da história é atribuído ao homem, que trata a língua apenas como um meio, mero instrumento de comunicação cujo emprego deve tornar-se cada vez mais cômodo e econômico. As leis fonéticas do menor esforço sacrificariam a organização gramatical em prol da economia na comunicação (DUCROT \& TODOROV, 1988, p.22).

Na pré-história das línguas elas não eram um meio, mas um fim, moldadas para representar o espírito humano. Schleicher (1848), por exemplo, afirmava que as línguas teriam passado por vários estágios de desenvolvimento, mas só com as línguas flexionais o espírito estaria verdadeiramente representado, como unidade do dado empírico e das formas a priori no ato de pensamento, através da unidade do radical e das marcas gramaticais na palavra, cimentada pelas regras morfológicas. Mas tal estado de perfeição da língua indo-européia, considerada línguamãe, já havia sido destruído na antiguidade clássica quando a língua, colocada à serviço da comunicação, começou o processo de destruição de sua própria organização.

Os neogramáticos, na segunda metade do séc. XIX, tentaram introduzir princípios positivistas na Lingüística Histórica, procurando as causas de suas mudanças: causas de ordem articulatória, de ordem fisiológica e causas fundadas na associação de idéias, de ordem psicológica (agrupamentos, criação de novas palavras ou frases.

A superação da Lingüística Histórica é obra de Saussure, para quem a linguagem é fundamentalmente (e não por acidente ou degeneração) um instrumento de comunicação. Segundo E. Lopes, até Saussure, "a lingüística foi atomista, dedicando-se a estudar, de um ponto de vista genético e substancialista, um punhado de termos-objetos, tomando-os em separado, um por um" (LOPES, 1997, p.15). Saussure coloca em dúvida a tese comparatista de desorganização progressiva das línguas dada na atividade de comunicação, como também não se encontra nele a idéia de que a língua deva representar uma estrutura de pensamento que existisse independentemente de qualquer 'enformação' lingüística, quer seja ao modo dos comparatistas, para quem a representação é função básica da língua, quer à maneira de Port-Royal, como meio de comunicação (DUCROT \& TODOROV, 1988, p.26).

A tese do arbitrário lingüístico de Saussure considera que o pensamento, antes da língua, é uma "massa amorfa", uma "nebulosa". Saussure refuta, portanto, a idéia dos gramáticos gerais sobre a existência de uma lógica do pensamento que a língua deve imitar ou representar, bem como a noção dos comparatistas de que a unidade do radical e dos elementos gramaticais na palavra representam a unidade do ato intelectual que submete a experiência às formas a priori do espírito. 
As formas de organização das línguas não constituem, para Saussure, um efeito de uma função anterior à função de comunicação: "a língua não pode ter outra função salvo a de comunicação" (DUCROT \& TODOROV, p.25-26).

Ao argumento baseado na função da linguagem acresce-se aquele que vê, no desenvolvimento da atividade lingüística não a causa de sua degeneração, mas ao contrário, de sua evolução. A criação analógica constituiria um dos mecanismos fundamentais da sua ampliação e enriquecimento. As funções da linguagem, bem como seu emprego, não colocam em perigo a organização mesma da língua. É essa organização, o sistema, é que é determinante para o entendimento de cada um de seus elementos. Os elementos lingüísticos não têm realidade independentemente do todo.

O caráter de ordem e regularidade da língua parte da idéia de que "o conhecimento dos elementos lingüístico não é dado, e que ninguém poderia ler diretamente na experiência quais são os elementos postos em jogo por uma língua" (idem ibidem, p.26-27). O propósito da Lingüística é fazer da língua seu objeto, em si mesma e por ela mesma. Não é propor uma filosofia da linguagem, mas considerar a realidade intrínseca da língua tornada possível através da sua estrutura. A língua forma um sistema, um arranjo sistemático das partes. Seus elementos se combinam de modos variados seguindo princípios estruturais: as unidades da língua são articuladas a partir de determinadas relações sendo que cada uma das unidades define-se no seu relacionamento com outras unidades.

Não existe, para a Lingüística de base saussuriana uma diferença entre dados (da língua) e fatos (da língua): as entidades lingüísticas só são determinadas no interior do sistema, umas relativamente às outras. "Os elementos lingüísticos não tem realidade independentemente de sua relação com o todo" (idem ibidem). O valor das unidades é, portanto, relacional. De fato, a lingüística saussuriana substitui a noção positivista do fato lingüístico pela de relação (BENVENISTE, 1991, p.23). Não se procuram as causas de cada elemento, mas cada elemento como parte de um conjunto sincrônico. Nada significa por "vocação natural", mas em função do conjunto e é através do conjunto, das oposições instauradas a cada momento que se pode falar em representação. Os elementos de um sistema lingüístico mantêm entre si relações de dependência e solidariedade, sendo que se um dos membros de uma oposição é atingido, o equilíbrio do sistema é afetado, sendo restabelecido a partir da criação de uma nova relação. Ou seja, a lingüística reintroduz a noção de evolução especificando a diacronia como a relação entre sistemas sucessivos (BENVENISTE, 1991, p.24-25).

Ao estabelecer a noção de valor como eminentemente relativo, a lingüística saussuriana opõe-se à teoria representacional da língua, contradizendo semânticas realistas e pragmático-positivistas que pressupõem idéias preexistentes às palavras. ... "As idéias são contemporâneas das palavras que as exprimem... a língua só funciona como instrumento de comunicação quando funciona ao mesmo 
tempo como instrumento de construção do saber a ser comunicado" (LOPES, 1997, p.104).

Se é possível falar no caráter representacional da língua, portanto, ele só é possível na relação língua/cultura. Uma língua é o seu resultado ou súmula; o meio para ela operar; a condição para ela subsistir' (MATTOSO CÂMARA, 1969, p.22 apud LOPES, 1987, p.21). Cada língua “recorta a realidade" de um modo particular (WHORF apud LOPES, idem ibidem), o que contradiz a idéia de que as línguas espelham a realidade ou pretendam imitá-la, e constituam, assim, tentativas de cópias exatas da realidade. Ao contrário, as línguas expressam modos diversos de apreensão e delimitação de aspectos particulares da realidade que, por sua vez, estão intimamente ligados à experiências também particulares.

A relação homem-mundo é mediada pelo pensamento, e a relação entre os homens é mediatizada por signos, que são "suportes materiais da comunicação entre pessoas" ou "meio pelo qual se exprime a relação entre o homem e o mundo que o cerca" (LOPES, 1987, p.16). Tais mediações conferem às linguagens (e à língua), a condição de sistemas modelizantes. Enquanto sistemas semióticos, as línguas, como as linguagens, são também modalizáveis, porque deixam-se traduzir reciprocamente.

Uma das principais críticas à proposta saussuriana original dirige-se à definição de signo lingüístico como resultante da união de um conceito e uma imagem acústica, e por isso mesmo, mental. A imagem acústica seria o correlato psíquico do som material; o significado e o significante estariam indissoluvelmente unidos no ato da percepção reclamando-se mutuamente. Segundo Hjelmslev, significado e significante são solidários, mantendo entre si uma relação de pressuposição recíproca. Se tal separação poderia pressupor uma aceitação da separação língua/realidade, a variabilidade de formas das línguas distintas faz ressaltar seu caráter não substantivo. A distinção imagem/ conceito dissolve-se quando a língua é vista apenas como um sistema de formas.

Da proposta de Saussure de que a língua é forma e não substância e que toda língua é ao mesmo tempo expressão e conteúdo, Hjelmslev, em direção à Lógica, constrói sua teoria do signo (a glossemática) identificando no sistema dos significantes o plano de expressão, e no sistema de significados, o plano do conteúdo, análoga à distinção significante/significado de Saussure. A língua cria formas a partir de duas substâncias amorfas - o designatum e o som - prendendo numa rede de relações internas essas duas substâncias e imaterializando-as para que elas possam participar de um sistema abstrato. E é nesse sentido que as duas partes do signo, significante e significado, são psíquicas, na terminologia de Saussure. “... as substâncias língüísticas são meros veículos aos quais se imprime uma estrutura relacional abstrata, peculiar a cada língua, operando a transformação da substância em forma". ... "Assim, embora a substância do conteúdo e a substância da expressão sejam praticamente as mesmas para todas as línguas naturais, a forma do conteúdo e a forma da 
expressão diferem de língua para língua” (LOPES, 1987, p.95).

Conseqüentemente, não há idéias preexistentes ao sistema lingüístico (Hjelmslev), mas somente diferenças no interior desse sistema. A língua é um sistema de valores onde cada elemento se define relativamente a outros. Qualquer definição de um termo só pode ser feita de modo relacional.

A atividade de significar, segundo Ducrot e Todorov dar-se ia no ato de comunicação, como na análise de Bühler, visto como um drama de três personagens: o mundo, ou o conteúdo objetivo de que se fala, o locutor e o destinatário. O enunciado lingüístico seria, assim, um signo triplo orientado em três direções: ao conteúdo comunicado - representação (que não implica a idéia de imitação); ao destinatário - a função de apelo; ao locutor - a função expressiva (não como conseqüência mecânica de estados psicológicos). As três funções têm um caráter independente e propriamente lingüístico.

O esquema de Bühler foi completado por Jakobson, determinando o que é inerente ao próprio ato de comunicar, independentemente das intenções ou projetos que o locutor possa ter, recorrendo ao código lingüístico utilizado para comunicar, à mensagem composta e à conexão psicofisiológica estabelecida entre os interlocutores. Jakobson rebatiza as três funções identificadas por Bühler como referencial, conativa e expressiva e acrescenta outras três; a metalingüística, a poética e a fática.

Os filósofos da Escola de Oxford, como Austin, e também o filósofo norte-americano Searle procuram identificar "o que se pode fazer servindo-se da fala", delimitando novas caracterizações dos atos de fala de forma semelhante às propostas de Bühler e Jakobson. A distinção entre as diferentes funções identificadas para a língua, bem como os atos de fala, constituiram uma expressão da preocupação em determinar o que é intrínseco e o que é extrínseco na atividade lingüística, reconhecendo no ato de empregar a língua alguma coisa que lhe é essencial. As análises de Austin, mais do que as de Jakobson, introduzem no jogo lingüístico a questão das relações inter-humanas fundamentais (DUCROT \& TODOROV, 1988, p.305).

Já a perspectiva da sociolingüística postula a existência da linguagem e da sociedade (ou cultura) como duas entidades separadas, procurando através do estudo da primeira a explicação da segunda. A partir do ponto de vista de que é a sociedade que determina a linguagem, alguns estudiosos como Brown e Labov desenvolvem pesquisas procurando estudar as variantes lingüísticas para deduzir as variantes sociológicas. Anteriormente, Humboldt (séc. XIX) havia proposto que a linguagem não seria reflexo das estruturas sociais, psíquicas ou culturais, mas sua causa. Não serviria para designar uma "realidade" preexistente, mas antes organizaria o mundo. Para Weisgerber, Trier, Porzig, do grupo neo-humboldtiano na Alemanha, a linguagem está ligada a uma "visão do mundo" global, sendo que o estudo de cada língua permite o conhecimento do espírito de cada povo (teoria dos “campos semânticos" diretamente organizados em cada língua). Nos EUA, a 
hipótese de 'Sapir-Whorf' procurou mostrar que as categorias do pensamento (tempo, espaço, sujeito, objeto) não eram as mesmas para todas as línguas.

Outra tendência no estudo da relação linguagem-sociedade é a da Antropologia Lingüística que suspendeu a oposição para estudar a linguagem como um fato social, um tipo de comportamento. Malinowski (1923), um de seus principais representantes, distinguiu tipos de enunciado conforme suas funções: enunciados correntes de línguas ocidentais serviriam essencialmente para exprimir o pensamento; enunciados correntes de línguas primitivas, para realizar ações. Somente quando o sentido do enunciado não tem qualquer importância (como para as frases sobre o tempo que têm a função exclusiva de contato), tem-se o modo accional da linguagem.

Halliday, apoiando-se nas teorias de Malinowski também postula a ligação da linguagem ao mundo como funcional. O caráter da língua seria, assim, moldado e determinado pelos usos que dela fazemos. As funções instrumental, regulatória, interacional, informativa e ideacional se integram para exercer a capacidade total da língua. O funcionamento social reflete-se na estrutura da língua, sendo seu aprendizado o aprendizado do "significar". E esse significar se resolve no interior da língua que dá forma à substância lingüística, ou ao continuum da realidade, como na visão de Hjelmslev. O entendimento de como a linguagem se liga ao mundo, portanto, se explicaria nas funções sociais que se desenvolvem a partir da língua.

Já a abordagem da representação pela filosofia da linguagem remete a duas linhas de pensamento distintas: a primeira, voltada ao estudo da linguagem enquanto objeto nas suas relações com outros objetos, preocupando-se em estabelecer as relações entre pensamento e língua e suas interações. Essa corrente é representada pela filosofia idealista francesa do início do séc. XX, que procura mostrar que "a cristalização do sentido em palavras congeladas é uma das causas da ilusão substancialista, da crença em coisas dadas e em estados estáveis". A segunda corrente da filosofia da linguagem interessa-se pelo estudo interno da linguagem. Essa é a corrente dos filósofos ingleses da primeira metade do séc. XX que se intitulam "filósofos da linguagem" e vincula-se às idéias dos lógicos positivistas como Carnap, Moore, Russel e Wittgenstein. O que une esses filósofos é a idéia de que grande parte dos problemas filosóficos, mesmo não sendo falsos, podem não ter sentido, dada a má utilização da língua ou do uso do sentido de palavras como 'bom', 'mau', 'dever', 'valer' retirados da linguagem comum (DUCROT \& TODOROV, 1988, p.96).

As divergências dentro da escola surgem quanto à interpretação do valor da linguagem. Para alguns, a própria linguagem é inconsistente, tornando a pesquisa filosófica falha, como por exemplo, na falsa associação semântica derivada da semelhança gramatical de palavras. Qualidades das palavras teriam sido erroneamente associadas aos objetos ou ações: "Este livro é bom", como se diz "Este livro é vermelho"; ou como no exemplo de Russel "O rei da França é calvo" que 
exprimiria um juízo existencial. A língua, portanto, poderia ter corrompido a filosofia, sendo que a análise da linguagem se impunha como sendo em primeiro lugar uma crítica, postulando-se, a partir daí, a necessidade de uma reconstrução lógica da linguagem. Pode-se identificar aqui o I Wittgenstein (do Tractatus logico-philosophicus) e os filósofos que compartilhavam as idéias neopositivistas de Carnap.

Outra linha dentro da escola analítica é representada pela Escola de Oxford (filósofos da linguagem comum) que não colocam em causa a linguagem, mas o modo como os filósofos a utilizam. As palavras seriam empregadas fora de propósito; as categorias do pensamento seriam aplicadas fora das condições que lhes dariam um sentido objetivo (kantismo lingüístico). "O sentido é o emprego": "descrever o sentido de uma palavra é dar seu modo de emprego, indicar quais os atos de linguagem que ela permite realizar (assim o adjetivo 'bom' teria como valor fundamental tornar possível um ato de linguagem particular, o de recomendar. Dizer 'isto é bom' = dizer 'eu te recomendo isto'). O erro da filosofia tradicional seria justamente haver atribuído às palavras funções para as quais a linguagem ordinária não as destina (empregar, por exemplo, 'isto é bom' como uma descrição do objeto). Não se deve, por conseguinte, afirmar que a língua é ilógica; ela tem uma lógica particular, que se aproxima mais da lógica da ação do que da dos matemáticos, e que os filósofos não discerniram" (DUCROT \& TODOROV, 1988, p.96-97). Esta tendência corresponde ao II Wittgenstein (Investigations philosophiques) que atribui a significação ao “jogo de linguagem”, tendo em Austin o seu principal representante.

Porém, a maioria dos filósofos analíticos distinguem entre sua abordagem e o estudo propriamente lingüístico. Inversamente, os lingüistas não se mostraram muito interessados numa abordagem filosófica das questões lingüísticas. No estudo da referência, os primeiros discutem as condições para a explicação das noções de verdade, crença e existência; os segundos, preocupam-se em elucidar o modo como utilizamos a linguagem para falarmos do que queremos (LYONS, 1977, p.152-153). Já para a 'teoria dos modelos', não há oposição entre as duas, já que a noção de verdade torna-se relativa pelo conceito de 'verdade sob-uma-interpretação'. Na Lingüística, foi Benveniste quem primeiro mostrou interesse pela abordagem da filosofia analítica influenciando trabalhos que procuraram reintegrar, na língua, as relações intersubjetivas que se realizam por ocasião da fala (DUCROT \& TODOROV, 1988, p.94-95).

Do ponto de vista da Documentação, é a noção de representação implícita na lingüística de base saussuriana que nos interessa, porque ela permite constituir teórica e concretamente nosso objeto de trabalho. A noção de estrutura, enquanto arranjo sistemático das partes, não pressupõe uma distinção entre dados e fatos, oferecendo parâmetros para uma abordagem da linguagem documentária a partir da noção de relação. Interessa-nos, por outro lado, verificar como os produtos engendrados a partir da noção de estrutura são passíveis de funcionar como meio para 
o estabelecimento de condições interpretativas. Face a importância da proposta saussuriana para os nossos objetivos, retomaremos a discussão em capítulo à parte.

\subsubsection{A abordagem documentária da representação}

Após verificar como o conceito de representação é abordado pela Filosofia e pela Lingüística, procuraremos identificar como distintos discursos da Documentação enfrentam a questão da representação. As observações relacionadas a seguir evidentemente constituem um recorte que operamos sobre a documentação existente sobre a questão, e é bastante provável que muitas contribuições importantes ao debate não sejam mencionadas.

Analisados no seu conjunto, pode-se afirmar que, enquanto prática social, muitos dos resultados da atividade documentária de representação são caracterizáveis como reprodutores do status qüo, direcionados à manutenção dos monopólios do conhecimento e omissos quanto ao papel de promoção efetiva de acesso ao conhecimento. É o que ocorre a partir do uso dos sistemas de classificação bibliográfica universais.

De fato, a função dos sistemas de classificação bibliográfica elaborados no final do séc. XIX, início do séc. XX, não era exatamente a de promover a transferência da informação, mas a de organizar documentos a partir de uma grade classificatória do conhecimento. A idéia de conhecimento pressuposta pelos sistemas de classificação está ligada a acúmulo e reprodução, o que conseqüentemente, modela o conceito de representação utilizado. Sistemas como o Dewey Decimal Classification - CDD e a Classificação Decimal Universal - CDU, ainda largamente utilizados no Brasil, conjugam o uso da proposta de classificação filosófica do conhecimento preconizada por Bacon (delimitação das disciplinas a partir da tríade "Memória, Imaginação e Razão"), bem como a indução baconiana, aos princípios aristotélicos de divisão dicotômica (ou o uso da árvore de Porfírio, uma releitura do princípio aristotélico que postula a inclusão ou não de qualidades), utilizando, por sua vez, a base decimal como meio de formalizar as subdivisões.

Ao proceder dessa maneira, os sistemas de classificação utilizam a enumeração (decorrente do processo de indução baconiana) simultaneamente ao uso do processo dedutivo para a produção de sub-agrupamentos (árvore de Porfírio), o que explica porque convivem, numa mesma hierarquia, termos que não se organizam hierarquicamente. O modo dedutivo de organização prevalece, pois, sobre o da indução baconiana, sendo, por sua vez, potencializado pela circunscrição da derivação de classes e subclasses à divisão de base decimal. Alia-se, portanto, o princípio dedutivo - que não gera conhecimento - à base decimal, que contribui para a reprodução de um modelo de conhecimento predeterminado. Restringe-se, por outro lado, o uso dos mecanismos de registro 
das associações não-lineares postuladas por Bacon, quando se integra a enumeração à hierarquia. Pode-se afirmar, portanto, que os sistemas de classificação utilizam, a seu modo, um padrão de organização do conhecimento que traz, de forma subjacente, um conceito específico do conhecimento expresso pela cadeia dedutiva limitado a partir de um ponto de enunciação fixo.

Os sistemas classificatórios acima referidos não se restringem a veicular apenas um modelo de conhecimento. Ao contrário, condicionam a representação a um modo determinado de leitura que contribui para a manutenção de padrões preestabelecidos. A grade classificatória de pretensões universalizantes remete à uma divisão estanque do conhecimento e pressupõe uma estabilidade que é assegurada através dos tempos por poucas modificações às propostas originais, uma vez que as alterações presentes nas sucessivas edições não chegam a abandonar o parâmetro inicial a partir do qual foram construídas. Como conseqüência, imprime-se aos documentos representados através do seu uso uma padronização segundo classes pré-definidas, a partir de características privilegiadas pelos sistemas.

$\mathrm{Na} C D D$, as associações entre classes estão, em princípio, interditadas pelo sistema. A síntese entre classes é restrita a alguns aspectos, mais como recurso de economia do que de ampliação de pontos de vista de análise. A possibilidade de combinação de classes (ou de assuntos) preconizada pela $\mathrm{CDU}^{11}$ através dos dois pontos (:) constitui, nesse sentido, um recurso de flexibilização, mas não é suficientemente potente para produzir novos conceitos porque parte da combinação de assuntos, não de conceitos propriamente ditos.

A universalidade dos sistemas classificatórios limita a abordagem dos assuntos às características selecionadas, o que impede sua utilização frente a diferentes propósitos de organização. Embora a CDU seja considerada uma classificação "por aspectos", sua definição a priori condiciona a representação, obrigando a vincular diferentes pontos de vista às classes previstas pelo sistema. Mantida sua estrutura, conserva-se a hipótese original que privilegia a análise dos assuntos a partir de disciplinas tal como à época formuladas.

Pode-se afirmar, além disso, que tais sistemas classificatórios contribuem para a manutenção dos monopólios de conhecimento porque privilegiam o parâmetro preservação (ou acervo) e não o da circulação de informações. De fato, refletem apenas o conhecimento registrado - a partir de uma abordagem datada - não tendo nenhum compromisso explícito com uma prática social efetiva à medida em que não consideram os contextos de uso. Trazem, embrionariamente, objetivos de

11 A CDU é caracterizada pela literatura como uma classificação analítico-facetada. Porém, ao não contar com princípios metodológicos para o registro das subdivisões acaba por fazer conviver, nas hierarquias, conceitos isolados e assuntos pré-coordenados. 
circulação, como quaisquer propostas de organização de documentos (TÁLAMO, 1997), porém pecam quanto às potencialidades de instaurar processos de comunicação. A classificação de textos é realizada através operações de encaixe e de pré-coordenação de assuntos, já que os sistemas efetivamente não dispõem de mecanismos suficientemente potentes para a produção de novas associações que poderiam gerar ou remeter a novos conceitos. Como corolário, não têm compromisso efetivo com a circulação de informações, representando apenas o já dito.

A continuidade do uso dos sistemas de classificação demonstra a ausência de reflexão efetiva sobre as características e objetivos da representação. De fato, as tentativas de adequá-los às necessidades de representação são reconhecidas pelos utilizadores dos sistemas e realizadas, na maior parte das vezes, a partir do senso comum ${ }^{12}$. A restrição a procedimentos do gênero pelas instituições responsáveis pelos sistemas não tem, como contrapartida, instruções para sua consecução. Por outro lado, não existe nos sistemas de classificação qualquer preocupação com o controle de vocabulário (a Lingüística nunca constituiu referência para a construção desses sistemas), além do fato de que as notações classificatórias são praticamente abandonadas no momento de construção dos catálogos para acesso ao conteúdo dos documentos quando são utilizadas listas de cabeçalho de assunto - como a Library of Congress Subjet Headings ou a Sears List - para a elaboração das entradas. Mais grave ainda é o fato de que as entradas destas listas são traduzidas pelas diversas instituições que as utilizam sem outro controle que o catálogo de "rubricas de assunto", instrumento que não permite o controle efetivo do vocabulário, pois não dispõe de uma base estrutural de sustentação.

Experiência que segue os sistemas acima referidos é a da Colon Classification (Ranganathan, 1933) que, sem abandonar a pretensão de cobrir todo o universo de conhecimentos, introduz a noção de agrupamento por categorias e facetas, noção essa que se realiza a partir das características de cada disciplina. O arranjo das características (isolados) dentro de cada classe básica (geralmente disciplinas) relaciona-se à manifestação das categorias Personalidade, Matéria, Energia, Espaço e Tempo. Dentro de cada classe, pois, as categorias transformam-se em facetas de análise, o que permite privilegiar aspectos particulares inerentes a cada uma delas. Essa alteração na concepção de sistemas para a representação de conteúdos de textos mantém o traço básico da lógica aristotélica - as categorias de Ranganathan constituem, de certo modo,

12 Exceção seja feita ao trabalho de Mario Barite, Reformulación de tablas notacionales que, além de sugerir procedimentos para modificação e adaptação dos sistemas, mostra os limites dessa reformulação. A integração de novas formas de contemplar os assuntos é identificada, pelo autor, ao manuseio da caixa de Pandora: reconhecidamente o procedimento mais necessário à atualização dos sistemas, a "integração" mostra-se desaconselhável face ao perigo que representa quanto à sua desestruturação. Estimulada ao longo de décadas pelos seus responsáveis, a intocabilidade dos esquemas faz coexistir uma postura ambivalente entre os classificadores que, embora sacralizem os sistemas, experimentam cotidianamente a necessidade de suprimir ou modificar notações, sem ter meios adequados para fazê-lo. 
categorias aristotélicas ${ }^{13}$ - porém, como elas não se manifestam da mesma maneira nas diversas classes básicas, confere-se maior flexibilidade à análise por aspectos.

A Colon Classification realiza, assim, o início do rompimento com abordagens anteriores, mais lineares e essencialmente dedutivas, ainda que mantendo o caráter enciclopédico através da distribuição dos conceitos pelas disciplinas. Porém, ao distinguir entre plano das idéias e plano verbal (mais um plano notacional que seria apenas instrumental), revela uma concepção de representação que pressupõe, mais do que os sistemas anteriores, a idéia kantiana de dois tipos de representação. O uso da Colon Classification restringiu-se ao seu país de origem, a Índia, ainda que sua influência seja sentida na maior parte dos sistemas classificatórios que lhe procederam. Influência mais evidente verifica-se nas propostas do Classification Research Group - CRG.

A utilização da noção de faceta nos trabalhos do CRG, na década de cinqüenta, é desvinculada da noção de disciplina, diferentemente do que ocorria nos sistemas anteriores. Esse procedimento permitiu flexibilizar a questão da classificação ao introduzir o critério de funcionalidade para a construção dos sistemas, critério esse relacionado às necessidades de arranjo e organização de material bibliográfico de domínios particulares e para fins específicos.

Inicialmente preocupado em elaborar uma classificação universal facetada, o CRG produziu uma série de classificações especializadas voltadas a áreas distintas, principalmente relacionadas ao atendimento de necessidades organizacionais de informação de indústrias ${ }^{14}$. A produção de inúmeras classificações acabou por mostrar, também, as dificuldades - senão a impossibilidade de produzir uma classificação universal facetada. Ficou evidente, através dos trabalhos do CRG, que cada área de especialidade não poderia ser tratada de forma homogênea, ou seja, o tipo e número de categorias de aglutinação variam segundo a especificidade do domínio focalizado. $\mathrm{O}$ Grupo existe até os dias de hoje (as atas de reuniões, anteriormente publicadas pelo Journal of Documentation, são hoje veiculadas através do periódico Knowledge Organization), mas foram os trabalhos publicados entre a década de 50 e 60 os mais significativos enquanto contribuição para o estudo da representação em Documentação.

Merece menção o trabalho de Vickery, um dos integrantes do Grupo, relativo à tentativa de estabelecer categorias que, em princípio, poderiam ser utilizáveis em quaisquer áreas de

13 Personalidade, categoria insuficientemente definida por Ranganathan, aproxima-se da categoria "Substância", de Aristóteles. Energia, de Ação, Operação, Processo etc.

14 Sistemas de classificação elaborados para embalagens da Metal Box Co. (Foskett); para indústrias alimentícias (Foskett); para as Ciências do Solo (Vickery); para segurança ocupacional e higiene do trabalho (Foskett); para a documentação da Unesco em ciências sociais (Barbara Kyle); para tecnologia de explosivos e para o catálogo britânico de música (Coates) etc. Para maiores informações, consultar GROLIER (1962); VICKERY (1960; 1980); FOSKETT (1973). 
especialidade. A experiência com o uso dessas categorias mostra, entretanto, que elas são mais facilmente aplicáveis a domínios que têm um objeto concreto de trabalho. Destaque-se, entretanto, que com o trabalho do CRG a noção de transferência da informação começa a prevalecer sobre a de preservação, pressuposto inerente às classificações tradicionais na sua ânsia de contemplar o universo do conhecimento.

Também a CDD e a CDU não ficaram imunes às influências dessa nova concepção nas suas novas edições, porém a manutenção das disciplinas como origem das subdivisões não permitiu utilizar, verdadeiramente, a concepção facetada de classificação: conjugam-se muitas vezes, no mesmo nível de divisão, princípios de origem distinta, o que, além de desestruturar os sistemas, descaracterizam-nos face à sua proposta inicial.

Entre os sistemas de classificação bibliográfica e os tesauros, inúmeros outros instrumentos foram sucessivamente desenvolvidos para o atendimento de objetivos particulares. É o que se pode verificar através da exposição de Grolier (1962) para quem a proliferação dos sistemas representaria apenas uma fase transitória que estaria preparando uma etapa ulterior quando se poderia substituir essa "anarquia", se não por uma norma universalmente reconhecida, pelo menos por elementos de normalização dos sistemas utilizados. As sucessivas tentativas de propor sistemas revelaram uma tendência em decompor os assuntos complexos em "fatores" simples, o abandono de classificações fortemente hierarquizadas e a tomada de consciência da necessidade de exprimir não apenas os termos elementares que servem à análise dos documentos, mas ainda as relações entre eles (GROLIER, 1962, p.4-10).

O relatório de Grolier, elaborado em atendimento à solicitação da UNESCO, órgão que centralizou as preocupações de inúmeras reuniões que se desenvolveram entre a década de 50 e 60 , teve como objetivo identificar "categorias suficientemente gerais para serem introduzidas nas classificações ou codificações de numerosos domínios diferentes do conhecimento", já que as chances de se construir uma classificação internacional normalizada mostraram-se muito adversas (GROLIER, 1962, p.12).

Muito embora a intenção do relatório tenha sido essa, do nosso ponto de vista é interessante observar que, de forma intuitiva ou não, vários sistemas ou 'codificações' buscaram, invariavelmente, modos de agregação para suas informações não necessariamente pautadas nos sistemas filosóficos, porém em necessidades funcionais. Se tais categorias poderiam ser generalizáveis para quaisquer propostas organizacionais é um outro problema.

Categorias gerais foram buscadas nos sistemas de classificação bibliográfica enciclopédicos e especializados, porém não se limitaram a elas. O movimento estimulado pelos trabalhos sobre 
tradução automática que, embora guardem suas especificidades relativamente à recuperação automática de informação deles se aproximam, mostrou a importância da Lingüística como via de pesquisa para a representação de informações.

No quadro apresentado por Grolier, os estudos sobre as categorias e relações nas línguas naturais e nas línguas especiais ("langues auxiliaires internationales") são repertoriados a partir da constatação que:

a) a tradução automática não pode dispensar o estudo das estruturas lingüísticas dos documentos correspondentes;

b) a documentação, na sua tarefa de delinear uma linguagem documentária racional e normalizada em escala internacional, não pode ficar limitada ao modelo das classificações e codificações elaboradas no passado.

O problema identificado pelo autor, à época, era a ausência de estudos sistemáticos gerais de caráter teórico, até porque "a lingüística contemporânea seria, ela mesma, uma espécie de torre de Babel, onde se afrontam teorias diversas que não empregam sequer uma terminologia unificada" (GROLIER, 1962, p.150).

Na verdade, o panorama apresentado é extremamente genérico (como o reconhece o próprio autor). Não fica claro o que, de fato, a Documentação pretendia buscar no "estudo das línguas naturais". Na busca que realiza pelos estudos das "línguas naturais" - que o autor agrupa por países -, são enumerados vários conceitos considerados como importantes investimentos de pesquisa, tais como os de língua como sistema estruturante (Humboldt), teoria dos campos semânticos, lingüística sincrônica (Saussure), 'conceitos racionais' (Brunot), esquema sub-lingüístico (Guillaume), a glossemática (Hjelmslev), teoria das oposições (Trubeckoj, Jakobson), conceitos da lógica (Bröndal), relações entre língua e cultura (Whorf) etc. O autor também aponta os trabalhos de Bloomfield, Sapir, Harris, Chomsky, entre outros, além de se referir a vários autores da Polônia, Hungria, Tchecoslováquia, Rumânia, URSS, Ioguslávia e China, muitos dos quais ligados à tradução mecânica.

Enquanto uma proposta de um "magro esqueleto de orientações bibliográficas", como ele mesmo o diz, Grolier destaca as preocupações com a definição e denominação de classes de palavras, o estudo de categorias verbais, os sistemas de casos, as noções de gradação, totalidade, ponto de finalização, de indicação. Aponta, também, a importância dos trabalhos de semântica, sistemas conceptuais, relações entre linguagem e lógica, linguagem e pensamento, linguagem e cultura e tipologia das línguas sem, entretanto, aprofundar quaisquer delas e restringindo-se a constatar que a linguagem influenciaria a transmissão de informações (GROLIER, 1962, p.160), porém principalmente enquanto uma preocupação ainda ligada à construção de uma 'linguagem científica unificada'. 
De fato, a partir da década de 60, muitos autores da área de Documentação passam a procurar referência na Lingüística, seja porque identificam semelhanças entre os problemas de interface de representação de itens documentários/perguntas dos usuários e aqueles encontrados nas tentativas de tradução automática (MONTGMOMERY, 1972 apud KOBASHI, 1995, p.33), seja porque acreditam que os processos documentários envolvem questões sintáticas e semânticas (SPARCK JONES \& KAY, 1973 apud KOBASHI, 1995, p.33).

Coyaud, por exemplo, fala da função comunicacional das linguagens documentárias ${ }^{15}$, porém utiliza uma noção ainda primária de comunicação, entendendo uma linguagem documentária apenas como "ferramenta mediata entre os clientes e os autores dos documentos" (COYAUD, 1966, p.5). Nessa condição, as linguagens documentárias refletiriam a estrutura da primeira língua sobre as quais são edificadas (idem ibidem, p.127). O enfoque privilegiado por Coyaud recai sobre o ponto de vista sintático, remetendo à Lógica os problemas de natureza semântica. $\mathrm{O}$ "grau de motivação do vocabulário", segundo sua terminologia, é uma função derivada do grau de redução lógica operada para a criação das linguagens ou do número de relações analíticas definidas (COYAUD, 1966, p.82).

Fica evidente, no estudo de Coyaud, a preocupação em determinar um "nível ótimo de generalidade dos conceitos a serem expressos pelo léxico documentário", ou seja, o autor busca uma objetividade documentária e manifesta a ânsia de encontrar a "característica universal leibziniana" (COYAUD, 1966, p.81-84).

Já em Gardin, uma das principais referências para a pesquisa sobre a representação documentária, a preocupação é a de identificar parâmetros formais para o desenvolvimento da Análise Documentária. Diferentemente das várias análises de texto, o processo de Análise Documentária - que levaria à construção das representações documentárias, conforme a terminologia que utilizamos - se caracterizaria por uma série de procedimentos empíricos. Gardin é um dos primeiros pesquisadores a utilizar parâmetros lingüísticos para a organização de um modelo de linguagem documentária: no eixo paradigmático se realiza a estruturação lógico-semântica da linguagem, e no eixo sintagmático, sua articulação através de regras sintáticas.

O autor não vê, porém, na Lingüística da época (principalmente a lingüística chomskyana, da década de 60) contribuições práticas significativas (GARDIN, 1973b, p.73-74), identificando na semântica (Katz e Fodor, Mel'Chuk etc.) e na Lógica (Lakoff, por exemplo), as maiores fontes de contribuições. Exemplo disso é a menção à possibilidade de trabalhar a questão da ambigüidade

15 As Linguagens Documentárias constituem "um sistema de signos que permite ao cliente de um centro de documentação (e em particular, de uma biblioteca), se comunicar com um documentalista" (COYAUD, 1966, p.5). 
através dos estudos semânticos (mais identificados com a Lógica do que com à Lingüística, à época) e o uso de categorias lógicas que, combinadas ao uso de estruturas funcionais remeteriam à noção de "pressuposição", a partir da qual seria possível selecionar interpretações de interesse. As pressuposições contemplariam a incorporação dos fatores contextuais para a análise da significação, o que, para Gardin, revelaria a natureza metalingüística da atividade documentária com a significação (GARDIN, 1973a, p.156-157; 1973b, p.84-85).

Também para Gardin, existiriam conjuntos de funções universais comuns a diversos universos de discurso - tal como aqueles identificados pelas classificações documentárias facetadas - Agente, Paciente, Instrumento, Objetivo etc (GARDIN, 1973a, p.156-158) - apesar de identificar limitações teóricas e práticas das propostas de metalinguagens universais (GARDIN, 1989).

A importância conferida à Lógica pode ser identificada, por exemplo, através de citações de Lakoff: "as deduções da lógica natural são uma primeira aproximação para a representação formal do processo de pensamento" ... "a gramaticalidade deve ser definida relativamente às suposições sobre contextos situacionais e processos de pensamento" e, conseqüentemente, "o estudo da lingüística e o estudo da lógica natural devem estar juntos" (LAKOFF, apud GARDIN, 1973,p.158).

Paralelamente ao uso de parâmetros lingüísticos, a lógica também está presente na construção do SYNTOL - Syntagmatic Organization Language, coordenada pelo autor. Modelo aplicável teoricamente a quaisquer universos de textos, o SYNTOL utiliza uma unidade básica de relações expressa a partir do sintagma mínimo ‘ $\mathrm{Ri}(\mathrm{x} . \mathrm{y})$, onde x e y são termos do léxico e R é uma relação binária cujo significado é especificado por i. Através desse sintagma mínimo é possível representar relações de natureza paradigmática mas, principalmente, sintagmática: relações reais, que pressupõem a interdependência entre dois significados (dinâmicas, para representar relações consecutivas ou de causalidade e estáticas, para representar superposição de conceitos, seja de natureza associativa e predicativa) e relações formais (coordenativas, comparativas e aproximativas). A esse conjunto de relações são associados operadores sintáticos para evitar ambigüidade interpretativa e o desenvolvimento sistemático de relações implicadas pelo encadeamento de certos sintagmas adjacentes. Experiência pioneira e sem similar na área documentária até os nossos dias, a proposta de Gardin poderia se constituir em fonte de pesquisa para dar conta dos problemas de sintagmatização que têm sido, até hoje, resolvidos apenas a partir do uso de lógica booleana.

A utilização da lógica está presente, também, em seus trabalhos relativos à recuperação dos processos de raciocínio que sustentariam as construções nas Ciências Humanas e, particularmente, na Arqueologia. Supondo como referência básica o discurso das áreas exatas Gardin propõe, através da análise "logicista", a esquematização dos processos de raciocínio (dedutivo ou indutivo) sob a forma de proposições lógicas, que vão da descrição, à interpretação dos dados. As 
representações obtidas a partir dessa análise são expressas por um sistema simbólico artificial, constituído de dados, proposições e raciocínios. Os textos científicos seriam “construções”, e o trabalho de resgate de raciocínios procuraria estabelecer "o ponto entre as observações empíricas, de um lado ... e as hipóteses teóricas de outro ...” (GARDIN, 1987, p.185), realizando a ligação entre as observações empíricas e as hipóteses teóricas (empírico-indutivo ou hipotético-dedutivo). $\mathrm{O}$ “cálculo" realizado para a restituição dos raciocínios assume a forma de uma seqüência de operações de reescrita, indo de $\{P o\}$ - dados de base ou proposições descritivas - para $\{P n\}-$ proposições terminais no vértice da construção - intermediadas por $\{P i\}$ - proposições intermediárias ligadas por operações de inferência empírico-dedutivas ou hipotético-dedutivas, conforme o ponto de partida da análise.

Jean-Claude Gardin é um dos primeiros autores a reconhecer que a atividade de representação documentária se desenvolve no universo da linguagem. Responsável pela introdução do termo “Análise Documentária" na literatura da Documentação, Gardin identifica a atividade de representação documentária como um gênero de representação probabilística resultante de escolhas empíricas realizada para a expressão do conteúdo de textos científicos: significados de textos são retirados e substituídos por outros que não são, necessariamente, encontrados no texto - o que caracterizaria operações de construção de metalinguagens - com o objetivo de permitir buscas retrospectivas de informação (GARDIN, 1970, p.630; 1973a, p.144; 1973b, p.67). Suas propostas revelam, entretanto, os problemas de um modelo neopositivista.

Tendo como referência modelos lingüísticos, a questão da representação também é enfrentada por pesquisadores no Brasil, como em SMIT (1996, 1987); CINTRA (1983, 1987); CINTRA et al. (1993, 1994); CUNHA (1987, 1990); AMARO (1991); LARA (1993); KOBASHI(1989, 1994), BARANOW (1979, 1983); TÁLAMO (1987, 1994); TÁLAMO et al. (1992, 1992a) etc., para citar apenas alguns trabalhos. Do mesmo modo, García Gutiérrez, pesquisador espanhol, aborda a questão da representação documentária sugerindo a interface Lingüística/Documentação através da proposta de uma “Lingüística Documental” (GARCÍA GUTIÉRREZ, 1990).

Caminho diferente seguiu Blair, cuja influência remonta aos trabalhos do $2^{\circ}$ Wittgenstein, razão pela qual julgamos conveniente comentar com mais detalhe. A construção das representações de conteúdo (subject descriptions) é, para o autor, um ato claramente lingüístico que se caracteriza, simplesmente, pelo uso de palavras de uma maneira particular em certos tipos de situação.

A concepção das descrições de conteúdo remete às Formas de Vida (Forms of Life) e aos Jogos de Linguagem (Language Games) nas quais tais descrições são usadas, que permitem uma espécie de "visão mais ampla" ou "perspicuidade" sobre os modos de uso das descrições de assunto. Não se trata de pretender uma definição das descrições de assunto, mas de alcançar uma compreensão 
através do olhar para exemplos específicos de como as palavras são usadas, bem como em que atividades ou contextos sociais elas são usadas.

Os tipos de "atividades" nas quais deveríamos usar uma descrição de assunto nos são "familiares" e servem de contexto para a recuperação de um assunto. A natureza da atividade influencia a pesquisa (em função do tipo de linguagem ou jargão das atividades, sua maior ou menor estruturação), como também o nível de exaustividade necessário a uma recuperação satisfatória. Os Jogos de Linguagem proveriam um tipo de estrutura formal para o uso de descrições de assunto.

Assim como não existe, em Wittgenstein, uma definição formal dos Jogos de Linguagem, não há também uma relativa às descrições de assunto: "Você fala sobre todos os tipos de jogos de linguagem, mas nunca disse o que em essência é um jogo de linguagem, e nem o que é linguagem: .... Ao invés de produzir alguma coisa comum para tudo que chamamos linguagem, tenho dito que este fenômeno não tem nada em comum que nos faça usar a mesma palavra para tudo, mas afirmo que elas estão relacionadas umas às outras de várias maneiras diferentes. E é por conta desse relacionamento que nós as chamamos todas "linguagem" ... "Considere por exemplo os procedimentos que chamamos de jogos. ... O que é comum entre eles? Não diga: deve existir algo em comum, ou eles não poderiam ser chamados jogos - mas olhe e veja, entretanto, que há alguma coisa em comum a todos. Se você olhar para eles você não verá alguma coisa que é comum a todos, mas similaridades, relacionamentos, e toda uma série deles. Repetindo: não pense, mas olhe!" (WITTGENSTEIN, apud BLAIR, p.159).

Blair sugere adotar a perspectiva de Wittgenstein para quem existem entre as palavras relações multivariadas: correspondências, traços característicos aparecem e desaparecem; similaridades aparecem e desaparecem. Segundo essa proposta, a partir do exame dessas relações poderíamos ver a complicada rede de similaridades que atravessa os textos. Essas "são 'semelhanças de família' (family resemblances); as várias semelhanças entre membros de uma família - constituição, traços, cor dos olhos, jeito de andar, temperamento etc. - sobrepõem-se e se atravessam ao mesmo tempo. Os “jogos", assim, formam uma família' (idem ibidem, p.160).

A compulsão para procurar por definições e explicações compreensivas é uma conseqüência de nossa “obsessão pela generalidade", e é devida primariamente a várias tendências:

a) "tendência a olhar para alguma coisa em comum a todas as entidades que comumente se subsumam sob um termo geral. Isso é comparável à idéia de que as propriedades são ingredientes das coisas que têm as propriedades ...

b) tendência original de pensar que o homem que aprendeu a entender um termo geral, como por exemplo "folha", tem, conseqüentemente, que possuir uma espécie de imagem de folha oposta às figuras particulares de folhas... Isso se ligaria à idéia de que o significado de uma palavra é 
uma imagem, ou uma coisa correlacionada à palavra. (Esta aproximação significa que olhamos para palavras como se elas fossem nomes próprios, e então confundimos o portador de um nome com o seu significado );

c) ... a idéia que temos do que acontece quando apanhamos a idéia geral de folha, planta, etc, etc., é conectada com a confusão entre um estado mental, significando o estado de um mecanismo mental hipotético e um estado mental significando o estado de consciência (dor de dente, etc.).

d) Nossa obsessão por generalidade tem outra fonte principal: nossa preocupação com o método da ciência. Eu digo (mean) o método de reduzir a explicação de um fenômeno natural ao menor possível número de leis primitivas naturais; e em matemática, de unificar o tratamento de diferentes tópicos usando a generalização ... não pode nunca ser nosso trabalho reduzir qualquer coisa a qualquer coisa, ou explicar qualquer coisa. A Filosofia, realmente, é 'puramente descritiva"" (idem ibidem, p.160-161).

Nesse contexto, as definições funcionariam apenas quando já possuirmos um entendimento básico de como as palavras ou frases são/podem ser usadas. "Os dicionários são úteis ao enumerar diversos usos, mas as definições ‘completas' podem ser inadequadas se não estamos pessoalmente familiarizados com as atividades e formas de uso nas quais elas ocorrem (definições de dicionários especializados para pessoas que não o são)" (idem ibidem).

Transpondo a situação para analisar a questão das representações de assunto, Blair sugere que na procura de traços gerais do processo de busca por assunto são mais significantes:

a) o jargão ou gíria de uma atividade na qual o pesquisador está participando que determinaria as palavras ou frases a serem utilizadas para procurar por uma informação;

b) o grau de exaustividade desejado;

c) o tamanho da coleção de informação/documentos da qual o material sobre o assunto será selecionado.

Os sistemas tradicionais de recuperação de informação não são, para o autor, sensíveis ao jargão, supondo-se que um vocabulário controlado ${ }^{16}$ constituiria uma base suficiente para julgar como representar o conteúdo do documento, porém deixam de lado idiossincrasias utilizadas pelos usuários. As diferentes “atividades" demandam diferentes maneiras de representação. (Sob nosso ponto de vista, a distintas atividades correspondem distintas terminologias). Na classificação de documentos nem sempre encontramos características distintivas tal qual nas classificações científicas, já que a tipificação de um documento pode ser realizada de diversas maneiras, privilegiando pontos de vista diferentes a cada momento. O critério para se atribuir uma descrição de assunto particular

16 A concepção de vocabulário controlado utilizada por Blair não coincide exatamente com a que vimos utilizando neste trabalho. 
é a utilidade que a representação escolhida teria para atender as "preferências lingüísticas" do pesquisador. (Na ótica deste trabalho, acreditamos que não se trata exatamente de preferências lingüísticas, mas de conhecimento da terminologia do domínio - e um domínio pode ser relativo a uma atividade, não necessariamente científico).

Ao realizar a oposição entre pesquisa em coleções pequenas e grandes coleções, Blair ressalta que, em grandes sistemas, o espaço lingüístico das descrições de assunto é muito maior, já que o usuário não conta com a ajuda dos advisors, profissionais para os quais o assunto da coleção é "familiar".

Diferentemente do que propomos, a atividade de indexação seria, para o autor, um processo lingüístico sujeito às mesmas tendências e regularidades dos processos em linguagem natural. $\mathrm{O}$ significado lingüístico e o uso seriam governados por "semiose ilimitada": não há limite prático ou teórico para o número de diferentes palavras e combinações que poderiam ser usadas para expressar a mesma idéia ou significado. Porém, enquanto cresce o entendimento da realidade da semiose ilimitada na linguagem, "não é claro que ele governa o 'dialeto' da linguagem natural conhecida como descrição de assunto" (BLAIR, 1990, p.169). As atividades (Formas de Vida) nas quais estamos engajados - e os Jogos de Linguagem relevantes a essas atividades - limitam tacitamente a linguagem que usamos a um pequeno subconjunto do que poderia ser possível usar nessas circunstâncias (idem ibidem, p.239).

Blair vê duas perspectivas para enfrentar o problema da semiose ilimitada:

a) há um número ilimitado de documentos para os quais uma simples descrição de assunto poderia ser usada;

b) há um número ilimitado de descrições de assunto que poderiam ser utilizadas para representar qualquer documento.

Vê-se, portanto, que sua perspectiva para abordar a questão da semiose ilimitada concentra-se, diferentemente da leitura que realizamos, na questão da recuperação propriamente dita: o autor não incorpora à discussão o problema da recepção.

A abordagem de Blair, entretanto, tem o mérito de reconhecer que a indexação tradicional confunde a gramática ou forma da classificação de um documento com a gramática ou forma da classificação científica, especialmente a biológica, como ele ressalta. Supõe-se, nesse processo, que a descrição de assunto tenha um significado claro e definível e que um documento tem um assunto simples que pode ser representado por um pequeno número de descrições. A primeira suposição parte de uma concepção errônea de que expressões têm conteúdos: no seu entendimento, tais expressões 
têm usos, e são para esses usos que precisamos olhar, ao invés de definições extensionais ou intensionais. Segundo nosso ponto de vista, a proposta da lingüística semiótica da relação expressão/ conteúdo considera o contexto. Sendo assim, as definições expressariam os entendimentos contextuais correspondentes aos usos. Através da definição tornaríamos claro o uso feito da palavra, ou o aspecto a salientar numa determinada situação. O problema, então, talvez não esteja em usar ou não uma definição, porém usá-la ao modo semiótico para incorporar os aspectos pragmáticos.

Concordamos com o autor quando ele afirma que nem sempre os usos são completamente passíveis de serem circunscritos por uma definição, muito embora ele esteja se referindo, muito provavelmente, ao conceito clássico de definição (o aristotélico). Algumas vezes o uso só pode ser mostrado, como é o caso dos termos de áreas em formação ou transformação, cuja estabilidade não está firmada, para os quais a Terminologia descritiva aponta a extração do contexto como fonte para a coleta do uso dos termos.

A concepção de representação de Blair, diferentemente da nossa, não está baseada em hipóteses de oganização. Não pressupõe, também, que a descrição é uma construção, razão pela qual sugere utilizar um termo de pesquisa (uma descrição de assunto) tal como na linguagem ordinária. Essa sugestão tem como base a crença de que é a partir do uso que adquirimos a linguagem, e que essa aquisição prescinde da existência de definições e explicações isoladas. (De fato, isso pode ser verdade em relação à aquisição da linguagem natural, mas não o é relativamente às linguagens construídas).

Nos sistemas de recuperação de informação a aprendizagem seria realizada através de exemplos 'perspicuosos' e a partir de ambientes que permitissem ao usuário aprender como usar mais apropriadamente as descrições. Informações sobre atividades típicas que produzem ou usam determinados documentos seriam úteis para representá-los e recuperá-los. A categorização dos assuntos não poderia estar restrita às tradicionais categorias "essenciais", mas àquelas que se mostrem úteis a determinados objetivos. Ao lado da contextualização das descrições, a existência de mecanismos para incentivar a comunicação entre pesquisadores e indexadores e a possibilidade de umfeedback automático contribuiriam para uma boa recuperação (idem ibidem, p.178).

Blair reconhece a natureza lingüística do processo e vê que a recuperação da informação envolve um problema comunicacional, porém concebe a linguagem de recuperação de informação como um dialeto de linguagem natural, o que distingue sua proposta daquela que vimos nos propondo a construir. Não deixa de ser, entretanto, uma contribuição polêmica.

Em síntese, os exemplos que levantamos sobre os modos de enfrentamento da representação em Documentação mostra como diferentes paradigmas científicos permeiam, também, os discursos da área. Alguns deles não mostram claramente seu comprometimento com os diferentes pressupostos 
que pautaram os distintos discursos das ciências, porém pode-se inferir das suas propostas quais os pontos de partida adotados; outros, são mais comprometidos com o modelo positivista quando procuram no modelo das ciências exatas a referência para um tratamento formal da questão documentária. Ao compartilhar das idéias do 2o. Wittgenstein, o discurso de Blair difere da maior parte da literatura documentária, porque questiona parâmetros fundantes de representação, na maior parte das vezes assentados na crença nas essências e ávidos pela descoberta de categorias gerais de análise. Essa proposta, porém, ignora as contribuições geradas no interior de outros paradigmas e corre o risco de utilizar apenas o senso comum como parâmetro. As Atividades (Formas de Vida) não são mais do que as terminologias de domínio do saber ou de atividades vistas sob o ângulo da Socioterminologia, cuja ênfase, veremos à frente, está centrada no uso. A grande diferença está em propor os Jogos de Linguagem na ausência de um reconhecimento mais explícito das características comunicacionais da representação da informação. 


\section{A OPERACIONALIZAÇÃO DOS CONCEITOS LINGÜÍSTICO- SEMIÓTICOS NA CONSTRUÇÃO DA REPRESENTAÇÃO DOCUMENTÁRIA}

O principal objetivo das linguagens documentárias, instrumentos de representação documentária, é o de promover a circulação de informações, o que remete à necessidade de que as representações possam ser reconhecidas a partir de hipóteses de organização de informações. É um princípio de ordem, portanto, enquanto condição de sistematização que deve ser a base para o reconhecimento de indicadores que levem à construção da informação. Trata-se de prover arranjos que permitam a participação do usuário para a atualização das mensagens, seja através do reconhecimento de descrições, seja através da inferência de suas relações.

Se a Filosofia contemporânea nos fornece elementos para compreendermos que o terreno sobre os quais nos movemos permite falar mais em "descrições" do que em representações (supondo como o vocabulário da ciência moderna marcou o termo 'representação' vinculando-o ao conceito de "substância"), e se é ela também que nos faz entender que as descrições são caracterizáveis, antes, pelas propriedades que elegemos para observar a realidade, e não pela presença intrínseca dessas propriedades nos fatos e fenômenos da realidade, é a Lingüística de base saussuriana que nos fornece ferramentas para instrumentalizar tais descrições. Essa apropriação também se reportará às contribuições teóricas e práticas da Documentação.

\subsection{Estrutura lingüística e estrutura das linguagens documentárias}

A noção fundamental para a construção de uma linguagem documentária é a de estrutura lingüística. A estrutura lingüística é devida a Saussure e "está intimamente ligada à de relação no interior de um sistema" (BENVENISTE, 1991, p.100). Entendida como um modelo, uma construção mental que serve de hipótese de trabalho, ela permite descrever a língua como uma "entidade autônoma de dependências internas” (HJELMSLEV, 1971, p.28 apud LOPES, 1987, p.39).

A proposta saussuriana inaugura "o pensamento da descontinuidade na história da ciência moderna" (LOPES, 1997, p. 15). Não se consideram os termos-objetos objetos - objetos do ato de conhecer - eles mesmos, mas antes as relações que os unem dentro do sistema.

A alteração introduzida pela lingüística saussuriana alinha-se a toda passagem do pensamento contínuo para o descontínuo ocorrida no terreno das artes - a substituição do epistema realista que se caracterizava pela espacialidade imaginária contínua, pelo epistema cubista -, e das ciências - a teoria dos quanta, a teoria da relatividade e a descoberta dos átomos, partículas, íons, gens etc. - no 
início deste século (idem ibidem, p. 19,20). O princípio da descontinuidade evidencia a possibilidade de fracionar o que parecia indivisível possibilitando a análise, além de permitir reconhecer a existência de espaços vazios entre uma unidade e outra (TEIXEIRA COELHO, 1995, p.31).

A noção de substância, tal como a afirmada pela filosofia cartesiana, não interessa à análise estrutural. Na realidade, ela é uma contextura de atributos (BACHELARD, 1934 apud PEÑALVER SIMÓ, 1972, p.14), uma estrutura de relações, constituindo um sistema. Afirmar que um campo de fenômenos constitui um sistema é "afirmar sua sistematicidade, sua imanência, sua natureza relacional" (PEÑALVER SIMÓ, 1972, p.16). Um sistema pressupõe uma ordem, cujo princípio explicativo remete à configuração que o define em sua singularidade e variabilidade. A noção de estrutura, por sua vez, exige objetivação porque é uma noção abstrata, já que o sujeito lingüístico não tem consciência da estrutura elementar da língua: a rede de relações entre os elementos não se apresenta simplesmente (idem ibidem, p.12). De fato, os termos são interdependentes, e só o relacional é explicativo. A atividade de abstração promovida pela análise à base das relações permite identificar as organizações, as correlações, as correspondências. A noção de estrutura, por sua vez, pressupõe um princípio epistemológico anterior: “o princípio da sistematicidade do real” (idem ibidem,15-16).

A idéia de estrutura é aprofundada por Greimas, que a define como sendo "a presença simultânea, em nossa mente, de dois termos-objetos ligados por uma relação" (LOPES, 1987, p.40): a relação é, ao mesmo tempo, conjuntiva - os termos-objetos são parcialmente idênticos -, e disjuntiva - os termos-objetos são parcialmente diferentes). A língua é feita de oposições, e enfocar o problema da significação exige "afirmar a existência de descontinuidades, no plano da percepção, e dos espaços diferenciais ... criadores de significação, sem se preocupar com a natureza das diferenças percebidas" (GREIMAS, 1976, p.28). "O mundo toma forma diante de nós porque percebemos diferenças”. Perceber diferenças significa:

a) captar ao menos dois termos-objetos como simultaneamente presentes;

b) captar a relação entre os termos ligando-os de algum modo;

Disso decorre uma primeira definição de estrutura, dada pela presença de dois termos e da relação entre eles, que, por sua vez, tem as seguintes conseqüências:

a) Só um termo-objeto não comporta significação;

b) A significação pressupõe a existência da relação, ou seja, o aparecimento da relação entre os termos é condição para sua significação.

Tais conseqüências permitem aprofundar a noção de estrutura, conforme segue:

a) Conjunção: para que dois termos possam ser captados juntos é preciso que tenham algo em comum (semelhança, identidade); 
b) Disjunção: para que dois termos possam ser distinguidos é preciso que sejam diferentes, qualquer que seja a forma (problema da diferença e da não-identidade) (GREIMAS, 1976, p. 29).

Na base da análise da estrutura lingüística está, pois, a noção de valor, não levando em conta a identidade da substância fônica ou semântica. Desse modo, a estrutura não se compõe de 'coisas' (meros funtivos, para Hjelmslev), mas de 'relações', podendo-se afirmar que os valores são constituídos:

"1o. por uma coisa dissemelhante susceptível de ser trocada pela coisa cujo valor resta determinar: 2o. por coisas similares que se podem comparar com a coisa cujo valor está em causa" (SAUSSURE, apud LOPES, 1987, p.40).

A noção de estrutura é básica para a compreensão e organização das linguagens documentárias. A comparação entre uma lista de assuntos - como as listas de cabeçalho de assunto alfabéticas ainda utilizadas pelas Bibliotecas - e listas estruturadas, como os tesauros, permite evidenciar a utilidade dessa noção. Uma lista alfabética de assuntos, muito embora possa se basear na garantia literária, tem como ponto de partida um critério altamente arbitrário que é o alfabeto. Assim elaboradas, as listas de cabeçalhos de assuntos assemelham-se aos dicionários de língua, cuja "continuidade" supostamente assegurada pelo "alfabeto" revela apenas o registro do léxico ou repertório da língua. Nessas listas as palavras não são portadoras de significado porque este é remetido às várias possibilidades de sentido registradas pelo léxico: ao significar potencialmente tudo, acabam por não significar nada.

A absorção da idéia de estrutura no âmbito da Documentação ainda não é feita de forma consistente. “... ainda hoje associa-se significado da linguagem documentária com algo que está fora dela, por exemplo, a área de conhecimento da qual participa, a matéria prima ou o conhecimento a ser tratado. Imagina-se que ao agrupar uma série de palavras típicas de uma área de conhecimento garante-se forte credibilidade desse conjunto de palavras, tornando-o representativo". Porém “ ... é somente a rede de relações das unidades de uma linguagem que pode contribuir para o exercício de qualquer representação" (TÁLAMO, 1977, p.4).

A utilização da noção de estrutura permite compreender a necessidade de:

a) Definir o universo-objeto de trabalho (do mesmo modo que a língua, é impossível estruturar todo o universo de termos);

b) identificar qual é o vértice para a análise supondo o fragmento sobre o qual se irá operar (ou, dito de outro modo, qual é a hipótese a partir da qual serão organizados os eventos, ou qual é a oposição fundamental a ser estabelecida);

c) estabelecer a rede de relações entre os termos a partir da noção de oposição. 
A idéia da descontinuidade instaurada pelo estruturalismo saussuriano - e seu epistema - implica, para a Documentação, a necessidade de questionar a constituição de sistemas enciclopédicos, tal como os propostos para o arranjo das coleções das bibliotecas no final do séc. XIX - início do século XX. Primeiro, porqueé impossível pretender estruturar todo o universo do conhecimento; segundo, porque, ao estabelecer a rede de relações com base em oposições efetua-se uma escolha, a partir da qual todas as outras (passíveis de serem selecionadas) estarão descartadas. E é evidente que o conhecimento não se organiza apenas segundo um ponto de partida. De fato, os sistemas de classificação enciclopédicos compartilham o princípio de que o conhecimento poderia ser representado de forma sintética.

A noção de estrutura é um construto teórico e sua operacionalização nas linguagens documentárias permite evidenciar que a sistematização sempre é relativa à fragmentos organizados a partir de um ponto de vista selecionado, entre outros.

\subsection{As propriedades estruturais da língua como referência para a construção de linguagens documentárias}

O estruturalismo representou a introdução de um conjunto de categorias teóricas com valor metodológico que poderiam ser expressas como propriedades dos conjuntos significantes a serem descritos, quais sejam: relatividade, funcionalidade, unidade, totalidade, transformabilidade e autoregulatividade (LOPES. 1997, p.35). Tais categorias podem ser assimiladas pela Documentação enquanto parâmetros para a organização estrutural das linguagens documentárias.

"Por relatividade podemos entender que, nada mais, no interior de um conjunto significante... poderia continuar a ser identificado, classificado, estudado ou definido por sua natureza (como nos epistemas historicistas e positivistas, anteriores ao estruturalismo), mas somente por sua função" (idem ibidem).

Ao enfatizar o princípio relacional do sistema Saussure revela que "o mecanismo lingüístico gira inteiramente sobre identidades e diferenças" (SAUSSURE, 1972, p.151 apud LOPES, 1997, p.35). Como conseqüência, nenhum elemento existe sozinho numa mensagem, nem pode ser definido por sua natureza de forma isolada, mas sempre em referência a outro elemento da mesma formação.

Isso evidencia que a estruturação de um vocabulário para fins documentários deve pressupor o relacionamento entre seus elementos como meio de torná-los definíveis a partir de uma hipótese de organização. Não se trata de analisar as características dos objetos, mas de descrevê-los segundo aspectos julgados pertinentes para determinados propósitos e em função da hipótese inicial considerada. A relatividade se configura, nas linguagens documentárias, sobre aquilo que se determina, local e temporariamente, como informação. “. . . as unidades de uma linguagem não encontram seu fundamento 
na realidade extra-lingüística, o qual só pode ser explicado a partir da organização interna ..." (TÁLAMO, 1997, p.4). A linguagem não se define pela realidade a que se refere, mas "se refere à realidade segundo a forma constitutiva que apresenta" (idem ibidem, p.9). Portanto, a representação da informação, através das linguagens documentárias deve "ser entendida como uma conseqüência das relações que foram instituídas entre as unidades lingüísticas no interior dessa mesma linguageme não como decorrência da mera presença dessas unidades" (idem ibidem, p.6).

"Quanto à funcionalidade, se compreendermos por função o princípio da utilidade local de um elemento dentro de um conjunto, o seu uso local ... diremos que a função de cada elemento se define por uma referência dele a qualquer outro elemento pertencente ao seu mesmo conjunto, visto que dois elementos inscritos no mesmo universo do discurso são, por definição, parcialmente iguais (na medida em que pertencem ao mesmo universo) e parcialmente diferentes (é essa diferença parcial que nos faz distinguir um termo do outro; caso contrário, não teríamos dois, mas um só e mesmo elemento); assim, a noção de função se identifica com a noção de estrutura, de relação ou de estrutura elementar da significação..."(idem ibidem).

A categoria de funcionalidade permite operar, nas linguagens documentárias, a rede de relações entre os termos - descritores e não-descritores. Assim, o significado de cada descritor será dado relativamente a outros descritores. A indicação dos elementos parcialmente iguais e parcialmente diferentes é passível de ser realizada através da hierarquia que, ao estabelecer as oposições, permite estabelecer relações de termos por implicação estrita ou por uma relação todo/parte.

A propriedade da funcionalidade liga-se à propriedade da unidade: "uma estrutura nos aparece como una por ser um universo ou categoria constituída, $S$, pela articulação de duas partes constituintes complementares $s 1$ e $s 2$ " (idem ibidem).

Uma linguagem documentária configura uma unidade a partir da oposição básica estabelecida de início (ou sua hipótese). A partir dessa oposição inicial, revela-se o eixo semântico que determina o vértice principal de leitura constituído de termos-objetos complementares. O exemplo de E. Lopes permite visualizar a estrutura elementar da significação (idem ibidem, p.36):

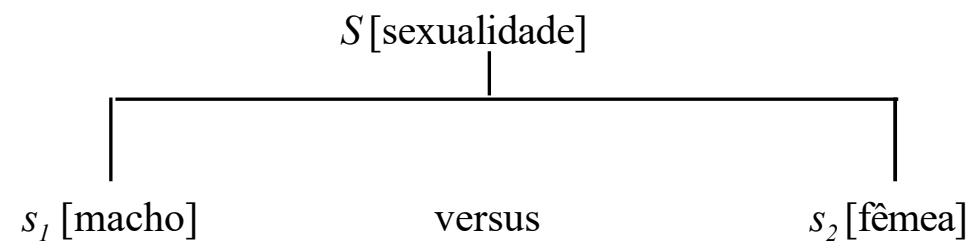

(LOPES, E. (1997). A identidade e a diferença: raízes históricas das teorias estruturais da narrativa. São Paulo: EDUSP, p.36) 
A complementaridade das partes, articuladas por meio de uma diferença no seio de uma totalidade (Saussure) ... confere ao conjunto $S$ a sua coesão sintática e a sua coerência semântica (idem ibidem). "Por outro lado, o conjunto $S$, constituído como uma função por esses constituintes elementares, $s 1$ e $s 2$, tomados como funtivos (Hjelmslev), é uma totalidade - quer dizer, uma estrutura completa em si mesma, em que cada elemento é o que é em função dos demais elementos serem o que o são" (idem ibidem).

A noção de totalidade configura não apenas um mero conjunto, porém uma linguagem documentária coesa, definível em si mesma, a partir da articulação entre seus descritores. A totalidade (e a unidade) realizam um sistema de significação.

A propriedade da transformabilidade prevê que "o texto não pode, enquanto estrutura, ser trabalhado como estático; ... é uma estrutura em perpétua mutação, uma totalidade estruturada que continua sendo, ao mesmo tempo, estruturante - em perpétuo devir, em incessante processo de transformação ${ }^{17}$ " (idem ibidem).

Esta propriedade é, a primeira vista, de difícil operacionalização para as linguagens documentárias, uma vez que ao propor uma estrutura para uma linguagem documentária, considerando o seu caráter de "construção", fornecemos um modelo a partir do qual todos os textos deverão ser lidos. Devemos, entretanto, salientar dois aspectos: primeiro que, do ponto de vista semiótico, o sentido dos descritores não está nunca completamente dado: analisada como interpretante - mais do que código - uma linguagem documentária continua desencadeando a semiose, razão pela qual a idéia de transformabilidade não pode ser totalmente descartada. Enquanto hipótese, a linguagem documentária funciona tal qual um operador de sentido: sua leitura e interpretação podem pressupor um quadro de referência comum - que normalmente tenta-se explicitar através das oposições, definições etc. - porém essa não é uma garantia de interpretação unívoca. Segundo, que uma proposta de linguagem documentária é sempre temporária, enquanto fruto de uma construção que tem como referência universos delimitados. Uma vez que os universos de referência também conhecem o seu desenvolvimento, a operação de "reescrita" é fundamental para que se possa dar conta dos aspectos que a primeira versão não contemplou. O reajuste demandará um "novo estado de equilíbrio tão logo uma de suas partes constituintes haja sido modificada" (idem ibidem, p.37). Sua capacidade de ser aplicável à expansão ou alteração do primeiro universo de referência solicita sua constante atualização.

À idéia de transformabilidade se associa a propriedade de regulatividade, que dá conta da

$17 \mathrm{O}$ texto de $\mathrm{E}$. Lopes a que nos referimos dirige-se, mais exatamente, à análise literária. Apesar das diferenças de objetivos, acreditamos que é possível fazer uma analogia com a atualização das Linguagens Documentárias. 
reacomodação interna das regras de estruturação (idem ibidem). Ao contrário do que ocorre com as línguas naturais, onde essa propriedade - como a anterior - se dá pela própria natureza da língua, nas linguagens documentárias o rearranjo deve ser feito a partir de regras determinadas, muito embora conserve-se, a exemplo do que ocorre nas línguas naturais, o sema, como núcleo a partir do qual a introdução de novos elementos deve ser realizada.

\subsection{Signos lingüísticos e signos documentários}

Os signos lingüísticos são instituídos a partir de convenções. Para Saussure, são o resultado de uma reunião arbitrária, não motivada por necessidade de ordem natural, entre significante e significado. Isso exclui, por princípio, qualquer referência às coisas da realidade, sendo a relação significado significante eminentemente cultural. Os signos lingüísticos são, pois, resultantes de práticas culturais, sendo que "o que o signo lingüístico une não é uma coisa e um nome, mas um conceito e uma imagem acústica” (SAUSSURE, 1972, p.98 apud LOPES, 1997, p.100).

A primeira decorrência dessa afirmação evidencia o caráter não-representacional e antinomenclaturista da teoria saussuriana. De fato, os signos não são meros rótulos que se pregam às coisas que designam, rejeitando-se, pois, quaisquer identificações do referente com a coisa, característica do pensamento dos semanticistas realistas: "a língua não representa algo já feito, anterior a ela: o mundo: ao contrário, a primeira função da língua é criar a realidade para uma comunidade (criá-la ao modo semiótico, recortada em segmentos próprios pela experiência coletiva e assim "significada"... (idem ibidem, p.100-101).

Conseqüentemente, confirma-se que as propostas de linguagens documentárias são apenas hipóteses de organização, sendo seus descritores não 'etiquetas', mas o resultado de uma construção julgada pertinente ou adequada para significar, de certo modo e nos limites de um contexto, segundo uma definição inicial.

A pontuação "acústica" da proposta saussuriana encaminha a uma definição de signo do ponto de vista do destinatário, ou seja, "quem vai dizer o que um signo é, o que ele significa, é o ouvinte (enunciatário), não o falante (enunciador)" (idem ibidem). Isso contraria, portanto, as propostas semânticas tradicionais fundamentadas a partir enunciador (LOPES, 1997, p.100).

O estatuto construído das linguagens documentárias não elimina o caráter construído da informação. Não sendo um dado, mas um ponto de partida para a análise ou interpretação, os elementos de uma linguagem documentária funcionam enquanto signos atualizáveis pelos usuários para constituir informação. À primeira construção sobrepõe-se, necessariamente, uma segunda construção. 
O alcance do termo "acústica" inclui uma clara noção do caráter de competência da langue, pois, para Saussure, "a imagem acústica é por excelência a representação natural da palavra enquanto fato de língua virtual, e fora de qualquer realização pela parole (SAUSSURE, 1972, p.98, nota 1 apud LOPES, 1997, p.101).

Ao contrário do que ocorre com a língua, entretanto, o uso das linguagens documentárias não remete apenas à competência da langue, já que, enquanto sistema 'construído', seu sistema de relações não é virtual, o que solicita o conhecimento de regras explícitas de funcionamento.

O caráter do signo lingüístico é radicalmente arbitrário, uma vez que a determinação do plano de conteúdo varia conforme os distintos contextos de ocorrência. Os valores do signo lingüístico são, assim, determinados contextualmente: "valor = significação contextualmente configurada". O único valor não inteiramente arbitrário, segundo Saussure, é o símbolo (LOPES, 1997, p. 101).

A construção do signo documentário, embora conserve a idéia de arbitrariedade do signo lingüístico (enquanto primeiro código a partir do qual as linguagens documentárias se realizam), aponta para uma preponderância do significado sobre o significante: escolhe-se o significante tendo como referência um significado estabelecido, sob uma determinada ótica, num determinado domínio. A relação significante/significado (enquanto um segundo código) passa a ser motivada, ou seja, tem uma referência concreta no sub-código lingüístico relativo ao domínio de especialidade. Não é a unidade da língua natural (correspondente a uma unidade do léxico da língua, de dicionário) que interessa à Documentação, mas uma unidade de uma língua de especialidade, a partir da qual se elege um significado específico. Porém, do mesmo modo que na língua, o que une significado e significante não é uma coisa, mas uma imagem ou conceito da coisa. A experiência significada resulta da prática de uma segmentação ocorrida na área de especialidade. A essa prática se soma outra: na sua função de representar documentariamente (e de constituir informação), o signo documentário reporta-se àquilo que transforma o conceito da área de especialidade, em informação.

Através do uso da noção de competência da língua, entretanto, viabiliza-se o acesso a esse sistema 'motivado'. Tal como a língua de especialidade, uma linguagem documentária não pode prescindir de elementos da língua natural - sem os quais seria extremamente hermética e mereceria a designação de Linguagem Artificial. Através de sistemas de equivalência, opera-se a compatibilização da linguagem natural para a linguagem documentária e vice-versa.

A noção de valor é essencial, pois, para o estabelecimento do signo lingüístico e do signo documentário. Enquanto unidade positiva e negativa, define o signo lingüístico no seio do sistema da langue e o signo documentário no interior da linguagem documentária, consideradas aqui as referências que empresta das línguas de especialidade. 
No interior da língua, o valor é paradigmático é "estocado em competência”, ou seja, em estado de dicionário. Realizado na parole, pode situar-se em infinitos contextos, acarretando a transformação do sentido em estado de dicionário. Soma-se, então, ao valor paradigmático, um "valor sintagmático", o que mostra que a língua não é uma simples nomenclatura. "O valor paradigmático, do signo da langue, é inalterável; mas se ele se mantivesse inalterável na parole, acabaria por reduzir a língua a uma simples nomenclatura e as palavras a rótulos das coisas às quais designam" (idem ibidem, p.102-103).

Já nas linguagens documentárias o valor paradigmático deve ser explicitamente colocado, restringindose sua interpretação aos limites do contexto enfocado. Esse valor paradigmático ‘explicitado' nas linguagens documentárias, embora encaminhe a interpretação das mensagens documentárias, não se reduz, como na língua, à nomenclatura (mesmo que em alguns pontos de sua estrutura possa se valer de nomenclaturas estabelecidas), uma vez que remete às áreas de especialidade - e indiretamente aos seus discursos - as condições para a construção de seu sentido. De fato, os signos documentários são expressão de recortes operados sobre domínios específicos, significando por força da construção consubstanciada pela rede de relações que se define pela presença ou ausência de traços a serem considerados pertinentes para o estabelecimento de um sistema de significação próprio. É isso que permite afirmar que uma linguagem documentária representa informação. Existirão tantas linguagens documentárias para o mesmo domínio quantos forem os valores selecionados para a construção da rede de relações. Como o afirmou Greimas, "a língua é uma rede de relações negativas e não uma rede de relações" (GREIMAS, 1986, apud LOPES, 1997, p.104) simplesmente.

"Do ponto de vista paradigmático, o elemento de um conjunto-universo (um sistema ou uma classe) é tudo aquilo que os demais elementos do mesmo universo não são" ... "Do ponto de vista do valor sintagmático, um elemento de um processo de fala é tudo aquilo que os demais elementos do seu contexto dizem que ele é" (idem ibidem, p.105).

Se é possível definir as unidades das linguagens documentárias do ponto de vista de seu valor paradigmático, o mesmo não se pode afirmar em relação à sintagmatização, já que não se pode pretender que a combinação de seus elementos se dê tal qual nas línguas naturais. Está ausente nas linguagens documentárias a característica da produtividade, o que determina que as combinações sintagmáticas são restritas e reduzidas.

Enquanto sistema modelizante secundário, embora o valor dos signos seja construído, mais do que "estocado em competência" (para funcionar como sistema de significação que pretende representar a informação), ao remeter a outros sistemas de significação (para falar dos domínios), as linguagens documentárias permitem escapar, de certo modo, à condição de estado de dicionário - e caminhar, indiretamente, para a sintagmatização. 
A partir da perspectiva semiótica a semiose documentária é, de certa forma, controlada. Mas como opera sobre linguagem, é impossível falar em monossemia e em univocidade total de significação. Exemplo disso está na interpretação de "Casados"(LARA, 1993). Definido a partir da lei, a oposição à "Não casados" permite relacionar outros termos que se limitam reciprocamente: Divorciados, Separados, Concubinos etc. O valor próprio de cada um desses termos é garantido pela oposição: analogamente ao exemplo de Saussure (redouter, craindre, avoir peur), se "casado" não existisse, todo o seu conteúdo iria para os seus concorrentes (SAUSSURE apud LOPES, 1997, p.105).

Do ponto de vista sintagmático "Casados" poderia ser combinado à "População de 15 anos", (numa equação de busca formulada ao sistema documentário, que acaba por extrapolar o sentido de dicionário para configurar uma prática social que, embora amparada por lei, pode ser analisável também fora desse âmbito (como por exemplo, das conseqüências biológicas ou sociais).

\subsection{Sintagma e paradigma}

As noções de valor paradigmático e valor sintagmático permitem à Lingüística estabelecer os conceitos de eixo paradigmático e eixo sintagmático, paradigma e sintagma.

O que caracteriza um signo lingüístico "é a linearidade de seu significante: desenvolvendo-se unicamente no tempo, apresenta características que toma do tempo: a) representa uma extensão; b) essa extensão é mensurável em uma única dimensão: é uma linha" (SAUSSURE, p. 103 apud LOPES, 1997, p.106).

Por um lado, "o signo mantém relações paradigmáticas com outros signos - relações de diferença, semelhança, inclusão, implicação, pressuposição etc. De outro, numa frase (cadeia), um signo pode combinar com alguns signos e não com outros. Esta relação, dita sintagmática, permite ao signo combinar com outros signos e integrar o discurso" (TÁLAMO, 1997, p.6).

"Um paradigma é uma classe de elementos que podem ser colocados no mesmo ponto de uma mesma cadeia, ou seja, são substituíveis ou comutáveis (MATOSO CÂMARA, 1964, p.236 apud LOPES, 1987, p.90). Os elementos da língua não aparecem isolados em nossa memória; ao contrário, eles participam de classes, ou conjuntos de elementos que têm um traço lingüístico comum. A partir desses traços estabelecemos as diferenças e as igualdades

entre os elementos e as classes. É, portanto, a partir das correlações que estabelecemos entre os elementos de uma mensagem e os elementos da nossa memória da língua que podemos dar sentido a uma mensagem. "Nenhuma mensagem tem sentido em si mesma" (LOPES, 1987, p.90). 
Diz-se, portanto, que o paradigma de um signo estabelece as relações in absentia entre as unidades, já que a classe, embora delimite a significação de seus elementos, não se encontra materialmente dada (TÁLAMO, 1997, p.6).

Para a Documentação a noção de paradigma é mais facilmente entendida quando examinamos a noção de categoria oriunda da lógica. Ao selecionarmos os elementos que formarão uma classe, ou uma categoria e estabelecermos relações entre esses elementos, realizamos uma escolha a partir da pertinentização de determinados traços. Procedendo desse modo, automaticamente estaremos excluindo todos os elementos que não têm o traço selecionado. Por exemplo, ao selecionar Biblioteca, do ponto de vista da especialização de seu acervo, poderemos derivar bibliotecas especializadas e bibliotecas gerais. Porém, ao acrescentar a característica "pública", excluiremos do conjunto as bibliotecas especializadas ou gerais privadas.

A construção do eixo paradigmático das linguagens documentárias evidencia um modo de caracterizar a informação, tornando explícita, através dos elementos presentes na linguagem, aqueles ausentes, em função da escolha efetuada. Neste caso específico é possível realizar uma aproximação entre paradigma enquanto conceito da langue à paradigma no sentido kuhniano. Dito de outro modo, cada linguagem documentária representa uma opção de leitura de um determinado domínio, uma hipótese de organização que exclui outras tantas hipóteses.

A construção de uma linguagem documentária realiza, por outro lado, uma espécie de explicitação do que, nas línguas naturais, é memorizável na língua (acrescentando-se características pertinentizadas a partir da fonte 'língua de especialidade'). Através de um processo analítico e a partir de um ponto de vista, selecionamos e registramos as unidades que associamos a partir da presença de determinadas propriedades (segundo o parâmetro escolhido para falar de propriedades), de modo a “materializá-las”. A partir dessa seleção, organizamos relacionalmente os termos completando, se for o caso, o registro efetuado. As propriedades não são aleatórias, mas definidas a partir do ponto de vista selecionado, o que permite coletar, no interior do domínio de referência, os termos que integrarão a linguagem documentária. Como já havíamos afirmado, não é, pois, exatamente no 'tesouro da língua' que colhemos as unidades, mas, principalmente, em um de seus subconjuntos - aquele relativo ao domínio selecionado.

Em razão da linearidade da fala, só podemos utilizar um elemento lingüístico de cada vez, o que significa que a seleção de um membro do paradigma exclui, automaticamente, os demais. As correlações paradigmáticas se baseiam na similaridade entre componentes da mesma classe. Ao longo do eixo vertical a similaridade mobiliza substituições de elementos equivalentes, similaridade de sons e similaridades de conteúdo (paradigmas de conteúdo: palavras associadas a partir de traços semânticos comuns). As escolhas, no eixo paradigmático, se dão, dentro de certos limites, 
"ao arbítrio do enunciador, durante o ato da enunciação" (LOPES, 1997, p.109). No universo das linguagens documentárias, as escolhas são mobilizadas pelas instituições.

A cadeia formada pelos significantes é fundada na seqüencialidade da fala. A dependência funcional entre dois elementos seqüenciais dentro de uma mesma cadeia tem o nome de relação sintagmática, sendo sintagma o conjugado binário que essa relação constrói (idem ibidem, p107). "A relação sintagmática responde pela combinação dos signos efetivamente presentes numa cadeia verbal, falada ou escrita ... A relação sintagmática é uma relação de coexistência, que se dá in praesentia" (TÁLAMO, 1997, p.7).

Nas linguagens documentárias as opções de sintagmatização são restritas às regras de combinação previstas pela linguagem documentária: mais amplas em alguns casos - como no SYNTOL Syntagmatic Organization Language - mais restritas nos sistemas de classificação (Add notes, adição de complementos ao tema) e mesmo nos tesauros (lógica booleana).

Uma vez que um signo tem parte da significação determinada pela classe de signos de que participa e por outro, da combinação dos signos entre si, é possível afirmar que, no caso das linguagens documentárias, a significação não se dá no mesmo nível das mensagens discursivas, uma vez que não é potente seu eixo de sintagmatização. O valor é o "sentido local produzido pela intersecção dos dois eixos do discurso, o paradigmático e o sintagmático" (LOPES, 1997, p.114), ou seja, ele não se determina unicamente a partir de uma relação paradigmática, mas também na cadeia do discurso.

Nesse sentido, não há mensagens documentárias análogas às mensagens lingüísticas. Se é possível falar de mensagens documentárias, sua compreensão está baseada em regras restritas e dependentes da sua condição de sistema semiótico secundário. A sintagmatização é, ou alcançável indiretamente - consubstanciada que é nos discursos da especialidade - ou integrada, a seu modo, à linguagem propriamente dita, através de mecanismos sintáticos próprios.

\subsection{Plano de expressão/ plano de conteúdo}

No domínio da linguagem não há "coisas que sejam naturalmente dadas"; logo, não há substância: é o ponto de vista que cria o objeto" (SAUSSURE apud GODEL, 1975 apud LOPES, 1997, p.120). "A língua é forma e não uma substância" (SAUSSURE, 1972, p.169 apud LOPES, 1987, p.94). A partir dessa afirmação Hjelmslev postula que o sistema dos significantes constitui o plano de expressão e o sistema de significados o plano de conteúdo. A língua, então, se define como "uma forma específica organizada entre duas substâncias: a do conteúdo e a da expressão..." HJELMSLEV, 1971, p.44 apud LOPES, 1987, p.94). "Embora a substância do conteúdo e a 
substância da expressão sejam as mesmas para todas as línguas naturais, a forma do conteúdo e a forma da expressão diferem de língua para língua" (LOPES, 1987, p.95).

O plano de expressão e o plano do conteúdo são concebidos em função de dois strata que se opõem, no interior do qual se explicita a dicotomia forma/substância, conforme abaixo:

\begin{tabular}{|c|c|c|c|}
\hline \multirow{2}{*}{$\begin{array}{l}\text { Plano do } \\
\text { Conteúdo }\end{array}$} & Substância do Conteúdo - (SC) & \multirow{4}{*}{$\begin{array}{l}\text { (= designatum) } \\
(=\text { significado }) \\
(=\text { significante })\end{array}$} & \\
\hline & Forma do Conteúdo - (FC) & & \multirow{2}{*}{ SIGNO } \\
\hline \multirow{2}{*}{$\begin{array}{l}\text { Plano da } \\
\text { Expressão }\end{array}$} & Forma da Expressão - (FE) & & \\
\hline & Substância da Expressão - (SE) & & \\
\hline
\end{tabular}

(LOPES, E. (1987). Fundamentos da lingüística contemporânea. São Paulo : Cultrix, p.95).

O designatum e o som são duas substâncias amorfas a partir da qual a língua cria formas. “... São veículos aos quais se imprime uma estrutura abstrata, peculiar a cada língua, operando a transformação da substância em forma"...A substância do conteúdo e a substância da expressão são praticamente as mesmas para todas as línguas naturais, mas a forma do conteúdo e a forma da expressão diferem de uma língua para outra (idem ibidem).

Por exemplo: "Por trás dos paradigmas que, nas diferentes línguas, são formados pelas designações de cores, podemos, por subtração das diferenças, isolar um ... contínuo amorfo: o espectro das cores no qual cada língua estabelece arbitrariamente suas fronteiras" (HJELMSLEV, 1975, p.57). A não concordância entre as fronteiras das designações das cores pode ser visualizada:

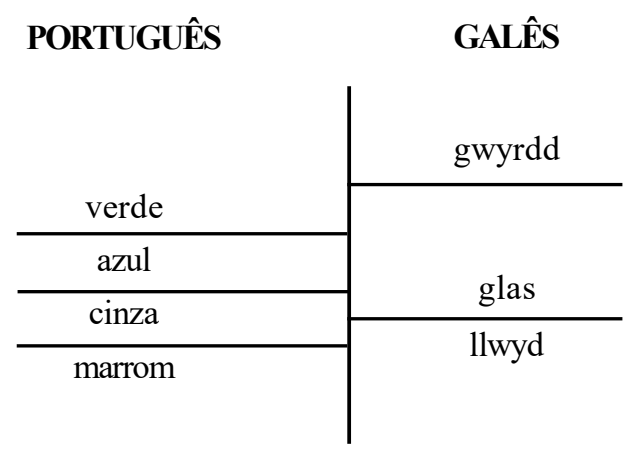

(HJELMSLEV, L. Prolegômenos a uma teoria da linguagem. São Paulo ; Perspectiva, 1975. p.58). 
Ou no exemplo citado por Lyons e reproduzido por E. Lopes:

$\begin{array}{ll}\text { (esp.) } & \text { no hace calor } \\ \text { (fr.) } & \text { il ne fait pas chaud } \\ \text { (al.) } & \text { es ist nicht warm } \\ \text { (port.) } & \text { não faz calor }\end{array}$

Tais frases, embora "tenham o mesmo designatum, o mesmo "sentido", esse sentido amorfo está realizado de forma diferente nessas línguas" (LOPES, 1987, p.96). Não há sujeito no espanhol e em português, que aparece em francês e alemão. O elemento que indica a negação é colocado no eixo sintagmático, em posição diferente: no início (no espanhol e no português, e no meio, no francês e no alemão. No francês, diferentemente das outras línguas aqui citadas, a negação é dada por dois morfemas ... (idem ibidem).

Esse exemplo, como aquele de Hjelmslev, mostra que cada código lingüístico tem uma maneira peculiar de realizar, quer a combinação sintagmática, quer a associação de elementos dentro de classes paradigmáticas. Cada língua estabelece suas fronteiras na 'massa amorfa do pensamento', enfatizando valores diferentes e colocando o centro de gravidade em destaques diferentes (HJELMSLEV, 1975, p.57).

Desdobrando-se no universo da linguagem, as linguagens documentárias herdam os valores da língua. Sobrepõem-se, entretanto, aos valores configurados pela língua, aqueles relativos ao modo de organizar as descrições dos objetos sobre os quais se volta. Dito de outro modo pode-se identificar, nas linguagens documentárias, um plano de expressão e um plano de conteúdo: o plano de expressão pode ser definido como as formas significantes, os descritores, selecionados para representar os conceitos (ou o plano de conteúdo). Os descritores constituem as unidades preferenciais, utilizadas não só a partir da "garantia literária" (termos que são mais freqüentemente utilizados pela literatura do domínio) como em função da freqüência com que os termos são demandados pelos usuários. Do ponto de vista do conteúdo, a preferência se consubstancia enquanto transformação do conteúdo de conceitos retirados de domínios, em conteúdos informacionais. Preferindo determinadas expressões e delimitando, assim, determinados conteúdos, a linguagem documentária pretere expressões e conteúdos registrando, a seu modo, uma forma de organizar a informação. Equivalências sinonímicas ou quase-sinonímicas permitem, por outro lado, identificar as formas que, a rigor, ficam fora de seu plano de expressão (e, conseqüentemente, de seu plano de conteúdo) propriamente dito.

Ao realizar essa seleção à base de expressões preferenciais uma linguagem documentária delimita um dado sistema de significação. Tal sistema de significação responde pelo modo como delimita a 
informação. Do mesmo modo que a relação plano de expressão / plano de conteúdo na língua, o sistema de significação das linguagens documentárias sugere um modo de leitura do domínio-objeto.

O entendimento da língua como forma leva a Documentação a perceber que a tradução de linguagens documentárias não se realiza sem adaptações. Exemplo já citado em nossa dissertação de mestrado mostra que a tradução do Thesaurus Popin - do espanhol para o português - não podendo contemplar o termo "cortiço", mas apenas "favela", que corresponde aproximadamente a "barrio de tugurios", realizou uma equivalência inadequada entre "cortiço" e "favela", remetendo o primeiro ao segundo termo (THESAURUS POPIN, 1986, p.53).

\subsection{Sincronia e diacronia}

A dicotomia estruturalista permite considerar a língua a partir do eixo de simultaneidades (sincronia) ou do eixo de sucessividades (diacronia). No primeiro caso, considera-se o funcionamento da língua num determinado momento do tempo, enquanto sistema estável (descrição sincrônica ou estrutural); no segundo caso, a língua é analisada na sua evolução (descrição diacrônica ou histórica).

O estabelecimento dessa dicotomia permite separar os fatores internos da língua, dos externos ou histórico-culturais. Do ponto de vista sincrônico, reafirma-se que nenhum elemento da língua pode ser considerado como fato isolado: surge, então, a noção de sistema (equivalente à estrutura), permitindo à Lingüística o estudo relacional dos elementos lingüísticos enquanto coexistentes.

Já do ponto de vista diacrônico, as posições entre lingüistas variam quanto à tarefa de estudar a evolução da língua: para uns, o estudo diacrônico dá conta da alteração de elementos isolados da língua; para outros, a mudança da língua representa mudança de sistemas, não de elementos isolados, considerando-se, portanto, a descrição sincrônica das etapas lingüísticas como condição prévia e necessária para sua análise diacrônica (LOPES, 1987, p.74-75). Outros lingüistas, ainda, vêem a diacronia como algo que não é exterior à sincronia, mas que sobrevive dentro da sincronia.

"Um estado da língua é, antes de tudo, o resultado de um certo equilíbrio entre as partes de uma estrutura... A solidariedade de todos os elementos faz com que, uma vez que se afete um de seus pontos, o conjunto das relações seja colocado em questão, produzindo, cedo ou tarde, um novo arranjo... A análise diacrônica consiste em estabelecer duas estruturas sucessivas, exibindo suas relações, para revelar que partes do sistema anterior foram afetadas ou ameaçadas, e de que modo se preparava a solução encontrada no sistema anterior. Eis como se dissolve o conflito ... entre diacronia e sincronia" (BENVENISTE, 1966, p.9 apud LOPES, 1987, p.76). 
Não existe, de fato, sincronia pura, pois coexistem no interior de cada sistema estágios de evolução diferentes: um código constitui-se como interação de subcódigos (mais antigos e mais recentes) e essa é uma propriedade das línguas, permitindo caracterizá-las como mecanismos dotados de produtividade (LOPES, 1987, p.76).

Para a Documentação, o ponto de vista sincrônico permite reconhecer a possibilidade de estudar as linguagens documentárias enquanto estruturas em si mesmo. Reconhecendo o princípio da estrutura “duas relações se apresentam como fundantes: a de oposição (diferença) e a de identidade" (TÁLAMO, 1997, p.8-9). As diferenças são realizadas sincronicamente, como frutos do ato de percepção: "perceber é ... apreender diferenças; é através das diferenças que o mundo organiza-se em formas, à nossa frente" (LOPES, 1987, p.312). Como afirmou Lévi-Strauss "se a realidade, o mundo, o objeto do conhecimento, enfim, se apresentasse sob a forma de um continuum homogêneo, aos olhos do sujeito conhecente, esse objeto não teria nenhum sentido: a significação manifesta-se, pois, a partir da percepção de descontinuidades, ou desvios diferenciais"(LÉVI-STRAUSS apud LOPES, 1987, p.312).

Do ponto de vista sincrônico, as linguagens documentárias são analisáveis enquanto construções privilegiando as relações internas entre seus elementos. Analisam-se, portanto, as formas de expressão e conteúdo visando apreender as identidades e as diferenças simultaneamente estabelecidas - identificando-se, pois, os seus parciais iguais (operação de conjunção) e seus parciais diferentes (operação de disjunção).

O vínculo estabelecido entre os "termos-objetos" que se requerem mutuamente através de seus parciais iguais e parciais diferentes, constitui uma relação, do que decorre uma primeira definição de Greimas para estrutura: "presença de dois termos vinculados por uma relação" (GREIMAS apud LOPES, 1987, p.312) já apontada. Cada termo da relação possui dois elementos - um

conjuntivo e outro disjuntivo. A estrutura, pois, revelada pela análise sincrônica, permite reafirmar que, do mesmo modo que na língua, nas linguagens documentárias as coisas não são naturalmente dadas: não há substâncias; é o ponto de vista que cria o objeto.

Na perspectiva diacrônica, é possível analisar as linguagens documentárias considerando sua evolução no tempo. É essa análise que permite identificar, historicamente, os valores subjacentes a cada proposta de organização.

\subsection{Langue/parole, forma e substância}

Para Saussure, a linguagem humana é uma abstração, uma capacidade: "ela consiste na capacidade que o homem tem de comunicar-se com os seus semelhantes através de signos verbais" (LOPES, 
1987, p.76). Por langue, entende-se o sistema da língua, ou o conjunto das regras fonológicas, morfológicas, sintáticas e semânticas que determinam o emprego dos sons, das formas e relações sintáticas necessárias para a produção do significado (idem ibidem, p.76-77). A langue é um sistema que existe além do indivíduo, sendo definida pelo grupo social a que ele pertence. É, por essa razão, institucional: “a língua é um conceito social”" (SAUSSURE, 1972, p.37 apud LOPES, idem ibidem). Enquanto um bem social, a língua é um contrato coletivo, preexistindo e subsistindo a cada um de seus falantes considerados individualmente.

Já a parole constitui a língua posta em ação pelos falantes. A característica essencial da parole é a liberdade de combinações (SAUSSURE, 1972, p.192 apud LOPES, idem ibidem). "A parole aparece aí como uma combinatória individual que atualiza elementos discriminados dentro do código: assim, a langue é a condição para a existência da parole, exatamente como a sociedade é a condição para a existência do indivíduo" (LOPES, 1987, p.77). Para Saussure, "a linguagem é a soma da língua e do discurso; a língua é a linguagem menos o discurso, E a parole se assimila à natureza do acontecimento (RICOEUR, 1967, p.808-809 apud LOPES, 1987, p.77-78).

Assim como Hjelmslev rebatizou a dicotomia langue/parole por esquema/uso, Jakobson fala de código/mensagem. Os conceitos de langue e parole englobam e antecipam os de competência e performance de Chomsky (LOPES, 1997, p.128). A langue é o social, a parole o individual. A parole é a realização individual de uma língua social. A relação parole versus langue é necessária, "pois é através do consenso coletivo, no julgamento das identidades a que podemos reduzir as diferenças da fala, que se garante a condição supra-individual da parole" (idem ibidem, p.129). Porém a "relação langue versus parole é não-necessária, ... ela não é internamente requerida pelo sistema mesmo da língua, pois que, se a função da língua é interpretar a realidade para uma dada comunidade, essa interpretação varia de uma para outra coletividade, em função mesmo da variação das línguas". A relação língua-realidade é arbitrária, por recortar e aplicar-se a experiências histórico-culturais diferentes. (idem ibidem, p.130).

Do ponto de vista das linguagens documentárias é a langue a referência principal, porque ela permite registrar o sistema, configurado a partir das relações entre seus descritores. Não ocorre o mesmo com a parole, já que seu estatuto de linguagem construída interdita a possibilidade de combinações. Se metaforicamente poderíamos estabelecer uma comparação da parole com a possibilidade combinatória entre descritores de uma linguagem documentária - para formar as mensagens documentárias - somos obrigados a reconhecer que essa analogia é bastante imperfeita, pois, às linguagens documentárias faltam os mecanismos de articulação que caracterizam as línguas naturais. Enquanto sistema construído, as linguagens documentárias carecem dessa característica de sistema virtual que é a língua. 
Como observa Granger, "toda linguagem formalizada ... não é mais exata ou exclusivamente uma linguagem, sobretudo se dela for retida sua função de comunicação" (GRANGER, 1974, p.139). As linguagens formalizadas são difíceis de memorizar e o que elas ganham em rigor perdem em eficácia, sendo que na realidade, sua função comunicativa é apenas virtual. Embora as linguagens documentárias não sejam verdadeiramente linguagens artificiais, é fato que elas apresentam um certo nível de formalização. Como nas linguagens formais, nas linguagens documentárias, está ausente uma segunda articulação, sendo que o sentido de suas expressões "é diretamente embreado no sistema dos sintagmas que corresponde ao primeiro nível de articulação das línguas naturais". Além disso, "as línguas formais ignoram os símbolos de 'embreagem' numa experiência vivida', remetendo apenas a uma combinação de regras simbólicas que constitui seu 'objeto' no sentido de Peirce (idem ibidem, p.140-141). A ausência de produtividade que caracteriza as linguagens formalizadas proíbe, portanto, a aproximação.

Considerando todas as diferenças da analogia com as linguagens documentárias, podemos afirmar que, aí, a relação parole versus langue é necessária, pois as combinações a serem estabelecidas o serão estritamente, a partir de regras determinadas e apenas relativamente ao sistema considerado em si. Já a relação langue versus parole estará determinada pelo ponto de vista estabelecido pela linguagem documentária considerada, existindo tantas abordagens - e tantas caracterizações de informação - quantas forem as linguagens documentárias construídas para representar documentariamente o domínio.

Pode-se, ainda, observar a parole na construção das linguagens documentárias do ponto de vista do uso. De fato, as linguagens documentárias devem absorver as variações identificadas na linguagem do usuário, como meio de estabelecer equivalências para o acesso.

A relação língua/realidade é histórica, como a relação língua/fala. Porém, é uma relação arbitrária, porque recorta e aplica-se a experiências histórico-culturais diferentes. A arbitrariedade garante o funcionamento normal da língua como instituição-imutável em sincronia, mas mutável em diacronia. Arbitrário, para Saussure, quer dizer imotivado - definindo uma relação de conveniência figurativa ou imagética entre significante e significado. Saussure, entretanto, distingue entre arbitrário absoluto e arbitrário relativo: "o arbitrário absoluto refere-se à instituição do signo tomado isoladamente"; o arbitrário relativo refere-se "ao signo enquanto elemento de um contexto". O símbolo, para Saussure, tem o caráter de não ser jamais completamente arbitrário...”os símbolos representam noções abstratas (idéias) por meio de objetos materiais que dão dessas mesmas noções uma representação de algum modo mimética, fundada em algum tipo de semelhança entre significante e significado, mas, ao mesmo tempo, sempre deficiente ou parcial em relação ao conjunto das noções simbolizadas... o símbolo não é vazio: ele não é o todo, mas é pelo menos uma parte do todo, que é o conteúdo abstrato com o qual se relaciona" (LOPES, 1997, p.133-134). 
Para E. Lopes, o gráfico a seguir permite configurar visualmente a teoria do arbitrário em Saussure:

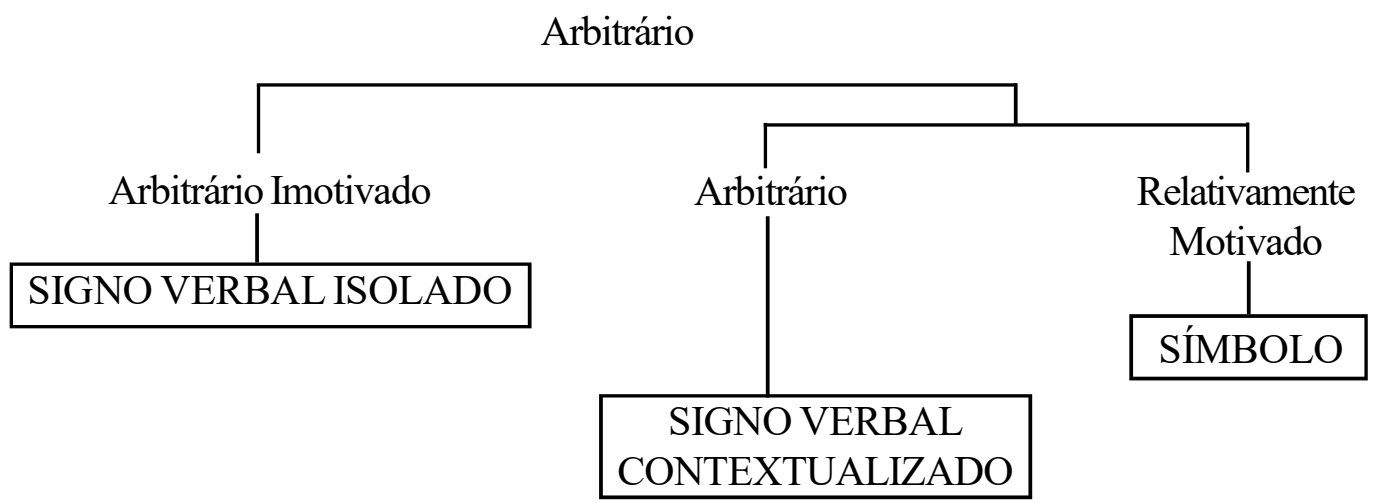

(LOPES, E. (1997). A identidade e a diferença. São Paulo ; EDUSP, p.134: Classificação dos signos segundo a motivação de sua arbitrariedade).

As teses do arbitrário absoluto e arbitrário relativo são transpostas para a Documentação quando se observa que, operando com a linguagem, primeiramente as linguagens documentárias trabalham com signos que são arbitrários. Porém, em função dos domínios - e dos modos de 'recortar' os domínios para constituir informação -, os signos são relativamente motivados. A tese do arbitrário relativo, por sua vez, permite explicar porque a comparação de linguagens documentárias construídas para domínios semelhantes apresenta similaridades, advindas da observação dos mesmos contextos. Variam as formas de descrição em função dos parâmetros de partida para proceder a organização dos termos.

Prevalece nas linguagens documentárias um signo motivado, estabelecendo-se uma preponderância do significado sobre o significante, face aos recortes operados sobre os domínios que constituem seu objeto. Contrariamente ao que ocorre na língua, o significado, na relação significante/significado, tem existência anterior ao sistema.

\subsection{A contribuição da semântica}

A semântica é comumente entendida como a ciência das significações das línguas naturais. A semântica lingüística tem por objeto a significação estabelecida no plano de conteúdo das línguas naturais; a semântica semiótica, a significação dos sistemas sígnicos secundários. A primeira, abrange o estudo do léxico e das estruturas gramaticais (morfologia e sintaxe), porém deve ser abrangida 
pela Semiótica para possibilitar o estudo das relações pragmáticas ${ }^{18}$.

Não se dispõe de um único instrumento para realizar a descrição semântica, já que cada teoria semiótica propõe um método de análise e representação do significado. Para todas elas, no entanto, a representação semântica configura uma metalinguagem. Todas as teorias semânticas têm como objetivo propor regras gerais que condicionam a interpretação semântica das unidades. De uma maneira geral, todo signo lingüístico, ao mesmo tempo que assegura a relação entre um conceito e uma imagem acústica, refere-se à realidade extra-lingüística. Os diferentes enfoques das teorias semânticas dizem respeito ao modo de abordagem das relações entre significante, significado e referente extralingüístico.

A circunscrição das preocupações da lingüística saussuriana ao sistema poderia colocar em dúvida a existência de uma semântica estruturalista a partir da definição de semântica de Carnap, como “teoria das relações entre uma língua... e aquilo que a língua permite falar" (CARNAP, 1956, p.233 apud DASCAL, p.25).

De fato, para a semiologia saussuriana, não é em razão da ligação intrínseca entre significado e significante que os signos significam, mas pela convenção que os une. O princípio da arbitrariedade exclui qualquer estudo dos tipos de ligação que unem significantes a significados.

Já a classificação peirceana dos signos permite incorporar um referencial extralingüístico, já que a semiose, processo pelo qual qualquer coisa age como signo, envolve um Representamem, primeiro termo de uma relação triádica, cujo segundo termo é seu Objeto e um terceiro, que é seu Interpretante. Dito de outro modo, um signo tem três referências: "primeiramente, ele é um signo para algum pensamento que seja que o interprete; em segundo lugar, ele é signo de algum objeto que, dentro desse pensamento, é equivalente; terceiro, ele é signo em algum aspecto ou qualidade, que estabelece uma conexão entre ele e seu objeto" (PEIRCE, 5.283 apud DASCAL, 1978, p.20).

A possibilidade de uma teoria semântica de base saussuriana poderia ser explicada a partir da divisão da semântica em teoria da extensão (ou teoria da referência) e a teoria da intensão (ou teoria do significado). A definição de semiose distingue entre objeto e interpretante do signo,

\footnotetext{
18 A denominação semântica semiótica é redundante, uma vez que o universo do sentido é uno (LOPES, 1987, p.233). Para E. Lopes, hoje costuma-se separar a semiologia, teoria geral dos signos, da semiótica, teoria da significação. As duas disciplinas têm sempre em comum as "linguagens", e daí a aproximação com a lingüística, disciplina que estuda as "línguas naturais". É com Peirce que se reconhece que todo pensamento constitui um signo e participa em essência da natureza da linguagem (LOPES, 1997, p.30, 32). Para o autor, a distinção entre uma e outra é um problema de natureza terminológica, tendo-se fixado "semiótica" como a denominação última e definitiva. Na prática, entretanto, continuam convivendo os dois termos, sendo que alguns autores estabelecem diferenças entre um e outro.
} 
acolhendo, pois, essa possibilidade de divisão da semântica, o que não acontece com a semântica de inspiração saussuriana que rejeitará, por princípio, as concepções que definem a significação como uma relação entre signos e coisas.

O paradigma da referência privilegia o extralingüístico. Compreender um enunciado é compreender que existe uma relação entre aquilo que se fala e os objetos, ou seja, entre o enunciado e a realidade. Mais exatamente, compreender um enunciado é conhecer seu significado, ou conhecer as condições de verdade do enunciado. Propõe-se, portanto, uma relação direta entre expressões lingüísticas e entidades extra-lingüísticas, ou seja, uma relação não mediatizada, porque a língua, aqui, não é uma estrutura simbólica que, embora se relacione com a realidade, mantém sua estrutura autônoma.

Tanto na passagem do significante ao conceito, quanto do conceito ao referente, o segundo termo é privilegiado, porque a verdade se define classicamente como adequatio rei et intellectus (RASTIER, 1991, p.82). A teoria da referência é extensional, porque o significado de um termo é dado pela classe de objetos a que ele pertence. Assim, um termo genérico que denota uma classe, denotará os objetos que estão incluídos nessa classe. A classe desses objetos constitui a extensão ou denotação do termo, donde a equação: extensão : denotação :: intensão : conotação.

Porém, uma teoria extensional da significação é mais aplicável às linguagens formais (RASTIER, 1991), já que é problemático operacionalizar o conceito de extensão de forma absoluta uma vez que, além de nem sempre ser possível determinar um conjunto de características aplicáveis ao conceito, podemos ter um mesmo referente relacionado a diferentes significados conotados (conforme o clássico exemplo “estrela da manhã”). Pelo paradigma da referência é possível identificar do que se está falando, mas não como se está falando. A extensão é determinada pela intensão, mas o inverso não é verdadeiro. Na lógica, a extensão sempre determina a intensão, e as propriedades que vão determinar a construção de classes. Porém não é preciso conhecer denotativamente uma classe para lhe conferir uma conotação (ex.: “unicórnio"). A referência estabelece uma relação entre duas ordens de realidade, conceitos e objetos.

Todavia, o papel da linguagem é o de "funcionar como uma instância de mediação entre o homem e o mundo e é essa mesma propriedade, intrínseca à função semiótica, que investe as diferentes práticas sociais do seu papel de códigos e que instaura as unidades desses códigos, os signos. Assim como o signo não é o objeto ou coisa que ele representa, a linguagem não é o mundo; ela é, apenas, um saber sobre o mundo, capaz de fazer-se intersubjetivo e de relacionar consciências. Eis porque só tem sentido falar-se de "objeto" como quadro de 
referência comum ao remetente e ao destinatário da mesma mensagem, isto é, como designatum e não como denotatum" (LOPES, 1987, p.248-249).

Para o paradigma da diferença - que caracteriza a proposta saussuriana - o que o signo une não é uma coisa e um nome, mas um conceito e uma imagem acústica. Este paradigma permite precisar as condições de uma semântica relativista, própria para distinguir as línguas particulares (RASTIER, 1991, p.82). A semântica diferencial permite distinguir entre "relações intra-sígnicas - relações verticais no interior de um mesmo signo entre o significante e o significado -, das relações intersígnicas - aquelas que cada signo mantém com os demais signos presentes no mesmo enunciado" (LOPES, 1987, p.234-235).

De fato, a abordagem das relações intersígnicas permite evidenciar que o significado de um termo não provém de sua natureza, mas da "posição que ele ocupa por referência aos outros elementos co-ocorrentes em seu contexto e, por outro lado, ele depende dos elementos ausentes desse mesmo contexto, mas por ele evocados, na memória implícita da langue" (idem ibidem). A teoria semântica de Saussure é, pois, uma semântica baseada na noção de valor definida relativamente através de oposições.

À semântica diferencial corresponde a teoria do significado(theory of meaning), porque esta privilegia o enfoque das relações entre significantes eles mesmos, já que o sentido não é mais do que o conjunto das relações de sentido (relações de antonímia, sinonímia, hiponímia etc., enquanto relações de oposição, equivalência ou subordinação entre expressões), e não entre expressões e seus sentidos, ou ainda, entre apenas seus sentidos. O papel da semântica seria “a estruturação do sistema de significantes tomados enquanto tais...”(GRANGER, 1968, p.127, apud DASCAL, 1978, p.26).

Porém existe aqui mais que um problema terminológico, uma vez que Lyons não afirma exatamente que a semântica estude as relações entre significantes, mas entre significados. Para ele, o significado é função de situações de comunicação, pressupondo as noções de valor e intenção que tem lugar no próprio discurso. O que "palavras e frases de uma língua significam é, em última análise, tanto teoricamente inexplicável como empiricamente inverificável, exceto em termos do que os locutores dessa língua pretendem dizer ao usar essas palavras e frases" (LYONS, 1977, p.13). A identificação realizada por Dascal de que a semântica de Lyons se resolve entre significantes é resultante do fato de que, para este último autor, o estudo das relações de expressões lingüísticas se desenvolve no interior de conjuntos de lexemas, sem postular qualquer substância conceptual ou perceptual subjacente (LYONS, 1977, p.219). Isso poderia resultar numa limitação da semântica estrutural à sintaxe, já que ela pressupõe uma interpretação tradicional da noção saussuriana de "valor" segundo a qual a identidade de um significante constituiria o "conteúdo" ou o "sentido" de um signo. Admitir que o conceito que constitui o significado de um signo não é dado previamente ao sistema de 
signos implicaria uma redução do campo da semântica estrutural à sintaxe ${ }^{19}$ (SAUSSURE, 1915, p.153-154, apud DASCAL, 1978, p.27)

A partir principalmente de Greimas, a Lingüística amplia seu eixo fundamental de análise deslocando da palavra para o discurso o ponto de partida para a discussão da significação. A apreensão discursivo-sintática põe em evidência as relações de comunicação intersubjetivas, vertente mais profícua do que as propostas de cunho mais taxionômico que caracterizaram os primeiros estudos lingüísticos de base saussuriana. Isso fica mais evidente a partir da análise de Greimas acerca da noção de valor que, associada ao princípio do arbitrário do signo, permitiria explicar a necessidade de considerar o ‘semiológico' como ligado indissoluvelmente à uma função social, uma vez que é, fundamentalmente, convencional e regido por regras.

Para Greimas, o universo de significação se estrutura por oposições que têm um modo de existência independente do seu modo de presença nos atos de comunicação. Existiria, segundo sua concepção, anterioridade da significação relativamente à sua manifestação nos discursos, transcendendo a toda linguagem e se situando no plano da percepção. Parte da semântica geral, a semiologia estaria encarregada de estudar esse "conjunto de categorias e de sistemas sêmicos situados e apreendidos no nível da percepção" (GREIMAS, 1966, p.64, apud DASCAL, 1978, p.28).

O universo imanente da significação pode ser depreendido a partir de dois níveis: o nível semiológico e o nível semântico, que constituem unidades de manifestação de dimensões diferentes e mutuamente independentes. A estrutura semiológica opõe-se ao processo, sendo o primeiro logicamente anterior. "O semiológico é, como a linguagem em geral, apreensível dentro da percepção" (GREIMAS, 1976, p.76). As estruturas sêmicas são anteriores às manifestações semêmicas no discurso. Ao postular o caráter autônomo das significações Greimas confere à semântica a tarefa de descrever a estruturação desse "universo imanente da significação".

A análise sêmica do nível semiológico da linguagem operada pela semântica estrutural constitui recurso fundamental ao entendimento das operações de construção de uma linguagem documentária. No universo semântico, estaria o código, modo de presença e lugar de manifestação. No nível semiológico, ou da percepção (nível pré-verbal) - estariam os conceitos (ou as hipóteses). Os códigos particulares manifestam a estrutura do semiológico no semântico. Nas linguagens

19 A interpretação semântica não é viabilizada apenas pela sintaxe. "O componente sintático funciona como mediador abstrato entre o plano de expressão (componente fonológico) e o plano do conteúdo (componente semântico). Os componentes fonológico e o semântico são encarregados de traduzir o componente sintático. Ademais, a estrutura profunda é instância do componente semântico, não só do sintático, como em Peirce e Morris para quem o componente semântico engloba o sintático. Chomsky, que havia excluído a semântica de sua gramática reformulou sua concepção reconhecendo a impossibilidade de delimitar ou admitir fronteiras entre semântica e sintaxe (LOPES, 1987, p.205-206). 
documentárias as grandes articulações de uma área de conhecimento - buscadas na terminologia - são expressas de forma semântica filtradas pela cultura. A significação, assim, nunca vai estar aí inteiramente, porque tal como as várias linguagens, a linguagem documentária funciona como filtro estruturante. Valendo-se da análise semântica, seria tarefa da Documentação procurar as invariantes (as relações semânticas) para representá-las no linguagem documentária.

Greimas já afirmara a utilidade da análise sêmica nas diferentes aplicações da lingüística, seja na tradução automática, seja na construção de "linguagens documentais" uma vez que ela torna mais fácil "a delimitação das unidades constitutivas da linguagem ... fazendo apreender melhor os modos de sua imbricação (GREIMAS, 1976, p.88). Uma análise sêmica nesses moldes, porém, não apresenta muitas diferenças em relação àquela da procura de universais de interpretação. Ambas são questionáveis como propostas documentárias, porém podem ser utilizadas como instrumentos para a operacionalização de determinadas relações consensuais. Greimas enfatiza o perigo de se pretender obter um número muito restrito de unidades de descrição semântica, bem como alerta para a arbitrariedade pressuposta na aceitação rígida da legitimidade da construção apriorística de uma linguagem descritiva (idem ibidem, p.90). Do mesmo modo, chama a atenção para o fato de que a concepção do postulado da anterioridade das estruturas sêmicas "não é menos contrário a nossos hábitos de pensamento profundamente estabelecidos" (idem ibidem, p.77). Ela é uma construção que utiliza para a descrição o princípio indutivo ("em seu desejo de dar conta fielmente da realidade por ela descrita") e dedutivo (a partir da necessidade de coerência do modelo e de buscar uma generalização aplicável a todo o corpus sob descrição) (idem ibidem, p.92).

A análise sêmica proposta por Greimas distingue dois tipos de unidades de significação: os "semas nucleares"-nós sêmicos, traços distintivos, unidades mínimas de significação-eos "semas contextuais ou classemas", que constituem a contribuição do contexto lingüístico para a determinação do sentido. Esses dois tipos se combinam para constituir os "significados" das unidades de manifestação que são os "sememas" e "metassememas". No nível semiológico da língua estruturam-se os semas nucleares; no nível semântico, os classemas. O nível semântico é orientado para o discurso e dele parece depender; o nível semiológico, ao contrário, tem autonomia radical em relação a toda forma, seja lingüística ou não, de manifestação das significações (DASCAL, 1978, p.28-29).

Para localizar os problemas relativos ao nível semântico Greimas considera o discurso como lugar de manifestação da significação, partindo de uma análise centrada na recepção e transmissão da mensagem, e não na sua emissão (o que implica uma crítica às análises centradas na intencionalidade do locutor). O discurso, assim, é visto não como um desenvolvimento linear, mas como criador de uma hierarquia sintática. Através do discurso, ele sugere localizar a isotopia semântica a partir da redundância das categorias classemáticas, tal como a proposta de Hjelmslev relativa à constatação da redundância das categorias morfológicas. 
De fato, a partir de contextos hierarquicamente superiores, é possível identificar os classemas manifestados (para ver, por exemplo, a diferença entre o cão ladra e o comissário ladra) (GREIMAS, 1976, p.96-97). A identificação da hierarquia de contextos permite estabelecer critérios discriminatórios, sendo os lexemas e o sintagma os contextos mínimos que permitem estabelecer uma isotopia. Essa idéia utilizada muitas vezes de forma intuitiva nas linguagens da Documentação pode agora contar com um parâmetro metodológico.

É lícito propor que as mensagens documentárias originárias de uma linguagem documentária (ou a própria linguagem documentária enquanto estrutura global), tal como as mensagens discursivas (ou os conjuntos significantes de nível maior) são isotópicas(os) quando possuírem um ou vários classemas em comum. Os classemas, que pertencem ao nível semântico, constituiriam as representações de figuras sêmicas dependentes do nível semiológico investidas no discurso (e aqui, na linguagem documentária propriamente dita que, a seu modo, é um discurso ou permite gerar discursos documentários).

Para estabelecer um contexto isotópico a linguagem documentária lança mão dos domínios de conhecimento ou de atividades. A constituição de uma isotopia inicial e das isotopias que se seguem constitui a principal característica das linguagens documentárias estruturadas (o que também explica porque não funcionam de forma eficiente as listas alfabéticas de cabeçalhos de assunto que não possuem qualquer possibilidade de instaurar isotopias por não utilizarem a hierarquia contextual como meio de representar as articulações).

A distinção entre nível semântico e nível semiológico da língua poderia, também, explicar a dificuldade de tradução das linguagens documentárias. No nível semiológico, estariam os conceitos. Nos códigos estariam representadas as relações semânticas a partir da hierarquização contextual. Admitindo-se, todavia, que os conceitos também são modelados nos subcódigos - na terminologia representativa das articulações, por exemplo - remeter-se-ia novamente sua interpretação à codificação da língua sob a ótica dos domínios de especialidade. Entende-se, portanto, que as linguagens documentárias traduzidas apresentam uma deformação proveniente do trânsito não identificado explicitamente entre os dois níveis.

A proposta greimasiana permite explicar, também, a tendência verificada na história dos discursos sobre a representação documentária de encontrar e definir categorias universais de análise. Porém, como nem as línguas, e muito menos as linguagens documentárias, conseguem verbalizar ou descrever toda a riqueza do universo semiológico (admitindo-os como fatos de percepção), sobram sempre resíduos. O inventário possível de categorias nunca será suficiente para dar conta de todas as manifestações passíveis de se realizarem nas diferentes línguas, ligadas que estão aos condicionantes culturais. 
Muitas das categorias admitidas como universais são, de fato, utilizadas na representação documentária quando se trata de remeter a princípios mais estáveis e compartilhados. Um agrupamento geográfico, por exemplo, é um critério útil de ordenação. As categorias gerais, entretanto, constituem um recurso de organização definido a partir do consensual. As categorias propostas pelo CRG (reescritura das categorias aristotélicas), como já mencionamos, nem sempre se mostram suficientes para dar conta dos distintos pontos de vista de análise. De natureza mais lógica do que propriamente semântica, a operacionalização dessas categorias também esbarra com problemas da lexicalização (que igualmente não é homogênea para as diversas línguas). No nível semântico-pragmático são determinadas as categorias mais úteis para a representação de pontos de vista particulares. Mas é difícil afirmar que tais categorias sejam constantes para as diferentes línguas.

A grande contribuição do estruturalismo (e da Modernidade) refere-se à possibilidade de entender que o continuum da realidade estrutura-se na descontinuidade das línguas. Os distintos códigos são estruturados e reestruturados a partir de infinitas possibilidades. Aceitável seria admitir que, ao trabalhar no nível semiológico, as linguagens documentárias estariam trabalhando com conceitos enquanto abstrações que são manifestas, com maior ou menor grau de semelhança, pela maior parte das línguas, lugar da significação que nunca vai se esgotar através dos recortes no continuum da realidade. Já no nível semântico, as linguagens documentárias operariam seu recorte, seja através do código da língua utilizada, seja através dos subcódigos que tornam pertinentes características para as organizações dos domínios.

O desenvolvimento da proposta de estrutura mínima de significação de Greimas (a que já nos referimos anteriormente), também é fundamental para compreender o jogo que se instaura, no processo de construção de uma linguagem documentária, entre a expansão e a condensação. $O$ discurso é, para Greimas, uma hierarquia de unidades de comunicação que se encaixam umas nas outras e que contém, em si mesmo, a negação dessa hierarquia uma vez que as unidades de comunicação de dimensões diferentes podem ao mesmo tempo ser reconhecidas como equivalentes (GREIMAS, 1976, p.97).

O mecanismo da expansão é próprio do discurso, como também o é o de condensação. Uma palavra pode ser explicada por uma seqüência mais ampla, como também é possível, através de uma palavra, designar o que se concebeu sob forma desenvolvida. Essa possibilidade de equivalência, característica do discurso, evidencia uma propriedade metalingüística, e é essa a propriedade assimilada pela Documentação para constituir suas linguagens documentárias. Utiliza-se, na elaboração dessas linguagens, gêneros análogos ao "lexema catalisador" apontado por Greimas, que substituem, a seu modo, definições discursivas: do mesmo modo também são utilizadas as expansões propriamente ditas que constituem o processo inverso. 
A definição discursiva é próxima da definição lógica, porém não é unívoca e limitativa como ela, uma vez que não pressupõe identidade entre os segmentos, mas uma equivalência provisória a partir dos semas comuns aos dois segmentos justapostos. A definição discursiva tem como corolário a condensação (expressa nas linguagens documentárias através dos sintagmas mínimos (ou dos descritores correspondentes aos termos, numa outra terminologia), quer explícitos ou deduzidos a partir da hierarquia), que desemboca, freqüentemente, na denominação. "Esse funcionamento metalingüístico de um discurso que gira perpetuamente em torno de si mesmo, passando sucessivamente de um nível a outro, faz pensar no movimento oscilatório entre a expansão e a condensação, a definição e a denominação" (GREIMAS, 1976, p.101). Porém, é preciso lembrar que todo processo de denominação é mais restritivo do que o de definição, porque ocorre, invariavelmente, um empobrecimento sêmico, o que explica porque falha, muitas vezes, a comunicação documentária centrada exclusivamente na condensação (admitindo-se aqui como produto da condensação os índices, e não o resumo).

Outra importante contribuição de Greimas diz respeito ao estatuto dos classemas como elementos constitutivos do quadro da organização do universo semântico. A possibilidade da definição, de um lado, e de denominação, de outro, de uma única unidade de conteúdo, deve-se à existência de semas idênticos. No processo de constituição de linguagens documentárias essa identificação remete à formação de classes e subclasses (sucessivamente), bem como à integração da sinonímia como meio de inventariar (pelo menos parcialmente) as ocorrências relativas à classemas comuns e unidades isotópicas em relação ao contexto. A sinonímia funciona não apenas como recurso de acesso, mas como meio de registrar a redundância.

Não é possível imaginar, porém, que a recepção de informações via linguagens documentárias seja objetiva, uma vez que é impossível registrar a totalidade de conceitos sobre o mundo (ou o domínio a representar). A apreensão (e construção) da significação procede por identificação de equivalências e por aproximações: "se um semema se define como uma coleção sêmica suscetível de adições semiológicas ..., ele também se caracteriza pela totalidade de suas determinações possíveis, isto é, quer pelo conjunto de qualificações que podemos atribuir-lhe, quer pelo conjunto de predicações que admite" (GREIMAS, 1976, p.122).

Sob esse ângulo, qualquer descrição de conteúdo pareceria impossível, porque a interpretação das definições depende de sua integração num texto. Não se pode esperar que todos os acontecimentos retidos numa descrição sejam previstos, "mas eles nunca são gratuitos". O conhecimento adicional aí passível não está diretamente relacionado (ou não é implicado) pela própria definição, mas depende do contexto global - atualização individual (Benveniste) a partir da experiência colateral (Peirce) - e é nesse ponto que a Documentação recorre à Terminologia para colher seus operadores de sentido. A função de uma mensagem documentária seria a de 
especificar um termo genérico a partir do qual se deduz a informação, mas é importante destacar que a atualização pode desencadear outras informações não isotópicas. O uso de uma definição do tipo semântico-semiótica-pragmática poderia encaminhar uma interpretação desejada.

A hipótese de Greimas é a de que a partir do sema chega-se à descrição de universos mais vastos de significação, o que revela um fundamento epistemológico que atribui às categorias de definições um estatuto apriorístico. A língua é, assim, um sistema imanente, e a língua apreendida, um processo manifestado, existindo entre os universos significantes uma relação de pressuposição recíproca. É de ordem sêmica o conjunto de sistemas; é da ordem do nível semiológico, o conjunto de ordens sêmicas. Se a um universo imanente corresponde um conjunto de categorias sêmicas (ordem sistemática), a um universo de manifestação corresponderia uma combinatória de suas articulações (ordem morfemática). Embora essa relação pressuponha uma afirmação anterior de ordem epistemológica diferente daquela que vimos procurando seguir, é inegável que ela constitui instrumento de operacionalização para a construção de linguagens de representação que procuram articular plano de expressão e plano de conteúdo.

As regras de construção de uma combinatória, por sua vez, relacionam o universo de imanência e o universo de manifestação que embora sejam caracterizados por organizações internas distintas, constituem vasos comunicantes (idem ibidem, p.144). O universo imanente se deixaria reconstruir a partir da manifestação; a manifestação deveria e poderia ser dele deduzida (idem ibidem).

A construção de combinatórias remete, pois, à identificação de categorias sêmicas (subconjunto dos semas nucleares e subconjunto dos classemas), lembrando-se que qualquer unidade de manifestação exige a presença simultânea de, no mínimo, dois semas (tal como a estrutura elementar de significação). Duas espécies de manifestação podem ser combinadas: os sememas e os metassememas:

a) um corpus de metassememas são deduzidos do subconjunto de classemas (na linguagem documentária, às categorias gerais corresponderiam categorias contextualizadas a partir dos domínios);

b) um corpus de sememas é realizado a partir do subconjunto de semas nucleares e classemas (o que corresponderia, nas linguagens documentárias, ao inventário dos descritores contextualizados nas categorias eleitas dos domínios).

A partir dessa concepção de universo semântico, podem ser descritos os níveis semiológico e semântico imanentes. O número de categorias sêmicas varia em função do tamanho e nível de profundidade de tratamento do corpus: maior quando o corpus é pequeno, menor para um corpus que pretende abarcar universos maiores. "À simplicidade do universo imanente corresponde a complexidade do universo manifestado, articulado em sememas: quanto menos combináveis são 
os semas, mais complexa e fastidiosa aparecerá a estrutura morfemática de cada semema" (GREIMAS, 1976, p.145).

Existe, também, uma lacuna entre o conteúdo realizável e o efetivamente realizado. "Se o modelo sêmico de um universo semântico é fechado, seu corpus de sememas é, em compensação, amplamente aberto" (idem ibidem, p.146).

A combinação sêmica que constitui os sememas é de densidade desigual. A combinatória pode produzir a combinação de, no mínimo, dois semas, mas também de várias categorias sêmicas. De fato, é difícil que um destinatário decodifique e aprenda a partir de um só semema uma estrutura morfemática de vários semas. A abstração (ou o esforço que o destinatário tem que dispender para selecionar os dados transmitidos e reter o necessário) caracteriza o funcionamento do discurso em todos os níveis (idem ibidem, p.147). A abstração é, evidentemente, um empobrecimento do conteúdo, mas é o meio através do qual garante-se a pertinência da significação transmitida.

Os sememas construídos (tal como ocorre nas linguagens documentárias) utilizam esse princípio de economia ou simplificação sêmica que simula, a seu modo, o funcionamento econômico do código (conforme proposição de Jakobson). Do mesmo modo, a condensação é um recurso para representar discursos muito abstratos e formalizados (tal como por exemplo, a Matemática), e que não necessariamente lexicalizam um número suficiente de sememas deixando-os subentendidos.

A manifestação de uma combinatória também está limitada pelas incompatibilidades decorrentes da agramaticabilidade, alexicalidade e principalmente, como ocorre no caso das linguagens documentárias, da assemanticidade (idem ibidem, p.148-149).

Além disso, os mecanismos que viabilizam a comunicação são iterativos. A sintaxe exerce, aqui, uma função essencial, porque permite operar uma nova combinatória que, a partir dos elementos dados, é potencialmente infinita (que correspondem às possibilidades de atualização, no sentido de Benveniste). Aqui encontramos, porém, um dos principais problemas das linguagens documentárias, já que o uso da lógica booleana (tal como ocorre na maior parte dos tesauros como operadores para recuperação) apresenta restrições relacionadas ao seu caráter não semântico, mas lógico. “A sintaxe semântica é, (entretanto), imanente à atividade lingüística” (GREIMAS, 1976, p.155).

A transformação do inventário de descrições em estrutura requer o uso da redução e da justaposição, que permite a estruturação propriamente dita (idem ibidem, p.208). 
A redução representa sempre um empobrecimento da significação. Na construção da combinatória documentária, porém, ela significa "o reconhecimento da equivalência entre vários sememas ou várias mensagens" e seu correspondente registro através de uma denominação comum a partir da classe de ocorrências consideradas equivalentes (idem ibidem, p.209). A decisão do nível de redução depende, neste caso, dos objetivos traçados para a representação.

A redução é realizada, geralmente, mas não exclusivamente, a partir da identificação de traços estruturais comuns através da comparação de identidades sêmicas. Neste processo, utilizase a conjunção como parâmetro, neutralizando-se a disjunção. No caso da construção das combinatórias documentárias a redução opera, genericamente, sobre elementos idênticos e parcialmente idênticos, - esta última através de deslocamentos genéricos (da parte para o todo) ou de deslocamentos colaterais (de uma parte para outra parte, por medida de economia do sistema, e em função do volume de ocorrências).

Na realidade, o procedimento descritivo revela uma busca por constantes de conteúdo realizada sempre em detrimento da especificidade de suas variáveis. Parte-se das ocorrências para transformá-las em inventários que são distribuídos em classes e subclasses, sucessivamente, até o nível desejado de especificidade, chegando a um modelo generalizável para o microuniveso semântico manifestado no corpus sob análise.

A esse gênero de descrição (ascendente), deve se seguir um outro que o completa (descendente), como meio de incorporar as variáveis abandonadas à cada etapa (idem ibidem, p.217). Com efeito, isso é caracterizado pelas recomendações relacionadas à construção de tesauros monolingües quando se sugere o uso de um procedimento misto (dedutivo e indutivo) para a formulação dos descritores e sua categorização. Segue-se ao processo de redução, o de estruturação propriamente dito, quando se utilizará uma ou várias hierarquias independentes que se encaixam para constituir a forma final da combinatória.

Devemos observar que, evidentemente, o processo de análise sugerido por Greimas foi aqui extremamente simplificado, sob pena de comprometimento de sua proposta. Ao resumi-lo pretendemos, antes, esboçar vias de pesquisa que poderão ser assumidas pela Lingüística Documentária, tornando evidentes certas similaridades identificáveis nos processos muitas vezes empíricos levados a efeito pela Documentação na formulação de suas linguagens. Esse reconhecimento é, de fato, a primeira condição para procurar assimilar o senso comum, tentar identificar seus procedimentos sistemáticos e os problemas de inconsistência visando, em última análise, reinvesti-lo de parâmetros metodológicos. 


\subsection{A comunicação documentária através de uma ótica semântico-semiótica}

Ao questionar a possibilidade de uma semântica estruturalista, Dascal acaba por sugerir uma modalidade de Lingüística semiótica, tal qual pudemos ver em Greimas. A possibilidade de integração entre as duas disciplinas está também presente em Lopes e em Eco, como meio de melhor abordar a significação.

Em seu Conceito de Texto, ao se referir ao problema do enfrentamento daquela "alguma coisa que está em lugar de outra" ou daquilo que "remete a algo que não está presente", o autor se refere a um objeto intersubjetivamente verificável que deve se tornar presente de algum modo, mesmo como caixa vazia (ECO, 1984, p.6-8). Para o autor, o 'referent' do triângulo de Ogden e Richards, deve ser entendido não como se estivesse falando de objetos, mas de "relações semióticas". Do mesmo modo, a Bedeutung, de Frege que se, aparentemente deveria ser o objeto do signo, diz respeito à satisfação de condições de verdade de uma expressão. O Sinn, seria a maneira como entendemos o signo e não sua condição de verdade. Essa reconceptualização leva Eco a propor uma reconstrução do triângulo de Ogden e Richards em termos de uma lógica contemporânea:

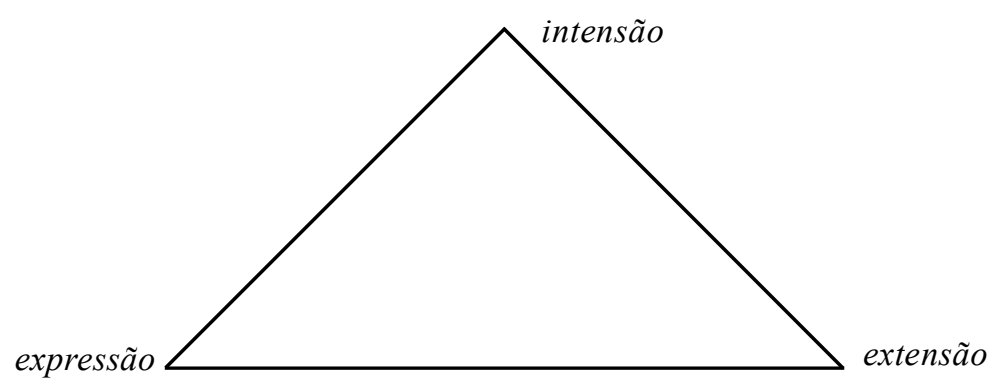

ECO, 1984. Conceito de texto. São Paulo: TA Queiroz; EDUSP, 1984, p.10.

No triângulo acima, a extensão corresponde à sua condição de verdade, ou a classe de todos os objetos a que a expressão pode ser aplicada. A intensão, a série de propriedades culturalmente atribuídas à expressão. Para Eco, quando Saussure fala de significante e significado, fala da relação entre uma expressão e suas intensões, mas poderia, também, estar falando da relação entre uma expressão e sua extensão. Isso remeteria à necessidade de distinguir dois conceitos: sistema de significação e processo de comunicação.

Num processo de comunicação, o código comum entre os interlocutores é o sistema de significação. Este, por sua vez, pode ser analisado independentemente de seu uso em processos de comunicação, através de seus planos de expressão e de conteúdo. A relação entre esses dois planos é baseada 
em postulados de significado. A partir disso, podem ser construídas expressões de extensão nula numa lógica das condições de verdade, ou de extensão x, y ou z em "mundos possíveis", ou "mundos de referência". Sistemas de significação podem ser construídos de forma que alguns possam ser comunicativamente felizes e outros não. Convenções intensionais fundam um sistema de significação. Quando estes estão em uso em processos comunicacionais, sua abordagem remete, necessariamente, à um enfoque semiótico, quando estariam presentes o código lingüístico, o modo de sua utilização e os outros componentes de uma relação triádica. Dito de outro modo, incorporamse elementos pragmáticos, ou seja, considera-se o efeito que uma expressão poderia exercer sobre o receptor ou destinatário.

A pragmática pode ser entendida como "o estudo da dependência essencial da comunicação, na linguagem natural, do falante e do ouvinte, do contexto lingüístico e extralingüístico" (BAR-HILLEL apud ECO, 1984, p.16). Porém, o limite entre o que é pragmático e o que é semântico é, muitas vezes, difícil de decidir. Relativamente a um sistema de significação, uma dada expressão pode ser sintaticamente correta e semanticamente válida, mas pode ser ambígua pragmaticamente, porque o conhecimento de fundo do intérprete (a experiência colateral) pode não ser suficiente para sua compreensão. Uma expressão pode ser falsa, em termos extensionais (semântica das condições de verdade), mas possível em termos intensionais (semântica dos postulados de significado).

Ao aproximar o modelo lingüístico e o modelo semiótico, Eco mostra como a semiótica permite falar do continuum (Hjelmslev) (ECO, 1984, p.19). O conteúdo é o continuum de que se fala e a forma de expressão é um empobrecimento do continuum da expressão. A forma de expressão é, assim, resultado de uma convenção cultural: "a função sígnica é a correlação, às vezes transitória e instável, entre uma expressão e um conteúdo” (idem ibidem, p.22-25).

O modelo hjelmsleviano (plano da expressão/plano do conteúdo) é, portanto, para Eco, mais rico e útil do que o saussuriano (significante/significado), porque permite contemplar uma teoria do conteúdo quando sugere que a língua formaliza porções do continuum (como o das cores, por exemplo), permitindo eliminar o problema da percepção que não interessa semioticamente ${ }^{20}$.(Dito de outro modo, permite estabelecer a língua enquanto objeto de estudo). Seu defeito, porém, é que o espaço de formalização do conteúdo permanece vazio e abstrato: “onde aparentemente conferimos às palavras um conteúdo, essas expressões /milimícron/, [no seu exemplo] não são conteúdo, são outras expressões de um outro sistema da expressão ...”(ECO, 1984, p.30). Para

20 Para Santaella, o pragmatismo, ou método para se determinar o significado dos conceitos intelectuais está alicerçada na metafísica ou teoria da realidade, que só pode se expressar através da mediação dos signos. Se decorrentes da semiótica, tem por finalidade determinar as categorias mais vastas, gerais e universais da experiência (SANTAELLA, 1993, p.34). Para a autora, o ponto de partida de Peirce é a natureza ôntica do percepto - aquilo que percebemos (idem ibidem, p.54). 
o autor a noção de substância do conteúdo de Hjelmslev, não é tão clara como a de substância de expressão.

Para a semiótica, não é a estrutura dos sistemas que interessa, mas a continuidade do processo semiótico. Segundo Eco, Hjelmslev negligencia o aspecto da realidade - o continuum - porque está interessado na construção de um sistema estrutural. Peirce, por sua vez, está interessado no processo da semiose como passagem contínua de signo a signo.

O objeto dinâmico seria, para Peirce, o continuum de Hjelmslev, ou "a realidade que está além das nossas construções categoriais" (idem ibidem, p.31), mas que existe para Peirce porque é aquilo que deve ser continuamente transformado pelo homem. "Construímos um representamen para falar da realidade, portanto, porque de algum modo somos motivados pela existência do objeto dinâmico" (idem ibidem). Porém, não é qualquer representamen que nos dá o objeto dinâmico, mas o que ele chama de objeto imediato. Este, é o objeto tal como nos é apresentado pelo signo, ou seja, pelo representamen. (Para Eco, é uma porção da forma do conteúdo). O objeto imediato considera apenas algumas características do objeto dinâmico. O representamen é, portanto, um objeto imediato que é apenas parte do objeto dinâmico (um “empobrecimento"). O representamen é a expressão, sempre relacionada a uma porção do conteúdo pertinentizado (que é o objeto imediato) "desprezando a indefinida riqueza do objeto dinâmico" (idem ibidem, p.32).

O problema, similar àquele encontrado em Hjelmslev, é resolver como se passa do representamen ao objeto imediato: o representamen é a expressão e o objeto imediato uma porção do conteúdo: "podemos controlar os representamina porque são físicos, e os conteúdos não, a menos que os entendamos como conteúdos mentais e imagens mentais" (idem ibidem, p.33). Relativamente aos ícones, ao representamen corresponde, como objeto imediato, uma imagem mental.

Para avançar além dessa noção, Peirce introduz uma nova categoria - o Interpretante - ou "um signo que substitui outro signo" ou para Eco, "uma expressão que substitui outra expressão" (idem ibidem, p.32). É o interpretante, assim, o responsável pelo processo de semiose ilimitada: “de interpretante a interpretante, enriquecemos cada vez mais de propriedades nosso objeto imediato" (idem ibidem, p.33), jamais saindo do objeto imediato para o objeto dinâmico. À medida que enriquecemos o objeto imediato indo de interpretante a interpretante, adquirimos um hábito, uma disposição para agir, que nos permite agir sobre o objeto dinâmico.

A partir dessa descrição do processo semiótico, Eco propõe uma definição de semântica (ou a definição de uma expressão através de elementos de forma de conteúdo expressos por outros interpretantes) atribuível à Peirce: a definição de lítio (elemento químico), para Peirce, é um exemplo de “uma definição não só das propriedades do objeto, mas dos processos que é preciso fazer 
atuar para que o objeto seja construído, isto é, para que do objeto imediato possamos passar ao objeto dinâmico" (idem ibidem, p.35).

Outra categoria introduzida por Peirce são os grounds, propriedades com as quais se analisa o objeto imediato. Para uma síntese da analogia entre as propostas de Hjelmslev e Peirce feita por Eco, compare-se:

\begin{tabular}{|l|l|}
\hline Peirce & Hjelmslev \\
\hline representamen & expressão \\
\hline objeto imediato & substância de um conteúdo atualizado por uma expressão $(\mathrm{x})$ \\
\hline ground & elementos da forma de conteúdo que caracterizam o objeto imediato \\
\hline objeto dinâmico & $\begin{array}{l}\text { continuum que manobramos para construir expressões e para falar do continuum do } \\
\text { mundo }\end{array}$ \\
\hline interpretante & nova expressão .... (x1, x2, x3 ... xn) \\
\hline
\end{tabular}

A noção de interpretante permite, para Eco, preencher o espaço vazio do conteúdo mediante interpretantes ou novas expressões, resolvendo um dos grandes problemas da semântica componencial, qual seja, o de saber que, numa análise de termos, a representação semântica feita a partir de um pacote de propriedades metalingüísticas finitas caracteriza uma descrição em forma de dicionário; ao contrário, admitindo-se que tais propriedades metalingüísticas não sejam finitas, poderemos propor uma definição em forma de enciclopédia.

A teoria peirceana permite, assim, realizar uma semiótica do conteúdo que não é nem mentalista nem platônica, pois permite afirmar que, se o conteúdo pode ser analisado através de variadas expressões que não sejam restritivas e que sejam socialmente verificáveis, "se eu afirmar que a expressão é correlata ao conteúdo, a expressão estará presente e o conteúdo ausente; mas se eu afirmar que o conteúdo pode ser analisado através de outras expressões, poderei fazer um discurso sobre o conteúdo, controlando sempre entidades fisicamente presentes que são outras tantas expressões" (ECO, 1984, p.38). Em última análise, o sentido de significado é semiótico ou perceptivo: perceber quer dizer “dar sentido, dar significado às coisas” (idem ibidem, p.39).

Analisar as representações documentárias como construtos semióticos evidencia a impossibilidade de analisá-las independentemente do processo que lhes é inerente, o que mostra, conseqüentemente, que a informação é sempre uma construção. Através do processo de comunicação documentária não se transmite informação propriamente dita, mas condições para que ela seja construída através de uma rede semiótico-semântica que configura um sistema de significação. A partir de um objeto 
dinâmico - por exemplo, um domínio - a Documentação constrói representamina (os descritores), que realizam os objetos imediatos (organização particular da porção do domínio focalizado) que tem determinado ground (traços que caracterizam o objeto imediato) permitindo estabelecer interpretantes - ou seja, construir a informação. A experiência colateral - individual-determina, por sua vez, novos interpretantes.

Analisada enquanto construto - ou representamen - uma linguagem documentária é informação, que é institucional. A partir porém, do processo semiótico-a semiose-constrói-se, individualmente, nova informação. Embora uma linguagem documentária esteja marcada pela intencionalidade - as marcas institucionais - o controle da significação não fica restrito ao âmbito das intenções comunicativas. A Lingüística permite operacionalizar as relações no interior de um sistema de significação através da identificação e seleção das oposições. Admitindo, porém, que os signos lingüísticos são, também, signos semióticos, o limite da representação documentária vai ser dado nas contribuições que possam ser oferecidas para o reconhecimento de uma estrutura de significação e para o enriquecimento da "experiência colateral” que, por sua vez, poderá sugerir interpretantes. A interpretação de uma representação documentária, portanto, não se realiza apenas em relação, quer ao código lingüístico, quer ao sub-código modelizante do domínio, por mais que se deseje impor-lhe uma direção.

A finalidade comunicacional das representações documentárias está submetida, quer se queira ou não, às possibilidades interpretativas que não podem ser sobredeterminadas a priori. A comunicação não depende da intencionalidade - como o queriam Martinet, Buyssens e Prieto porque é necessário distinguir informação da mensagem e a informação da linguagem, como bem o destaca E. Peñuela Canizal em seu prefácio aos Fundamentos da Lingüística Contemporânea, de E. Lopes. De fato, num processo semiótico concorrem, quase que simultaneamente, vários códigos: um código extradiscursivo (palavras no dicionário modelizante da língua - semiose intrasígnica invariante); um código intradiscursivo (as palavras no contexto - semiose intrassígnica processual, da mensagem); o código heterodiscursivo (a palavra enquanto signo ideológico) (LOPES, 1978, p.99). “O sentido [, pois,] nunca é uma evidência ...” (LOPES, 1987, p.233).

\subsection{Tradução intracódigo e tradução entre códigos}

Para que se estabeleça uma situação de comunicação documentária é necessário tornar explícito qual é o quadro de referência utilizado para falar do domínio, ou seja, é necessário fornecer elementos para a identificação das estruturas significantes utilizadas. Do contrário, além dos constrangimentos decorrentes desse tipo particular de comunicação, é bastante difícil que a compreensão das 'mensagens documentárias' se realize satisfatoriamente. Para a comunicação 
documentária, a competência da língua como meio para que o destinatário possa compreender a performance do remetente (sistema documentário propriamente dito) é insuficiente.

Uma situação de comunicação documentária envolve, a seu modo, uma tradução. Analisada como um código, uma linguagem documentária é um gênero de sistema modelizante secundário: utiliza a língua como base, mas constitui uma estrutura desviatória em relação a ela. Os elementos emprestados dos códigos lingüísticos são, aqui, organizados de forma peculiar, como condição prévia para representar e transmitir informação documentária. O código documentário é um instrumento destinado a realizar a transcodificação da forma de uma mensagem em outra forma (textos integrais para suas representações documentárias). É um sistema convencional que deve ser explicitamente formuladorelativamente à sua estrutura e às regras de uso - para garantir a comunicação.

Uma linguagem documentária é, também, uma espécie de metalíngua, pois constitui um tipo de 'língua tradutora' de uma língua-objeto (a dos textos, por exemplo) que modeliza os textos que pretende representar. Como nos demais sistemas modelizantes secundários, o resultado das transcodificações apresenta desvios semânticos relativamente aos seus objetos originais, desvios estes oriundos da forma de organização que utilizam. Por outro lado, ao definir um ponto de vista sobre o universo-objeto que procuram representar e, a seu modo, constituir informação, uma linguagem documentária pode ser vista, ela mesma, como Interpretante, já que sugere uma hipótese de leitura para os seus textos-objeto.

"Os signos do código capazes de traduzir os signos da mensagem constituem o interpretante da mensagem: a essa relação é que chamamos sentido. O processo de significação ... não relaciona um signo e um ‘objeto'; relaciona signos entre si”(LOPES, 1987, p.249).

É através da relação código e interpretante que E. Lopes sugere a unificação de uma proposta lingüística à proposta semiótica. $\mathrm{O}$ interpretante proveniente do código [lingüístico] funciona como operador de sentido - o que permite à língua fazer funcionar sua capacidade metalingüística. $\mathrm{O}$ interpretante, na sua concepção, "é um conceito de valor relacionante"... que permite colocar em funcionamento as funções metalingüísticas da língua.. É exatamente esse conceito que "permitenos eliminar para sempre o espectro ontológico e a falácia realista dos "referentes" extralingüísticos do âmbito da semântica (LOPES,1987, p.250-251). Para a Documentação, entretanto, não é só o interpretante proveniente do código lingüístico que funciona como operador de sentido, mas um interpretante construído a partir de um subconjunto lingüístico da língua de especialidade e a partir de sua pertinentização enquanto informação documentária.

O interpretante é um significado (metalingüístico) de significantes de uma língua-objeto, funcionando como operador semântico que executa: 
1. a tradução no interior de um código:

a) por expansão (produzindo uma definição);

b) por condensação (produzindo uma denominação);

2. a tradução entre códigos:

a) de uma língua natural para outra língua natural;

b) de uma língua natural para um código sígnico secundário;

c) de um código sígnico secundário para uma língua natural.

(LOPES, 1987, p.250-252).

Para a Documentação, a identificação dessas operações executadas pelo interpretante permite distinguir:

a) as representações documentárias realizadas sem um código intermediário comutador - os resumos, enquanto produtos obtidos por condensação;

b) as representações documentárias construídas a partir de referências terminológicas - e, portanto, realizadas a partir de subconjuntos lingüísticos das línguas de especialidade (termos e definições);

c) as representações documentárias obtidas pela mediação de uma linguagem documentária representações que caracterizam a tradução de uma língua de especialidade para um código sígnico secundário ou de um código sígnico secundário para a língua natural (as equivalências sinonímicas e quase-sinonímicas).

A noção de que a linguagem documentária pode ser vista como interpretante confirma-se quando entendemos que ela é um gênero de construção metalingüística capaz de propor uma equivalência entre dois códigos. A linguagem documentária é como um modelo que simula possuir as propriedades possuídas pelo signo ou código que interpreta (a interpretação constitui a informação, no sentido documentário).

Numa linguagem documentária, o interpretante evidencia 'isomorfia' e 'isotopia' que se estabelecem entre:

a) a língua, enquanto estrutura;

b) o sub-código lingüístico (língua de especialidade) enquanto estrutura e, principalmente, conteúdo.

A isomorfia evidencia as propriedades comuns entre as estruturas dos códigos a e b, por um lado, e o código documentário propriamente dito, por outro. A isotopia, estabelece analogias no plano interpretativo (do conteúdo).

Isomorfia e isotopia, entretanto, não significam identidade: “. . . a função cognitiva da isomorfia [e da isotopia] é a de efetuar a aproximação dos dois conjuntos (códigos, signos) através de uma operação conjuntiva, para poder propor a sua correspondência" (LOPES, 1987, p.253). 
Ao simular a estrutura da língua, as linguagens documentárias realizam a primeira operação conjuntiva. Ao simular a estrutura do domínio, realizam uma nova operação conjuntiva quanto ao plano do conteúdo, pretendendo delimitar o sub-código a partir do qual os termos devem ser interpretados. Porém, ao propor uma hipótese de organização para construir informação, as linguagens documentárias realizam uma nova operação conjuntiva em relação às duas anteriores, imprimindo o modo institucional de leitura que privilegiam (ou seja, a paráfrase informativa que pretendem instaurar).

Aceitas essas analogias, pode-se afirmar que as operações envolvidas no processo de representação documentária buscam, primordialmente, identificar operadores semânticos que possam exercer, primeiro, operações de tradução intracódigo; segundo, de tradução entre códigos.

No primeiro caso - momento em que o código documentário nasce - procura-se no sub-código que é nosso objeto (por exemplo, subcódigo de "Política Cultural", subcódigo de "População" etc.), referências para realizar seu mapeamento e para sua representação condensada - seja através do estabelecimento de redes semânticas, seja através de definições. Nesta fase, a função metalingüística caracteriza-se por operações que, por um lado, são análogas às operações de condensação utilizadas para a produção de denominações e, por outro, às operações de expansão que caracterizam a produção de uma definição. A seu modo, a estrutura relacional das linguagens documentárias deixa evidente o molde das definições quando organiza seus termos em níveis hierárquicos (Termos Genéricos, Termos Específicos etc.), tal como a figura das conjunções e disjunções. O modo como propõe o esquema de relações não é, evidentemente, o mesmo dos domínios que focalizam, mas o que privilegiam para exercer a função documentária.

No segundo caso - a partir do código pronto - pode-se realizar as operações de tradução intercódigos. Após a análise e síntese dos documentos procura-se, na linguagem documentária, os descritores pertinentes para descrevê-los sob forma condensada (o que também ocorre no processo de busca de informações).

De fato, o interpretante como operador de sentido para a compreensão de uma mensagem põe em funcionamento, como vimos, a capacidade metalingüística da língua. Além disso, "ao relacionar um operador de sentido (de modo que os signos - ou parte de signos - de uma mensagem se transcodifiquem mutuamente, no interior do mesmo enunciado), a língua põe em funcionamento a sua capacidade poética (= função poética) (idem ibidem, p.250).

Porém, ao contrário do que ocorre na língua (natural), as linguagens documentárias não dispõem de mecanismos de produtividade, o que torna suas mensagens caracterizáveis apenas como produtos metalingüísticos. Pode-se sugerir, entretanto, que o processo documentário envolve, a seu modo, 
a criação de sentido, uma vez que mobiliza um outro sistema de convenções - o documentário que evidencia que a informação é uma construção relativamente ao universo-objeto de representação.

Confirma-se, assim, que o resultado da semiose documentária (considerando-se, aqui, a construção e uso do código para a representação) é o surgimento de sentido, porém mais sobredeterminado do que na língua natural. De fato, "o sentido de um signo é outro signo que o traduz mais explicitamente", conforme interpretação de Peirce dada por Jakobson (idem ibidem). Além disso, considerando que toda significação lingüística é parafrásica (JAKOBSON), é possível supor que o processo de representação documentária é, à sua maneira, um processo dessa natureza, o que confirma, mais uma vez, o caráter metalingüístico das representações documentárias e das linguagens documentárias.

Em resumo, além de código para intermediação uma linguagem documentária constitui, enquanto totalidade, um interpretante, como também funcionam como interpretantes seus descritores. Os operadores de sentido remetem às terminologias, revelando, porém, as marcas que as caracterizam como metalinguagens que constroem, a seu modo, paráfrases informativas relativamente aos textos que pretendem representar.

\subsection{Relações lingüísticas nas linguagens documentárias}

As relações lingüísticas são identificáveis entre os significados de um significante e entre significantes eles mesmos. Não constituem, portanto, relações apenas em nível semântico, mas também entre formas.

Para falar das relações lingüísticas nas linguagens documentárias é preciso observar que as relações se dão no léxico dessas linguagens (ou entre lexemas, enquanto unidades de base do léxico, ou seja, no nível do sistema), como também no vocabulário (ou as relações que correspondem à fala). As relações lingüísticas são evidenciadas, desse modo, em dois conjuntos distintos.

No interior dos campos semânticos de uma linguagem documentária, as relações língüísticas se definem através das noções de oposição e contraste. Genericamente, uma oposição é a relação existente entre dois termos de um mesmo paradigma. Já o contraste, evidencia uma relação de ordem sintagmática. Oposição e contraste estão, pois, na mesma relação que substituição e combinação (DUBOIS et al., 1988).

O princípio da oposição binária ou dicotômica é, para Lyons, um dos mais importantes princípios que governam a estruturação das línguas (LYONS, 1977, p.220). Já os contrastes, evidenciam a 
incompatibilidade enquanto relação lexical, baseando-se, como na oposição, na similaridade (idem ibidem, p.233).

A Documentação opera mais facilmente com as oposições do que com os contrastes, já que estes últimos são empiricamente registrados em função das ocorrências na literatura ou das formulações de busca. $\mathrm{O}$ fato de as linguagens documentárias serem produto de uma construção dificulta a representação de contrastes verificados a posteriori.

\subsubsection{Campos associativos}

Para melhor compreender o que significam as oposições e contrastes é preciso afirmar, primeiramente, que a significação não pode ser abordada sem considerar o fato de que, conforme afirmou Bakhtin, no plano ideológico, a palavra é uma unidade 'neutra', apta, portanto, a se adequar a diferentes padrões culturais. Ela é portadora de uma gama de significações que a torna capaz de assumir sentidos ou valores diferentes conforme o contexto. Vista desse modo, a despeito dos semas básicos que constituem o núcleo ‘duro’ da significação da palavra, é importante verificar que ela se amolda a cada realidade contextual, significando conforme as focalizações privilegiadas. É discutível, inclusive, se as palavras têm uma primeira significação. De fato, ela não é fixa, pois é uma característica intrínseca da palavra significar de maneira própria a cada ocorrência (CINTRA et al., 1994, p.53-54).

Do ponto de vista paradigmático "todo e qualquer elemento da langue se deixa colocar no interior de uma classe onde se associa a outros membros formando um sistema" (relações associativas), permitindo memorizar elementos que possuem uma mesma marca semântica em sua base, enquanto elementos de uma classe (LOPES, 1987, p.235). Do ponto de vista sintagmático, os elementos da língua tem seu significado discernível pelo contraste entre os elementos presentes na parole (idem ibidem), o que também pode ocorrer entre unidades do vocabulário.

Para a semântica estrutural, a descrição de uma palavra pode ser feita a partir das relações que a situam como palavra-tipo, nas classes e, ao mesmo tempo, como palavra- evento, nos enunciados da parole. A análise semântica estrutural mostra, também, que é possível prever combinações de palavras em diferentes contextos-ocorrência (abertura semântica ou valência), desde que os termos possuam um traço semântico comum. Esse mecanismo de combinações institui a interdependência sintagmática ou pressuposição, noção que explica a rede de relacionamentos entre os descritores e inclui, além das relações verticais, as horizontais.

A partir da semântica estrutural as definições analíticas propostas pela Lógica passam a ser semânticas, utilizando proposições mínimas baseadas na diferença, ao modo da definição aristotélica. 
Foi a noção de interdependência semântica que permitiu a Hjelmslev mostrar a possibilidade de formalizar uma teoria e uma técnica de descrição do plano de conteúdo das línguas (formalização à qual já nos referimos anteriormente). A possibilidade de construir um inventário da língua partia da noção de que seria possível localizar unidades menores que o signo (figurae, hoje semas) a partir das quais seria possível estabelecer uma análise do sentido.

Genericamente, a construção do sentido nas línguas naturais pode ser analisada a partir da estruturação de campos semânticos ou campos associativos. A hipótese de que os sentidos poderiam ser organizados lingüisticamente abarcando todo o campo da realidade levou, depois, Trier à formulação da teoria dos campos semânticos que, a despeito dos problemas mais tarde identificados quanto à possibilidade de organizar todo o universo lingüístico (segundo Lopes essa proposta tem o inconveniente de pressupor compartimentações estanques nas línguas), teve a vantagem de permitir identificar que é possível formalizar campos associativos enquanto subsistemas que incluem novos subsistemas.

A noção de campo associativo (que hoje substitui a de campo semântico muito identificada com a proposta de Trier) é utilizada na construção de linguagens documentárias a partir da delimitação de um universo-objeto, enquanto sub-código dentro do código que é a língua. A diferença entre as associações nas línguas naturais e as associações nas linguagens documentárias, é que, na primeira, elas são virtuais; nas segundas, são construídas. Se na descrição das línguas pode-se utilizar a semântica componencial - análise através dos traços que compõem as palavras, num processo de decomposição semântica - na Documentação utilizam-se atributos para aproximar os conceitos. No plano de organização dos descritores, a classificação é relativa, baseada nos atributos que são considerados pragmaticamente importantes para representar documentariamente o domínio. Os atributos não pertencem aos conceitos. Ao contrário, são facetas construídas para a análise, que têm como objetivo permitir aproximações entre conceitos.

Ao operar com a noção de campo associativo as linguagens documentárias tornam explícita a rede semântico-pragmática utilizada para a organização dos termos, ou seja, concretizam a configuração das relações utilizadas a partir da hipótese de organização.

Se o processo de associações mnemônicas que permite estruturar os campos associativos, nas línguas naturais, é aleatório, nas linguagens documentárias é realizado a partir de mecanismos que permitam estabelecer quais parciais semânticos devem ser tratados como "iguais". Um paradigma semântico é formado por elementos que pertencem a mesma classe de sentido, e como as relações conjuntivas que permitem correlacionar os elementos em nossa memória da língua provém de um mecanismo aberto e dinâmico, trata-se, aqui, de dirigir a associação, selecionando os elementos tomados como pertinentes para contemplar um determinado domínio. 


\subsubsection{Polissemia, homonímia, monossemia, homossemia}

Na construção de uma linguagem documentária, a constituição de uma classe não elimina a polissemia, mas orientaa organização dos elementos a serem arranjados em campos semânticos conformenecessidades funcionais. Nãoeliminara polissemia significa, nestecaso, a possibilidade de apresentar tantas organizações em campos semânticos quantas forem necessárias para dar conta da diversidade dos modos de compreender o significado dos elementos em pauta,já que apenas a determinação do domínio-particularmente nas áreas emergentes - não é condição suficiente para afirmar que ela possa ser eliminada.

Oenfoque do problema da polissemia permite compreender que os termos deuma linguagem documentária podem assumir diferentes valores conforme as relações estruturais que os afetem, permitindo propor tantas associações quantas forem necessárias para dar conta dos aspectos considerados relativos ao domínioobjeto.

Nas linguagens documentárias a palavra é focalizada tendo como referência um domínio do saber ou uma área de atividade, o que determina a construção de seu significado. Essa construção pressupõe a existência de mecanismos interpretativos próprios que visam o funcionamento das unidades documentárias como unidades de informação. Diferentemente do que ocorre na língua onde a palavra é sempre fonte de significação-em função da possibilidade de plurissignificação e em razão da natureza polissêmica da palavra-nas linguagens documentárias procura-se direcionar a interpretação reduzindo-sea ambigüidade.

A constituição de uma linguagem documentária parte do vocabulário de áreas especializadas ou das atividades, e não do léxico da língua. Em grande parte, é elaborada a partir do corpus de um domínio, através da identificação de suas palavras-tipo e palavras-ocorrência. A polissemia, fenômeno da área vocabular, que normalmente pode ocorrer ao nível do léxico, não necessariamente ocorre no nível do vocabulário graças àcontextualização. Umavezque as linguagens documentárias operam sobre vocabulários e não sobre o léxico da língua, pode-se pressupor que a polissemia não sejaum fenômeno a ser considerado para sua construção. Isso, entretanto, não é inteiramente verdadeiro.

Entende-se por polissemia a propriedade do signo lingüístico de possuir vários sentidos. A polissemiaé normalmente observada em oposição à monossemia ou em oposição à homonímia. Em oposição à monossemia, observa-se queum termo, unidade de um vocabulário científico ou técnico, pode serconstituído por empréstimo de uma palavra do vocabulário geral. No primeiro, o termo é considerado monossêmico (tal como Ferro, no vocabulário da química, substituível pelo símbolo Fe). No segundo, ferro é uma unidade polissêmica, pois comporta vários sentidos: ferro $=$ metal; ferro $=$ objeto(indeterminado) de ferro; ferro = objeto determinado de ferro, etc (DUBOIS et al., 1988, p.471). Já em relação à homonímia observa-se que, para a descrição dos significados, delimitam-se "fronteiras entre unidades suscetíveis de uma descrição por vários micro-sentidos, e unidades que necessitam de descrições diferentes" (idem 
ibidem, p.472). Para Sager, os termos criados por iniciativa polissêmica devem ser considerados como homônimos (SAGER et al. apud BÉJOINT, 1989, p.230), o queé mais fácil se os termos são utilizarmos em domínios distintos (BÉJOINT, 1989, p.408)

De fato, há vários critérios para distinguir entre polissemia e homonímia, porém não conclusivos: critérios que procuram estabelecer correlações entre polissemia/homonímia e cultura/freqüência; critérios sobre rendimento proporcionado por um tratamento e outro no dicionário, critérios etimológicos, critérios de desambigüização a partir de micro-sentidos verificáveis pela diferença na ordem de palavras etc. A gramática gerativa propõe distinguir, também, os homônimos sintáticos, que evidenciam que à frases analisadas na sua estrutura de superficie, podem corresponder duas estruturas profundas diferentes. Neste caso, teríamos a ambigüidade (como por exemplo: 'Omagistradojulga as crianças culpadas'). A ambigüidade, por sua vez, pode ser do léxico, quando certos morfemas têm vários sentidos ('Ele estava em minha companhia') (DUBOIS et al., 1988).

A abordagem semasiológica ${ }^{21}$ de Barbosa mostra que, na polissemia propriamente dita, a um elemento do conjunto significante correspondem dois ou mais do conjunto significado, estes em relação de oposição transitiva, enquanto na monossemia, a um elemento do conjunto significante corresponde um elemento e só um do conjunto significado. Na homonímia, a um elemento do conjunto significante correspondem dois ou mais elementos do conjunto significado, estes em relação de oposição disjuntiva(BARBOSA, sd., p.1). O gráfico abaixo permite visualizar a questão:
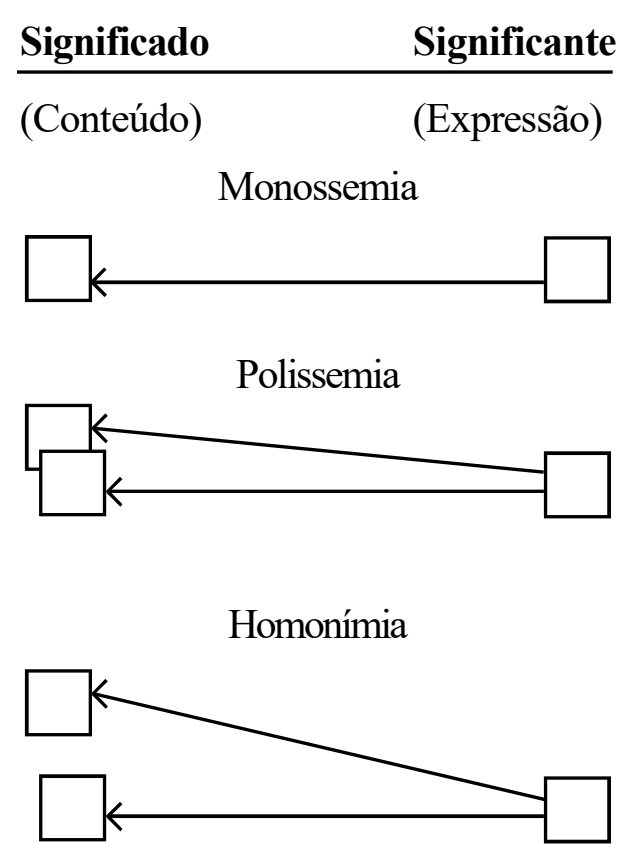

(BARBOSA, s.d., p.1)

21 A abordagem semasiológica vai do significante para o significado. A abordagem onomasiológica, do significado para o significante. 
A distinção entre homonímia e polissemia é, para Lyons, "indeterminada e arbitrária", dependendo do “juízo do lexicógrafo sobre a plausibilidade da 'extensão' do significado, ou de alguma prova histórica de ter ocorrido particular extensão. A arbitrariedade da distinção ... se reflete nas discrepâncias de classificação entre diferentes dicionários..."(LYONS, 1979, p. 431).

No âmbito da Terminologia, a rigor não se poderia falar em monossemia strito sensu particularmente na Terminologia onomasiológica - porque esta admite que dentro de um domínio o sentido é forçosamente único ou unívoco. A univocidade seria, então, a monossemia ao inverso, quando a um sentido corresponderia uma forma ${ }^{22}$, ou mais precisamente (já que a fórmula poderia corresponder à ausência de sinônimos), a um sentido corresponderia uma só forma (BÉJOINT, 1989, p. 408-409). A preocupação da Terminologia onomasiológica é evitar a ambigüidade. Se a Terminologia adota o ponto de vista onomasiológico, ela não trabalharia sobre o signo, já que não se pode pensar o significado de uma forma abstrata (ou seja, não se pode pensar sem signos) (BÉJOINT, 1989, p.407).

A Documentação procura, em geral, conter a polissemia visando assegurar uma interpretação monossêmica (ou melhor, unívoca), já que "a informação, ao contrário da significação geral, deve ser determinada. Para que ela o seja, a significação que a representa não pode ser de natureza polissêmica" (CINTRA et al., p.57). Entretanto, em domínios em formação ou transformação, é preciso assimilar o caráter polissêmico do vocabulário procurando descrever, sempre que possível, as várias nuances de significados decorrentes de teorias (ou modos de abordagem) distintas. Além disso, uma vez que a informação é sempre uma construção, pode-se indicar como ela deve ser interpretada, porém nunca definitivamente. É mais pertinente afirmar, portanto, que a polissemia seja observada como variação, e como tal integrada às linguagens documentárias.

É necessário distinguir, entretanto, entre polissemia e plurissignificação. A polissemia é uma propriedade da língua; já a plurissignificação, um fenômeno do discurso. No domínio das Documentação seria mais pertinente falar em polissemia. Nas linguagens documentárias, a partir da referência de uma Terminologia clássica - a um conceito corresponde uma única forma - não teríamos, a rigor, a polissemia, mas a homonímia, uma vez que os termos seriam definidos pelos domínios. Os termos seriam homônimos (e monossêmicos) e sua interpretação remeteria aos domínios particulares. (É por isso que grande parte da literatura documentária sobre a construção de linguagens documentárias só trata da homonímia). Entretanto, considerando uma Terminologia que combina procedimentos semasiológicos aos onomasiológicos, ou mesmo a Socioterminologia, que tende a privilegiar o uso dos termos, poderíamos falar da polissemia, já que se considera a dinamicidade dos discursos e a possibilidade de ocorrência de usos diferentes (embora, às vezes,

$22 \mathrm{Na}$ abordagem semasilógica - uma forma para um sentido - a flecha não é bidirecional. A fórmula não é reversível porque a um sentido, uma forma, corresponderia à ausência de sinônimos (BÉJOINT, 1989, p.407). 
próximos) da mesma expressão para falar de conceitos diferentes. Só uma Terminologia que aceite a polissemia permitiria dar conta das variedades de uso dos termos nas áreas em formação e transformação.

\subsubsection{Antonímia e Sinonímia}

No vocabulário, a antonímia é, talvez, a manifestação mais evidente da oposição binária. Muito embora o termo antônimo seja, normalmente, tratado como o oposto de sinônimo, é importante salientar que, conforme sugere Lyons, ao compararmos e contrastarmos dois objetos quanto ao fato de possuírem ou não determinadas propriedades, fazemo-lo principalmente com base na semelhança: "as oposições são estabelecidas sobre uma dimensão de similaridade" (LYONS, 1977). E, desse modo, há que se considerar a possibilidade de existirem vários graus de oposição. No estudo da língua, embora a antonímia seja a manifestação mais evidente dessa oposição, também a sinonímia, a hiponímia, a polissemia, a homonímia devem ser observadas como seu resultado. Do mesmo modo, a observação da ambigüidade.

As linguagens documentárias não são mais do que a explicitação de um determinado campo associativo cujo ponto de partida é definido - contrariamente ao que ocorre nas línguas naturais -, e cujo desenvolvimento tem um caráter preditivo, construída que é a partir de unidades preferenciais que funcionam como palavras-tipo e, em certa medida, como palavras-ocorrência. O ponto de partida para o estabelecimento dos subcampos associativos desse domínio são as categorias selecionadas para organizar, documentariamente, os subcampos do domínio-objeto e assim sucessivamente.

Entre sinônimos e os antônimos existe isomorfia, ou seja, analogias instauradas pela existência de um sema comum (ou um "núcleo duro" de significação comum) entre os dois termos analisados. No caso dos sinônimos existe uma relação de equivalência entre dois termos x e y que, sob certas circunstâncias, podem ser intercambiáveis. A concepção da língua enquanto estrutura, por um lado, mais o entendimento de que existe correspondência de sentido entre duas palavras (ou dois termos), por outro, evidencia a não existência de sinônimos perfeitos. Embora eles compartilhem do mesmo núcleo básico de significação, sua definição, enquanto positiva e simultaneamente negativa (a língua enquanto sistema de valores) implica sua não-identidade. A sinonímia, embora seja um fenômeno identificável na área vocabular, não é uma propriedade da palavra, mas da língua. A determinação do sentido de uma palavra só é possível a partir do contexto. Se a determinação do sentido é, nessa medida, uma operação arbitrária, que varia de contexto a contexto, na Documentação procura-se delimitá-lo interpretando os termos em função dos domínios a partir dos quais são observados. 
Os sinônimos nas linguagens documentárias permitem estabelecer as relações de equivalência entre termos preferidos e não-preferidos, funcionando como meio de controle da variação de significado e como recurso para o acesso à linguagem do sistema.

Para resolver a controvérsia sobre a existência ou não de sinônimos perfeitos os lingüistas sugerem a utilização do termo "quase-sinônimo". Na Documentação utiliza-se "sinônimo" para os termos de uma língua que designam a mesma noção e que, em certas circunstâncias são intercambiáveis, reservando-se "quase-sinônimo" para contemplar as formas que não são intercambiáveis. Admitindo, entretanto, a não existência de sinonímia perfeita, fica difícil afirmar quando os termos são ou não intercambiáveis.

\subsubsection{Hiponímia}

Como já afirmamos, é no eixo paradigmático das linguagens documentárias que é mais simples trabalhar com as noções de oposição. A categorização representa, assim, o recurso para iniciar o processo de reunião dos elementos da linguagem a ser construída. As categorias constituem o modo operacional de determinação do arranjo das significações.

Normalmente abordada do ponto de vista da organização lógica, a hiponímia é um fenômeno que dá conta da organização hierárquica dos vocabulários. Operando principalmente com a noção de inclusão, é através do tratamento da hiponímia que se consegue, nas linguagens documentárias, compensar alguns aspectos derivados da ausência de sua capacidade de sintagmatização. Ao registrarmos, de forma sistemática, a organização dos vocabulários a partir da noção de classe, tornamos presentes as relações associativas normalmente utilizadas pelo falante a partir da memória da língua. Com efeito, o registro dessas associações nas hierarquias não se caracteriza sempre como inclusão estrita, mas admite a composição de séries baseadas na noção de funcionalidade e de uso efetivo.

Na realidade, o uso da noção de hiponímia (e a heteronímia ou superordenação) nas linguagens documentárias deve ser entendida de maneira abrangente. De fato, é a dimensão hierárquica própria à organização dos vocabulários que interessa à construção das linguagens documentárias, porém a concepção de hierarquia não pode ser abordada como envolvendo, necessariamente, herança de propriedades. A hierarquia é uma ferramenta para a estruturação, sendo, desse modo, um recurso para a apresentação dos descritores. Sob uma hierarquia são apresentados os termos que se caracterizam por inclusão lógica e semântica, porém, também, relações onde não há subordinação de fato. Esse é o caso das relações todo/parte, das relaçõesoriundas das relações mnemônicas entre elementos da mesma classe paradigmática e daquelas resultantes das associações estabelecidas pelo uso na enunciação. 


\subsection{A sintagmatização e as relações estabelecidas pela enunciação}

Como já afirmamos, é no campo das relações paradigmáticas que uma proposta de Lingüística Documentária encontra maior possibilidade de desenvolvimento. As linguagens documentárias são extremamente precárias quando analisadas sob o ponto de vista da sintagmatização, em razão da ausência da produtividade cararacterística dos sistemas sígnicos secundários que carecem da dupla articulação.

A ausência da possibilidade de sintagmatização, tal como ocorre nas línguas naturais, explica uma das principais dificuldades enfrentadas pelos usuários para "compreender" uma linguagem documentária e utilizá-la de modo satisfatório. Para compensar (pelo menos em parte) a ausência dessa capacidade, a construção das linguagens documentárias procura tornar presentes as oposições instauradas entre membros da mesma classe - palavras-tipo -, registrando, ao seu lado, relações associativas, muitas das quais identificadas nos próprios discursos que constituem seu objeto-palavras-ocorrência.

O registro desse gênero de relações que não constituem relações do léxico, mas do discurso (as associações são válidas apenas no interior do domínio), permite integrar, a seu modo, a interdependência sintagmática (ou pressuposição) no interior do vocabulário das linguagens documentárias.

Através desse recurso, constrói-se uma hipótese de interpretante que agrega, ao conjunto de relações estruturais propriamente ditas, exemplos freqüentes de associações normalmente instauradas nos discursos do domínio focalizado. Além de funcionar como meio de confirmação de um campo semântico estabelecido pelas relações de hiponímia (ou ainda, seu contexto de ocorrência), esse mecanismo procura compensar a falta de capacidade de sintagmatização das linguagens construídas.

De fato, nas linguagens documentárias, os Termos Relacionados pragmaticamente ou por contigüidade espaço-temporal (e que, portanto, não podem subsumar-se à hierarquia) gravitam em torno dos termos organizados hierarquicamente, integrando, a seu modo, as unidades que se relacionam por interdependência sintagmática ou pressuposição. Os Termos Relacionados não se organizam no eixo paradigmático das linguagens documentárias, pois constituem relações na maior parte das vezes resultantes da enunciação. Correspondem, grosso modo, às relações que, no seu sentido estrito, são decorrentes do fenômeno de 'abertura semântica' (LOPES, 1987, p. 237), evidenciando informações contidas de forma imanente num enunciado, porém fora da mensagem propriamente dita.

Os Termos Relacionados evidenciam, verdadeiramente, relações ditas pragmáticas. É por isso que tesauros que têm universos que se interseccionam em alguns pontos não apontam, 
necessariamente, para o mesmo conjunto de Termos Relacionados: eles tornam explícitas relações que ocorrem nos domínios nucleares considerados, embora não digam respeito diretamente ao núcleo duro de significação.

A despeito da ausência generalizada de sintagmatização nas linguagens documentárias, pode-se verificar tentativas de criar mecanismos para que ela se efetive. Sob este aspecto lembre-se do SYNTOL citado anteriormente, que permite evidenciar, simultaneamente, relações propriamente lingüísticas e relações de enunciação. 


\section{OPERADORES DE SENTIDO PARA AS LINGUAGENS DE REPRESENTAÇÃO DOCUMENTÁRIA: A CONTRIBUIÇÃO DA TERMINOLOGIA}

Para se constituir num instrumento de comunicação a linguagem documentária deve prever a possibilidade de:
a) funcionar como código inteligível;
b) caracterizar-se como metalinguagem;
c) funcionar como fonte para interpretação de sentido;
d) incorporar o usuário como integrante do processo.

Nem sempre, porém, essas características estão presentes, já que o processo de sua construção nem sempre é realizado de forma rigorosa. Nas linguagens documentárias os operadores de sentido para interpretação são constituídos de forma complexa, pois têm sua origem na articulação de distintos códigos: o código da língua, o subcódigo relativo ao domínio-objeto e o subcódigo da Documentação. Analisadas como interpretantes, têm nos subcódigos do domínio-objeto as referências principais para a construção do sentido, assumindo características de um modelo que simula possuir as propriedades possuídas por aquele código que interpreta (a organização dos conceitos na língua de especialidade). Passam, desse modo, a funcionar como metalinguagem, evidenciando, através da isomorfia, suas propriedades comuns.

O recurso à terminologia dos domínios é, para as linguagens documentárias, fundamental, uma vez que permite identificar o subconjunto lingüístico a partir do qual as palavras passam a significar. Vale lembrar que, ao proceder o isolamento das palavras de seu contexto (textos originais), as linguagens documentárias enfrentam o problema da perda da significação contextual. Referindose, por sua vez à terminologia dos domínios, recuperam as condições de interpretação generalizáveis para o conjunto dos textos daquela especialidade.

Para buscar referência na Terminologia, é necessário, antes, procurar entendê-la na sua constituição. É o que faremos a seguir.

\subsection{A Terminologia: princípios e normas terminológicas ${ }^{23}$}

“A Terminologia é um campo interdisciplinar e transdisciplinar e envolve não só a descrição e o

23 Neste trabalho referimo-nos às propostas de tradução das normas ISO 704 e ISO 1087 para o português ainda não submetidas à votação até a presente data (1999). 
ordenamento do conhecimento (nível cognitivo), mas também a transferência de conhecimento (nível comunicacional). Seus elementos centrais são conceitos e termos" (ISO 704, proposta de versão brasileira).

Para a norma ISO 1087, “Terminologia” é o “estudo científico dos conceitos e dos seus respectivos termos considerados em seu funcionamento social e pertencentes a áreas da experiência humana". Enquanto objeto concreto, as terminologias são um "conjunto de termos que representam um sistema de conceitos de um domínio particular”(ISO 1087, proposta de versão brasileira).

Admite-se, nas duas definições acima, o caráter mediador dos termos e conceitos, mediação essa que se dá a nível cognitivo e a nível comunicacional. "Entre objetos, de um lado, e os signos lingüísticos, de outro, não há relação direta. A relação é feita via conceitos" (ISO 704). Ora, os conceitos são construções e, como tal, refletem modos de organização privilegiados. O modo como as normas se referem à mediação revela seus pontos de partida para a análise das representações.

Segundo a norma ISO 704, "a realidade se manifesta no ser humano como objetos que são reconhecidos por um "certo número de propriedades". "Propriedades comuns a outros objetos da mesma classe reúnem-se em nódulos mentais ou esquemas cognitivos chamados conceitos" (norma ISO 704). Para a norma ISO 1087, o "objeto" constitui "o elemento passível de ser percebido e que pode ser representado por um termo ou símbolo". Os termos reconhecer e perceber encaminham a análise à 'descoberta', supondo a realidade como um dado passível de ser descrita como tal.

Para Le Guern, as propriedades, por si só, não são suficientes para a descrição dos objetos, a menos que estejam contextualizadas em universos determinados. As propriedades são apenas traços distintivos que permitem distinguir as palavras no interior da língua. A determinação da 'classe de objetos' remete a paradigmas, ou seja, realiza-se em referência a universos específicos (LE GUERN, 1990). Para designar objetos da realidade extra-lingüística (e desempenhar sua função referencial) as línguas têm "o poder de construir o universo ao qual elas se referem" (DUCROT \& TODOROV, 1988, p.229).

Na proposta da versão brasileira da norma ISO 704 afirma-se que "as características são as propriedades dos objetos e, ao mesmo tempo, suas representações mentais que se combinam para formar o conceito"; já segundo a norma ISO 1087, a característica é uma "representação mental de uma propriedade do objeto e que serve para delimitar seu conceito" (ISO 1087). Em ambos os casos verifica-se que as normas tendem a conferir, às representações, um caráter eminentemente extensional, o que poderia pressupor uma intrínseca ligação entre as palavras e as coisas. Porém, se por um lado, a ênfase no objeto extralingüístico poderia aproximar tais normas 
de uma concepção estritamente extensional característica da Teoria da Referência (para a qual o significado de um termo é dado pela classe de objetos a que ele pertence), por outro, o caráter mediador do conceito remete ao paradigma saussuriano (não há relação direta entre objetos e signos lingüísticos).

De qualquer modo, a norma ISO 704, na proposta de versão brasileira, tende a apresentar uma visão mais mentalista. Confirma-se o que estamos dizendo quando se pressupõe a existência de um momento em que o conceito é uma unidade puramente mental. Vejamos: "O conceito, enquanto entidade puramente mental, contém as características num amálgama, numa síntese mental. As características estão implicadas naquele átimo de tempo durante o qual "compreendemos" o que seja um objeto. Quando se reflete sobre o conteúdo dessa síntese (a que se chama comumente 'conceito'), vê-se que tal conteúdo amalgamado, indistinto, passa a ser explicitado nas chamadas 'características'. As características até então implicadas na síntese mental passam mediante a reflexão a ser explicadas num processo analítico do pensamento. Até esse ponto, o conceito permanece impossível de ser comunicado, não só porque a implicação (a síntese) é puramente mental, como porque as características são demasiadamente extensas e numerosas para serem confortavelmente usadas na comunicação. É necessário, por isso, uma outra entidade suficientemente ágil para ser manipulada e que seja novamente a implicação (a síntese) das características" (norma ISO 704, item 9.1.1 $)^{24}$.

Ora, a definição do signo lingüístico proposta por Saussure não pressupõe a existência de um nível conceptual autônomo e preexistente ao nível lingüístico. Do mesmo modo, para Hjelmslev, a linguagem deve ser vista como uma realidade em si, na sua própria imanência, sem o caráter de meio para inúmeros fins. A versão brasileira da norma parece admitir a existência de uma estrutura de pensamento independente da "enformação" (DUCROT \& TODOROV, 1988, p.26) lingüística. Para Saussure, se cada língua, "a cada momento de sua existência, apresenta uma certa forma e organização, não se trata certamente do efeito de uma função preexistente à sua função de comunicação, pois a organização inerente a cada língua é o sistema. O conhecimento dos elementos lingüísticos não é dado e ninguém poderia ler diretamente na experiência quais são os elementos postos em jogo na língua" (idem ibidem, p.27).

Já na norma ISO 1087 a ênfase no aspecto extralingüístico é realizada no contexto da relação língua/realidade. Dessa forma, os pontos de referência para a caracterização do objeto são as áreas, domínios e subdomínios, e a língua de especialidade é o subsistema lingüístico através do qual se dá essa relação. Quando se enfatiza a relação língua/realidade e se remete a decupagem

24 Esta afirmação consta na proposta de versão brasileira, ainda não definitiva. 
do objeto às línguas de especialidade (e não à língua comum), são os subsistemas correspondentes a essas línguas de especialidade que vão realizar (e justificar) os recortes na realidade. No caso geral das línguas de especialidade, as expressões situam-se em contextos particulares (domínios) e "referem-se" a objetos particulares do mundo real ("tudo a que se faça referência deve existir" (SEARLE, 1969, apud LYONS, 1977, p.172). Não se trata, nas línguas de especialidade, de saber o que as palavras e as expressões significam na língua, mas o que elas são, naquele contexto particular. Enquanto subconjunto do sistema lingüístico, as línguas de especialidade refletem um modo mais ou menos normalizado de se comunicar num dado domínio do saber, o que seria impossível na língua geral.

De fato, a maneira como a língua de especialidade recorta a realidade depende, antes, da forma de organização privilegiada pelo domínio. São os 'valores' do domínio (escolhas, paradigmas) que irão determinar as hierarquias e relações dentro do subconjunto do sistema lingüístico "língua de especialidade". Essa manifestação de valor é característica não de uma teoria extensional, mas, ao contrário, de uma teoria intensional (originada com Saussure e base de uma semântica estrutural) que tem como núcleo central a questão do lugar que os elementos ocupam dentro do sistema. Aqui, o significado não tem existência antes do sistema e os valores são dados pela diferença. Por outro lado, a natureza comunicacional do signo lingüístico revela a manifestação de uma intencionalidade, e portanto, de seleção e escolha. É fundamental, portanto, essa ancoragem nas línguas de especialidade apontada pela norma ISO 1087.

Embora sem ênfase similar, na norma ISO 704 também se reporta à língua de especialidade, como podemos ver a seguir:

"Nas línguas especiais (Ciência e Tecnologia, por exemplo), formas lexicais escolhidas para a representação de conceitos precisam ter propriedades estritamente delimitativas (...) A definição é constituída das características relevantes a uma específica área de conhecimento (...) Uma terminologia normalizada geralmente revela a presença de uma língua especial ou de um subconjunto dela ..." (norma ISO 704).

A partir do exposto, pode-se supor que a atual proposta de versão brasileira da norma ISO 704 oscila entre o paradigma saussuriano (intensional) e o da Teoria da Referência (extensional). Em que pese tal fato, deve-se salientar que, dado o caráter pragmático da Terminologia, a referência aos procedimentos de uma teoria extensional pode não significar a adoção de uma Teoria da Referência strito sensu. Ela se deve à busca de operacionalidade para a delimitação do objeto. A Terminologia, para exercer sua função comunicativa, tem procurado procedimentos que possam dar conta de uma dimensão cognitiva do mundo real, tratando os conceitos como elementos do conhecimento. Assim sendo, busca na Teoria da Referência os procedimentos para relacionar as 
estruturas de conhecimento à linguagem e definir seus elementos constituintes.

Segundo a interpretação de Sager, a Teoria da Referência fornece princípios para a classificação de "itens de linguagem, não à base de suas propriedades formais... mas de acordo com as propriedades aos quais se referem" (SAGER, 1990, p. 14). Sager faz uma referência à norma original ISO 704, segundo a qual “a questão da referência é abordada, primeiramente, pela proposição de um modelo do conhecimento que nos permita descrever, relacionar e classificar conceitos" (idem ibidem). Tal modelo do conhecimento precisa ser concernente "ao conhecimento designado pelos itens lexicais: precisa não mais do que formalizar alguns princípios de organização conceptual implícitos na análise componencial, teoria dos campos semânticos e taxionomia lexical. Esse modelo é concebido como um espaço multidimensional no qual eixos que se interceptam representam algum tipo de primitivos conceptuais ou características" (idem ibidem).

A maneira como se assimila a Teoria da Referência remete a valores: "um conceito, isto é, uma unidade do conhecimento, pode ser representada e identificada unicamente pelas referências às suas coordenadas ao longo de cada eixo" (idem ibidem). A referência, para Sager, desempenha a função de mapear, de um repertório enumerável de símbolos, o léxico, no espaço contínuo do conhecimento. A referência de cada item lexical tem, como sua imagem, uma região do espaço do conhecimento cujos limites podem variar entre indivíduos, embora a extensão de variação deva-se ao maior ou menor grau de restrição imposta pela norma social. Como resultado, "qualquer estrutura interna existente é transferida automaticamente ao léxico, mas somente em virtude do relacionamento que une cada entrada lexical discreta e a totalidade de pontos que constitui a região correspondente de conhecimento"(SAGER, 1990, p.17). Sem entrar na discussão sobre "primitivos conceptuais" - o que questionamos - , a interpretação de Sager relativiza a questão extensional.

Além das definições de Terminologia veiculadas no âmbito das normas internacionais, pode-se destacar outras encontradas na literatura que poderão (deverão) nortear o nosso trabalho.

Adefinição de Dubuc enfatiza que a Terminologia está voltada essencialmente às funções de expressão e comunicação, destacando as necessidades do usuário como "norteadoras" do desenvolvimento de terminologias específicas. Segundo Dubuc, "a terminologia é a arte de identificar, analisar, com o objetivo de criar o vocabulário para uma técnica dada, numa situação concreta de funcionamento, de maneira a responder aos objetivos de expressão do usuário" (DUBUC, 1977, p.6). A função da Terminologia, nesse sentido, mostra que a língua, em si, é insuficiente para garantir uma comunicação unívoca. A definição de Dubuc, entretanto, não aborda a questão do conceito e seu objeto.

Já a definição de Desmet contempla as terminologias enquanto objetos concretos. Segundo Desmet, “As terminologias, enquanto conjunto de termos de um dado domínio, são vistas como verdadeiros 
sistemas definicionais; os termos, como sistemas organizados que refletem uma organização conceptual; a definição, como o único meio de estruturação das terminologias"(DESMET, 1990, p.5).

Sua concepção de Terminologia enquanto área de trabalho pode ser inferida a partir de suas afirmações relativas à definição terminológica (de que trataremos mais à frente), como semelhante à apresentada pela norma ISO 1087. A autora torna mais precisa a noção de que somente uma semântica relacional pode fundamentar a Terminologia.

A forma lingüística 'terminologia', para Rondeau, pode recobrir várias noções. Para uma dada noção, as definições são múltiplas e diferentes, mais ou menos segundo a ótica a partir da qual se coloca o autor: conjunto de termos de um domínio; métodos de coleta e classificação de termos, criação neológica, normalização e difusão; ciência cujo objeto é de ordem lingüística, mas que é essencialmente pluridisciplinar e que recorre às vezes à lingüística, às vezes à lógica, à ontologia, à classologia e à informática (RONDEAU, 1984, p. 18).

Vê-se que a Terminologia tem vertentes que a aproximam ou da lógica ou da lingüística. A origem da Terminologia enquanto ciência surge com Wüster (1930), cuja proposta é identificada como a Escola de Viena. Segundo Slodzian, a Teoria Geral da Terminologia de Viena - VGTT, revela traços de uma herança neo-positivista - devidas ao Wittgenstein do Tractatus LogicoPhilosophicus - , traços esses que se encontram também na Teoria Geral dos Termos - GTT, mais recente (década de 70), ligada à INFOTERM, em seu objetivo de controlar, harmonizar em nível mundial os fluxos terminológicos. O quadro ideológico no qual foi construída a GTT - o universalismo dos anos 30 - , privilegia naturalmente o objetivo prescritivo em relação ao descritivo coincidindo, no plano epistemológico, com as características principais da "Concepção Científica do Mundo", Manifesto do Círculo de Viena: empirismo e positivismo, conhecimento decorrente da experiência, análise lógica, objetivo de uma ciência unitária, redução do conceito a outros conceitos etc. (SLODZIAN, 1995, p.11-13).

\subsection{O termo}

O termo é a unidade mínima da terminologia. Segundo a norma ISO 1087, o termo éa "designação de um conceito por meio de uma unidade lingüística definida numa língua de especialidade". (A designação é qualquer representação de um conceito). A norma ISO 704 define um termo como "uma designação que consiste em uma ou mais formas lexicais, atribuída a um conceito definido numa língua especial".

Para Rondeau, “o termo é essencialmente um signo lingüístico no sentido definido por F. de Saussure (1916), ou seja, uma unidade lingüística que comporta um significante e um significado"(RONDEAU, 
1984, p.19): o significante corresponde à denominação e o significado, à noção (idem ibidem). O que distingue o termo dos outros signos lingüísticos é que sua extensão semântica se define em relação ao significado, mais do que em relação ao significante: o que importa, em terminologia, não é saber o que significa tal forma lingüística, mas qualé a forma lingüística que representa uma noção (idem ibidem).

Para Le Guern, é imprescindível distinguir as palavras no léxico das palavras no discurso.

O léxico é um estoque de palavras, independentes das coisas. O léxico de uma língua é, portanto, o conjunto das palavras dessa língua. Segundo a terminologia peirceana, as palavras do léxico são legisignos (quanto ao signo em si) simbólicos (quanto ao signo em relação com o próprio objeto) remáticos (sob o ponto de vista do signo em relação com o interpretante). As palavras no léxico são o resultado de uma convenção arbitrária (type) e não possuem conexão física com o objeto que indicam, ou seja, não estão em relação imediata com as coisas. Têm significado, porém não têm referência e exprimem apenas um conjunto de propriedades. Com as palavras do léxico tem-se a ilusão do substantivo, porém elas só falam de propriedades, e não de substâncias, de qualidades, mas não de objetos. (LEGUERN, 1989).

Já no discurso, as palavras estão ligadas às coisas e são sinsignos indiciais remáticos: representam uma singularidade, têm uma conexão física com o objeto que indicam e representam seu objeto em suas características (PEIRCE, 1975, p.100-102) . No discurso, as palavras são substantivos. Se o signo de uma propriedade (no léxico) é um predicado, o signo de um objeto (no discurso) é o termo e os termos são substantivos porque posicionados dentro dos discursos. Para designar objetos, o discurso não lança mão só do léxico, mas também da sintaxe, gerando uma unidade mínima de significação que é o sintagma nominal. Os termos, então, não fazem parte do léxico, porque são construídos no discurso.

A lógica do léxico é diferente da lógica do discurso. A Terminologia, por sua vez, está do lado do discurso. A lógica clássica opõe extensão e compreensão, o que se aplica ao discurso, mas não é um modelo adequado para se falar da representação do léxico. Para se falar de extensão, deve-se considerar um referencial, um universo constituído de objetos que pertencem ou não à extensão considerada. No léxico, as palavras só têm intensão. Uma palavra significa independentemente de qualquer universo que seja, constituindo, assim, um predicado livre. Já a colocação da palavra no discurso configura uma associação da palavra a uma classe de objetos determinados e constitui predicados vinculados (predicats liés). Os predicados vinculados são como etiquetas de classes de objetos tomados num dado universo. Os léxicos são intraduzíveis, mas os discursos não. " $\mathrm{O}$ léxico considera as palavras, a terminologia considera as coisas" (idem ibidem, p.342), e é por isso que, na perspectiva da Terminologia, pode-se ter etiquetas para a mesma classe de objetos de um dado universo em duas ou mais línguas. Os termos, neste caso, têm a mesma extensão dentro do universo de referência. A tradutibilidade é, neste caso, fundada numa sinonímia referencial. "Se dois termos têm a mesma extensão num dado universo, pode-se considerá- 
los como equivalentes e traduzi-los um pelo outro" (idem ibidem).

A tradução depalavras do léxico (predicados livres)é impossível porque, numa perspectiva cognitiva, "os objetos e as classes de objetos se opõem por traços de substância, em número variável segundo os indivíduos, porque isso depende do saber, da experiência e da cultura de cada pessoa. As palavras na língua são analisadas em semas ou predicados elementares. O significado de uma palavra dada não é constituído da totalidade dos traços de substância associados ao objeto que essa palavra designa habitualmente, mas éresultado de uma escolha coletiva, ligada à história da língua e à sua estrutura. Cada língua faz sua escolha ... Enquanto só os semas são pertinentes para o léxico, os empregos em predicados vinculados podem mudar por um efeito de contexto e dos traços de substância das classes de objetos que eles designam, mesmo se eles não forem retidos pela língua para constituir os significantes lexicais... São os traços de substância que são pertinentes em terminologia, não os semas”(LE GUERN, 1990, p.342).

Segundo Le Guern, portanto, a palavra não é o veículo do conceito, uma vez que as línguas particulares utilizarão várias formas para expressar as unidades do pensamento e é por isso que a Terminologia explora a noção do conceito vinculando-o ao termo, não à palavra, buscando, assim, a univocidade na comunicação. A definição dos limites de significação de cada termo é feita através das “atividades", ou melhor, das línguas de especialidade das atividades.

Para Desmet, os termos, enquanto sistemas organizados, refletem uma organização conceptual(DESMET, 1990,p.5).Apoiando-se em Wüster, para quem uma unidade terminológicaé "um símbolo convencional que representa uma noção definida num certo domínio do saber", Desmet retira três idéias fundadoras:

“. a importância do conteúdo, que é uma noção ou conceito;

. a necessidade de que esta noção ou conceito seja descrita ou definida explicitamente;

. a descrição da noção remete-a para um determinado domínio do saber, do qual ela é solidária, integrando-a num sistema de noções” (DESMET, 1990, p.5-6).

A confusão entre definição da palavra e definição da coisa (que ao nosso ver é análoga à distinção entre palavra no léxico e palavra no discurso, de Le Guern) implica, ainda hoje, a coexistência de dois paradigmas semânticos para a descrição do sentido em terminologia, segundo Desmet. Tal fato seria resultante da própria ausência de uma definição rigorosa do que seja "definição". O primeiro deles encaminha à definição lexicográfica (a definição da palavra), "resultado de uma aplicação da análise fonológica à análise semântica". DESMET, 1990, p.7). "Vivemos ainda a herança da procura de traços mínimos para a descrição do sentido das unidades" (idem ibidem). O segundo - ainda não sedimentado - "defende uma certa pertinência da clássica distinção entre 'definição da palavra' e 'definição da coisa"' (idem, p.5), ou seja, procura delimitar o que seria uma definição terminológica, distinguindo-a da definição lexicográfica (DESMET, 1990). 
"Um termo para ser termo - isto no plano nocional - precisa ser distinguido de todo e qualquer termo, num dado domínio de conhecimentos" através de uma operação de "definição" (idem ibidem, p.6): "o termo não funciona a partir do melhoramento do uso do nome. O termo funciona enquanto termo" (idem ibidem, p.8). A definição de uma unidade terminológica passa, necessariamente, pela delimitação do conceito. "A definição terminológica é, por excelência, classificadora, hierarquizante, estruturante”(DESMET, 1990, p.6).

Para Kocourek (apud HERMANS, 1989, p.8) “o termo é uma unidade lexical definida nos textos de especialidade. O termo científico é uma unidade lexical definida num texto científico e a condição para ser termo é a de ser definido no discurso científico. Como decorrência, todo termo deve ser monossêmico, unívoco, prescritivo (HERMANS, 1989, p.529).

A concepção de termo, segundo a vertente expressa na maior parte das normas terminológicas, está assentada no "modelo de termo" de Wüster, uma releitura do triângulo de Ogden \& Richards. Segundo Felber, a partir desse triângulo e das teorias de Saussure, Wüster elaborou um modelo compreendendo quatro campos. "Só existem duas relações fundamentais nesses quatro campos, a saber: objeto individual-noção e símbolo-significação"(FELBER, 1987, p.84).

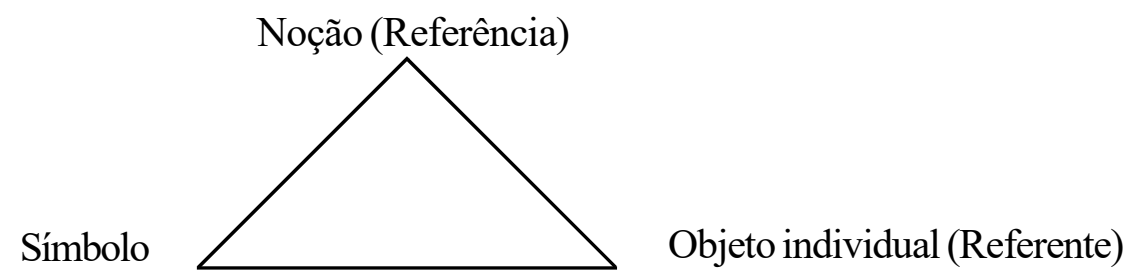

(Entre parênteses; termos utilizados por Ogden em 1923. FELBER, 1987, p.84)

Modelo do termo de Wüster:
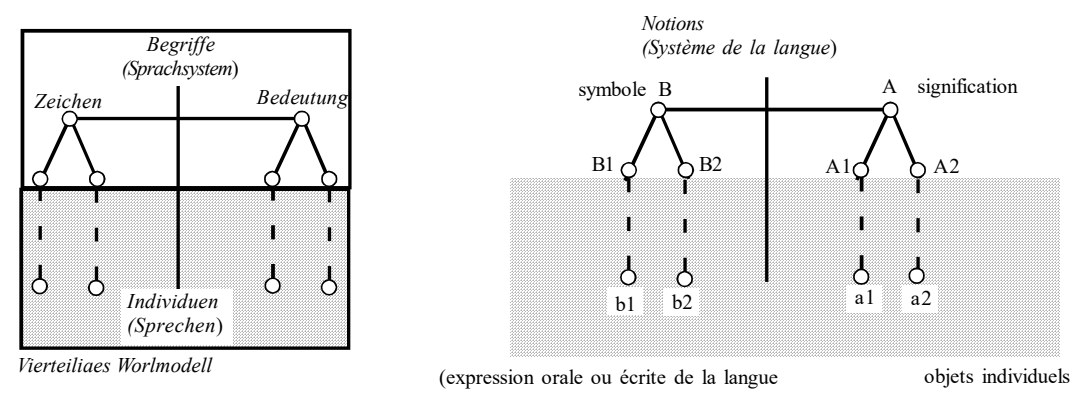

\section{Legenda:}

a1, a 2 ... Objetos individuais que possuem um certo número de propriedades comuns

A1 Noção individual, ou seja, conjunto de características que exprimem as propriedades do objeto indivudual a1.

A2 Noção individual, ou seja, conjunto de características que exprimem as propriedades do objeto individual a2.

A Noção abstrata que corresponde às noções individuais A1 e A2. Essa noção é um conjunto de características comuns a A1 e A2.

B Noção de um símbolo língüístico. Essa noção consite em um conjunto de características que definem sua configuração ou sua forma fônica. $\mathrm{B}$ é ligado à $\mathrm{A}$, que é a significação de $\mathrm{B}$.

B1, B2 ... Noções individuais de uma forma fônica ou gráfica.

b1, b2 ... Formas fônicas ou gráficas (representações da noção B).

(FELBER, 1987. Modelo do termo de Wüster, p.84). 
Na avaliação de Rastier, as origens da Terminologia - seja considerando Wüster(Escola vienense) ou Drezen (Escola soviética) - ainda hoje estão presentes sob diversas formas canônicas, como no manual de Felber (patrocinado pela Unesco/Inforterm e Unisist) ou na norma ISO. O triângulo terminológico de Wüster é, para Rastier, uma reformulação do triângulo semiótico da tradição aristotélica - cujos vértices são a palavra, o conceito e a coisa - endurecidos, entretanto, pelo positivismo lógico que exprime um ideal de correspondência ... entre uma palavra, um conceito e um objeto.

A relação da palavra ao conceito, no seio do triângulo semiótico, repõe as questões da polissemia, de um lado, e mediatamente, da referência, o que revela uma ontologia realista como testemunha a história mesmo do conceito de termo. Segundo a tradição aristotélica os conceitos, mais do que as coisas, não variam com as línguas, o que coincide com a proposta das normas ISO que afirmam que as noções (ou conceitos) que exprimem os termos não são ligados às línguas individuais (RASTIER, 1995, p.37-39).

De fato, o estatuto do termo provém de uma visão dualista do conhecimento segundo a qual os conceitos científicos são incompatíveis com aqueles do mundo cotidiano. Alíngua comum, segundo essa visão, descreveria o mais baixo nível de abstração do conhecimento e produziria significações “emotivas" e "não-cognitivas"(SLODZIAN, 1995, p.14).

Nas raízes do "termo" está a lógica terminista, que é essencialmente uma teoria da suposição (hoje, denotação), fundada na Inglaterra com a corrente nominalista, mãe da filosofia analítica e do positivismo lógico de onde procede o projeto wüsteriano. A lógica terminista é, essencialmente, uma teoria da referência dos nomes, que na sua versão parisiense é não-contextualista e defende a idéia de que o termo é provido de uma significação natural, ou mais precisamente, uma extensão pré-preposicional (RASTIER, 1995, p.38).

Ao recolocar a relação palavra-conceito-coisa, o triângulo wüsteriano reafirma que, mais que o conceito, julgado universal, o referente não varia. Não somente porque as coisas 'são as mesmas para todo mundo', como disse Aristóteles, mas porque o ser ele mesmo se define como permanente. Segundo Rastier, isso se deve aos fundamentos da ontologia de Parmênides, que tem por primeira conseqüência o programa de univocidade da escola eleática. Wüster menciona a ontologia como uma das disciplinas conexas à Terminologia, e no triângulo semiótico clássico, ela é identificada à coisa que garantiria o conceito que a representa e, por essa mediação, a univocidade da palavra.

A proposta wüsteriana (e de forma derivada, as normas terminológicas) é, portanto, substancialista, pressupondo a permanência da essência como fundamento da unidade do sentido. Se, como afirma Wüster, os conceitos ou noções correspondem ao sistema da língua, como explicar que os conceitos dependeriam do sistema da língua uma vez que eles não diferem segundo as línguas? ... 
O problema da interpretação é rebatido aqui sobre a referência: se a referência do signo é fixa, sua interpretação, no sentido lógico, não apresenta nenhuma dificuldade... (RASTIER, 1995, p.40).

A Terminologia é, para Rastier, tributária da filosofia da linguagem, e privilegia o pensamento mais do que a linguagem. Como a filosofia da linguagem, ela tem uma 'obsessão nominal' e pressupõe que o nome reflita a entidade, herança da filosofia pré-socrática. "Ainda hoje, na definição do nome, o valor ontológico permanece freqüentemente preeminente sobre os critérios morfológicos. .... Conforme, também Charaudeau, 1992, p.21: 'Os seres são expressos por uma categoria tradicionalmente chamada nome ou substantivo'. Esses postulados não se apóiam sobre nenhuma base empírica ... [e] são da ordem da crença" (RASTIER, p.40-41).

Para o autor, é duvidoso que o nome - e o verbo - seria a categoria gramatical mais rica do ponto de vista da informação semântica veiculada. Essa justificativa discutível poderia ser compreendida com a suposição de que a referência de uma proposição é assegurada por seus termos categoremáticos. Essa crença, que repousa sobre pré-julgamentos ontológicos, é assimilada pela Terminologia (idem ibidem, p.42-43).

Por outro lado, a noção de sistema terminológico concebe que os termos são ligados entre eles por relações 'conceptuais' fora do discurso, como acontece nos sistemas nocionais que correspondem à ontologia dos domínios de especialidade utilizados para a representação do conhecimento em Inteligência Artificial. Para Rastier, também o programa de 'representação do conhecimento' da IA deve muito à tradição aristotélica reelaborada pelo positivismo lógico, notadamente do primeiro Wittgenstein. Através do uso do triângulo semiótico a IA arma suas redes colocando em correspondência as leis da natureza, do pensamento e da linguagem. Porém, se as redes estudam melhor as relações verticais fundadas na equivalência parcial dos nós, têm problemas para representar as relações fundadas na diferença dos nós, como as relações causais, como também todas as relações lingüísticas. Para Rastier, a representação de campos de conhecimento por conjunto de termos redobra o postulado nominalista de que um domínio empírico é um conjunto de entidades individuais. Se os termos são o ponto de referência, "deve-se convir que os textos instauram entre eles, modificam e problematizam, relações bem mais ricas não retidas pelos diversos formatos de representação do conhecimento. Os textos não são de fato palavras, e um domínio não pode se reduzir a uma coleção de indivíduos”(Idem ibidem, p.44-45).

A abordagem de Rastier tem o mérito de levantar restrições à Terminologia no que diz respeito às heranças positivistas integradas às normas terminológicas. De fato, a Terminologia - e a Documentação, como já afirmamos - são mais felizes ao descrever as escolhas efetuadas no eixo paradigmático. A constituição do termo, sob seu ponto de vista, deveria ser feita em direção à sintagmatização, a partir da recuperação de contribuições da semântica textual, para evitar as 
reduções advindas do isolamento dos termos dos discursos de especialidade. Para o autor, é preciso considerar as determinações contextuais, bem como as determinações globais que o termo recebe do texto para a definição de sua significação, considerando a posição dos termos e suas ligações com as estruturas textuais.

\subsection{A definição}

A literatura terminológica privilegia o conceito de objeto, discutido mais acima, afirmando que essa noção é fundamental em Terminologia porque permite realizar a distinção entre trabalho terminológico e trabalho lingüístico. Se na lingüística não há primazia do significado sobre o significante, na Terminologia a forma significante não é fundamental: há primazia do conceito sobre a forma.

Se para a lingüística o importante é a pergunta "o que significa" - que remete ao uso que faço da palavra - para a Terminologia interessa a relação da palavra com o que está fora da linguagem (o que é) (DUBUC, 1977, p.6; RONDEAU, 1984, p.19). Para a lingüística (na análise componencial, por exemplo) interessam as propriedades da palavra (embora a definição de Pottier esteja próxima da definição terminológica); para a Terminologia irão interessar as propriedades do objeto. Isso explica o privilégio da lógica para a organização das terminologias, através da identificação das relações entre as propriedades do objeto.

A ênfase no extralingüístico se dissolve, entretanto, se substituirmos 'referência' por ‘contexto'. Passa-se a abordar as 'propriedades do objeto' através da palavra, não privilegiando sua materialidade física, mas a resultante cultural construída em função de determinados objetivos.

Para Baccega, o reflexo da realidade na linguagem/pensamento não é mero reflexo passivo, nem reprodução. A especificação e valor dos objetos e a nossa interação com estes objetos decorrem do universo lingüístico ao qual pertencemos. "Só podemos tomar consciência dessas relações na medida em que elas significam, e elas significam apenas por meio da linguagem" (BACCEGA, 1995, p.40).

Segundo Tálamo, o entendimento do mundo como um conjunto de objetos exteriores "só existe enquanto atividade humana sensível e é apreendida necessariamente de modo subjetivo. Portanto a linguagem fornece o meio e o motivo para se passar do mundo das idéias para o mundo real... É a realidade imediata do pensamento .... e é também realidade simbólica, razão pela qual corre o risco de se apresentar com uma determinada autonomia" (TÁLAMO, apud BACCEGA, 1995, p.40). 
A referência dos termos na Terminologia é formulada através de uma operação de definição. Segundo a norma ISO 1087, uma definição é um "enunciado que descreve um conceito e que permite diferenciá-lo de outros conceitos no interior de um sistema de conceitos", podendo ser formulada de duas maneiras básicas: definição por compreensão (ou intensão) que "compreende a menção do conceito genérico mais próximo - já definido ou supostamente conhecido - e das características distintivas que delimitam o conceito a ser definido; definição por extensão, que baseia-se na "enumeração exaustiva dos objetos aos quais se refere um conceito ou dos conceitos específicos que lhe estão imediatamente subordinados"(ISO 1087).

A norma ISO 704 não diz o que seja uma definição, mas ressalta que a delimitação de um conceito obriga, antes, a "analisar sua intensão ou extensão".

Afirma Sager que a definição é uma explanação aceita do significado especializado, de itens lexicais cuja ocorrência pode ser documentada em várias fontes (SAGER, 1990, p.39). A definição fixa a intensão do termo, mas a precisão com que ela vai realizar essa fixação varia do extremo rigor à flexibilidade.

Para Dahlberg, “fazer uma definição equivale a estabelecer uma 'equação de sentido', sendo, de certo modo, uma 'limitação' cuja função é 'determinar ou fixar os limites de um conceito ou idéia'. A definição é a “delimitação ou fixação do conteúdo de um conceito (conteúdo do conceito = intensão, ou o conjunto de características ou atributos") (DAHLBERG, 1978, p.106).

Distingue-se, entretanto, a definição terminológica e a definição lexicográfica. A definição terminológica (ou terminográfica) consiste em "descrever, delimitar, distinguir os conceitos", remetendo à concepção wüsteriana de unidade terminológica enquanto "símbolo convencional que representa uma noção definida num certo domínio fundador" (WÜSTER, apud DESMET, 1990, p. 6). Como a definição aristotélica, a definição terminológica implica na demarcação de um limite.

Considerando os domínios do saber, as terminologias constituem os "sistemas definicionais" que refletem sua organização estruturada e delimitada. Conseqüentemente, a definição terminológica é "classificadora, hierarquizante, estruturante" e ainda herda o paradigma semântico que procura "traços mínimos para a descrição do sentido das palavras", o que significa confundila com a definição lexicográfica. Entretanto, a definição terminológica relaciona-se à definição da coisa, enquanto que a definição lexicográfica à definição da palavra. A definição terminológica deve buscar "definir o conceito e não um significado", o que implica a necessidade de estabelecer um "jogo de conceito a conceito" determinando as relações que os unem. Assim sendo, "a unidade de sentido que deve ser trabalhada é o conceito ou noção, que difere substancialmente 
do significado. O significado mantém um laço de indissociabilidade com o significante. O conceito, não, é uma unidade muito mais livre". A operação que vai de conceito a conceito é a base de uma semântica relacional (idem ibidem, p. 7-8).

A definição terminológica liga-se à definição aristotélica: “a definição é uma proposição que exprime o que a palavra significa (...) A palavra é signo da proposição (...) A definição e a significação de uma palavra não podem ser dadas por uma outra palavra, mas somente pela proposição" (ARISTÓTELES, Segundas Analíticas, apud DESMET, 1990, p. 9). Segundo a autora, as reflexões dos filósofos iluministas permitiram à Terminologia compreender a distinção entre a definição da palavra e a definição da coisa: "a definição da palavra é uma explicação do que a palavra significa dentro da língua; a definição da coisa é "uma relação entre uma idéia (o definiendum) e outras idéias (o definiens)...Definir no sentido da definição da coisa consiste em dizer que uma idéia contém outra" (inclusão) (idem ibidem, p.9-10).

O fato de que a evolução da ciência é mais rápida do que a evolução da língua explicaria as confusões entre a definição da palavra e a definição da coisa, já que "o conceito resiste à descrição porque estamos no âmbito dos conhecimentos"... e é "mais fácil reduzir o conceito a um mero significado (portanto, intralingüístico)". Como na definição aristotélica, a definição terminológica consiste num “jogo de proposições em que as unidades não são palavras, mas noções" (idem ibidem, p.11-12).

A ótica de Desmet remete, entretanto, à Wüster quando ela destaca a necessidade de partir de conceitos (procedimento onomasiológico). As propriedades semânticas do conceito seriam como os predicados da lógica, e os conceitos inteiros constituiriam conjuntos coerentes de juízos sobre o objeto, refletindo suas características; igualmente, os conceitos manteriam entre si relações espaço-temporais (ontológicas). A definição terminológica, em resumo, inclui a definição genérica e a partitiva, bem como a definição funcional. Ou seja: têm-se uma definição por compreensão quando ela "designa uma classe geral à qual pertence o conceito definido, especifica-o distinguindo dos outros conceitos da mesma classe e enumera os caracteres que pertencem ao conceito" (DESMET, 1990, p. 15-16).

Dentre as espécies de definição abordadas por Dahlberg, a definição real e a definição nominal se assemelham à definição terminológica e à definição lexicográfica discutidas por Desmet. A definição real procura delimitar a intensão de um conceito e a definição nominal, a fixar o sentido de uma palavra. A definição real relaciona-se com o conhecimento do objeto. Sua finalidade é "apresentar o conhecimento contido em determinado conceito" (DAHLBERG, 1978, p.106). Já a definição nominal "procura fixar o uso de determinada palavra” (idem ibidem). 
Diferentemente do que postula a maior parte da literatura terminológica, para Rastier a definição seria inconciliável com uma teoria do contexto e do texto, porque supõe que a significação possa ser independente dos contextos, ou que ela os contêm como em germe. Supõe, também, uma abordagem transcendental do significado, porque toda definição necessita de 'primitivos'. Na realidade, a definição seria, antes, um gênero textual, que se revelaria como uma paratax $\mathrm{e}^{25}$ porque "exclui as marcas da enunciação representada... [e] supondo um contrato interpretativo" (RASTIER, 1995, p.53-54).

A definição de Rastier aproxima-se da definição dialética, que diferentemente da definição lógica "não descreve uma realidade, mas uma tomada de posição em relação à realidade (BOURCIER, 1976, p.119).

\subsection{A construção da definição através das normas ISO 704 e ISO 1087}

Uma vez determinado o objeto, para a Terminologia trata-se de estabelecer as relações entre as propriedades do objeto relevantes para cada domínio. Através da operação de definição, circunscreve-se o objeto relativamente a outros no mesmo domínio (ou domínios correlatos). Constrói-se, portanto, uma definição analítica, nos moldes da definição lógica.

De um modo geral, tais relações são tratadas de forma semelhante pelas duas normas, muito embora a faceta mais "extensional" da norma ISO704 - e portanto, o uso da lógica formal acabe por tornar suas afirmações mais categóricas. Destaque-se, por exemplo, a definição de intensão e extensão de um conceito, na norma ISO 704:

. a intensão de um conceito "consiste nas características que o constituem ou definem"; . a extensão de um conceito "abrange todos os conceitos a eles subordinados".

Na norma ISO 1087, as definições de intensão e extensão são as que se seguem:

. compreensão: conjunto das características que formam um conceito; . extensão: conjunto dos indivíduos aos quais um conceito pode se aplicar.

Reafirma-se a observação feita anteriormente em relação à proposta brasileira de versão da norma ISO 704 que concebe as características como inerentes aos conceitos, fato relativizado pela norma ISO 1087 (também na sua proposta de versão nacional) ao utilizar o termo “conjunto”. 
Quanto às relações entre as noções, a norma ISO 704 distingue as relações lógicas das ontológicas (o que não é feito na norma ISO 1087). Vejamos o resumo abaixo:

\begin{tabular}{|c|l|}
\hline ISO 1087 & ISO 704 \\
\hline Rel. hierárquicas & Rel. hierárquicas \\
Rel. genéricas & \\
Rel. partitivas & \\
Rel. não-hierárquicas & Rel. seqüenciais \\
Rel. seqüenciais & \\
Rel. pragmáticas & Rel. lógicas \\
& Rel.subord. (genéricas) \\
& Rel. ontológicas \\
& Rel.partitivas \\
& Rel.seqüenciais \\
\hline
\end{tabular}

Nas duas normas, as relações seqüenciais referem-se à contigüidade espaço-temporal que constituem, para Dahlberg, relações funcionais (DAHLBERG, 1978, p.105). Na norma ISO 704 as relações de dependência espaço-temporal também são definidas como sendo de contigüidade lógica, mas não são classificadas como lógicas.

A relação pragmática só é contemplada pela norma ISO 1087 e considera as possibilidades de associação com base em contextos sócio-culturais. Este é um tipo de relação característica de uma semântica de base intensional. Sob certo ângulo, pode-se afirmar que todas as relações são, em certa medida, pragmáticas, sendo umas mais estáveis e compartilhadas (as identificadas como lógicas) do que outras.

Embora existam divergências entre a identificação e classificação das relações entre conceitos, existem basicamente dois modos através do qual elas se organizam. Um primeiro, diz respeito à sua forma de apresentação: as relações se organizam vertical ou horizontalmente e podem ser representadas, graficamente, como árvores. Um segundo modo diz respeito à natureza das relações em jogo, onde se verifica a existência ou não de subordinação propriamente lógica (contemplando os princípios da lógica das classes e o encaixe lógico). Considerando-se a natureza das relações elas são classificadas como lógicas, não-lógicas (ontológicas) e pragmáticas. Muito provavelmente as relações pragmáticas seriam identificadas como um tipo de relação ontológica, para a norma ISO 704, se se considerar que o contexto sócio-cultural define o espaço onde se dão as relações entre conceitos, bem como circunscreve-os num determinado período de tempo. 


\subsection{A dificuldade para a definição de termos relativos a objetos indeterminados}

Para a Terminologia clássica o termo é o produto de uma relação extralingüística que parte do objeto e é mediada pelo conceito. A abordagem dita "extralingüística" põe em evidência a crença na dicotomia sujeito/objeto, conforme a construção abaixo:

\section{OBJETO $<=====\Rightarrow$ CONCEITO $<=======>$ TERMO}

Entretanto, pode-se verificar que há termos que não têm objeto, ou pelo menos, cujo objeto é relativamente indeterminado. A ausência desse objeto dificultaria, pois, sua definição referencial.

Hermans distingue dois tipos de termos no vocabulário científico: os termos técnicos e os termos 'para conceitos"” (HERMANS, 1989, p.529). “Os termos técnicos designam observações, medidas, experiências, instrumentos etc. Esses objetos são, logicamente, preexistentes aos termos. Para constituir a terminologia de um domínio técnico parte-se desses objetos, de suas noções, às quais são atribuídas termos, correspondendo à decupagem do campo nocional. $\mathrm{O}$ termo não é definido a partir de seu funcionamento no discurso, de sua significação na sua polissemia eventual, mas como correspondendo a uma noção particular dentro do campo nocional" (idem ibidem, p. 529).

Já os “termos teóricos não se relacionam às noções preexistentes ou a representações mentais de objetos concretos ou abstratos. Ao contrário, eles são utilizados com uma ou várias significações. Sua significação depende de seu funcionamento no contexto" (HERMANS, 1989, p.529-530) ...Um termo teórico deve ser estudado e definido no seu ambiente e segundo os paradigmas nos quais figura. Sua significação depende de relações que ele mantém com os outros termos do enunciado, que o delimitam, e relações privilegiadas entre certos termos num enunciado ou disciplina dada. Um conceito tem, então, simplesmente, a significação de um termo. Não é possível, conseqüentemente, construir uma árvore nocional de seus conceitos para estruturar previamente um domínio (idem ibidem).

“A significação dos termos científicos é continuamente gerada pelo uso que os cientistas fazem dos termos e pela maneira como tal uso é compreendido pelos outros" (HERMANS, 1989, p.530). Esse movimento contínuo das ciências pode gerar termos imprecisos. "Esta imprecisão não provém de uma incapacidade de ser preciso, mas se funda na pesquisa científica propriamente dita. A estabilidade, nas ciências, equivale à estagnação. Elas procuram, portanto, "uma instabilidade próxima do equilíbrio entre determinação e indeterminação. Se os conceitos científicos são muito determinados, eles não funcionam mais como instrumentos de descoberta ou de explicação" (idem ibidem).

Contrariamente aos termos técnicos cujos objetos são muito determinados, os conceitos teóricos 
são indeterminados. “A precisão é obtida sacrificando-se sua significação. Eé graças a seu caráter metafórico e conotado que esses termos teóricos funcionam como elementos heurísticos e explicativos dentro da atividade científica... toda ciência se funda sobre uma operação de metaforização, onde os deslizamentos de sentido, as analogias e a ambigüidade dos conceitos de base fornecem as hipóteses e guiam a observação" (p.530) “... "várias significações de um termo coexistem dentro de uma mesma disciplina científica ...” (idem ibidem).

A ausência de um objeto determinado, pois, dificulta a operacionalização de uma definição analítica nos moldes previstos pelas normas. Sua identificação permite explicar a dificuldade de operacionalizar definições em domínios em formação, transformação e/ou eminentemente trans e inter-disciplinares. A definição, nestes casos, aproxima-se mais de uma definição lingüística. A diferença entre definição terminológica e definição lexicográfica reside no tipo de análise semântica realizada. A lexicografia parte do signo para chegar à determinação do conceito (procedimento semasiológico) e a terminográfica parte da noção e pesquisa os termos que lhe correspondem (procedimento onomasiológico). Mas a abordagem onomasiológica é útil apenas quando temos um sistema conceptual estável e coerente e onde às noções correspondem objetos. Aplica-se, portanto, aos termos técnicos.

A definição dos termos teóricos seria semasiológica, porquanto sua significação depende de seu funcionamento nos textos. "A definição de termos teóricos consistirá na especificação das diferentes significações que podem ter esses termos (especificações cronológicas, por escola de pensamento, por substrato teórico no qual o termo aparece), de seu valor heurístico, de seu caráter metafórico e eventual, suas conotações, de sua polissemia e da economia lingüística que lhes conferem essas características" (HERMANS, 1989, p.530).

Uma definição teórica tambéméconcebida como “aquela que tenta formularuma caracterização adequada aos objetos que se aplica. Propor uma definição teórica equivale a propor a aceitação de uma teoria e... as teorias são notoriamente discutíveis. Disso resulta que uma definição é substituída por outra à medida que nosso conhecimento e compreensão teóricos aumentam"(COPI, 1978, p.117).

Um gênero de definição teórica também é encontrada em Deleuze e Guattari: “O conceito definese por sua consistência ... mas não tem referência; ele é auto referencial”... não é discursivo... É a confusão do conceito e da proposição que faz acreditar na existência de conceitos científicos, e que considera a proposição como uma verdadeira 'intensão' ... O conceito não é, ... uma proposição... e a proposição não é nunca uma intensão. As proposições definem-se por sua referência, e a referência não concerne ao acontecimento, mas a uma relação com o estado de coisas e de corpos, bem como às condições dessa relação. Longe de constituir uma intensão, estas condições são todas extensionais; implicam em operações de enquadramento em abcissas 
ou de linearização sucessivas que fazem os dados intensivos entrar em coordenadas" (DELEUZE \& GUATTARI, 1992, p. 34-35)

Por analogia, o conceito (dos autores acima) corresponderia ao termo teórico, porque é só intensão. O conceito ligado ao termo teórico não é uma proposição no sentido de que não tem referente extralingüístico, resolvendo-se no próprio interior do discurso (ou contexto onde aparece). A proposição estaria mais ligada ao termo técnico que se remete a objetos bem determinados. Definido que é, a partir de uma referência, ele é extensional, o que permite (e explica) o uso de relações de encaixe de classes. “... e a independência das variáveis nas proposições opõe-se à inseparabilidade das variações do conceito" (idem, p. 35).

Essa proposta reforça a hipótese de Hermans sobre a distinção entre conceitos teóricos e técnicos. O primeiro, não se submete, a rigor, à uma definição analítica, contrariamente ao que ocorre com o conceito técnico. De fato, as definições para um termo técnico podem ser realizadas a partir do uso da lógica formal, num esquema básico de inclusão/exclusão, equivalência, não-contrariedade, ou seja, seguem os mecanismos de dedução/indução. Já os termos teóricos assemelham-se a isótopos, cujos componentes se combinam de maneira mais livre e não precisam (e não podem) obedecer às relações da lógica formal.

As normas terminológicas não pressupõem essa distinção e tratam todos os termos como se eles fossem termos técnicos. A distinção entre definição lexicográfica e definição terminológica (postulada por Desmet e por outros autores) apenas determina a ênfase - lingüística ou lógica - para o tratamento dos termos. A aproximação da definição terminológica à definição analítica mostra a preponderância da lógica nos parâmetros para a construção da definição adotados pela Terminologia clássica, o que explica a dificuldade de sua utilização para os domínios onde não se verifica uma estabilidade conceitual.

\subsection{A terminologia onomasiológica e a terminologia semasiológica}

As normas terminológicas se omitem quanto à discussão sobre a elaboração de terminologias em domínios cujo objeto se caracteriza por "transformações". De fato, a terminologia clássica é mais onomasiológica, que corresponderia, segundo a abordagem de Béjoint, eminentemente a uma terminologia da denominação.

A terminologia onomasiológica é “ancorada na referência” (BÉJOINT, 1989, p. 407), e coloca em jogo uma semântica extensional que tende a se "conformar ao princípio humboldiano (biunívoco) ... segundo o qual uma só forma deve corresponder a um só sentido e vice-versa" (idem ibidem, 
p.408). Na terminologia da denominação, portanto, não faz sentido falar em monossemia stricto sensu, mas, talvez, em univocidade (idem ibidem).

Béjoint bem observa que, embora se pressuponha que a atividade dos "verdadeiros" terminólogos seja eminentemente onomasiológica, procedimentos semasiológicos constituem a base de grande parte de seu trabalho. Trata-se, entretanto, de uma semasiologia "um pouco particular". Isto porque o inventário dos sentidos possíveis de cada forma - característica do trabalho semasiológico - é, na maior parte do tempo, voltado à circunscrição do domínio explorado; em seguida, porque, se as formas são geralmente extraídas do discurso, seus sentidos não são diretamente extraídos de seus comportamentos discursivos (BÉJOINT, 1989, p.409). Na realidade, a semasiologia "particular" a que se refere, junta procedimentos de natureza semasiológica e onomasiológica.

A concepção de termos correspondente a tais procedimentos indica que "não há solução de continuidade entre o termo e a palavra (o que não quer dizer que não se possa distingui-los) e que todo termo, a partir do momento em que se insere nos discursos diferentes dos discursos ‘fundadores' que o definem, é susceptível de se ‘desterminologizar'” (BÉJOINT, 1989, p.409).

A descrição das tarefas de um terminólogo evidencia o fato de que o inventário consiste em, "a partir de uma ocorrência de uma forma em discurso (a 'unidade lexical, no sentido de Lyons), procurar outras ocorrências da mesma forma (ou seja, de uma das formas possíveis do lema) para compará-las..." "Cada ocorrência tem um e um só sentido no discurso, mais ou menos próximo da definição comumente aceita. O trabalho consiste, então, em reagrupar as ocorrências por afinidades semânticas para constituir conjuntos que serão tratados como unidades (os ‘lexemas’ de Lyons). Em Terminologia, intuitivamente, pode-se prever que teremos mais casos onde as ocorrências de uma mesma forma corresponderão a um mesmo lexema (donde os casos de monossemia), do que em um léxico geral. A dificuldade está em colocá-las em evidência” (idem ibidem).

Para Béjoint, existe certa dose de espontaneidade, de intuição, na tarefa do terminólogo, o que o leva, muitas vezes, a atribuir sinônimos contextuais (elementos lexicais ou paráfrases do tipo definicional) a cada ocorrência de uma mesma forma, reagrupando, depois, as ocorrências que correspondem à mesma paráfrase (supondo a aceitação da hipótese mel'chukiana segundo a qual o sentido é a invariante das transformações sinonímicas). Mas tais operações de substituição só podem ir até certo ponto (BÉJOINT, 1989, p.409-410).

Estudos que explorem a utilização quantitativa e qualitativa de ambientes lingüísticos de cada ocorrência - "as colocações"-, poderiam contribuir à exploração dessa vertente de trabalho. "A idéia ... é que a complexidade semântica de um lexema se manifesta pela quantidade e 'variedade' das colocações pelas quais ele entra num corpus: mais um lexema é rico semanticamente, mais 
suas colocações serão numerosas e 'variadas'. Um lexema polissêmico terá, portanto, mais colocações diferentes, e diversas, que um lexema monossêmico' (idem ibidem, p.410).

Uma proposta semelhante significa um avanço frente aos procedimentos da Terminologia clássica porque, ao considerar os ambientes lingüísticos onde ocorrem os termos, admite-se a hipótese de considerar a variação a partir do uso. A Terminologia clássica, ao contrário, aceita a univocidade, quando afirma que "um termo, por definição, é sempre monossêmico" (ISO 704).

\subsection{A proposta da Socioterminologia}

A Socioterminologia é uma área de pesquisa que levanta várias objeções à teoria da Terminologia mais tradicional. "A Socioterminologia deve levar em conta os aspectos sociolingüísticos da comunicação científica e técnica. ... Ela trabalha o termo técnico sob uma ótica que parte do signo lingüístico. ... A Socioterminologia se interessa pelas práticas institucionais que visam a observação, o registro e a organização das práticas da língua nos processos tecnológicos “ (DUBOIS, J. et al., 1994, apud BOULANGER, 1995, p.198).

O termo "Socioterminologia", embora tenha sido utilizado pela primeira vez em 1981 por JeanClaude Boulanger, só em 1987, com a publicação de um artigo de Yves Gambier na revista Meta, passa a refletir a existência de um esforço teórico e de uma posição original na interface terminologiasociolingüística. Atualmente, a pesquisa em Socioterminologia congrega pesquisadores ligados principalmente à Universidade de Roeun, na França, mas também tem representantes em outros países, como na Rússia (Marusenko e Kandelaki) e no Canadá (Louis Guilbert e Monica Heller). A proposta principal da Socioterminologia é a revisão da Terminologia clássica, particularmente de inspiração wüsteriana.

A noção de Socioterminologia também se articula com a glotopolítica (preocupação encontrada nos trabalhos de Louis Guespin e Foued Laroussi, 1989), e com a editologia (reflexões de Louis Guespin sobre as modalidades editoriais de circulação dos termos). Outro eixo importante da Socioterminologia é o exame das relações entre terminologia e trabalho, através da pesquisa de vocabulários profissionais (Gambier e Gaudin, 1989) (GAUDIN, 1993).

A Socioterminologia levanta diversas críticas à terminologia clássica:

1. A perspectiva sincrônica, deixando de considerar a história;

2. A obsessão pela recomendação e normalização e pela purificação do termo;

3. A ênfase no aparelho da descrição terminográfica (fabricação de dicionários para áreas científicas) e enfoque na resolução do enigma do termo/não termo. 
Embora a Socioterminologia reconheça resultados satisfatórios particularmente na construção de dicionários, volta sua crítica à ausência de discussões sobre o papel da Terminologia na construção dos discursos e sobre as relações entre o termo e o signo lingüístico. Para a Socioterminologia, as primeiras descrições e prescrições terminológicas foram feitas a partir do uso de uma equação redutora do signo lingüístico.

À noção "deveria corresponder um significante obrigatoriamente monossêmico, sem tolerar qualquer concorrente sinonímico que fosse" (idem ibidem).

De fato, para a Socioterminologia, a terminologia clássica não considera a diversidade das situações de comunicação. O postulado da biunivocidade termo-conceito implica o não reconhecimento da polissemia e da pertinência da sinonímia, o que sem dúvida, é um reducionismo. Tira-se do termo seu direito à variação, tanto do ponto de vista semântico como lexical.

A Socioterminologia propõe a revisão do processo de prescrição terminológica alterando a relação recomendação/normalização consideradas simultaneamente, para a relação recomendação/ normalização após um tempo de observação. Essa seria uma condição para passar a considerar o uso real dos termos para só, então, adotar uma atitude prescritiva. Propõe, conseqüentemente, uma revisão das atitudes da terminologia frente à sinonímia. O que a Socioterminologia advoga é que só a consideração dos aspectos lingüísticos da questão terminológica colocaria um fím ao reducionismo lexical e um reavivamento dos jogos sociais (BOULANGER, 1995, p.196).

Também é proposta da Socioterminologia incluir o discurso socioprofissional nos quadros da terminologia. Segundo o grupo de Roeun, toda terminologia nasce do social e a ela deve retornar. O retorno ao terreno que é lugar do exercício da terminologia passa a considerar os discursos sociais como fundamentais, enquanto lugares da palavra. A reancoragem no social induziria, como decorrência, à novas abordagens teóricas e metodológicas de temas como o das práticas lingüísticas não departamentalizadas entre as ciências e as técnicas e o conseqüente questionamento da separação entre línguas de especialidade e língua geral. Como decorrência, a Socioterminologia considera que a descrição deve preponderar sobre a prescrição.

Para Gambier, a quem se deve a maior parte das propostas da Socioterminologia, é necessário abordar as ciências e técnicas sob o ângulo de nós de conhecimento. "Um domínio é constantemente o resultado da dialética entre a integração (interdisciplinar) e a parcelização (hiperespecialização)". Os discursos funcionam em sinapse e em tempo real, frente ao caráter fechado das imposições da Terminologia. "Uma ciência, uma técnica refere-se a outras ciências, outras técnicas - elas mesmas ramos sobre outras ... Não há ‘domínio' sem ‘domínios' conexos: um ‘domínio’ remete a um nó de conexões - tanto mais aberto, instável quanto mais novo for o saber, em curso de constituição, 
sem definição consensual” (GAMBIER, 1991, p.37 apud BOULANGER, 1995, p.198).

A Socioterminologia enfatiza, também, a importância da história: pela ótica diacrônica, a perspectiva lingüística inclui a história social. Uma terminologia diacrônica poderia pesquisar as causas dos equilíbrios e desequilíbrios onomasiológicos. As estratégias da Socioterminologia são estruturadas na perspectiva da integração social dos discursos terminológicos: os termos, mas também a sintagmática no sentido saussuriano, constituem o suporte frástico dos enunciados. Sob essa ótica, a Socioterminologia se oferece como a conjugação do léxico, da gramática, da sintaxe e, indiretamente, da fonologia, já que ela se faz discurso falado (BOULANGER, 1995, P.199).

As contribuições individuais da Socioterminologia questionam alguns conceitos da Terminologia clássica: Guespin, por exemplo, discute a pertinência dos conceitos de 'língua de especialidade', 'sinônimo', 'domínio', e a cópula 'ciência e técnica'; a noção de 'domínio' também é discutida por J.C. Baudet. Para Gaudin, o termo 'língua de especialidade’ é ambíguo, devendo ser substituído por 'episteme': a terminologia seria, então, uma "meta-disciplina fundada sobre uma abordagem lingüística” (GAUDIN apud BOULANGER, 1995, p.199). Para este autor, é impossível definir uma língua de especialidade sem lhe reconhecer um oponente. Gaudin discute também, a oposição dicotômica entre a homonímia e a polissemia, pregando a recuperação da força polissêmica dos signos. Para ele, o terminólogo não faz outra coisa senão descartar ou rejeitar o sentido de uma unidade lexical que não convém à sua estruturação omasiológica. A homonímia generalizada é um mito redutor. A consideração da sincronia como norma é uma das principais fontes da fratura artificial entre a homonímia e a polissemia. Ao reintroduzir a história e a diacronia na terminologia, a homonímia e a polissemia reencontram sua justificação no conhecimento e no funcionamento das práticas lingüísticas ativas (BOULANGER, p.199-200).

\subsection{A Terminologia (e as terminologias) e a Documentação}

Em prefácio à obra de M. Teresa Cabré, Sager, ao se referir às várias posições frente a Terminologia, afirma que a dificuldade derivada dessa discussão decorre do fato de que pouco sabemos sobre o que seja informação e sobre a complexidade de qualquer processo de comunicação. Trata-se, normalmente, de forma separada, a linguagem e as disciplinas de especialidade, ou o conhecimento e a forma apropriada de sua expressão. A aprendizagem de uma segunda língua - seja ela um idioma estrangeiro ou a língua de determinada especialidade - se faz, sempre, através da primeira, porém, não se dá conta, habitualmente, da sua interação, enão se presta atenção, conseqüentemente, "ao delicado equilíbrio que existe entre a língua geral e as linguagens especializadas pela temática, responsáveis pela eficiência da aprendizagem e da posterior utilização do conhecimento adquirido na comunicação" (SAGER, 1993, p.13-14). 
A divisão entre língua geral e línguas de especialidade, com suas terminologias específicas, "se encontra na base da estrutura que nossa sociedade dá ao conhecimento e às profissões que a representam. O estudo da terminologia pressuporia a recusa da concepção da língua enquanto instrumento unitário e funcional, e a aceitação, em troca, de uma concepção da língua como um conjunto de diversas linguagens de variado grau de especificidade, que colocam em comum um grande número de elementos fonológicos e morfológicos, um número menor de elementos sintáticos e uma coincidência semântica, até o ponto de permitir uma função metalingüística num nível mais geral" (idem ibidem, p.14).

O domínio que especialistas têm de sua disciplina, seu vocabulário e de seu primeiro idioma, é sempre parcial, sendo fortemente determinado por fatores educacionais, culturais, profissionais etc. Por outro lado, tradutores, intérpretes, documentalistas e terminólogos “ocupam uma posição de ponte entre a linguagem e as disciplinas de especialidade, entre o conteúdo e o instrumento". Conhecem a linguagem de uma disciplina, mas não conhecem a disciplina como a 'conhece' um especialista(idem ibidem).

Existem, além de linguagens separadas, níveis de saber diversos: o saber de um tradutor ou de um terminólogo pode diferir do saber de um intérprete ou um documentalista e, também, do 'saber fazer' do engenheiro e do biólogo. Saber uma língua é, portanto, diferente de saber construir uma ponte. Além de níveis de compreensão de disciplinas existem, ainda, diversos níveis de linguagem.

Para Sager, portanto, o estudo da terminologia é complexo, pois deve satisfazer inquietudes distintas: dos especialistas da disciplina, do público em geral, e finalmente, a dos mediadores da comunicação, que têm que saber como fazer frente às necessidades de seus clientes.

Para Cabré, o objetivo da normalização terminológica é a transferência do conhecimento. Por conseqüência, normalizar significa padronizar para melhor compreender: o empobrecimento da língua é feito em favor da comunicação. Porém, a transferência do conhecimento deve prever todos os domínios de comunicação onde a terminologia tenha um lugar, não se restringindo aos domínios de especialistas no seu sentido estrito. O trabalho terminológico deve compreender, pois, o léxico comum e o léxico especializado, sob o ponto de vista do produtor e do consumidor. Além disso, as atividades terminológicas não se limitam à prescrição e normalização, devendo ser descritiva particularmente em domínios onde não se pode normalizar a terminologia (domínios profissionais em via de desaparecimento) ou onde é muito difícil normalizar (várias disciplinas sociais e humanas onde a impossibilidade de isolar conceitos provoca uma multiplicação de pontos de vista e uma diversificação conceptual do mesmo objeto) (CABRÉ, 1991).

Os termos são unidades pragmáticas. A Terminologia, porém, tem dado muito pouca atenção ao 
estudo dos termos enquanto unidades comunicativas do discurso especializado. As propostas interdisciplinares que se ocupam da linguagem como ferramenta de expressão e de comunicação, agrupadas sob o rótulo de 'lingüística aplicada', têm na pragmática, o campo que se ocupa da descrição do uso da linguagem, e não de seu conhecimento. A pragmática, porém, deve se relacionar com outras disciplinas, como a Sociolingüística, a Psicolingüística, a Antropologia e a análise do discurso, entre outras (CABRÉ, 1991, p.220-221).

A abordagem pragmática dos termos permite, segundo Cabré, diferenciar o léxico comum da terminologia, a partir:

a) da função básica a que se propõem: conativa, emotiva, fática, poética e metalingüística $\mathrm{x}$ referencial;

b) da temática de que tratam: genérica x específica;

c) dos usuários: gerais x especializados;

d) das situações comunicativas: menos formalizadas x mais formalizadas;

e) dos tipos de discurso: gerais x profissionais e científicos (idem ibidem, p. 221-222).

Budin, por outro lado, postula que a Terminologia não deve ser vista de forma isolada, destacando que uma descrição policêntrica da modelagem da informação e sistemas de conhecimento revela a multivariada natureza das relações entre conhecimento, informação e comunicação. Abordagens cartesianas tradicionais acabam por reduzir o grau de complexidade dos sistemas de conhecimento ao representá-los através de simples visões estruturais.

A informação consiste em conhecimento que foi 'empacotado' numa forma estrutural tal que possa ser comunicada a uma comunidade mais ampla e potencial de usuários, e é a terminologia a ferramenta primária para gerar esse conhecimento empacotado. Porém, se a terminologia pode ser definida como a estruturação total dos conceitos relativos a um campo especializado, é necessário considerar que a designação dos signos e termos para conceitos é uma atividade humana sujeita à cultura específica e aos pontos de vista individuais. Sua proposta é prover uma abordagem holística e policêntrica, onde conhecimento, informação, comunicação e terminologia possam manifestar-se no nível do sistema e no nível organizacional, podendo ser vistas tanto segundo uma perspectiva estática (condições e unidades do conhecimento, informação, comunicação e terminologia) como em termos de critérios dinâmicos (processos e procedimentos). Conhecimento científico, informação, comunicação e terminologia devem ser vistos num contexto sócio-pragmático em que interferem inúmeras variáveis (BUDIN, 1997, p.190-192).

A abordagem necessária da Terminologia para a Documentação deve ser feita equilibrandose o formalismo e necessidades pragmáticas. Enquanto atividade mediadora, a Documentação recorre a 'várias línguas' (no sentido de Sager), e entre elas, à Terminologia, como fonte para 
a estruturação das linguagens documentárias e como referência para a delimitação da significação de suas expressões.

A variação dos modos de assimilação da Terminologia corresponde aos diferentes aspectos enfatizados na mediação (que também caracteriza a atividade terminológica) e aos diferentes pressupostos utilizados: mais próximos à posição dos terminólogos ortodoxos, quando a tônica estiver centrada na lógica, na normalização e na prescrição; mais próximos à posição dos terminólogos que consideram a atividade terminológica como caracterizada pelo uso de vários subcódigos lingüísticos, quando a tônica recair na descrição.

A concepção de representação documentária que adotamos requer o uso crítico das recomendações. O lado prescritivo da Documentação decorre da impossibilidade de representar textos individualmente, razão pela qual procuram-se formas relativamente canônicas correspondentes aos modos mais ou menos consensuais de reconhecer assuntos e conceitos (o uso da forma nominal criticada por Rastier representa o modo mais consensual de representar sinteticamente).

A Terminologia tradicional fornece respostas adequadas para o tratamento das informações canônicas, porém o mesmo não acontece com informações cujo estatuto não está assegurado enquanto padrão compartilhável. Por outro lado, não há como ignorar o fato de que a semiose, mesmo na presença de referenciais para a interpretação, não está livre de se desenvolver em função dos outros interpretantes da enciclopédia de cada usuário individual. Esta é uma das razões pelas quais questionamos a prescrição e a normalização estritas, buscando apoio, também, numa Terminologia mais descritiva.

Esse procedimento fica claro na preocupação de se utilizar relações de equivalência entre vocabulários (do produtor e do usuário) como meio de contemplar a recepção. Na mesma direção, a utilização de vários pontos de acesso a partir dos quais a informação possa ser conceptualizada (facetas ou pontos de vista, de um lado e relações associativas nãohierárquicas, de outro, enquanto recurso para mostrar ocorrências de sintagmatização). Com o mesmo objetivo, a utilização de formas de definição que não configuram uma definição ao modo clássico (recomendação da Terminologia para a veiculação de significações unívocas). De fato, o uso de definições semióticas (ou enciclopédicas, no sentido de Eco) permite, muitas vezes, escapar às restrições de significação de uma definição clássica. Há casos em que não há consenso sobre uma definição, ou o conceito apresentado está sujeito a revisão. Como exemplo, veja-se a definição a seguir, construída para o acesso a dados pontuais, que pretende registrar um conceito cujos limites já não são absolutamente delimitados: 


\section{TAXA DE URBANIZAÇÃO}

Percentual da população urbana em relação à população total calculado, geralmente, a partir de dados censitários, segundo a fórmula:

População urbana X 100

População total

OBS.:

1. As categorias rural e urbana de uma unidade geográfica são, no Brasil, definidas por lei municipal. Os critérios para determinar se um domicílio fica na zona rural ou urbana são políticos e variam, portanto, de um município a outro.

2. Em relação aos domicílios, o IBGE, órgão responsável pelo Censo Demográfico, identifica duas situações:

a) em "situação urbana" estão os domicílios que se localizam em áreas urbanizadas ou não, correspondentes às Cidades (Sedes Municipais), às Vilas (Sedes Distritais) ou às Áreas urbanas Isoladas;

b) em "situação rural" estão os domicílios que se localizam fora dos limites acima definidos, inclusive os Aglomerados Rurais de Extensão Urbana, os Povoados e os Núcleos.

As definições de Cidade, Vila, Área urbana Isolada, Aglomerado Rural de Extensão Urbana, Povoado e Núcleo são, em primeiro lugar, legais, seguidas de características relacionadas à presença ou não de construções, arruamentos, edificações e ocupação urbana. Uma vez que o critério para definir se uma área é urbana ou rural é eminentemente legal (conforme as Leis Municipais de Zoneamento), a interpretação das taxas de urbanização só poderá ser feita nos limites dessa definição.

FONTE: Base de dados terminológicos - Fundação SEADE

Além disso, a prescrição de definições segundo a Terminologia clássica funciona de modo coercitivo e supõe um entendimento do processo de comunicação centrado apenas no emissor (no especialista). Não considera, também, o caráter pedagógico que uma definição possa assumir se se explicitam dúvidas quanto à sua delimitação. Do mesmo modo, não supõe que a interpretação é um processo que envolve a utilização de diversos subcódigos lingüísticos e, assim procedendo, acaba por não incorporar o receptor como sujeito da interpretação. A prescrição supõe, necessariamente, o empobrecimento da língua como único meio de operar a circulação de informações.

As linguagens documentárias consideradas como instrumento de mediação devem realizar, como observa Sager, a ponte entre esses dois tipos de 'léxico', corroborando uma hipótese de código que não trabalhe apenas com o código científico, mas também com o código semiótico que dê 
conta de necessidades socialmente fixadas. Como afirma Eco, existe um hiato entre certeza 'científica' e 'certeza 'social', que constitui a diferença entre leis e hipóteses científicas, de um lado, e códigos semióticos, de outro (ECO, 1991, p.49). Não é possível, pois, ignorar que para a interpretação de um código concorrem vários elementos - inclusive o pragmático - sendo a interpretação não um simples processo de equivalência mas, também, de inferências. "Basta que dois sistemas se entrelacem ... e eis que o chamado código (já sistema de vários códigos) não é mais apenas um aparato que fornece equivalências, mas uma máquina que fornece instruções para manobrar diversos sistemas de equivalências em diversos contextos e circunstâncias" (idem ibidem, p.284). Numa dimensão pragmática, o código assume o aspecto de uma enciclopédia.

Na realidade, a mediação realizada pelos códigos documentários se realiza como referência contínua de código a código. A interação é regulada por uma variedade de códigos - a terminologia entre eles - , a ponto de não se poder afirmar, mais, a preponderância da imposição de um código sobre outro. Existem códigos mais fortes e menos fortes, porém um código "não pode ser apenas uma cifra: será uma matriz que permite infinitas ocorrências, a nascente de um jogo" (idem ibidem, p.290). 


\section{PARA UMA DELIMITAÇÃO DO CONCEITO DE REPRESENTAÇÃO DOCUMENTÁRIA}

As discussões sobre a representação na Filosofia, na Lingüística, na Semiótica e na Terminologia contribuem, sob diversos aspectos, à delimitação de um conceito de representação documentária. Neste capítulo procuraremos sistematizar essas contribuições.

\subsection{Função das representações documentárias}

A Documentação, e mais especificamente, a Análise Documentária, relaciona o conceito de representação ao resultado das operações de análise e síntese do conteúdo de textos cujo objetivo é a transferência de informação.

As representações documentárias constituem uma construção levada a efeito a partir de um olhar sobre o que se considera, para determinados fins, informação. As definições de informação, entretanto, dependem do aspecto que privilegiam, sendo que as mais correntes estão preocupadas com sua caracterização a partir da adequação de processos comunicacionais entre emissor e receptor da mensagem. Observada a partir do gerador, considera-se a informação como "resultado da relação estática entre objetos materiais, independente da ação de seres humanos". A partir da mensagem, "é identificada como símbolos produzidos por um gerador para efetivar um processo de transferência" (BARRETO, 1994, p.3). Já quando relacionadas ao receptor, "reforçam a intensão semântica da transferência, adjetivando o conceito com o significado da mensagem, seu uso efetivo e ação resultante do uso". Porém é o conceito de informação associado à "produção de conhecimento no indivíduo" que pode melhor explicar a natureza do fenômeno. Observar a informação a partir da sua qualificação como "elemento modificador da consciência do homem e de seu grupo" leva a entendê-la como uma "organização em si", e não como simples medida de organização, seja a partir do enfoque da geração, ou da recepção. Desse modo, a informação é um agente mediador na produção do conhecimento e qualifica-se, em forma e substância, como estruturas significantes com a competência de gerar conhecimento (idem ibidem, grifo meu).

De fato, as representações documentárias que são nosso objeto, podem ser analisadas como “estruturas significantes" intimamente ligadas à função de produção do conhecimento. Sob este ângulo, a função das representações é a de exercer a mediação, agenciando a produção do conhecimento para modificar os estoques de informação dos indivíduos e das sociedades.

Porém, parafraseando Barreto, pode-se dizer que as representações documentárias são o resultado de atividades orientadas para a organização e o controle de "estoques de informação", mas sua 
natureza estática implica em que não necessariamente produzem, por si só, qualquer conhecimento: apenas possuem a competência para produzi-lo através de uma ação de comunicação mutuamente consentida entre a fonte e os receptores (BARRETO, 1994, p.4). Essa ação mutuamente consentida decorre do fato de que a compreensão é adesiva, e envolve uma relação de pertença ao que nos rodeia (GADAMER apud NUNES, 1998, p.10). A interpretação é fruto do desenvolvimento das possibilidades de compreensão, não se realizando na ausência de um pressuposto. Em situações documentárias, portanto, é necessário tornar claros tais pressupostos, como condição para o desenvolvimento da compreensão e da interpretação. Entretanto, não existe, normalmente, compromisso direto e final entre produção de estoques / produção do conhecimento.

Por outro lado, a informação é sempre ambivalente (BAITELLO JÚNIOR, 1994, p.19). As sociedades constituem-se "não apenas agregando, mas também segregando". É nesse processo de agregação e desagregação, "porta de entrada (e saída) dos agrupamentos sociais ... que nascem os códigos de comunicação (um fenômeno inegavelmente social)" (idem ibidem). A agregação e desagregação são operações construtivas através das quais trocam-se informações "que vinculam e desvinculam" e é no momento em que se estabelecem "rituais de vínculo" que surge, de fato, a informação. "Uma vez que a informação, e com ela a comunicação, nascem de um campo de tensões, de uma situação de incerteza, insegurança e indefinição (tanto que, primordialmente, os vínculos comunicativos têm de ser ritualizados para que thes sejam aplacados os teores de incerteza), os resquícios desta ambivalência, de onde a informação nasce, tornam-se permanentes" (idem ibidem, p.20). É da natureza das representações documentárias, portanto, essa ambivalência, porém, "quando as relações comunicativas se encontram enrijecidas pela excessiva regulamentação ... morrem as ambivalências, sucumbe o fundamento da informação" (idem ibidem, p. 20-21).

Vistas sob este aspecto, confirma-se o fato de que as representações não são etiquetas que se colam às coisas, não constituem nomenclatura. São signos construídos para determinados fins, e como tal, desencadeiam, no processo comunicativo, um tipo de semiose. Não podem ser vistas, por essa razão, como se existisse uma relação biunívoca entre a coisa ou fenômeno a ser representado e a representação ela mesma. É, entretanto, na estruturação das linguagens documentárias que se define o vínculo ou se fixam os pressupostos a partir dos quais se estabelece a hipótese de interpretação. Conseqüentemente, a partir da hipótese de agregação, as representações documentárias podem passar a funcionar como indicadores para a construção da informação.

As representações documentárias constituem uma redução de conteúdos, não só em termos semióticos e sintáticos, como também de competência para geração de conhecimento. Sua função, portanto, é limitada, mais ainda porque o próprio processo de transferência está submetido a restrições: "quem detém a propriedade dos estoques de informação determina a sua distribuição e 
condiciona, potencialmente, a produção do conhecimento" (BARRETO, 1994,p.4). Sob nosso ponto de vista determina, também, o vínculo a partir do qual constrói a hipótese de significação.

O problema das representações documentárias sob o ponto de vista da mediação encontra-se, contemporaneamente, bastante explicitado como fenômeno de linguagem. De fato, se tradicionalmente o enfoque da mediação em Documentação privilegiava a relação sistema-usuário, hoje torna-se claro que ela acontece mais exatamente entre a linguagem do sistema (ou da instituição) e a linguagem do usuário. Do mesmo modo, portanto, que a Informática obrigou a Documentação a explicitar os procedimentos de análise documentária, as novas mídias - e particularmente a Internet - fazem ressaltar que a mediação é um problema de natureza lingüísticocomunicacional.

A função das representações documentárias, nesse contexto, está sobrevalorizada pois, de um lado, não existe a figura do intermediário humano, ponte entre o usuário e as representações do sistema; por outro, a própria figura do usuário se dissolve entre inúmeras figuras potenciais, razão pela qual os sistemas de equivalência assumem enorme importância para o enfrentamento das questões da representação.

\subsection{Tipologia das representações documentárias}

Em nossa dissertação de mestrado ressaltamos a existência de dois tipos básicos de representação documentária: o resumo, produto que mantém relação de contigüidade e semelhança com o texto original, e o índice, obtido a partir do uso de um outro sistema de significação externo ao texto a linguagem documentária (LARA, 1993).

O gênero de representação que mais se aproxima do texto original é, de fato, o resumo documentário. Este constitui uma representação condensada do documento-fonte e pode funcionar como instrumento de decisão sobre a consulta ao texto, uma vez que faz remissão a referenciais de assuntos nele tratados, de modo mais preciso e particularizante. É elaborado utilizando o mesmo sistema semiótico do texto e pressupõe um vínculo estreito com o documento original.

Já os índices são produtos com características mais generalizantes. Construídos através da intermediação de um código comutador genérico - uma linguagem documentária no seu sentido mais tradicional - os índices são produto que têm relativa independência do sistema de significação do texto. Isolados dos textos (ou fontes) de origem, organizam-se, a seu modo, para representar o que se considera informação. Desse modo, vinculam-se apenas indiretamente aos textos, embora considerem os conceitos por eles veiculados. 
Esses dois tipos de representação constituem exemplos extremos. No que diz respeito aos índices é preciso verificar que muitos deles, embora sejam expressos por palavras ou expressões controladas, não se servem de sistemas de significação externos aos textos que constituem seu objeto (melhor dizendo, de linguagens documentárias no seu sentido mais convencional, aplicáveis a vários universos similares de documentos), mas são engendrados no próprio processo de indexação diretamente dos sistemas de significação dos textos eles mesmos: embora constituam sistemas, são aplicáveis apenas aos universos a partir dos quais foram criados. Incluem-se, aqui, os vocabulários controlados e estruturados construídos para universos muito particulares que, embora não possam ser reutilizados de forma mais genérica, não poderiam deixar de ser considerados linguagens documentárias. Existem índices, também, que constituem conjuntos de termos insuficientemente estruturados para constituir um sistema e são apenas uma relação dos termos ou conceitos mais recorrentes. Não se pode dizer, a rigor, que constituam verdadeiramente representações documentárias e linguagens documentárias.

A atividade documentária de representação tende, contemporaneamente, a abranger um espectro bem mais amplo, não se restringindo ao que tradicionalmente se identifica como "documento", meio físico ou suporte constituinte de acervos de bibliotecas e centros de documentação. A introdução de novas mídias para veiculação de informações passa a solicitar que a atividade tradicionalmente identificada e designada como "documentária", constitua-se seja concebida de uma forma mais ampla englobando a "organização e transferência da informação". Produtos gerados num processo similar ao de representação documentária propriamente dita, caracterizam-se como o resultado de organização estrutural da informação cujo foco principal - a transferência da informação - encontra-se, mais do que nunca, enfatizada. É o caso dos trabalhos de arquitetura informacional de sites, definição de meios de navegação na Internet e, de uma forma mais próxima às atividades normalmente identificadas como de "representação documentária", construção de ferramentas de acesso à informação.

Face a essas alterações é lícito propor a flexibilização do conceito de linguagem documentária, para incluir não só os vocabulários controlados que, em diferentes níveis de estruturação, são engendrados diretamente no processo de organização da informação - concepção presente em Gardin, e hoje retomada - como também o gênero de linguagem que se desenvolve no processo de arranjo das informações não identificadas, normalmente, como propriamente documentárias. Dito de outro modo, há vocabulários mais formais que se prestam à indexação pontual de informações, e há vocabulários que mesclam a formalidade de uma linguagem construída e uma relativa informalidade oriunda da Linguagem Natural. A flexibilização do conceito de linguagem documentária desloca, nesse sentido, a centralidade das preocupações, das estruturas significantes, para as estruturas passíveis de significação, e incorpora, com maior ênfase, o usuário, no processo de construção das representações. 


\subsection{Modo de funcionamento e interpretação das representações documentárias:}

Em trabalho anterior (LARA, 1993) afirmamos que o modo de funcionamento da comunicação documentária varia conforme o tipo de representação documentária oferecida ao usuário. Resumos documentários são produtos que desencadeiam um tipo de semiose cujos interpretantes têm como base referenciais presentes nos textos originais objeto de representação. O resumo "simula" o texto buscando proporcionar ao usuário condições de decisão sobre a ida ou não ao texto original. Neste sentido, a representação documentária não chega a interferir demasiadamente na comunicação, pois se atém, sem grandes desvios, ao texto original.

Diferentemente, frente a um índice obtido a partir de uma linguagem documentária externa ao texto, a semiose se desencadeia de modo bastante particular. Uma vez que as referências ao texto original já não estão presentes, a interpretação dos "signos documentários" passa a depender da qualidade do código, do grau de experiência do usuário com esse mesmo código comutador e da qualidade das referências do vocabulário do usuário nela integradas. Verifica-se, comumente, que os código documentários diferem quanto aos níveis de explicitação dos conceitos a que se reportam e que, por outro lado, nem sempre integram referências do vocabulário do usuário como meio de facilitar o acesso. Além disso, os códigos documentários não são, normalmente, disponibilizados ao usuário, o que pode ter como resultado uma interpretação dos signos documentários baseada na experiência com o código da língua (ao modo dicionarial) ou na sua experiência individual.

As observações acima referem-se ao funcionamento das representações documentárias no âmbito estrito dos textos técnico-científicos que, a despeito das diferenças de tipologia, convergem para modos de apresentação razoavelmente padronizados no meio técnico e acadêmico. Além disso, por maiores que sejam as dificuldades de construção das representações documentárias particularmente na área das humanidades - trabalha-se com um usuário de uma comunidade informacional cuja competência, em menor ou maior grau, inclui a possibilidade de decodificação dos sistemas baseada na familiaridade com determinados tipos de vocabulários e determinados tipos de veiculação de informações.

Fora desse âmbito, não se pode esperar que o mesmo padrão de tratamento da informação paute a atividade documentária de representação, sendo necessário identificar diferentes estratégias que observem as especificidades dos sistemas e públicos para os quais são construídos. O modo de representação da informação pública institucional, por exemplo, não é semelhante à dos textos técnico-científicos, como também é distinto seu público. Por outro lado, a disseminação desse gênero de informações é relativamente recente (final da década de 70, início da de 80), coincidindo, no Brasil, com o que se denominou "democratização da informação" (SÃO PAULO (Estado) Secretaria de Economia e Planejamento. Coordenadoria de Análise de Dados, 1978). Para a 
representação desse gênero de informação, não existem padrões ou modelos generalizáveis e eficientes para todos os casos. Adicionalmente, é com os novos meios eletrônicos que a possibilidade de disseminação de informação pública institucional encontra-se potencializada, acrescentando, aos problemas da ausência de modelos de representação, a necessidade de trabalhar com um usuário relativamente indeterminado.

Não se pode afirmar, portanto, como de fato funcionam as representações construídas para esse gênero de informação, razão pela qual é prudente oferecer um maior número de possibilidades de acesso que visem não só explicitar os meios utilizados para a construção da significação, como também incorporar uma preocupação adicional com a sua recepção. A questão da linguagem utilizada na representação/recepção encontra-se, portanto, potencializada na sua importância.

O funcionamento das representações documentárias está submetido às potencialidades de sua interpretação. A interpretação de representações para Peirce, está sujeita ao que ele denomina “experiência colateral”. Frente a uma representação, pode-se ou não identificar seus objetos com uma série de atributos, sendo essa experiência a condição sine qua non para se obter uma idéia significada pelas representações documentárias intermediadas por um código comutador ou linguagem documentária.

Entre diversos condicionantes, a experiência colateral determina em larga medida quando e como as representações documentárias serão interpretadas. O objetivo dos sistemas documentários é o de permitir a transferência da informação, motivo pelo qual meios para a interpretação das representações ou contribuições para o enriquecimento da experiência colateral deverão ser previstos.

Pode-se explicitar o sistema de significação utilizado de diversas maneiras: através de definições formais, de recursos de hierarquização (supondo-se a competência do usuário para realizar raciocínios dedutivos), de sugestão de associações não-lineares (termos relacionados ou remissivas do tipo ver também), utilização da linguagem do usuário - seja através de expressões ou palavras familiares, seja através do uso de equivalências sinonímicas entre os vocabulários do sistema e do usuário etc. Recursos gráficos auxiliam a visualização de diferentes tipos de possibilidades de entrada no sistema (o que considera, além das características do conjunto dos dados em foco, as várias funções, pontos de vista organizacionais e possibilidades de uso da informação). Notas de escopo auxiliam a delimitação do campo de abrangência de um termo; instruções de uso (helps), explicitam os recursos utilizados e seu modo de funcionamento.

A terminologia de domínios exerce, em qualquer caso, uma função extremamente importante relacionada às referências concretas para a interpretação. 


\subsection{O significado do controle da significação na construção das representações}

Qualquer que seja a representação engendrada, ela não pode remeter a uma concepção traducionista do sentido, pois o sentido de um símbolo não é jamais sua tradução por outros símbolos. Esta concepção nos levaria a entender o sentido lingüístico apenas como denotativo (os símbolos designariam objetos do mundo) e, em última análise, a conceber a representação documentária como espelho da realidade. Ao contrário, a representação documentária deve ser entendida como construção - e desse modo a representação documentária é informação (que pode, todavia, ser reelaborada). Neste caso, concebe-se representação documentária como processo: não é espelho. É uma proposta interpretativa.

Sob esse ponto de vista, o conceito de representação documentária pode ser abordado a partir do conceito de representação semiótica. "Representar", para Peirce, significa “estar em lugar de, isto é, estar numa relação com um outro que, para certos propósitos, é considerado por alguma mente como se fosse o outro" (PEIRCE, 1977, p.61). Teixeira Coelho sugere que a teoria peirceana é uma teoria da comunicação ao considerar, por um lado, a forma dialógica de apresentação do pensamento e, por outro, a proposição da relação triádica entre objeto, signo e interpretante, derivada da noção de relação entre enunciador, enunciação e intérprete (TEIXEIRA COELHO, 1990, p.23).

Essa aproximação confirma a necessidade de considerar a representação documentária não só sob a ótica de uma lingüística tradicional, mas de uma lingüística semiótica que possa incluir a abordagem comunicacional. A especificidade da representação documentária obriga a compreendêla como resultante de um processo de "comunicação documentária".

Graus de indeterminação são inerentes à representação dos documentos. Pode-se exercer controle sobre a linguagem utilizada para a representação (sabendo-se que um texto ou a informação objeto de representação nunca poderá ser representada tal como foi originalmente concebida); porém, não é possível controlar integralmente o processo de recuperação, pois cada usuário estabelece, a seu modo, uma formulação baseada na sua experiência colateral e nas suas necessidades particulares.

A função do controle do vocabulário visa operar sobre o significado como meio de garantir a comunicação. Procura-se, através da estruturação vocabular - ou a construção de uma combinatória, no sentido de Greimas - qualificar as representações de modo a garantir uma determinada significação. O relacionamento entre as unidades vocabulares estabelece os vínculos a partir dos quais uma representação ganha um significado determinado. Explicita-se, por outro lado, os vértices adotados para a construção visando garantir a comunicação. 
Os referentes concretos de significado devem ser tomados de empréstimo às ciências e/ou atividades cujos textos ou informações constituem seu objeto. A apropriação das representações documentárias - e a comunicação documentária - depende, portanto, de sua explicitação, porém não é possível afirmar que se restrinja a ela.

De fato, a aprendizagem (e o uso das linguagens documentárias na recuperação) não depende só de definições no seu sentido formal. Blair pondera que o exemplo é mais potente do que a definição, porém sua concepção de definição é muito restrita, pois não considera um dos aspectos mais importantes do funcionamento das línguas naturais: a expansão e a condensação. Uma proposta interpretativa (uma proposta de informação veiculada por uma linguagem documentária) fundamentase numa determinada concepção de organização que tem sua origem na estrutura elementar de significação. As noções que constituem os vértices dessas organizações (emprestadas dos domínios em foco) devem ser explicitadas como meio auxiliar de aprendizagem e compreensão. Considerese, ainda que o exemplo também é um gênero de definição, tal qual as definições por extensão. A identificação das formas de definição a serem utilizadas para explicitar os pontos de partida para a organização do significado dependem de cada caso e situação.

\subsection{As representações documentárias e os usuários}

A noção de controle utilizada para a representação documentária, é muitas vezes interpretada como constrangimento, uma vez que tem características centradas na intencionalidade do enunciador. Porém sabe-se que "a leitura é, por definição, rebelde e vadia” (CHARTIER, 1994, p.7), e um usuário sempre tem a liberdade de se "desviar e reformular" as significações. Sob diversas modalidades, existe uma dialética entre a imposição e a apropriação, já que não existem sentidos fixos, estáveis e universais. Do mesmo modo que se procura fixar o sentido e se deseja conduzir à uma interpretação unívoca, "a recepção também inventa, desloca e distorce” (idem ibidem, p. 9). "Um texto só existe se houver um leitor para lhe dar significado" (idem ibidem, p.11).

A atualização - e a atribuição de significados - depende, também, das formas pelas quais os textos e as informações são recebidos: para além de uma interpretação puramente semântica, é necessário considerar as possíveis alterações decorrentes da modificação dos dispositivos que convidam à sua interpretação. A recepção das representações está condicionada a uma série de fatores, que vão desde as diferentes competências dos usuários, às distintas expectativas frente aos sistemas documentários e, principalmente, às diversas normas e convenções que regem a disponibilização e uso dessas representações.

“Os espaços sociais não são homogêneos como o processamento técnico dos estoques de 
informação" (BARRETO, 1994, p.5) e os sistemas de informação atingem diferentemente os usuários. A realidade da recepção é "multifacetada e formada por micronúcleos sociais com divergências ... profundas" (idem ibidem). Diferenças e aproximações condicionam não só o uso e a assimilação da informação, mas antes de tudo, a possibilidade mesma de acesso e atualização.

Os sistemas de informação podem distribuir informação segundo diferentes estratégias: visando atingir grandes grupos homogêneos de receptores, objetivando grupos diferenciados que compartilham interesses e necessidades comuns ou elaborando sistemas de forma a contemplar elites informacionais com alta capacidade de reelaboração da informação. Sob esta perspectiva, procura-se harmonizar produção e consumo da informação. Porém, a disponibilidade e o acesso não significam, naturalmente, uso efetivo que produz conhecimento (idem ibidem). A atualização da informação, portanto, não se restringe à intencionalidade do emissor.

Sob a perspectiva da demanda, segundo leitura feita por Barreto da pirâmide das necessidades humanas de Maslow, três grandes segmentos de informação podem ser visualizados. Na base da pirâmide, estaria um maior contingente de pessoas, cujas necessidades informacionais estariam voltadas à satisfação de necessidades básicas: necessidades de alimentação, saúde, habitação, vestuário, saúde, educação, enfim, todas aquelas necessidades cujo atendimento permitiria prover o indivíduo de segurança. Este segmento da população demanda informação utilitária. Num segundo segmento, estariam aqueles indivíduos que, já não tendo resolvido problemas de segurança, “orientam-se para um comportamento participativo e por uma vontade de pertencer aos grupos em que participam, seja no trabalho, na comunidade, afetivos ou profissionais" (idem ibidem). Este grupo demanda informações de natureza contextual que lhes assegure a continuidade da sua vinculação aos grupos a que pertencem. "No topo da pirâmide estariam aqueles indivíduos que, tendo satisfeito as necessidades anteriores", podem pretender à auto-realização: buscam informações seletivas que levem ao exercício da reflexão, criatividade ou realização pessoal (idem ibidem, p.6).

Do ponto de vista da relação representações documentárias X usuários, pode-se identificar, através da pirâmide das necessidades informacionais proposta por Barreto, os diferentes níveis de tratamento da informação. Seguindo o modelo, quanto mais se sobe em direção ao topo, maior é a competência do usuário em manipular os sistemas de representação e, conseqüentemente, mais fácil a tarefa de construção das estruturas de significação para decodificação.

Nos sistemas técnico-científicos onde domina a estabilidade conceitual, o reconhecimento das representações é realizado à base da identificação dos termos descritores aos termos do sistema de significação da área de especialidade. Quando essa estabilidade não está garantida ou não é característica do domínio (seja pela sua natureza, seja pela realidade de domínio em formação ou transformação), há maior necessidade de explicitação das referências conceituais. Em ambos os 
casos - e particularmente no primeiro - a constituição das linguagens documentárias é mais formalizada, aproximando-se da Linguagem de Especialidade propriamente dita. As equivalências entre vocabulários poderiam, nestes casos, ser reduzidas às variações de designação, até porque as comunidades técnico-científicas têm, mais do que outras, o hábito de consultar sistemas de informação e, como decorrência, maior familiaridade ou facilidade para manejar modelos convencionais de representação da informação.

Nos sistemas intermediários, característicos das instituições profissionais, associações de grupos de interesse, instituições públicas governamentais, a consulta a sistemas de informação é de natureza mais esporádica, condicionada à satisfação de necessidades pontuais. Quanto à designação das informações, tais universos mesclam, muitas vezes, o jargão profissional, o técnico-científico e a linguagem comum. Forjado que é no interior das próprias instituições, o jargão profissional nem sempre é compartilhado por entidades similares e de mesma natureza e menos ainda, por cidadãos comuns. Além disso, o vocabulário dessas instituições carece de fixação terminológico-conceitual. Esse conjunto de características solicitaria que o trabalho de construção de linguagens documentárias fosse bastante amplo, compreendendo: coleta das variações de designação, procedimentos de fixação terminológica, construção de jogos de equivalência semântica entre vocabulários, estabelecimento de rede relacional entre os termos e desenho das possibilidades de acesso. $\mathrm{O}$ vocabulário desses sistemas situaria-se entre a Linguagem de Especialidade e a Linguagem Natural (ver Anexo, exemplos 1 e 2).

No caso de sistemas de informação utilitária - raros no Brasil-o modelo dos sistemas convencionais de informação e representação não é, necessariamente, válido. A informalidade da linguagem do usuário que demanda por informações utilitárias solicitaria que a construção das representações fosse realizada o mais próximo possível da Linguagem Natural. Além do uso de formatos de acesso simples e claros, esses sistemas devem tender a utilizar a oralidade como padrão (ver Anexo, exemplo 3).

É preciso observar que se aparentemente do topo para a base a construção das representações deveria apresentar níveis decrescentes de formalização, na realidade a alteração de padrões nos discursos das ciências acaba por impor uma revisão global dos modelos de representação. O modelo mais formalizado deixa de ser referência para os distintos sistemas de informação incluindo os próprios sistemas convencionalmente identificados como técnico-científicos.

Se a filosofia, através de Rorty e Santos, já indicava a dissolução das fronteiras entre o discurso da ciência e do senso comum, a mesma percepção ocorre entre representantes da Socioterminologia. Para Hermans, a releitura de Simmel e Durkheim e das propostas do pragmatismo dos anos trinta de Dewey, mostra que as ciências passam a ser consideradas como realidades sociais sui generis, 
um mundo de idéias e práticas que obedece a leis que lhe são próprias. Uma ciência não é condicionada pela realidade social, mas é uma realidade social ela mesma (HERMANS, 1995, p.225). Como corolário, passa-se a questionar o quadro teórico da Terminologia clássica, basicamente wüsteriana, substituindo-o por uma proposta que enfatize o "funcionamento real dos termos, na sua dimensão interativa e discursiva" (GAUDIN, 1993, p.295). O discurso científico, tal como outros, deixa de ser um simples meio de comunicação para transformar-se numa instância ativa em interação com outras instâncias que constituem uma ciência (HERMANS, 1995, p.226).

A análise dos empregos reais dos termos indica que a definição formal de um assunto não é a única fonte dos conceitos (GAMBIER, 1991, p.8). O modelo prescritivo é substituído pelo descritivo, como meio de integrar as práticas lingüísticas como objeto de investigação. À Socioterminologia caberia proceder um nível de análise onde estariam focalizadas as relações entre denominações (enquanto produções lingüísticas) e objetivos conceptuais (práticas sociais), entre trabalho (forças produtivas) e saber/saber-fazer (dinâmica cognitiva) (idem ibidem, p.9). Além disso, ao questionar os princípios positivistas da Terminologia clássica, a Socioterminologia questiona os postulados sobre a monossemia, a biunivocidade dos termos ideais e, conseqüentemente, as proposições normativas/tipológicas que deixam de considerar o funcionamento da língua.

De fato, a experiência com a construção de representações no âmbito dos sistemas de informação não acadêmicos mostra a ineficácia de muitos dos parâmetros da Terminologia clássica. Muitas vezes não se trata de procurar a definição formal de um termo, porém de verificar seu uso (também uma forma de definição). Outras vezes, porém, os parâmetros prescritivos - como a categorização - são o meio através do qual modeliza-se a informação visando introduzir um padrão de reconhecimento e sua transmissão. Dito de outro modo, é preciso encontrar o equilíbrio de estratégias para prover os sistemas de mecanismos de negociação, como meio de garantir a interatividade entre a linguagem do sistema e a linguagem do usuário.

O fluxo de informaçãona pirâmide das necessidades informacionais agrega qualidade no sentido da base para o topo. “Acredita-se que a oferta da informação, ou seja, a estrutura dos estoques, relaciona-se à demanda comouma pirâmide invertida, inversamente proporcional em termos quantitativos e qualitativos às posições da informação demandada"(BARRETO, 1994, p.6). De fato, só muito recentemente tem-se investido na construção de sistemas de informação para a população, porém énesses sistemas que ficam mais evidentes as necessidades de se rever o modelo convencional de representação.

É preciso incorporar, também, à reconstrução do modelo de representação em sistemas de informação, as experiências advindas da disseminação de informações na Internet. Identificam-se, aí, tipos de demandas diferentes, bem como tornam-se evidentes as diferentes competências para usar sistemas de informação. 
De fato, os usuários da informação não são membros de audiências monolíticas que buscam a informação sempre da mesma maneira: alguns usuários preferem buscar por informação a partir de determinadas palavras ou expressões; outros preferem ter uma visão de conjunto das opções de busca do sistema para proceder às suas escolhas. Alguns querem apenas uma pequena informação, enquanto outros querem, de forma detalhada, tudo o que existir sobre determinado tópico. Do mesmo modo, alguns usuários sabem o que querem, mas não sabem como descrever o que desejam; outros sabem formular exatamente o que querem mas não sabem exatamente o que esperam encontrar, e exploram a web para aprender mais. Necessidades e expectativas variam largamente, e os sistemas de informações que os servem devem reconhecer, distinguir e acomodar essas diferentes necessidades. (ROSENFELD \& MORVILLE, 1998, p.102-103).

A ênfase no usuário não dispensa a estruturação do vocabulário, uma vez que é esse procedimento que garante a construção de variadas interfaces. Compare-se, por exemplo, os resultados de busca através do uso de ferramentas de busca (search engines) na Internet, baseadas exclusivamente em recursos de natureza sintática, com aqueles apresentados através do uso de ferramentas semânticas.

\subsection{A representação documentária e conhecimento: limites do modelo tradicional}

O processo de representação documentária é marcado pela intencionalidade, pois deseja-se que as mensagens documentárias obtidas conduzam à uma interpretação. Porém, a informação não é um dado (BACCEGA, 1994, p.10) e o processo interpretativo é de natureza complexa: "não se pode exigir que a $\mathrm{LN}$ decline de sua função também interpretativa e criadora para exercitar apenas a função informativa" (CINTRA et al., 1994, p.54). Embora a LN deva ser integrada à linguagem de representação como meio de operar a interatividade, não é possível, apenas através do seu uso, encaminhar a determinadas interpretações pressupostas pelo sistema. A formalização exerce, nesse sentido, uma coerção, pois pretende-se que as palavras e expressões signifiquem de determinada maneira, mesmo sabendo que a interpretação não é um processo de simples decodificação.

Para cumprir seus objetivos pragmáticos de transferência da informação a Documentação opera com reduções de forma e conteúdo, com o objetivo de propor padrões para a interpretação. Considerada a natureza complexa do processo interpretativo, a construção de um conceito de representação documentária só poderá ser formulado enquanto uma hipótese do que se privilegia como informação. Tratada como hipótese, desfaz-se a noção de que uma representação documentária é de natureza essencialista, pois parte-se do princípio de que a informação é sempre uma construção. De fato, as representações documentárias engendram novas informações. 
Normalmente toma-se a sistematicidade como um dos pressupostos básicos para a construção do conceito de representação documentária. Pressupõe-se tacitamente que a forma reduzida de representação, baseada no princípio da organicidade, seja um fator determinante para a seleção e busca ágil de informações. O modo como concebemos tal sistematicidade implica maior ou menor dogmatismo na construção da representação. É verdade, porém, que ao procurarmos representar com economia comprometemos, muitas vezes, a inteligibilidade da recuperação. Trata-se, na realidade, de utilizar a sistematicidade como princípio ordenador, flexibilizando-se os pontos de vista a partir dos quais atribuímos traços para agrupar e separar procurando tornar explícitas as referências utilizamos para tal ordenação. A ausência total de um princípio de ordenação remetenos ao exemplo citado por Foucault.

Em prefácio à sua obra "As palavras e as coisas" o autor faz menção à uma “certa enciclopédia chinesa", citada por Borges, que comprova nosso "mal estar" frente a falta de pontos de referência a partir dos quais pudéssemos reconhecer e compreender uma dada série de fenômenos:

"os animais se dividem em: a) pertencentes ao imperador, b) embalsamados, c) domesticados, d) leitões, e) sereias, f) fabulosos, g) cães em liberdade, h) incluídos na presente classificação, i) que se agitam como loucos, f) inumeráveis, $\mathrm{k}$ ) desenhados com um pincel muito fino de pelo de camelo, l) et caetera, m) que acabam de quebrar a bilha, n) que de longe parecem moscas "'(FOUCAULT, 1966, p.3).

De fato, a ordem, estabelecida através do reconhecimento de semelhanças, diferenças e aproximações, é um instrumento do conhecimento. A idéia de ordem, entretanto, liga-se à de hierarquia, sistema que pressupõe superordenações e subordinações rígidas. Os vários padrões de ordem utilizados através dos tempos explicam os modos privilegiados de organizar a experiência do mundo.

O conhecimento não se realiza apenas a partir da categorização dos objetos à maneira determinista. Associações não-lineares, reconhecimento de processos, inferências e abduções também são fatores que intervém no modo de se relacionar com o mundo. Conhecer deve pressupor a "possibilidade de ir além das informações ... à capacidade de extrapolar” (MACHADO, 1995, p.34).

A idéia de conhecimento vincula-se à de significado: "conheceré, cada vez mais, conhecero significado", como para Dewey citado pelo autor: "Compreender é apreender a significação... Apreender a significação de uma coisa, de um acontecimento ou situação é ver a coisa em suas relações com outras coisas... Contrariamente, aquilo a que chamamos coisa bruta, a coisa sem sentido para nós, é algo cujas relações não foram apreendidas”(DEWEY, 1979 apud MACHADO, 1995, p.35).

A proposta de uma nova visão do conhecimento é explicitada através da metáfora que opõe rede à cadeia, conforme abaixo: 


\begin{tabular}{|l|l|}
\hline CADEIA & REDE \\
\hline . pré-requisitos & \\
. seriação & . abertura \\
. hierarquia & . heterogeneidade \\
. causalidade & .topologia \\
. organização linear & . fractalidade \\
. lógica & .metamorfose \\
. homogeneidade & .acentrismo \\
. conceitos & .analogia \\
. classificações & . metáforas \\
\hline
\end{tabular}

(MACHADO, 1995: Congresso Brasileiro de Informação e Biblioteconomia, SP)

A utilização da hierarquia parte do princípio de que deve existir alguma “ordem" como princípio de compartilhamento, mas a hierarquia traz em si mesmo sua negação a partir do momento em que se reconhece que suas unidades, no processo de comunicação, podem se relacionar em planos de diferente dimensão. A “cadeia", então, cede espaço à "rede", contemplando relacionamentos que instauram a possibilidade de gerar novos conhecimentos.

A alteração do modo e da própria organização do pensamento é, de fato, característica da modernidade, quando são revistos todos os conceitos fundamentais como o de tempo e espaço, velocidade e deslocamento, que deixam de ser eventos considerados em si para o serem em função do observador. "Tudo é relativo... Alógica aristotélica, que sempre organizara o pensamento humano, vê agora confirmada uma variação; antes, A era igual a A e não era B, isto é, tudo era igual a si mesmo e diferente do outro; agora, as relações tornam-se dialéticas: A define-se em oposição a um B que não é A, nem B e, sim, algo que os engloba e supera. Nada mais é igual a si mesmo o tempo todo (nem num só momento) e sob um mesmo aspecto"(TEIXEIRA COELHO, 1995, p.25-26). As coisas tornam-se, todas, possíveis, porque "uma teoria, uma visão de mundo não supera outra: convive com ela" (como a convivência da física de Newton e a de Einstein) (idem ibidem, p.27).

A construção de um conceito de representação documentária, ao deslocar o foco das essências para o ângulo de observação, relativiza a hierarquia como único meio para organizar e veicular informação. Como no Cubismo, a alteração de parâmetros de representação faz mostrar um objeto sob variados aspectos relativizando-o, embora permitindo sua visão totalizante.

Como para Rorty, a representação não deve ser vista como espelho ou cópia da realidade. A 
crença em essências opõe declarações analíticas sobre o significado de um termo e declarações sintéticas. Não se pode pretender, portanto, que as representações documentárias constituam a imagem exata daquilo que se quer representar. Ao contrário, elas são construídas em função de objetivos, variando sua formulação em face às funções que se deseja enfatizar.

Todas as classificações são construções e, como tal, tornam relevantes (constroem) determinados aspectos em detrimento de outros. O que se identifica como analítico representa o consensual, aquilo que goza de certa universalidade e atemporalidade. O sintético torna-se analítico (no sentido precedente) quando ganha estabilidade. O pressuposto essencialista, contrariamente, supõe a validade constante de um princípio de herança de propriedades relegando a um segundo plano associações não-linerares.

Conceber a representação documentária sob essa ótica significa, pois, considerar que tais construções obedecem a objetivos funcionais, o que reitera a hipótese de que as representações são válidas apenas temporal e circunstancialmente. O princípio de 'utilidade' (combinando o ponto de vista do enunciador e do enunciatário) define os aspectos a serem privilegiados numa representação. Não se trata de 'identificar' as essências das coisas e fenômenos - como se determinadas características fossem parte integrante das coisas e não meios a partir dos quais realizamos as associações - porém de prover agrupamentos a partir de critérios que elegemos para compreender e organizar o mundo. Não 'reconhecemos' as características dos objetos ou fenômenos a representar, mas 'construímos' artificialmente critérios através dos quais possamos formular uma hipótese de ordenação.

Nesse sentido, o conceito de verdade se relativiza, subsidiário que é do que se determina temporariamente como princípio para o estabelecimento de hipóteses, questionando-se, conseqüentemente, critérios que separem verdades analíticas de verdades sintéticas. Desse modo, a delimitação de um conceito de representação documentária depende de 'postulados' tomados caso a caso, que são, por sua vez, eminentemente culturais ou funcionais.

Como afirmou Boaventura Santos, os critérios de classificação não são mais do que o resultado de concepções pragmáticas: a verdade não é definida sem uma inserção prática. Não se questiona se uma representação é ou não verdadeira, admitindo-se como verdade o valor que serve de premissa à uma argumentação. A verdade é, pois, de natureza retórica.

Um conceito operacional de representação documentária deve incluir a noção de verdade múltipla e de diversidade. As representações documentárias são construções desenhadas a partir dos valores admitidos em cada caso. Na estrutura de uma combinatória documentária os termos se relacionam interna e necessariamente: a verdade de cada item de representação resulta do extrato 
que lhe dá sentido, porém constituem simultaneamente uma prescrição e uma proscrição. As representações documentárias são interpretações sujeitas à revisão.

\subsection{Representação documentária e possibilidades de apropriação da informação}

Para trabalhar a partir de um novo conceito de informação é preciso lembrar que no universo documentário tradicional a informação era considerada um dado, fato que marcou fortemente a formulação das linguagens documentárias convencionais. Pressupunha-se que a ativação daquilo que era considerado conteúdo de um documento (noção, aliás, absolutamente imprecisa) deveria ser feita a partir de uma combinatória universal, tal como foi o caso dos sistemas bibliográficos e enciclopédicos de classificação já citados. Analisadas a partir das contribuições da Lingüística contemporânea, pode-se verificar que as características dessas combinatória remetem a uma articulação dura entre o plano do conteúdo e o plano de expressão porque pressupõem um lugar de enunciação fixo, o que permite (e implica) que ela se mantenha inalterada quando enunciada.

Vimos anteriormente que os sistemas de classificação bibliográfica são essencialmente de natureza dedutiva e utilizam uma noção de conceito da lógica aristotélica pautado numa relação de identidade tautológica. Não há, pois, a partir dessas linguagens, possibilidade de apropriação efetiva - a dedução não acrescenta - sendo o resultado de sua aplicação apenas a reprodução do conhecimento. Como decorrência, não há possibilidade de comunicação documentária, dominando tão somente a difusão.

A aceitação do conceito de informação como uma construção não permite mais trabalhar com as propostas que realizam distinções apenas a partir das características dos documentos (de bibliotecas, de arquivos, de museus etc.) (SMIT, 1998, p.4-5). Ao contrário, é sua função informativa que deve ser privilegiada, o que impõe o uso de uma noção de conceito empírica, porque é ela que permite formular classes segundo distintas funções e realizar distinções segundo o que se privilegia a partir dessas funções.

Adicionalmente, é preciso verificar que a atualização da informação por parte do usuário obedece a condicionantes particulares. Como destacou Gaudin, "a vulgarização se desenvolve primeiramente não segundo uma lógica de difusão dos saberes, mas segundo uma lógica da apropriação dos saberes, em função da cultura daqueles aos quais ela se endereça... não se trata de oferecer um texto acessível, mas de diversificar os modos de integração dos saberes concernentes, como também das denominações utilizadas. Com efeito, 'só são reinvestidas as informações formuladas de maneira compreensível nos sistemas de representação dos destinatários' (Albertini \& Delisle)" (GAUDIN, 1993, p.143). 
De fato, o deslocamento da ênfase da lógica da difusão para a lógica da apropriação, sobrevaloriza a noção de informação face à de documento (e seu conteúdo 'essencial'), como também implica a necessidade de recolocar o problema da categorização enquanto meio de organização: das essências aristotélicas e dos pressupostos baseados no conceito tautológico, passa-se à possibilidade de contemplar a diversidade a partir da referência à função social da informação.

Com efeito, as diferentes formas de presença da enunciação (ou seus distintos graus de intensidade) permitem fundar uma tipologia de informações (numa analogia às propostas da Antropologia Lingüística, evidentemente bastante simplificada e empobrecida)(DUCROT \& TODOROV, 1988, p.291). Quando a informação é um dado, a ênfase está no enunciador - que diz que é assim, incluindo-se o enunciatário modelado à sua imagem. A combinatória (no sentido greimasiano) que caracteriza uma linguagem, aqui, prevê apenas a ativação do que já está dado. Ao considerar a informação como uma construção, deve-se procurar o equilíbrio entre enunciador e enunciatário já que, à combinatória da indexação (contextualizada no documento) deve se somar a combinatória da recepção (contextualizada pela linguagem do usuário). Resulta disso que a construção procede através de hipóteses relativas às várias etapas do processo de tratamento e recuperação da informação, bem como do contexto institucional em que se desenvolve. A construção de uma combinatória não prescinde, portanto, da necessidade de considerar os fluxos dedutivo-indutivos.

Decorre daí, também, a possibilidade de identificação de gêneros de informação diversos segundo a função que exercem, ou seja, informações textuais, informações numéricas etc., em diferentes contextos: informações técnico-científicas para uso acadêmico, para uso propriamente técnico etc.; informações estatísticas enquanto elementos para o planejamento e tomada de decisão; informações sobre serviços públicos enquanto requisito para o exercício da cidadania etc. Em face à cada função definem-se as características da linguagem documentária com o objetivo último de resolver a tensão entre os interlocutores (enunciador e o enunciatário).

Linguagens marcadas preponderantemente pelo enunciador ou trabalham com uma combinatória universal e, fazendo-o, preferem a generalização em detrimento da compreensão (ou intensão), ou são excessivamente herméticas para públicos muito identificados com a instituição. Contrariamente, linguagens marcadas pelo enunciatário apresentam certo grau de independência do enunciador. Segundo nossa proposta, o documento apresenta-se como o contexto a partir do qual, através de operações sucessivas, determinam-se modalidades de informação, devendo-se buscar um modelo intermediário que, através da articulação entre o plano de expressão e o plano do conteúdo, seja possível constituir uma combinatória que combine diversidade de funções e de pontos de vista sobre a informação e a multiplicidade de usuários.

Exemplo de ênfase na combinatória de entrada são os sistemas de classificação bibliográfica já 
referidos. Exemplo de ênfase na combinatória de saída são as search engines, ferramentas de busca disseminadas pela Internet centradas apenas nas estratégias de recuperação que, na ausência de embreantes que permitam realizar a identificação das situações de uso das palavras (ou seus contextos), não funcionam efetivamente na recuperação. São ferramentas exclusivamente sintáticas (os conectores lógicos utilizados não constituem recursos para remeter à mensagem documentária) que não dispõem de mecanismos que permitem realizar a conexão com a combinatória de entrada, onde estão definidas as condições para recuperação da significação, além do fato de serem operadas a partir da palavra que não é veículo do conceito. 


\section{CONCLUSÃO}

\section{Para um conceito contemporâneo de representação documentária: a recuperação do senso comum através da racionalidade}

Nos capítulos precedentes propusemo-nos a analisar contribuições que nos permitissem delimitar um conceito contemporâneo de representação documentária. A busca de parâmetros para tal delimitação resultou, muitas vezes, no registro do processo mesmo de conhecimento, sendo necessário agora sistematizá-lo e sintetizá-lo para precisar o que e como poderemos utilizar tais contribuições para cumprirmos nossa proposta inicial.

Colocamos como objetivo de nosso trabalho analisar a representação documentária a partir de diferentes linguagens documentárias existentes. Pretendíamos verficar o estatuto das linguagens documentárias frente ao desenvolvimento da história das idéias, analisar as possíveis alterações decorrentes da crise paradigmática que atravessa as ciências e avaliar as condições para identificar novos parâmetros teórico-metodológicos para sua construção.

A perseguição desse objetivo levou-nos a empreender uma reflexão para procurar compreender, primeiro, o que significou (ou significa) essa alteração de paradigmas e, segundo, quais os seus reflexos nas atividades documentárias de representação. Nesse processo procuramos verificar como se deu a transformação da concepção de representação na Filosofia e na Lingüística (com uma decorrência da reconstrução da noção de conhecimento), situando parcelas do discurso documentário frente às diversas formas de enfrentar o conhecimento e a representação.

Sob nosso ponto de vista, um dos principais reflexos da alteração paradigmática na Documentação está no deslocamento da ênfase da noção de documento para a de sua função. Essa idéia, assentada no reconhecimento de que os objetivos de transferência da informação contribuem para caracterizar o estatuto mediador das linguagens documentárias, põe em evidência a natureza lingüísticocomunicacional da atividade de representação em Documentação. A compreensão das características e mecanismos das atividades lingüístico-comunicacionais permite verificar que a informação não é um dado objetivo, mas uma construção que resulta de uma hipótese de organização. Para a veiculação das hipóteses acreditávamos no instrumental oferecido pela Terminologia teórica e no papel que os termos, das terminologias concretas, poderiam nos oferecer.

De início, visualizamos os problemas com os quais haveríamos de lidar. Do ponto de vista do enfrentamento dos vocabulários dos domínios aventávamos a hipótese de que a Terminologia clássica, moldada a partir de um modelo racional/cartesiano, poderia não oferecer grandes contribuições frente a domínios em formação ou transformação. De fato, a Terminologia clássica 
postulava a invariância, a univocidade e a construção de definições a partir, principalmente, da lógica formal. Do ponto de vista das linguagens documentárias sabíamos que as normas privilegiavam domínios estáveis e mesmo em relação a eles não apontavam procedimentos claros para o trabalho com a significação.

As hipóteses levantadas - relativamente à restrição ao uso do conceito clássico de definição e à necessidade de integrar a polissemia como fenômeno vocabular para a construção das linguagens documentárias - decorreram da observação das próprias normas (terminológicas e documentárias) ou do que nelas subjaz implicitamente: uma concepção essencialmente assentada em parâmetros racionais e um comprometimento com a teoria da referência a partir do qual seria impossível admitir uma concepção de linguagens documentárias baseada nas características do funcionamento da língua. Nosso problema principal, portanto, era o de encontrar referências que nos pudessem municiar para enfrentar a questão.

As contribuições de Rorty e Boaventura Santos foram fundamentais para situarmos os discursos da Documentação frente aos discursos das ciências. Se por um lado, grande parte destes discursos são identificados como oriundos do senso comum (a despeito de inúmeras reflexões teóricas existentes), por outro, o movimento de desdogmatização das ciências, ao negar o discurso científico como o modo privilegiado do saber, coloca a possibilidade de recuperar os primeiros a partir de uma ótica de racionalidade. Dito de outro modo, a reconstrução deve quase que simultaneamente estabelecer o objeto teórico da Documentação e proceder à sua reconceptualição a partir das experiências dofazer documentário baseadas no senso comum.

Avaliando a questão da representação a partir das contribuições da Filosofia e da Lingüística pudemos verificar que o conceito de representação inerente às linguagens documentárias mais tradicionais combinava pressupostos essencialistas e uma concepção do conhecimento como acúmulo. De modo subjacente, elas preconizavam o conhecimento como dado, restando como tarefa documentária sua reprodução. Mesmo que a noção de transferência estivesse, de algum modo, implícita na tarefa de representar, a ótica a partir do documento não contribuía para fazer prevalecer o fato de que as linguagens documentárias constituem um gênero de metalinguagem particular. As pesquisas que se seguiram aos sistemas de classificação tradicionais voltaram-se, quase que invariavelmente, à procura de categorias gerais de análise que fossem aplicáveis a quaisquer universos a representar. Só mais recentemente passa-se a reconhecer a importância do papel de mediação das linguagens documentárias, sendo imprescindível destacar pelo menos duas linhas principais de abordagem: de um lado, os trabalhos de Gardin - que deram origem à linha de pesquisa Análise Documentária do Depto.de Biblioteconomia e Documentação da ECA-USP que reconhecem a natureza lógico-semântica das operações de representação; num outro extremo, os trabalhos de Blair centralizados nos problemas de recuperação que, diferentemente da primeira, 
considera os problemas de recepção sob a perspectiva da filosofia da linguagem. À exceção de alguns outros trabalhos (nem todos citados nesta pesquisa), raramente se discute a natureza essencial da atividade lingüístico-comunicacional de representação e suas implicações.

Privilegiando a abordagem lingüística saussuriana da representação procuramos estabelecer, conceito a conceito, as analogias com a atividade de representação documentária e a de construção de linguagens de intermediação (admitindo, de fato, que tais atividades situam-se no campo da linguagem), reportando-nos, em vários momentos, a trabalhos da área de Documentação que já destacavam a importância da Lingüística como ferramenta de trabalho. A partir da noção básica de estrutura lingüística, verificamos seu aporte fundamental para o desenvolvimento de metodologias de construção de linguagens documentárias baseadas num sistema de relações. Embora o uso de esquemas de relacionamentos seja prescrito por normas internacionais de elaboração de tesauros, sua base é exclusivamente a da Lógica (tal como nas normas terminológicas na sua versão original), não se mencionando o caráter lingüístico-comunicacional das estruturas elementares de significação, ou só se referindo marginalmente ao fato de que ela se desenvolve como linguagem. Nas normas documentárias a noção de controle pressuposta pelo esquema de relacionamentos não é discutida e definida ou, como não raras vezes acontece, é utilizada apenas a partir dos aspectos que a caracterizam como meio de gerir o empréstimo das designações utilizadas pelas áreas de conhecimento que se quer representar. Através da noção de estrutura lingüística-e das noções decorrentes - procuramos mostrar que o controle extrapola o gerenciamento das formas de expressão e recai sobre os requisitos mínimos para a construção da significação com objetivos de transferência da informação. De fato, o destaque da noção de função do documento sobre a de sua natureza enfatiza a importância do sistema de relações não apenas como esqueleto de sustentação, mas como meio de permitir instaurar a significação a partir da posição relacional de suas unidades.

Como decorrência da noção de estrutura (e face às contribuições que havíamos recolhido da filosofia contemporânea), procuramos confirmar o estatuto de hipótese dos vértices de organização escolhidos para a apresentação das relações nas linguagens documentárias, do que decorre o questionamento de linguagens de intermediação que buscam abarcar todo o conhecimento e que se pretendem permanentes e atemporais.

Advém da noção de estrutura a possibilidade de afirmar que as linguagens documentárias constituem um sistema de significação, já que aliam o recorte operado sobre o conhecimento a uma determinada configuração de relações. Não é possível, porém, afirmar a identidade do signo lingüístico ao signo documentário, uma vez que este último remete à necessidade de regras de uso, além das de construção. A construção do signo documentário solicita a explicitação dos valores paradigmáticos assumidos, contrariamente ao que ocorre com a língua onde eles são armazenados em competência, o que permite afirmar sua condição motivada: os signos documentários significam por força de 
construção. A semiose documentária tem, conseqüentemente, um estatuto particular, já que se pretende que os signos documentários signifiquem de uma determinada maneira. As possibilidades de instaurar verdadeiramente um processo semiótico remetem, também, às restrições que as linguagens construídas apresentam quanto às possibilidades de sintagmatização.

Para melhor operacionalizar a estruturação das linguagens documentárias associamos o conceito de paradigma à noção de categoria da lógica (suspendendo temporariamente a discussão sobre as limitações dessa noção) remetendo às línguas de especialidade a possibilidade de coleta das unidades que deverão compor um sistema de significação. A partir dos conceitos de plano de expressão/ plano de conteúdo de Hjelmslev procuramos mostrar a realidade desses sistemas de significação particulares que articulam, a seu modo, os descritores às hipóteses de organização.

Através do conceito de sincronia procuramos mostrar a possibilidade de analisar as linguagens documentárias enquanto construtos fundados na noção de oposição. Do ponto de vista operacional procuramos mostrar a preponderância do conceito de langue enquanto sistema sobre o de parole, para enfatizar as restrições ao uso da designação de linguagem aos sistemas carentes de um nível primário de articulação.

A análise de algumas das contribuições da pesquisa semântica - particularmente da semânticasemiótica - apontou similaridades entre o trabalho com a significação em universos mais abertos (particularmente literários) e os universos mais restritos como os documentários. A exploração mais profícua dessa vertente exigiria um investimento mais amplo do que aquele previsto nos limites deste trabalho, uma vez que demandaria uma pesquisa prático-operacional. Foi possível compreender, porém, a superioridade de uma teoria diferencial (de base saussuriana) sobre a teoria referencial. De fato, não é possível trabalhar com um conceito de extensão de forma absoluta (como o pretende a Teoria da Referência) frente a universos cujos objetos são relativamente indeterminados. $O$ uso simultâneo de uma semântica-semiótica e de uma Terminologia que admita a linguagem como instância de mediação entre o homem e o mundo permitiria contemplar uma combinatória não autoritária que admite que a construção da significação tem num quadro de referências apenas seu ponto de partida.

A lingüística-semiótica, ou mais precisamente, a semântica-semiótica permite considerar os problemas de comunicação que incluem, necessariamente, componentes pragmáticos. A grande contribuição dessa semântica é a possibilidade de contemplar uma definição que extrapola os limites da definição lógica, uma vez que, ao incluir a noção de interpretante, não restringe o procedimento de sua construção ao inventário das propriedades dos objetos, mas se propõe a considerar os processos que permitem torná-las pertinentes num percurso de semiose. O caráter pragmático desse gênero de definição permite assimilar os condicionantes sociais e institucionais 
envolvidos e entender a informação necessariamente como uma construção.

Já sob o enfoque da tradução, foi possível verificar o estatuto modelizante das linguagens documentárias. Espécie de metalíngua particular, o resultado da transcodificação operada através das linguagens documentárias não está isento de desvios semânticos, razão pela qual as unidades das terminologias poderiam funcionar como interpretantes ou operadores de sentido. As noções de tradução intra-código e entre códigos permite também colocar claramente a distinção entre os resumos e os índices, que instauram, cada um à sua maneira, níveis isotópicos particulares.

Ao abordar as relações lingüísticas pudemos distinguir as relações operadas em nível semântico e as entre formas significantes. A noção de campos associativos confirma a possibilidade de trabalhar a partir da delimitação de zonas de sentido - que podem ser referendadas nas terminologias - nas quais se estruturam relacionalmente as unidades de uma linguagem documentária, incluindo não apenas as relações verticais mas também as horizontais, através da explicitação de mecanismos de abertura semântica ou pressuposição. A identificação dos gêneros de relações lingüísticas permite confirmar que as relações fundantes para a estruturação dos vocabulários são as de oposição e contraste, a partir das quais se definem antônimos, sinônimos, hipônimos e hiperônimos, como também os fenômenos de polissemia, homonímia, monossemia e homossemia. A hipótese inicial que havíamos colocado de que seria necessário considerar a polissemia como fenômeno vocabular para tratar de universos em formação ou transformação ratifica a necessidade de não trabalhar apenas sob o enfoque onomasiológico, já que este pressupõe uma univocidade de interpretação de sentido das unidades vocabulares. É evidente que a tentativa de controlar a polissemia tem como objetivo veicular significados precisos, porém não é possível declinar categoricamente das possibilidades de uso dos termos a partir do reconhecimento de seu núcleo comum. Universos em formação e em transformação fixam apenas gradativamente seus termos, sendo problemático pretender conferir-lhes um significado unívoco. A Socioterminologia, ao considerar o uso efetivo dos termos, reconhece o caráter dinâmico do uso das palavras no discurso.

O grande problema em relação às relações lingüísticas é que elas não contemplam as relações instauráveis na enunciação. Um dos recursos utilizáveis para sistematizá-las nas linguagens documentárias seria o registro das ocorrências de relacionamentos normalmente verificadas nos discursos das áreas, bem como o uso da pressuposição. Sob forma de 'termos relacionados', podese contemplar parte dessas relações que não se constituem em relações do léxico propriamente dito. Fica aberta a questão da sintagmatização, já que ela solicita investimentos que permitam compensar a ausência da primeira articulação característica das línguas naturais. De fato, os mecanismos sintáticos artificiais hoje conhecidos (operadores lógicos e similares utilizados pelos mecanismos de acesso na Internet) não permitem realizar efetivamente articulações semelhantes às existentes nas línguas naturais.

Concebendo a possibilidade de ter, na terminologia concreta dos domínios, os operadores de 
sentido para as linguagens de representação documentária, procuramos sistematizar as contribuições da Terminologia e das normas terminológicas, discutindo seus parâmetros à luz dos princípios de um novo patamar paradigmático. Esse processo nos permitiu confirmar o uso de uma noção de representação muito relacionada à teoria da referência e calcada, particularmente, nos princípios da lógica formal. Com efeito, uma vez que as normas terminológicas foram desenhadas para atender a necessidades de desenvolvimento tecnológico-industrial, não seria de se esperar que elas fossem inteiramente adequadas ao tratamento de universos onde os objetos não são suficientemente determinados.

Foi possível verificar que a ênfase da Terminologia clássica em privilegiar um objeto extralingüístico acaba por não permitir enxergar os condicionamentos decorrentes do caráter lingüísticocomunicacional dos termos. Além disso, a definição terminológica clássica compartilha da idéia de que apenas reconhecemos os atributos das coisas, ignorando o fato de que, antes disso, construímos tais atributos (e a evolução da ciência o confirma) a partir dos quais podemos organizá-los de modo funcional. Ao contrário, uma definição semântico-semiótico-pragmática permite não apenas contemplar o contexto onde o termo se insere, mas suas possibilidades de funcionar como instrumento de conhecimento através de um processo de semiose interpretativa.

Essa concepção está de acordo com aquela que se preocupa em atenuar a rígida separação entre os procedimentos onomasiológicos e semasiológicos, que teria como correspondente uma Terminologia preocupada em relativizar a distinção entre os discursos da ciência e os da linguagem comum. Sob esse prisma, a utilização da distinção entre a palavra e termo, como também a separação entre termos teóricos e técnicos, pretende apenas considerar as determinações que os caracterizam como mais ou menos contextualizados, ou mais ou menos fixados consensualmente. Na realidade, o inventário às vezes intuitivo que precede a construção das unidades de representação das linguagens documentárias mostra um movimento simultâneo do termo para a palavra e da palavra para o termo.

Pudemos confirmar também, a partir das propostas da Socioterminologia, as suspeitas do excesso de racionalidade presente nas normas clássicas da Terminologia tradicional. Para a Socioterminologia, a Terminologia wüsteriana utiliza uma noção de signo lingüístico bastante redutora, não considerando a diversidade das situações comunicativas e os distintos vocabulários envolvidos na tarefa de construção do termo. Reconhecendo a polissemia e a sinonímia, a Socioterminologia prega a assimilação da variação, advogando a prioridade da descrição sobre a prescrição.

Vertentes intermediárias postulam a padronização como meio de melhor viabilizar a comunicação, conferindo à Terminologia tanto a prescrição como a descrição. Uma proposta que declinasse inteiramente de seu papel prescritivo poderia querer supor a possibilidade de um nível ótimo de 
comunicação através de uma língua essencialmente intermediária. O problema, portanto, é encontrar o ponto de equilíbrio e reconhecer o caráter eminentemente mediador que caracteriza as atividades terminológica e documentária.

A partir das contribuições precedentes, procuramos levantar os elementos necessários à construção de um conceito de representação. Em face da ênfase que a Análise Documentária dá aos aspectos metodológicos de construção de representações, a definição de representação correspondente relaciona os processos de condensação de textos aos objetivos de transferência de indicadores de seu conteúdo. Quando aproximamos a representação ao conceito de informação (subjacente na proposta da Análise Documentária), verificamos que ela é distintamente definida tendo como ponto de partida a caracterização do processo de comunicação que envolve emissor e receptor da mensagem (tal como propõe a Teoria da Informação tradicional), centrando-se ora no gerador, ora na mensagem, ora no receptor. Porém, é quando ela privilegia a função básica de transformação de consciências é que fica clara a necessidade de observá-la como uma estrutura de significação que agencia a produção do conhecimento.

A caracterização funcional permite, por sua vez, compreender melhor sua natureza, mostrando a necessidade de explicitar os pressupostos inerentes às representações como meio de promover sua interpretação e apropriação. Essa caracterização permite, também, mostrar os limites das representações na geração de conhecimento, não só em razão de sua condição redutora, como também porque ela depende das condições de sua transferência, quer sob o aspecto do controle institucional (ou das condições de acesso), quer pela marca veiculada pelos próprios sistemas de significação que as caracterizam.

Esse conjunto de características contribui para reforçar o caráter mediador das representações documentárias e mostrar, efetivamente, que se trata de enfrentar um problema de linguagem e entre linguagens.

Pudemos observar também que as representações documentárias podem ser apresentadas sob variados formatos segundo o nível de especificidade de tratamento, mas que sua tipologia não pode ficar adstrita à forma "documento" se se admite um conceito de informação que privilegia sua função. Decorre daí nossa proposta de flexibilizar o conceito de linguagem documentária para contemplar distintos universos informacionais, como também a proposta de sua tipologia a partir da função principal a que se propõem.

Foi possível verificar que, como quaisquer representações, a interpretação das representações documentárias está sujeita a diversos condicionantes, ratificando a necessidade já apontada de fornecer elementos que auxiliem a decodificação do sistema de significação veiculado. 
Do ponto de vista do controle da significação pretendido através das linguagens documentárias vimos que, enquanto sistemas significantes, elas constituem em si mesmas informação. O controle, entendido de uma maneira mais ampla - e não apenas como o produto de relações entre designações de códigos semióticos diferentes - remete à uma rede de relações entre termos através da qual se pretende veicular uma proposta interpretativa. De forma corolária, admitimos que as representações documentárias desencadeiam um processo semiótico particular - um processo de comunicação documentária através do qual se pretende veicular informações com uma margem razoável de precisão interpretativa - mas que esse processo está sujeito, também, a graus de indeterminação decorrentes da impossibilidade de uma comunicação unívoca.

Relativamente aos usuários, procuramos observar que a apropriação das informações depende simultaneamente dos níveis de competência interpretativa e das formas utilizadas para a veiculação de informações. Quanto mais formalizadas são as linguagens documentárias, menor é o grupo de usuários capacitados a compreendê-las e utilizá-las de modo adequado, muito embora uma proposta de atenuamento das fronteiras entre os discursos aponte para a necessidade de uma dissolução entre as distâncias entre essas linguagens.

A representação documentária, para cumprir todos esses objetivos, não pode ficar restrita ao uso de um modelo tradicional de representação. Se o princípio da sistematicidade, operacionalizado através da hierarquia é um dos recursos básicos à dedução (a cadeia), o uso das aproximações não-lineares (a rede) permite explorar melhor a própria relatividade das associações. Uma abordagem não essencialista da representação permite contemplar melhor a diversidade dos universos a representar, a multiplicidade de hipóteses de organização das informações e a heterogeneidade das competências dos usuários.

Sob a ótica da apropriação da informação afirmamos que as linguagens documentárias elaboradas a partir de um lugar fixo de enunciação trazem, de modo subjacente, a crença na informação como um dado, e só podem, conseqüentemente, difundir informação. Apenas as linguagens documentárias que têm como parâmetro o uso equilibrado de referências do enunciador e do enunciatário admitem a informação como construção, aumentando as probabilidades de sua apropriação.

Em resumo, um conceito contemporâneo de representação documentária deve ressaltar a representação como algo que se desenvolve no universo da linguagem e como uma construção que modeliza, a seu modo, a significação, mas cuja apropriação está condicionada ao modo como operacionaliza e veicula tal sistema de significação. Gênero de sistema intermediário de comunicação, as representações através das linguagens documentárias configuram um sistema modelizante secundário que imprime aos universos representados um ponto de vista de organização fundado na presivibilidade de associações e princípios de compartilhamento. 
Se as contribuições da filosofia apontam para uma delimitação de representação documentária como construção (o que permite afirmar que elas se desenham para cumprir determinadas funções), as contribuições da lingüística semiótica, além de afirmar esse caráter, evidenciam o fato de que elas, ao se desenvolverem no universo da linguagem, executam uma determinada capacidade de traduzir, a seu modo, a significação.

Aconstruçãode um conceito contemporâneo de representação requer, portanto, observar as características associadas à língua enquanto estrutura e instrumento de comunicação. O caráter demediação das linguagens documentárias põe em destaque os problemas relativos à comunicação envolvidos na tarefa de representar para transmitir informação. As linguagens documentárias constituem, simultaneamente, a expressão de determinados modos de organização e de forma de comunicação da informação.

Estamos em condições, agora, de sintetizar os requisitos para a formulação de linguagens de representação da informação. É o que se apresenta abaixo: 


\section{LINGUAGEM DOCUMENTÁRIA}

\begin{tabular}{|c|c|}
\hline PRESSUPOSTOS & $\begin{array}{l}\text {. construção lingüístico-semiótica funcional subsidiária de um modo } \\
\text { de conceber a representação e a informação; } \\
\text {. abordagem não essencialista; } \\
\text {. combinação de princípios de sistematicidade e de uso de } \\
\text { aproximações não-lineares; } \\
\text { construção que deve procurar o equilíbrio entre enunciador e } \\
\text { enunciatário; } \\
\text {. abordagem que privilegie, além das relações consensuais entre os } \\
\text { termos, as relações de enunciação no domínio ou área de atividade; } \\
\text {. recuperação do senso comum a partir da racionalidade. }\end{array}$ \\
\hline NATUREZA & $\begin{array}{l}\text {. instrumento de representação documentária; } \\
\text {. sistema de significação de natureza comunicacional; } \\
\text {. metalinguagem documentária; } \\
\text {.combinatória que articula o plano de expressão e o plano do } \\
\text { conteúdo; } \\
\text {. instrumento de mediação entre linguagens; } \\
\text {. linguagem intermediária entre a Linguagem Natural e a Linguagem } \\
\text { Artificial; } \\
\text {. sistema modelizante secundário; } \\
\text {. produto cultural; } \\
\text {. signo motivado; } \\
\text {. signo documentário; } \\
\text {. código construído a partir da segmentação de universos escolhidos } \\
\text { decodificável segundo regras de uso; } \\
\text {. interpretante de um domínio do conhecimento ou área de atividade. }\end{array}$ \\
\hline $\begin{array}{l}\text { FUNÇÃO DA } \\
\text { LINGUAGEM } \\
\text { DOCUMENTÁRIA }\end{array}$ & $\begin{array}{l}\text { promover o controle da significação; } \\
\text {. promover a representação condensada de conteúdos informacionais; } \\
\text {. permitir a transcodificação de conteúdos informacionais ou de } \\
\text { perguntas de usuários; } \\
\text {. promover o acesso e a atualização de informações através da } \\
\text { veiculação de uma proposta interpretativa; } \\
\text {. agenciar a produção do conhecimento. }\end{array}$ \\
\hline
\end{tabular}




\begin{tabular}{|c|c|}
\hline $\begin{array}{l}\text { MODO DE } \\
\text { OPERACIONALIZAÇÃO/ } \\
\text { CONSTRUÇÃO DE } \\
\text { UMA LINGUAGEM } \\
\text { DOCUMENTÁRIA }\end{array}$ & $\begin{array}{l}\text {. elaboração de combinatória (estrutura paradigmática) fundada } \\
\text { num sistema de relações entre termos relativos a um domínio do } \\
\text { conhecimento ou área de atividade; } \\
\text {. explicitação de campos semântico-associativos; } \\
\text {.. definição de vértices (classemas) para fundamentar a estrutura } \\
\text { de significação: } \\
\text {... categorização lógica; } \\
\text {... categorização funcional; } \\
\text {... estabelecimento de relações lógico-semânticas entre os termos } \\
\text { (estruturação de sememas): } \\
\text {... relações de associação hierárquica (quanto à forma de } \\
\text { apresentação) } \\
\text {.... hiperonímia (superordenação), hiponímia (relação genérica e } \\
\text { partitiva; } \\
\text {.... relações de associação não-hierárquica: } \\
\text {.... relações de equivalência: sinonímia, quase-sinonímia, } \\
\text { deslocamento genérico, deslocamento colateral; } \\
\text {.... relações seqüenciais ou espaço-temporais; } \\
\text {.... relações pragmáticas; } \\
\text {... elaboração de definições explícitas ou discursivas; } \\
\text {... elaboração de notas de escopo ou de alcance e de restrições } \\
\text { de aplicação; } \\
\text {... elaboração de regras de uso. }\end{array}$ \\
\hline $\begin{array}{l}\text { ELEMENTOS } \\
\text { ESTRUTURAIS } \\
\text { DESCRITORES }\end{array}$ & $\begin{array}{l}\text {.unidades mínimas de significação; } \\
\text {. unidades preferenciais; } \\
\text {. signos documentários; } \\
\text {. unidades semântico-semióticas } \\
\text {. interpretantes; } \\
\text {. signos motivados; } \\
\text {. unidades de sentido definidas relacionalmente.. }\end{array}$ \\
\hline NÃO-DESCRITORES & $\begin{array}{l}\text {.unidades não-preferenciais; } \\
\text {.unidades de equivalência sinonímica ou quase-sinonímica; } \\
\text {. unidades que pemitem introduzir níveis de redundância necessários } \\
\text { à compreensão. }\end{array}$ \\
\hline DEFINIÇÕES & . Definições semântico-semióticas e pragmáticas dos descritores. \\
\hline NOTAS DE ESCOPO & . Notas explicativas e de alcance de aplicação dos descritores. \\
\hline $\begin{array}{l}\text { ARTICULAÇÃODA } \\
\text { COMBINATÓRIA }\end{array}$ & $\begin{array}{l}\text {. estabelecimento da rede de relações lógico-semântica entre } \\
\text { descritores; } \\
\text { estabelecimento de rede de equivalências sinonímicas e quase- } \\
\text { sinonímicas entre descritores e não descritores. }\end{array}$ \\
\hline REGRAS DE USO & $\begin{array}{l}\text { estabelecimento das regras de uso para a indexação e } \\
\text { recuperação. }\end{array}$ \\
\hline
\end{tabular}




\begin{tabular}{|l|l|}
\hline TIPOLOGIA & $\begin{array}{l}\text {. mais formalizadas X menos formalizadas em face das características } \\
\text { da literatura a representar; } \\
\text {. mais generalizantes, menos generalizantes em face dos usuários- } \\
\text { alvo. }\end{array}$ \\
\hline REFERÊNCIA & $\begin{array}{l}\text {. abordagem terminológica que considere a natureza lingüístico- } \\
\text { comunicacional da atividade de representação; } \\
\text {.abordagem terminológica que equilibre prescrição e descrição; } \\
\text {. abordagem terminológica que considere o uso efetivo dos termos; } \\
\text {.terminologia dos domínios de conhecimento e áreas de atividade } \\
\text { (operadores de sentido; interpretantes); } \\
\text {. análise lógico-semântica (restrição: o uso da lógica formal é apenas } \\
\text { adequada a linguagens altamente formalizadas, não sendo útil frente } \\
\text { a universos caracterizados pela equivocidade, polissemia etc.); } \\
\text {.normas terminológicas e normas documentárias revistas à luz dos } \\
\text { parâmetros lingüístico-semióticos e dos parâmetros que postulam } \\
\text { a revisão do cientificismo. }\end{array}$ \\
\hline LIMITES E & $\begin{array}{l}\text { RESTRIÇÕES } \\
\text {.redução semântica; } \\
\text {. semiose controlada; } \\
\text {.possibilidades de sintagmatização pobre (requer investimentos). }\end{array}$ \\
\hline
\end{tabular}




\section{ANEXO}

\section{A representação de informações públicas institucionais em sistemas informatizados: exemplos para a análise}

Os exemplos aqui apresentados devem ser vistos apenas como uma ilustração de nosso trabalho, já que não colocamos como objetivo a construção de uma linguagem documentária concreta. Ao relacioná-los pretendemos tão somente salientar aspectos inerentes à construção de linguagens de representação onde a questão da intermediação está mais evidente - o usuário da informação pública institucional é bastante diferente daquele das informações acadêmicas em função das quais os modelos de representação documentária têm sido construídos - e onde tornam-se mais explícitos os problemas relacionados ao deslocamento da prioridade do documento para a sua função.

É preciso dizer, todavia, que os exemplos aqui apresentados constituem apenas uma parte das linguagens de representação elaboradas nas instituições, não sendo possível afirmar que, no seu todo, elas possam ser efetivamente designadas como linguagens documentárias no sentido que propusemos anteriormente, já que requerem, ainda, maiores investimentos para se caracterizarem comotal.

Os três exemplos referem-se à informação pública institucional. O primeiro, trata da representação de informações estatísticas; o segundo, de informações para o cidadão de um modo geral; o terceiro, constitui um sistema de metainformação, ou seja, remete a diferentes sistemas de informação de diversas naturezas existentes na administração pública do Estado de São Paulo. Além dos condicionantes relacionados às características da informação pública institucional, na sua construção procuramos reconhecer:

a) a natureza comunicacional da atividade de representação e a correspondente necessidade de construir uma combinatória;

b) um conceito de informação como construção;

c) a necessidade de utilizar princípios de racionalidade aliados aos do senso comum;

d) os condicionantes e restrições da exploração dos recursos das novas tecnologias.

O exame do processo de representação de informações públicas institucionais permite verificar, concretamente, os limites implicados na utilização de um conceito de informação como dado e, conseqüentemente, os problemas decorrentes do uso de uma combinatória universal como parâmetro de indexação. Permite, também, mostrar as restrições do uso de uma "linguagem documentária" conforme sua designação tradicional. Os dois problemas se relacionam e se implicam mutuamente. 
É inegável que a delimitação do conceito mais formalizado de linguagem documentária permitiu imprimir maior rigor à área de representação (só passando pelo discurso normal é que poderemos pretender o discurso anormal), porém essa designação ainda mantém as marcas da reificação da noção de documento - as terminologias trazem, consigo, os parâmetros a partir dos quais foram cunhados os termos. Por outro lado, a centralidade das preocupações com a busca e o uso de categorias universais não se mostra operacionalizável quando se deseja colocar em foco a função da informação.

A noção de documento marcou muito a prática documentária, porém não é exclusiva da Documentação. De fato, a circulação das informações públicas institucionais esteve, durante muito tempo, restrita às unidades de produção. As informações eram tratadas de modo burocrático (lembre-se de "Todos os Nomes”, de Saramago, onde a separação dos registros era feita exclusivamente a partir da dicotomia vivos X mortos), seja porque as instituições não visualizavam claramente seu papel social, seja porque se perdiam nos meandros formais da documentação. É apenas no momento em que a informação passa a preponderar sobre o registro - enquanto meio de promover a construção social do sentido e recurso para a modificação das relações entre os indivíduos e a sociedade - que se torna evidente a necessidade de promover sua organização para transferência.

As instituições públicas só muito recentemente têm assumido a importância do tratamento para a disseminação de informações. Esse reconhecimento ficou mais evidente a partir do uso dos novos recursos tecnológicos e, particularmente, da Internet, que embora seja apenas um canal, tem exercido, nas instituições públicas, o papel de 'catalisadora' dos avanços da informática. Novo meio de veiculação de informações, a Internet caracteriza-se pelas suas especificidades, porém, como qualquer meio, requer a utilização de um código particular para a realização dos processos de comunicação.

Por si só a Internet não constitui efetivamente um código e a transferência da informação é, de fato, um problema específico de linguagem. À combinatória de entrada dos dados deve estar associada uma combinatória de saída. A especificidade da Internet (e dos meios informatizados) traduz-se no aumento das possibilidades de recuperação física de informações em razão, particularmente, do uso de recursos hipertextuais. Tais possibilidades se dissolvem, porém, caso os objetivos de transferência não estejam associados aos de organização e recuperação. Existe, portanto, uma função de pressuposição recíproca, a par das suas diferenças, entre as estratégias da combinatória de entrada e da combinatória da saída.

Por outro lado, é preciso considerar que a Internet instaura um usuário relativamente indeterminado. Se sua presença física nas instituições permitiria trabalhar diretamente a 
negociação de sentido, sua ausência concreta e presença virtual solicita a utilização de mecanismos mais amplos de disseminação de informações. Além disso, a despeito de que a língua é uma forma de atividade cooperativa (PUTNAM, 1990 apud GAUDIN, 1993, p.191), os modos de apropriação não são homogêneos, como não são homogêneas as formas de designação das informações. Observa-se que quanto mais a informação destina-se a um público amplo, mais a combinatória tende a reproduzir a oralidade. A tendência universalizante das linguagens documentárias tradicionais não possibilitaria sequer pensar nessa possibilidade, já que, quanto mais universal, menor é a compreensão.

No contexto de alterações políticas, sociais e econômicas, o trabalho a partir de um novo conceito de informação, aliado às possibilidades (e questões) colocadas pelas novas tecnologias, permite afirmar a impossibilidade de enfrentar a questão da representação (em quaisquer universos que sejam) a partir de um modelo exclusivamente baseado na racionalidade. 


\section{EXEMPLO 1: A representação de informações estatísticas - São Paulo em Dados}

Embora as instituições confiram vários arranjos para os seus dados estatísticos, ainda não se reconhece suficientemente que eles têm que ser expressos como linguagem para que possam ser efetivamente inseridos em processos comunicacionais. Proposta inusitada num campo que tradicionalmente só reconhece conteúdos de natureza textual (ou mais propriamente, escritos), a elaboração de uma linguagem documentária para a representação de informação estatística permite levantar concretamente alguns dos problemas decorrentes de uma alteração fundamental de concepção de organização e tratamento da informação. A transferência de informação estatística requer a construção de uma combinatória que privilegie, mais que sua natureza, sua função, ou seja, funcionar como instrumento de planejamento e recurso para a tomada de decisão.

O caso ora apresentado refere-se a uma experiência em desenvolvimento na Fundação Sistema Estadual de Análise de Dados - SEADE ${ }^{26}$. Herdeira do antigo Departamento de Estatística do Estado de São Paulo, a instituição é responsável pela sistematização de informações estatísticas sócio-econômicas produzidas por várias fontes estaduais e pela coleta direta de dados do movimento do registro civil (nascimentos, óbitos, casamentos), das Finanças Públicas Municipais, da situação de Emprego e Desemprego na Grande São Paulo (Pesquisa realizada em conjunto com o DIEESE - Departamento Intersindical de Estatísticas Sócio-Econômicas), das Condições de Vida da População etc. As publicações sistematicamente editadas (em papel ou em meios eletrônicos) constituem apenas uma pequena parcela do conjunto de informações produzidas.

A necessidade de desenvolver uma linguagem para representação desse gênero de informações ficou mais explícita, no caso da Fundação SEADE, quando da veiculação de seus dados na Internet, quando se percebeu que o uso de ferramentas do tipo search engines não apresentava resultados satisfatórios.

Uma linguagem para o tratamento e representação de informações estatísticas tem suas especificidades relativamente às linguagens construídas para a representação de textos. Não há metodologias sobre a representação desse gênero de informação e os bancos de dados similares não dispõem, além do próprio arranjo, de mecanismos ágeis de busca e recuperação. As metodologias para o desenvolvimento de linguagens documentárias que têm por objeto textos não contemplam aspectos particulares à representação de dados estatísticos. Por exemplo, um texto sobre "frutas “ pode ser indexado sob "frutas". Já uma tabela pode ter na sua denominação geral o termo "frutas", porém apresentar dados estatísticos relativos a abacaxi, abacate, laranja,

26 Participamos do projeto enquanto consultora. 
maracujá etc. Não pode, portanto, ser indexada sob o termo "frutas", o que remeteria apenas a tabelas cujo conteúdo seria uma totalização.

A dificuldade de tratamento dos dados estatísticos - que, a seu modo, poderiam ser classificados como um gênero de discurso realizado a partir de mensurações determinadas é que eles constituem uma manifestação evidente de recortes sucessivos, devendo-se decidir qual é o nível de recorte a ser trabalhado (opção ou ponto de partida da análise). Dito de outro modo, um dado estatístico pode ser apresentado sob forma de dados primários resultantes de uma coleta original, e dados secundários, resultantes de processamento e sistematização. Dados primários não são normalmente disponibilizados pois constituem informações muitas vezes confidenciais. A divulgação de dados primários permite, na maior parte das vezes, a identificação de informantes, ferindo os princípios de sigilo. Os dados secundários, por sua vez, são caracterizados por níveis de ordenação. "Primeiramente, a enumeração cria um 'vínculo de uniformidade' em torno dos objetos contados - pode-se adicionar laranjas e maçãs quando se desejar saber a quantidade de frutas. Em segundo lugar, os números possibilitam que ordens de magnitude diferentes possam se relacionar entre si - as distâncias marítimas em relação a altitudes terrestres, o volume de um barril de cerveja em comparação com o tubo de banha de porco, o clima de Massachussetts e o de Londres. Em terceiro, os números podem separar os efeitos combinados de vários componentes e, assim, estabilizar um processo que esteja em andamento; a velocidade pode ser decomposta em tempo e espaço, o crescimento da população em fertilidade e mortalidade. E o número pode ser utilizado em termos de probabilidade para se ter a noção de risco" (COHEN apud SENRA, 1998).

A lógica que preside as observações condiciona a representação estatística. Lugar e modo de observação determinam o valor da informação resultante. Os vínculos estabelecidos entre os dados promovem ordenações a partir de critérios adotados pelo observador, privilegiando pontos de vista determinados. Assim sendo, ao juntar dados estatísticos para compor tabelas, fixam-se novas relações entre dados, que se sobrepõem, por sua vez, à determinação anterior. O tratamento de dados secundários evidencia, conseqüentemente, vários níveis de ordenação.

Ao criar uma linguagem controlada e relativamente padronizada para a entrada de dados e para sua recuperação enfrenta-se, pois, a necessidade de identificar um nível de ordenação a partir do qual o usuário possa estabelecer um maior número de correlações (a informação é uma construção). Enquanto instrumento de mediação, a função de uma combinatória é, antes, mostrar como pode ser organizada a informação, mais do que dizer o que ela significa. A fundamentação da proposta é que as tabelas estatísticas consubstancializadas nos produtos formais de uma instituição - as publicações em meio impresso ou eletrônico - já respondem 
pelas abordagens privilegiadas pela instituição. Ao disponibilizá-las a instituição torna explícito o modo como concebe a informação. Ao promover também a disponibilização de dados pontuais, cujo nível de ordenação se desenha em função da reutilização, cria-se a oportunidade para que o usuário construa, ele mesmo, um nova ordenação e, conseqüentemente, uma nova informação. Ao mesmo tempo, pressupõe-se que a constituição de bancos de dados deve partir de níveis mais desagregados de informação, como meio de controle e integridade dos dados originais, o que não significa necessariamente postular que o nível mais desagregado seja o elemento primitivo para a ordenação. Essa hipótese legitima-se a partir da verificação que um mesmo dado é passível de ser reorganizado de distintas maneiras, conforme a função de referência, proposta distinta daquela que procura exclusivamente nas categorias gerais o parâmetro de observação.

A consecução de objetivos de uma disseminação mais ampla requer uma estrutura (ou uma combinatória de entrada) que privilegie o tratamento individual de itens de dados, considerando-se 'item de dado' um dado em baixo nível de agregação. Obviamente, isso já representa um modo de ordenação (uma escolha estratégica do escalão de profundidade a ser dado à descrição), porém é impossível organizar para disseminar na ausência de um princípio de sistematização. A construção desse princípio é tarefa institucional, devendo combinar utilidade (do ponto de vista do enunciador e do enunciatário - esta última identificada a partir das formas de demanda) e consenso prático-institucional nos modos de agregação (reconhecimento de agregações do enunciador e dos enunciatários).

É inevitável definir uma grade classificatória para organizar os dados, porém ela deve ser concebida antes como o suporte estrutural (para articular os planos de expressão e de conteúdo), já que deve relativizar-se a partir da possibilidade de relacionamentos horizontais (a estrutura vertical constitui o eixo paradigmático da linguagem; as relações horizontais, as possibilidades de combinação).

A grade classificatória parte da delimitação de grandes categorias de dados e de definições, sendo estas últimas mais formalizadas, em alguns casos, e menos formalizadas, em outros, variando conforme a própria condição de estabilidade conceitual de cada subdomínio em particular. Um mesmo item de dado, sempre que necessário (face à demanda) pode ser classificado sob mais de uma categoria (ou a ela se vincular através do registro de associações mais comuns). A categorização não pode, entretanto, ser um empecilho ao acesso à informação. A vantagem da divulgação de informações na Internet está na possibilidade de revisões contínuas, procedendo-se a adequações tantas vezes quanto necessário em face às observações feitas pelos usuários. 
Relacionamos abaixo os temas que constituem os vértices das hierarquias utilizadas:

\begin{tabular}{|l|}
\hline Agropecuária \\
Caracterização do Território \\
Comércio \\
Comunicação \\
Cultura \\
Demografia \\
Eleições \\
Energia \\
Finanças Públicas Municipais \\
Finanças Públicas Estaduais \\
Finanças Públicas Federais \\
Habitação \\
Indústria \\
Justiça e Segurança \\
Política Urbana \\
Rendimento \\
Saúde \\
Serviços \\
Sistema Financeiro \\
Trabalho \\
Valor Adicionado Fiscal \\
\hline
\end{tabular}

A estruturação de uma linguagem do gênero deve permitir a possibilidade de diversos modos de visualização ${ }^{27}$. Mais do que hierarquias fixas, o modelo procura privilegiar as redes semânticas, de forma a permitir oferecer opções por buscas dedutivas (a partir de Temas que se subdividem) ou por termos e palavras (diferente de busca por palavra das search engines já que pressupõe sua organização anterior).

No exemplo a seguir, reproduzimos apenas o lay-out que orientou a construção da hierarquia de Demografia* da página São Paulo em Dados na Internet. Mais à frente reproduzimos exemplo do banco de dados da linguagem estruturada, onde está presente a rede de relações utilizada.

27 Para visualizar a página correspondente (ainda não disponível com todos os recursos previstos), consultar:http://seade.gov.br/cgi-bin/lingov98/spd.ksh, ou escolher o produto São Paulo em Dados na página seade.gov.br. Para reprodução parcial, consultar arquivo spd.doc (MSWord) no disquete anexo.

* Para consultar este exemplo de forma dinâmica, consultar arquivo dem.doc (MSWord) no disquete anexo. 
$1^{\circ}$ nível do Tema Demografia:

DEMOGRAFIA

Casamentos?

$\underline{\text { Óbitos }}$

Evasão de óbitos ?

Nascidos Vivos ?

População

Taxas

$2^{\circ}$. nível do Tema Demografia, item Óbitos:

ÓBITOS

Gerais

$\underline{\text { Infantis }}$

Mulheres em idade fértil

Perinatais

Nascidos mortos

$3^{\circ}$. nível do Tema Demografia, item Óbitos/

Infantis:

[ÓBITOS] INFANTIS

Neonatais

Neonatais precoces

$?$

Pós neonatais

$4^{0}$. nível do Tema Demografia, item Óbitos/

Infantis/Neonatais:

[ÓBITOS] INFANTIS / Neonatais

$\underline{\text { Taxa de mortalidade neonatal }}$ 


\section{$5^{\circ}$. nível do Tema Demografia, item Óbitos/Infantis/ Neonatais/Total}

A partir da última seleção realizada (Taxa), os dados pertinentes.

(ver http://seade.gov.br/cgi-bin/lingov98/spd.ksh)

OBS.: às interrogações correspondem definições.

A observação do exemplo acima permite evidenciar o modo de construção da combinatória, uma vez que se utiliza princípios de organização hierárquica simultaneamente a critérios funcionais. De fato, a estrutura adotada não representa uma hierarquia no seu sentido lógico. Veja-se a primeira série da árvore Demografia - Casamentos, Óbitos, Evasão de óbitos, Nascidos vivos, População, Taxas - onde se procurou ressaltar as diferenças entre os eventos demográficos: Evasão de óbitos é um evento que poderia estar subordinado à Óbitos, porém tem uma importância destacada para uso de especialistas em Demografia e Saúde. População poderia ser um termo superior a englobar todos os outros, porém preferiu-se utilizar o nome da disciplina-Demografia - que se preocupa com a mensuração dos eventos, até porque a maior parte dos dados relaciona-se, de algum modo, à População. Sob população ficam apenas os dados diretamente relacionados à mensuração censitária ou a projeções. A entrada 'Taxas' constituiu um recurso para abreviar a pesquisa, considerada a freqüência da demanda. Para evitar perda de informação as taxas são indexadas sob "Taxas", mas também sob o evento considerado. Ex.: Taxa de mortalidade infantil aparece, também, sob Óbitos/ Infantis, porque é um dado de óbito que não está apresentado em termos absolutos.

Na realidade, a definição das subcategorias é, muitas vezes, mais funcional do que lógica. Veja-se por exemplo, o caso do tema Saúde:

\section{$1^{\circ}$. nível do Tema Saúde:}

\section{SAÚDE}

$\underline{\text { Recursos físicos }}$

Doenças de notificação compulsória

Atendimentos

Recursos humanos 


\section{$2^{\circ}$. nível do Tema Saúde relativo a Recursos Humanos:}

Profissionais de Saúde

Horas disponíveis para atendimento

Pode-se verificar no exemplo que o critério adotado foi eminentemente pragmático, já que os dados disponíveis não justificavam a existência de níveis intermediários de relacionamento. Essa situação se modifica, naturalmente, com a inclusão de novas séries de informação.

Requisitos funcionais sobrepõem-se aos lógicos quando se utiliza ou abreviação hierárquica ou quebra de princípios de seriação para dar conta de necessidades pragmáticas. Não se trata de desprezar o princípio das conjunções e disjunções. Ao contrário, procura-se aqui integrar contribuições que ampliam a noção de campo semântico através do registro de modos consensuais de enunciação (descrição a partir das palavras-tipo e das palavras-evento, mais as combinações advindas da abertura semântica).

A veiculação de uma combinatória de representação de informações solicita, também, a explicitação dos pontos de partida utilizados como meio para viabilizar uma negociação de sentido. No exemplo precedente - lay out da hierarquia de Demografia -, à interrogação deve corresponder, na versão para a Internet, uma definição, conforme se segue (ver também arquivo Dem.doc, em disquete): 


\section{Exemplo de definição:}

\section{TAXA DE MORTALIDADE NEONATAL (0 A 27 DIAS)}

Relação entre os óbitos infantis do período neonatal, ou seja, durante as primeiras 4 semanas de vida ou até 27 dias completos, ocorridos e registrados numa determinada unidade geográfica e período de tempo (em geral, um ano) e os nascidos vivos no mesmo período, segundo a fórmula:

óbitos infantis de 0 a 27 dias ocorridos no período

nascidos vivos no período

OBS.:

1. Segundo algumas metodologias estatísticas o período neonatal se estende até o $1^{\circ}$. mês de vida.

FONTE: Base de dados terminológicos - Fundação SEADE

De fato, uma proposta que se preocupe em criar condições para a apropriação das informações requer a veiculação das definições utilizadas. As instituições, entretanto, nem sempre dispõem de definições de seus dados ou, muitas vezes, carecem de parâmetros homogêneos para sua apresentação. Por esse motivo (além do fato de que a construção de hierarquias também disso depende), a construção de combinatórias muitas vezes desencadeia processos de coleta terminológica para identificar as variações de designação muitas vezes no interior da própria instituição. Esse processo requer a adoção de fichas de coleta terminológica como meio de garantir rigor de registro e requisito para a constituição de bancos de referência para a construção de definições. 
MODELO de FICHA DE COLETA DE DEFINIÇÕES

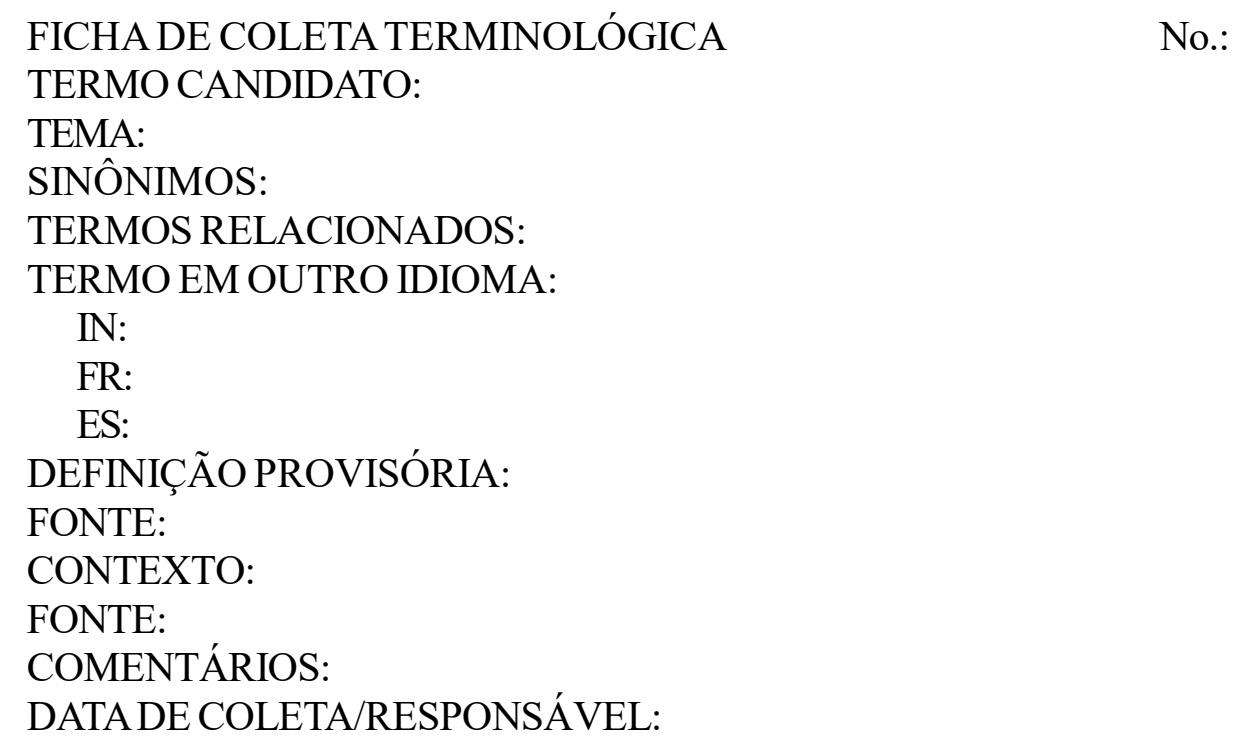

$\mathrm{IN}$ :

FR:

ES:

DEFINIÇÃO PROVISÓRIA:

FONTE:

CONTEXTO:

FONTE:

COMENTÁRIOS:

DATADE COLETA/RESPONSÁVEL:

No.:

EXEMPLOS DE FICHAS PREENCHIDAS para o termo "Evasão de óbitos":

FICHA DE COLETA TERMINOLÓGICA

TERMO CANDIDATO: Evasão de óbitos

TEMA: DEMOGRAFIA

DEFINIÇÃO PROVISÓRIA: Óbitos de residentes ocorridos em outras localidades

FONTE: Perfil Municipal de Saúde

DATA DE COLETA/RESPONSÁVEL: 25/04/97 Jussara

FICHA DE COLETA TERMINOLÓGICA

TERMO CANDIDATO: Evasão de óbitos/Invasão de óbitos

TEMA: DEMOGRAFIA

DEFINIÇÃO PROVISÓRIA: Evasão de um evento: variável que identifica ocorrências (do evento) fora de uma determinada unidade geográfica, envolvendo indivíduos residentes nessa unidade. Invasão ...: variável que identifica ocorrências (do evento) em determinada unidade geográfica envolvendo indivíduos residentes fora dessa unidade.

FONTE: Projeto Arquivo Demográfico

DATA DE COLETA/RESPONSÁVEL: 25/04/97 Marilda 


\section{FICHA DE COLETA TERMINOLÓGICA}

No.:37

TERMO CANDIDATO: Evasão de óbitos/Invasão de óbitos

\section{TEMA: DEMOGRAFIA}

CONTEXTO: ... tem existido sempre o problema de invasão e/ou evasão dos eventos que se caracterizam pelas ocorrências fora de seu município de residência (p. 4).

"Quando um evento relativo a uma pessoa residente em determinada localidade " $A$ " ocorre em "B" dizemos que em " $A$ " houve a evasão de um nascimento ou óbito e que em "B" ocorreu uma invasão" (p. 4). "Vários são os motivos que podem levar uma pessoa a morrer fora de sua região. Entre estes o que denomina-se motivos intencionais, que são aqueles em que as pessoas foram buscar tratamento médico, e os casuais, os provocados por acidentes, homicídios, suicídios ou, então, por morte repentina ... As próprias condições geográficas podem ter uma grande influência nessa evasão ... “( (p. 5)

FONTE: Informe Demográfico, n.12, p., 1984.

DATA DE COLETA/RESPONSÁVEL: 11/05/97 Marilda

FICHA DE COLETA TERMINOLÓGICA

TERMO CANDIDATO: Taxa de evasão de óbitos / Taxa de invasão de óbitos

\section{DEFINIÇÃO PROVISÓRIA:}

Taxa de evasão = óbitos de residentes que ocorreram em outra área

Total de óbitos por residência na área

FONTE: Informe Demográfico no. 7, p.168, 1982.

Data de coleta/Responsável: Marilda 15/04/97

FICHA DE COLETA TERMINOLÓGICA

TERMO CANDIDATO: Taxa de evasão de óbitos/Taxa de invasão de óbitos

TEMA: Demografia

DEFINIÇÃO PROVISÓRIA:

Taxa de evasão $=\underline{\text { óbitos de residentes ocorridos em outras localidades }}$ X 100 total de óbitos de residentes

Taxa de invasão $=\underline{\text { óbitos de não-residentes ocorridos na localidade }}$ X 100 total de óbitos ocorridos nessa localidade

FONTE: Informe Demográfico, n. 12, p.5, 1984.

CONTEXTO: ... motivos sócio-econômicos ... dificultam ou impedem ... dificuldades de locomoção e transporte [podem] impedir uma maior busca de recursos médico-hospitalares, gerando ... baixa taxa de invasão (p.16).

COMENTÁRIO: A taxa de evasão de óbitos é, geralmente, um indicador das disponibilidades de recursos médico-hospitalares.

DATA DE COLETA/RESPONSÁVEL: 10/05/97 Marilda 
FICHA DE COLETA TERMINOLÓGICA

TERMO CANDIDATO: Taxa de evasão de de óbitos

TEMA: DEMOGRAFIA

DEFINIÇÃO PROVISÓRIA: Óbitos de residentes ocorridos em outras localidades, divididos pelo total de óbitos de residentes (por 100).

FONTE: Perfil Municipal de Saúde

DATA DE COLETA/RESPONSÁVEL: 25/04/97 Jussara

A partir das fichas de coleta e da análise das definições ou dos contextos onde se inserem os termos, elabora-se uma proposta de definição que se submete à discussão.

\section{FICHA DE PROPOSTA DE DEFINIÇÃO}

$\mathbf{N}^{\mathbf{0}}: 17$

TERMO: Taxa de evasão de óbitos/Taxa de invasão de óbitos

\section{SINÔNIMOS:}

TERMO EM OUTRO IDIOMA: Verificar porque o termo não aparece em outras línguas: títulos consultados: Thesaurus Popin; Guía rápida de Población; Diccionario Demográfico Multilingüe.

OBS.: Segundo a equipe do DOCDOP- Sistema de Documentação Bibliográfica em População, o termo é substituído, em outras línguas, por Queda de Mortalidade.

\section{FONTES UTILIZADAS PARA CONSTRUÇÃO DA DEFINIÇÃO:}

1) PERFILMUNICIPALSAÚDE; 2) INFORME DEMOGRÁFICO no. 12;3) INFORMEDEMOGRÁFICOn. 7

PROPOSTA DE DEFINIÇÃO: Taxa de evasão de óbitos é a taxa que identifica a relação entre os óbitos de residentes de uma localidade geográfica ocorridas fora dessa localidade, pelo total de óbitos residentes, segundo a fórmula:

Taxa de evasão $=$ óbitos de residentes ocorridos em outras localidades $X 100$

total de óbitos de residentes

A taxa de evasão de óbitos é um indicador geralmente utilizado para verificar a disponibilidade de recursos médico-hospitalares do município de residência dos indivíduos e a atração exercida por outros municípios onde tais recursos são melhores e/ou mais especializados. A existência de recursos médico-hospitalares não é, entretanto, o único fator a influenciar essa taxa, sendo também necessário considerar fatores sócio-econômicos, facilidades de locomoção e transporte, condições geográficas, motivos intencionais (busca voluntária de tratamento médico em outro município), motivos casuais (acidentes, homicídios, suicídios ou morte repentina, etc). Municípios que possuem hospitais universitários constituem, geralmente, pólos de atração regionais.

... (Completar - taxa de invasão)

Taxa de invasão $=$ óbitos de não-residentes ocorridos na localidade $X 100$

$$
\text { total de óbitos ocorridos nessa localidade }
$$

OBS.:

1. Normalizar: localidade geográfica/município/unidade geográfica.

2. Verificar necessidade de incluir último parágrafo, uma vez que a definição de taxa de evasão/invasão contempla essas observações.

3. Discutir com o técnico, pertinência de apresentar as definições complementares em separado. Opções: a) definição sobre evasão/invasão (termos opostos, reunidos numa só entrada), seguido da definição de taxa de evasão/invasão; b) definições separadas sobre evasão/invasão e taxa de evasão/invasão, ligadas por remissivas ver também.

RESPONSÁVEL: Marilda

DATA: $11 / 05 / 97$ 
Observe-se que em alguns casos - como os citados acima - os termos são coletados não de forma isolada, mas a partir da oposição que os define. Isto permite garantir, além de economia no sistema, a apreensão da complementaridade que condiciona uma definição.

A versão final da definição, depois de submetida à aprovação de especialistas, passa a integrar o banco terminológico propriamente dito.

\section{FICHA TERMINOLÓGICA}

TERMO: Evasão de óbitos/Invasão de óbitos

\section{SINÔNIMOS:}

TERMO EM OUTRO IDIOMA: Obs.: não há designação correspondente em outro idioma muito embora a variável possa ser calculada.

DEFINIÇÃO: Evasão e invasão de óbitos são variáveis opostas que se caracterizam pela ocorrência de óbitos fora da área geográfica de residência dos indivíduos. "Quando o evento relativo a uma pessoa residente em determinada localidade " $A$ " ocorre em " $B$ " dizemos que em "A" houve a evasão ... e que em "B" ocorreu uma invasão"(CAMARGO, A.B.M. Os fenômenos da invasão e evasão de óbitos em São Paulo, 1977/80). Informe Demográfico, n. 12, p.4, 1984).

A evasão de óbitos, portanto, identifica a ocorrência de mortes de residentes de uma unidade geográfica fora dessa unidade. Contrariamente, a invasão de óbitos identifica a ocorrência de mortes em uma unidade geográfica envolvendo indivíduos residentes fora dessa unidade.

OBS. 1: O fenômeno da evasão/invasão de óbitos se deve a várias causas: procura de tratamento médico fora do município de residência, acidentes, homicídios ou morte repentina fora do local de residência etc. Altas taxas de evasão de óbitos indicam, geralmente, ausência de recursos médico-hospitalares na área geográfica de residência dos indivíduos. Inversamente, localidades que contam com maiores condições de atendimento médico-hospitalar, podem apresentar taxas mais elevadas de invasão de óbitos (CAMARGO, A.B.M. Os fenômenos da invasão e evasão de óbitos em São Paulo (1977/80). Informe Demográfico, n. 12, p.4, 1984).

OBS. 2: O termo foi provavelmente cunhado na literatura brasileira para se enfatizar o registro da mortalidade por ocorrência. Para recuperação da gênese do termo consultar:

BERQUÓ, E. \& GONÇALVES, M.A.I. A invasão e óbitos no município de São Paulo. Cadernos Cebrap, n.19, 1974.

BARBOSA, V. Mortalidade "de fato" e de "direito" pelas divisões político-administrativas do Município de São Paulo no quinqüênio 1959-1963: algumas considerações de interesse epidemiológico e administrativo. Revista de Saúde Pública, v.3, n.1,pp.67-77, 1969.

FRIAS, L.A.M. Tábuas de mortalidade de alguns municípios e a influência sobre as mesmas dos óbitos de não residentes registrados nessas capitais. Revista Brasileira de Estatística, v.35, n.137, p. 35-55,jan./mar.1974.

RESPONSÁVEIS: Silvia G. Rocha; Marangone; Rute Godinho; Marilda L.G. de Lara Data das discussões: $11 / 05 / 97 ; 28 / 08 / 97 ; 30 / 09 / 97$.

Revisão final: 26/11/97 
Verificou-se concretamente, que as definições não podem ser elaboradas apenas a partir do modelo "aristotélico". Veja-se abaixo como uma definição pode contemplar as variações de interpretação conceitual:

\section{POPULAÇÃO URBANA / POPULAÇÃO RURAL}

1. As categorias rural e urbana de uma unidade geográfica são, no Brasil, definidas por lei municipal. Os critérios para determinar se um domicílio fica na zona rural ou urbana são políticos e variam, portanto, de um município a outro.

2. Em relação aos domicílios, o IBGE, órgão responsável pelo Censo Demográfico, identifica duas situações: em "situação urbana" estão os domicílios que se localizam em áreas urbanizadas ou não, correspondentes às Cidades (Sedes Municipais), às Vilas (Sedes Distritais) ou às Áreas urbanas Isoladas; em "situação rural" estão os domicílios que se localizam fora dos limites acima definidos, inclusive os Aglomerados Rurais de Extensão Urbana, os Povoados e os Núcleos.

As definições de Cidade, Vila, Área urbana Isolada, Aglomerado Rural de Extensão Urbana, Povoado e Núcleo são, em primeiro lugar, legais, seguidas de características relacionadas à presença ou não de construções, arruamentos, edificações e ocupação urbana. Uma vez que o critério para definir se uma área é urbana ou rural é eminentemente legal (conforme as Leis Municipais de Zoneamento), a interpretação das taxas de urbanização só poderá ser feita nos limites dessa definição (IBGE. Sinopse Preliminar do Censo Demográfico, 1991).

A veiculação de definições pode, em certos casos, contemplar concepções conflitantes. Este não foi o caso das definições acima expostas, porém sabe-se de antemão que o tratamento das informações de Emprego irá esbarrar nesse problema. A concepção de emprego e desemprego utilizada pela Fundação SEADE é diferente daquela adotada pelo IBGE. Ao incluir informações relativas à pesquisa feita pelo SEADE/DIEESE, a definição dos termos necessariamente deverá remeter às diferenças metodológicas entre as pesquisas, visando alertar o usuário sobre condicionantes e implicações da definição.

Além das definições, é necessário que a estrutura hierárquico-relacional seja complementada com o registro das equivalências (variantes de designação ou sinônimos), correspondências em outras línguas (inglês e espanhol ${ }^{28}$ ) e, principalmente, com uma rede de relações associativas não-hierárquicas

$28 \mathrm{O}$ acesso às páginas em inglês e espanhol não foi, ainda, realizada a partir de critérios terminológicos. 
registradas como informação complementar. Esse conjunto de relações é requisito para desenhar a combinatória de entrada (de indexação) e, ao mesmo tempo, de saída, no sentido em que estabelece as pontes de acesso ao sistema estrutural ele mesmo (combinatória de entrada).

Veja-se os exemplos de registro da rede lógico-semântica dos termos, tal como se apresenta no Banco de Dados da Linguagem de Representação, apoio para a delimitação dos lay outs para a página da Internet:

\section{TERMO: NASCIDOS MORTOS}

UP: Mortinatos; Natimortos; Óbitos fetais tardios

TERMO EM OUTRO IDIOMA:

IN: Still born

FR: Morts-nés

ES: Nascidos muertos

TT: Demografia

\section{TG: Óbitos}

TR Taxa de natimortalidade

Onde: UP $=$ Usado para

$\mathrm{TT}=$ Top Term ou Tema

$\mathrm{TG}=$ Termo Genérico ou Termo correspondente ao todo (no caso de rel.partitivas).

$\mathrm{TR}=$ Termo Relacionado 
Para uma idéia da rede de relações, veja-se exemplo expandido:

\author{
TERMO: ÓBITOS \\ UP: Mortes \\ TT: Demografia \\ TG: Demografia \\ TE: $\quad$ Óbitos gerais \\ TR Taxa de mortalidade geral \\ TR Índice de mortalidade padronizada \\ Óbitos de menores de 1 ano \\ TE Óbitos neonatais \\ UP Óbitos de 0 a 27 dias \\ TR Taxa de mortalidade neonatal
}

TE Óbitos neonatais precoces

UP Óbitos de 0 a 6 dias

TR Taxa de mortalidade neonatal precoce

TE Óbitos pós-neonatais

UP Óbitos de 28 dias a 11 meses)

UP Óbitos infantis tardios

TR Taxa de mortalidade infantil tardia

TR Taxa de mortalidade infantil

TEÓbitos de mulheres em idade fértil

UP Óbitos femininos de 15 a 49 anos

TR Taxa de mortalidade de mulheres em idade fértil

TEÓbitos perinatais

UP Óbitos fetais + óbitos de menores de 7 dias

TR Taxa de mortalidade perinatal

TENascidos mortos

UP Mortinatos

UP Natimortos

UP Óbitos fetais tardios

TR Taxa de natimortalidade

TEÓbitos por causas de morte

TE Aids

TE Acidentes de veículos a motor

TE Complicações da gravidez, parto e puerpério

TE Homicídios

TE Suicídios

TR Taxa de mortalidade por causas de morte

TR Evasão de óbitos

TR Morbidade

TT Saúde

Ao mesmo tempo que se organiza a linguagem da base de dados, procura-se padronizar as designações a serem utilizadas, propondo uma base de fixação terminológica através da explicitação 
conceitual segundo a qual os termos devem ser interpretados. Concomitantemente, registram-se exemplos de associações não-lineares contempladas pela enunciação. O conjunto desses elementos, mais os de informática (links e recuperação hipertextual) visam permitir maiores condições de viabilizar a apropriação de informações (ou a construção da informação propriamente dita).

A inclusão de Termos Relacionados aumenta a possibilidade de opções ao usuário. Para o leigo, as estatísticas de óbito não são normalmente compreendidas como eventos demográficos, mas como informações de Saúde. Na versão para a Internet, o Tema Saúde pode contar com mecanismos que permitam estabelecer conexões entre áreas de especialidade, seja através de uma remissiva do tipo Veja também, seja através de vínculo hipertextual. Qualquer das hipóteses viabilizam o acesso de um tema a outro.

Do mesmo modo, o acesso a formas variantes. Sinônimos e quase-sinônimos devem ser registrados e disponibilizados como opções de busca - embora a instituição possa eleger uma designação como preferida, ela não deve ser imposta ao usuário. As opções de busca devem, pois, combinar o uso de um modo dedutivo de apresentação e formas mais convencionais de pesquisa - por exemplo, um índice alfabético que mostre simultaneamente a designação preferida e suas variantes.

Grande parte dos sites oferecem opções de idioma de pesquisa. Sob esse aspecto, é essencial que o trabalho de construção de uma linguagem de representação estenda-se à coleta de termos utilizados em outros idiomas (dicionários técnicos, glossários), uma vez que um termo deve ser traduzido a partir do conceito e não da palavra em estado de dicionário. Esse recurso permite substituir procedimentos comumente utilizados na tradução das páginas. 
Veja-se o exemplo:

\section{FICHA DE PROPOSTA DE DEFINIÇÃO}

$\mathbf{N}^{\mathbf{0}} .25$

TERMO: Nascidos vivos

TEMA: DEMOGRAFIA

SINÔNIMOS: Mortinatos; Natimortos; Óbitos fetais tardios

TERMO EM OUTRO IDIOMA: IN: Still born; FR: Morts-nés; ES: Nascidos muertos

FONTES UTILIZADAS PARA CONSTRUÇÃO DA DEFINIÇÃO: 1) Diccionario

Demográfico Multilingue; 2) Thesaurus Popin: 3) Informe Demográfico no. 8, pp.21-22, 1983.

PROPOSTA DE DEFINIÇÃO: São os óbitos fetais com 28 semanas de gestação (óbitos fetais tardios), registrados segundo o local de residência da mãe, num determinado período de tempo. A nova Classificação Internacional de Doenças utilizada a partir de 1996, alterou esse limite para 22 semanas.

OBS.:

1.É necessário distinguir os nascidos mortos dos nascidos vivos que faleceram comminutos ou horas de vida, que são considerados óbitos neonatais precoces (de 0 a 6 dias) .

2. A partir de 1976, a Declaração de Óbito implantada pelo Ministério da Saúde têm auxiliado na distinção entre os nascidos mortos e os nascidos vivos que faleceram com minutos ou horas de vida, através da exigência do registro da hora e do minuto da ocorrência do óbito de nascidos vivos.

RESPONSÁVEIS: Silvia G. Rocha; Marangone; Rute Godinho; Marilda L.G. de Lara.

Data: $16.07 .97 ; 28.08 .97 ; 30.10 .97 ; 02.10 .97$

REVISÃO FINAL: 26.11.97

Já um conceito como "Evasão de Mortes" não tem um termo correspondente em outros idiomas (vejase a ficha terminológica 17 apresentada anteriormente), o que significa que sua tradução a partir da palavra estaria equivocada (Este é um problema não enfrentado seriamente pelas instituições quando seus sites são disponibilizados em idiomas diferentes).

As fichas de proposta de definições não são instrumentos exclusivos para delimitar o conceito dos termos. Mais do que permitir a veiculação de definições consistentes, elas constituem fonte para a identificação das relações entre eles, seja a partir da localização de hiperônimos e hipônimos, seja para o registro das equivalências sinonímicas ou dos termos relacionados. Constituem, portanto, instrumentos fundamentais para a elaboração das combinatórias.

O exercício de linguagem empreendido com parte das informações estatísticas da Fundação Seade permite evidenciar alguns dos benefícios decorrentes da existência de uma base estruturada (muito embora eles nem sempre sejam utilizados porque pressupõem uma contrapartida de desenvolvimento de informática):

a) consulta por "browsing”, ou seja, índice dedutivo, de categorias esubcategorias até o dado específico;

b) consulta através de índice, seja ele alfabético, rotativo ou por termos subordinados a Temas; 
acompanhadas de suas variantes sinonímicas, minimiza-se o problema de buscas irrelevantes, como acontece com a pesquisa através de search engines na Internet; d) permitir, gradativamente, a fixação terminológica na instituição.

Esse exercício permitiu também, levantar as necessidades de investimento em metodologias de identificação de linguagem do usuário, quer no que diz respeito às designações utilizadas, quer em relação às formas de categorização. Além disso, ficou patente a necessidade de investimentos de informática para tornar possível o melhor aproveitamento das possibilidades de busca passíveis de serem desencadeadas a partir de uma linguagem razoavelmente estruturada. Sob este aspecto, verificou-se que o processo de escolhas sucessivas sugerido (o processo dedutivo) implicava inúmeras idas à base de dados (a base com os dados estatísticos propriamente ditos), o que significa tempo na Internet, problema esse que se agrava em razão das inúmeras variáveis a serem agregadas à escolha inicial: nível de agregação geográfica (Estado, Região Administrativa, Região de Governo, Município) e ano ou período desejados. Opções como redução da hierarquia (limitando-se o número de níveis apresentados) ou sua explicitação horizontal (apresentação horizontal dos níveis hierárquicos separados por barra) são exemplos de tentativa de readequação do produto ao usuário.

Ademais, verificou-se que a inteligibilidade não é garantida apenas a partir da definição da linguagem de tratamento e recuperação, mas depende, também, dos recursos de visualização das informações (veja-se, sobre este aspecto, a contribuição de Blair, cap.2.4.3, e a de Rosenfeld \& Morville, cap. 5.6). Esbarra-se novamente, aqui, com problemas de viabilidade de utilização de recursos de informática (ou seu uso adequado) para contemplar uma boa arquitetura de informações.

A experiência relatada através dos poucos exemplos permite afirmar, entretanto, que não é possível pensar em disseminação na ausência de uma linguagem estruturada. Essa experiência permitiu confirmar, por outro lado, a necessidade (e a possibilidade) de construção de mecanismo de busca de natureza sintático-semântica, qualitativamente superior aos mecanismos eminentemente sintáticos como a maior parte dos search engines. Um mecanismo dessa natureza contempla forma e conteúdo, imprimindo às recuperações um modelo onde se assegura melhor a significação. Enquanto via de acesso ‘centralizadora', esse mecanismo pode refletir uma linguagem institucional, possibilitando imprimir um padrão homogêneo à recuperação do universo de informações e evitando, assim, problemas de navegação no interior do site à procura de informações.

De fato, as instituições de estatística de um modo geral carecem de mecanismos para o melhor aproveitamento de suas informações, já que sob a multiplicidade de designações isoladas, acabam por falhar na consecução dos seus objetivos de transparência e democratização da informação. Se a via centralizadora tem seus defeitos, pois dirige a interpretação, espelha a possibilidade de, a partir de um parâmetro claro e definido, permitir acesso e usos variados da informação. A padronização funciona, nesse sentido, como meio para promover a circulação de informações. 


\section{EXEMPLO 2: A representação de informações sobre serviços públicos - o Guia de Informações sobre Serviços Públicos}

Ao lado das informações textuais, tradicionalmente reconhecidas como "informações", as instituições públicas devem disponibilizar informações de diversas naturezas, inclusive relativa aos seus serviços. Dentro desse espírito insere-se o Poupatempo - Central de Atendimento ao Cidadão, projeto da Secretaria de Governo e Gestão Estratégica do Estado de São Paulo, em parceria com a Fundação para o Direito Administrativo - FUNDAP e a Cia. de Processamento de Dados do Estado de São Paulo - PRODESP. Dentro do Programa de Informação e Informatização do Estado (SÃO PAULO (Estado) Sec.Gov.Gestão Estratégica \& PRODESP, 1997), seu objetivo é o de disponibilizar, inicialmente ao público da cidade de São Paulo (já estão em gestão outras unidades no interior do Estado), os serviços públicos institucionais mantidos pelo Estado e, em alguns casos, pela Federação.

Um dos produtos do projeto é o Guia de Informações sobre os Serviços Públicos, concebido a partir das seguintes constatações: $90 \%$ da população desconhece os requisitos e procedimentos necessários para o acesso aos serviços públicos; a linguagem utilizada pelos órgãos é excessivamente técnica; não há, na maioria das vezes, normas e padrões que regem os requisitos e procedimentos; não há divulgação dessas informações ou seu acesso é restrito" (TOKAIRIM, V.L., coord., 1998).

As agências do Poupatempo reúnem, fisicamente, um grande número de serviços públicos e deverão contar, proximamente, com uma versão do Guia a partir do qual será possível obter informações sobre a maior parte dos serviços públicos estaduais (e alguns federais). Essa base referencial estará nos Totens Multimídia, podendo também ser acessada remotamente via Rede Notes do Estado e via Internet (idem ibidem). A experiência aqui relatada refere-se à elaboração de uma linguagem de representação e recuperação para esse Guia.

O universo de informações do Guia de Informações sobre os Serviços Públicos ${ }^{29}$ compreende distintos serviços relativos a diferentes órgãos, que contemplam, por sua vez, níveis heterogêneos de especificidade no tratamento de suas informações. Elaborar um vocabulário único para a representação desses serviços solicita, conseqüentemente, proceder ora a generalizações, ora a especificação, para colocar, lado a lado, a oferta de serviços similares, se não em conteúdo, pelo menos em forma.

A criação de uma linguagem de representação desse gênero evidencia a necessidade de desenvolver um trabalho de compatibilização de vocabulários, uma vez que se enfrenta, simultaneamente, distintos

29 Participamos do projeto enquanto consultora. 
discursos: o discurso oficial, os discursos dos variados grupos profissionais de cada instituição pública e os discursos da população, estes também não homogêneos. As contribuições da Socioterminologia (cap. 4.7) são, nesse sentido, fundamentais, face a ênfase que colocam nas situações de comunicação e na oralidade.

Consoante aos objetivos de ampla disseminação procurou-se, na elaboração desse vocabulário, a simplicidade, reduzindo a explicitação da complexidade das relações à combinatória de controle. Do ponto de vista do enunciador (considerando, aqui, os órgãos públicos), verificou-se que as primeiras dificuldades decorrem do próprio entendimento dos registros dos serviços institucionais, ou porque se utiliza um jargão excessivamente hermético, ou porque os órgãos, eles mesmos, não têm muita clareza sobre o que oferecem. "A burocracia que vive para as suas regras e não para a população que demanda/necessita de seus serviços ... só raramente consegue enunciar adequadamente o serviço que presta ao cidadão e o que este deve fazer para solicitá-lo" (SAMPAIO \& PARENTE, 1997, p.5). De fato, a consecução de objetivos de democratização da informação pressupõe, anteriormente, a capacitação da administração pública para informar, sem a qual o próprio acesso é comprometido (idem ibidem, p.1). Acresça-se a isso, a dificuldade implicada pela possibilidade de divulgação dos serviços (seus objetivos, tempo para obtenção, horários de atendimento, locais de sua disponibilização), uma vez que ela gera, necessariamente, maior possibilidade de cobrança por parte da população. Fornecer uma informação, é conferir poder àquele que a recebe (idem ibidem, p.5).

A construção de uma linguagem de representação e recuperação não prescinde, portanto, de um trabalho inicial junto aos próprios prestadores de informações, visando identificar ou introduzir padrões mínimos para a designação e descrição dos serviços, bem como para as formas e requisitos para sua obtenção. Muitas vezes, os próprios órgãos não têm clareza sobre as implicações das formas através das quais solicitam documentação. Veja-se os exemplos:

Ex: "última conta paga", requer precisar:

- última conta paga pelo usuário?

- última conta emitida pela instituição, paga?

A expressão "não possuir débitos" permite anular a ambigüidade das frases anteriores, constituindo-se padrão para pré-requisitos similares.

Ex.: "comprovante de residência" não fornece parâmetros claros de interpretação.

Substituindo-a por "Conta de luz ou conta de água ou declaração de residência com firma reconhecida", o usuário é remetido aos documentos concretos normalmente aceitos como comprovantes de residência. 
As formas alternativas de denominação atribuídas aos serviços, pela população, também são objeto de coleta, uma vez que fornecem elementos para a identificação de possíveis formas de acesso. Um serviço oficialmente denominado Emissão de primeira via de RG: cidadão brasileiro nato-POLÍCIA CIVIL, é muito procurado por Carteira de identidade.

A preocupação em articular uma linguagem de entrada (indexação dos serviços, categorização) à linguagem de saída (índice) remeteu ao uso de uma combinatória que integrou pré e póscoordenação de termos. De fato, a pós-coordenação recomendada pelas normas de tesauro, além de ser mais sofisticada para ser utilizada pelos usuários, pode trazer recuperações inconsistentes quando o universo objeto de representação compreende distintas áreas de atividade ou quando não tem terminologia fixada. O uso combinado de pré e pós coordenação decorreu, também, da necessidade de equilibrar volume de serviços e níveis de especificidade de tratamento diferentes dados aos vários serviços pelos órgãos responsáveis. Um serviço específico não passível de ser reunido com outros similares recebeu, muitas vezes, um tratamento individualizante, contrariamente ao que aconteceu com serviços referentes a um tema comum.

A estrutura básica contemplou dois níveis: categorização dos serviços e indexação individual. $\mathrm{Na}$ categoriazação procurou-se evitar o uso do jargão oficial já que, de fato, o reconhecimento de um tema não coincide, necessariamente, com a denominação das atividades dos órgãos responsáveis. Por exemplo, 'Saneamento' identifica a atividade principal da SABESP, porém traduz-se mais simplesmente em ‘Água e Esgoto’. Recurso para reunir serviços similares, a categorização (através de Temas), apresentou-se, na realidade, mais como um recurso de controle vocabular, já que de não se pode esperar esse nível de abstração por parte de toda a população, embora os Temas tenham sido explicitados como itens de consulta face à necessidade de contemplar públicos distintos.

Na indexação individual dos serviços procurou-se observar as características de um usuário extremamente heterogêneo, que tem, muitas vezes, dificuldades de formular exatamente o que quer ou necessita. Procurou-se indexar os serviços a partir de vários de seus aspectos, gerando tantas entradas quantos fossem as características a serem privilegiados.

O conjunto de Temas e Assuntos constitui um índice. Nos dois casos, a designação utilizada é constituída de palavras que se aproximam de termos mas também tendem a reproduzir a oralidade - com a busca por palavras que compõem esses mesmos Assuntos. Da mesma forma são tratados os Temas, já que são passíveis de serem localizados quer pela primeira palavra ou por quaisquer outras que componham a expressão temática. Esta forma deíndice reproduz, a seu modo, a fórmula de um antigo instrumento - o KWIC - Key Word In Context - cujo princípio era o de marcar, para consulta, termos considerados significativos relativos aos assuntos encontrados nos textos, disponibilizando-os através de um índice rotativo ou permutado. 
A vantagem desse tipo de índice é que ele é mais fácil de ser consultado se comparado àqueles que solicitam a combinação de termos (recuperação por pós-coordenação).Atende, também, a uma limitação dada pelo software escolhido pela PRODESP para o sistema. A solução adotada, portanto, aproxima-se dos Cabeçalhos de Assunto, já que trás prontos os índices a serem pesquisados, porém não se confunde inteiramente com eles, uma vez que entradas separadas contemplam a representação de conceitos diferentes. Um mesmo documento é simultaneamente indexado sob Débito automático e Contas de gás, mas as entradas são distintas, o que não ocorreria com um Cabeçalho de Assunto que realizaria, de forma pré-coordenada, a junção Contas de gás - Débito automático.

Veja-se o exemplo abaixo:

Abastecimento de água por carro-tanque será apresentado três vezes na ordenação alfabética, conforme a letra inicial considerada:

Abastecimento de água por carro-tanque

Abastecimento de água por carro-tanque

Abastecimento de água por carro-tanque

Os sinônimos (ou as diversas modalidades de variantes não necessariamente de natureza sinonímica) integram o índice permutado com o mesmo valor das entradas consideradas principais (ou seja, são considerados apenas para controle vocabular), procurando-se, através desse recurso, simplificar a busca. Seu número, entretanto, foi significativamente reduzido, uma vez que se procurou compor os termos de indexação de forma a integrar, neles, suas principais variantes. A rotação dos termos que compõem a entrada de indexação permite acesso, se não às palavras correspondentes às variantes propriamente ditas, a palavras que têm radicais semelhantes.

Exemplos de sinônimos:

Postagem de valores

Variante: Remessa de dinheiro

Preços da cesta básica

Variante: Preços de alimentos básicos

Carteira de trabalho

Variante: Carteira profissional

Contas de energia elétrica

Variante: Conta de luz 
Se do ponto de vista do controle vocabular as siglas conhecidas foram preferidas às formas por extenso, no índice ambas são passíveis de recuperação por serem admitidas como formas sinonímicas.

Exemplo:

FGTS
Variante: Fundo de Garantia por Tempo de Serviço
IPVA
Variante: Imposto sobre Propriedade de Veículos Automotores
Mas:
Carteira de Identidade
$\quad$ Variante: $R G$

A proposta de linguagem será submetida a teste para verificar sua adequação. Na realidade, a definição das formas para representação e recuperação deste gênero de informações não dispensa um trabalho de coleta oral (as formas alternativas de identificação dos serviços foram coletadas através dos órgãos participantes), já que a apropriação das informações depende, necessariamente, da integração dos saberes da população a que se dirige. De fato, normalmente "a produção de estoques de informação orienta-se por uma racionalidade técnica e produtivista", porém sua apropriação está condicionada a uma limitação contextual e cognitiva. "Para intervir na vida social, gerando conhecimento ... a informação necessita ser transmitida e aceita como tal”, já que "os espaços sociais não são homogêneos como o processamento técnico dos estoques de informação" (BARRETO, 1994.p.5).

Realmente, a atividade de representação tem sido desenvolvida marcadamente centrada no emissor, desconsiderando, ou minimizando, os problemas relativos à comunicação. Esse modelo não enfrenta convenientemente o fato de que a transferência da informação só se realiza na medida em que táticas e estratégias de distribuição considerem o espaço social onde ela se realiza.

É esclarecedora a observação de Boaventura Santos, que caracteriza a produção e aplicação do conhecimento através de quatro contextos estruturais que se articulam entre si: o contexto doméstico, o contexto do trabalho, o contexto da cidadania e o contexto da mundialidade. "Cada um dos contextos é um “mundo de vida” servido por um saber comum” (SANTOS, 1989, p.152).

Focalizando o contexto da cidadania - o cidadão é o alvo do Poupatempo - , é necessário considerar as relações entre o Estado e o indivíduo. O cidadão, como todos nós, é atravessado por seres práticos que se articulam e se interpenetram: o ser da família, o ser da classe, o ser do 
indivíduo e o ser da nação. Cada um desses seres é produto-produtor de sentido, e por essa razão, nossa ação em sociedade é uma configuração de sentidos. A cada uma das comunidades, entretanto, corresponde uma forma específica de interação comunicativa. É necessário, pois, criar condições para que todas as dimensões da comunicação e do processo de cooperação interpretativa sejam potencializadas na sua eficácia, não se esquecendo que elas vivem em tensão permanente e que muitas vezes disfarçam-se em comunicação genuína, sendo apenas sucedâneos de comunicação. (“O senso comum inclui a aceitação não problemática das condições que são responsáveis pelo fechamento do sentido e a restrição da comunidade”) (idem ibidem, p. 155).

A tensão latente ou manifesta que constitui nossa quotidianidade se realiza diferentemente conforme o contexto estrutural em que ocorre, já que um tipo de poder específico subjaz a cada um deles. No contexto da cidadania, o mecanismo de poder é o da dominação, a forma institucional desse poder é o Estado, o modo de racionalidade dominante é o da "maximização da lealdade" (do indivíduo ao Estado).

O Poupatempo pretende interferir nesse contexto para minimizar a tensão que afeta, particularmente, os cidadãos. É evidente que sendo caracterizado como uma ação desenvolvida a partir do Estado, mesmo que se preocupe com a diminuição do 'estranhamento' (indiferença, intimidade acrítica e rotineira) do 'silenciamento' (desinteresse), trabalha-se com ferramentas do Estado. Porém, a intervenção que pretende realizar procura observar as condições da mediação com a intenção de diminuir os desequilíbrios entre as formas como disponibiliza informação (papel do Estado) e as formas como os indivíduos a recebem (os cidadãos). Dito de outra maneira, pretende equilibrar as relações entre o estoque de conhecimento do Estado e o do cidadão. Nesse sentido, preocupa-se em considerar os elementos da racionalidade das comunidades a que se dirige, e tenta pautar seus procedimentos nas propostas de uma ação que poderia ser caracterizada como edificante.

Isso confirma, pois, a necessidade de que a linguagem construída para a interface do Guia seja testada, procedendo-se à pesquisa quanto à sua aceitabilidade e adequação frente aos 'estranhamentos e silenciamentos'. Como já afirmamos, a grande dificuldade em trabalhar sob esse novo enfoque é a ausência de exemplos, pois só muito recentemente o Estado admite como pública sua informação.

Apesar da consciência da necessidade de adotar estratégias específicas de tratamento, arranjo e distribuição e, conseqüentemente, de utilizar linguagens que não sejam marcadas pela técnica, caminha-se, muitas vezes, sem saber como romper a distância que tem historicamente separado as esferas da produção e da recepção. É preciso dizer que, no desenvolvimento deste trabalho, muitas vezes não foi possível generalizar procedimentos, manter critérios e adotar padrões homogêneos de construção das representações. 


\section{EXEMPLO 3: A representação da informação sobre sistemas governamentais - o Guia da Oferta de Informações e Sistemas do Governo do Estado de São Paulo}

Parte do Sistema Estratégico de Informações da Secretaria de Governo e Gestão Estratégica do Estado de São Paulo, o Guia da Oferta de Informações e Sistemas ${ }^{30}$ (em sua 2a. edição) é um catálogo de referência e acesso às informações organizadas em bases informatizadas existentes nos órgãos públicos da administração estadual. Seus objetivos são os de dar visibilidade ao acervo de informações do Estado, facilitar seu acesso e estimular o seu uso, bem como contribuir para diminuir a duplicação de esforços na montagem de sistemas assemelhados em finalidade e conteúdo na administração pública direta e indireta do Estado de São Paulo através do intercâmbio de experiências entre os órgãos.

O trabalho de construção de uma linguagem de representação para o Guia da Oferta teve seu início na reconstrução do questionário de coleta, para identificar, entre outras, as características da natureza dos sistemas, seus objetivos e conteúdo das informações (para o questionário, ver anexo). A polissemia, que caracteriza a palavra "sistema" foi, neste caso, fonte de problemas, uma vez que as definições formais existentes nos vários tipos de dicionários - particularmente os de Informática - não forneceram elementos suficientemente claros para realizar uma delimitação precisa e distintiva. O trabalho terminológico aí iniciado mostrou que inexiste uma definição consensual e amplamente compartilhada para o termo, razão pela qual optou-se por combinar elementos colhidos dos vários dicionários consultados com os dados da experiência empírica.

Para permitir que as respostas tivessem um relativo grau de consistência, procuramos utilizar vários recursos quepermitissem induziro informante à definição com a qual implicitamente trabalhávamos: uso simultâneo de sistema de informações/banco/base de dados; explicação do termo inserida junto ao item relativo à identificação do sistema (item 2): "entende-se por sistema de informações o conjunto de dados armazenados de forma sistêmica recuperáveis via computador"; através da pergunta "Para que serve o sistema" (item 3.1), inserida no item mais geral "Objetivo e conteúdo do sistema de informações/banco/base de dados" (item 3), e acompanhada pela explicação: "Descreva detalhadamente a finalidade e as funções do sistema"; através da solicitação de uma caracterização genérica: "Assinale a natureza do sistema" (item 3.2), acompanhada de uma instrução: "Selecione uma opção a partir das características que melhor identiquem o sistema" não totalmente fechada ("outros"); e, finalmente, através de um detalhamento das informações cobertas pelo sistema: "Relacione os assuntos específicos cobertos pelo sistema de informações" acompanhada de exemplos. Ou seja: procurou-se recuperar informações contextuais relativas aos sistemas para que fosse possível operar a partir de uma definição razoavelmente homogênea.

30 Projeto interinstitucional entre a Sec. Governo e Gestão Estratégica, a Fundação SEADE e a PRODESP. Participamos do projeto como consultora. 
A categorização utilizada no questionário (que teve como fonte os temas do Guia anterior, o Plano de classificação das atividades da Universidade de São Paulo, 1997, e a classificação utilizada nos questionários do $\mathrm{CNPq}$ ), embora tenha facilitado o trabalho de tabulação das respostas, teve que ser refeita a partir dos resultados dos questionários. Comprovou-se, neste caso, a dificuldade de estabelecer critérios de generalização quando o universo de trabalho é muito amplo e heterogêneo.

\section{EXTRATOS DO QUESTIONÁRIO}

\section{IDENTIFICAÇÃO DO SISTEMA DE INFORMAÇÕES/BANCO/BASE DE DADOS:}

Entende-se por sistema de informações o conjunto de dados armazenados de forma sistêmica.

\subsection{Nome do sistema:}

etc.

\section{OBJETIVO E CONTEÚDO DO SISTEMA DE INFORMAÇÕES/BANCO DE DADOS/BASE DE DADOS}

3.1 Para que serve o sistema?

Descreva detalhadamente a finalidade do sistema.

\subsection{Assinale a natureza do sistema:}

Selecione uma opção a partir das características que melhor identifiquem o sistema.

Banco de dados estatísticos. Banco de dados bibliográficos/acervos informacionais; Banco de dados cadastrais; Banco de dados jurídicos* (a)

Sistema administrativo/financeiro e de contabilidade** (a)

Outros (especifique):

\section{2a Assinale o tema geral coberto pelo sistema:}

Esta lista de temas é apenas indicativa. Utilize a opção "Outros" para os sistemas que não se enquadram nos temas relacionados abaixo. Assinale mais de uma opção quando necessário. Opção subordinada aos sistemas assinalados com *:

(a) Os asteriscos são utilizados para indicar as áreas de vínculo de hipertexto. 


\section{TEMAS GERAIS (b)}

\section{Administração Pública}

Ex.: dados estatísticos sobre os municípios paulistas; cadastro de autoridades públicas; base bibliográfica sobre experiências municipais; leislação sobre uso do solo; etc.

\section{$\square$ Agricultura}

Ex.: dados estatísticos sobre produção agrícola; cadastro de produtores de sementes; base bibliográfica sobre cultivo de frutas tropicais; base de dados de legislação sobre reforma agrária; etc.

\section{Educação}

Ex.: estatísticas sobre matrículas nas escolas de 1o. grau: cadastro de delegacias de ensino; base bibliográfica sobre educação de deficientes; legislação sobre ensino supletivo; etc.

\section{$\square$ Saúde}

Ex.: estatísticas sobre leitos hospitalares; base bibliográfica sobre saúde pública; cadastro de centros de saúde; etc.

Outros (especifique):

(b) O questionário comtempla 24 temas.

\section{2.b Assinale a função principal do sistema de informações:}

Opção subordinada aos sistemas assinalados com **

\section{FUNÇÕES (c)}

\section{$\square$ Gestão de Bens Imóveis}

Inclui administração patrimonial de bens imóveis, etc.

$\square$ Gestão de materiais, equipamentos, mobiliário e/ou veículos.

Inclui controle de estoque; frota; cadastro de fornecedores, etc.

...

\section{$\square$ Gestão de Recursos Humanos e Benefícios}

Inclui controle de freqüencia; folha de pagamento; admissão e demissão de pessoa: contagem de tempo de serviço; convênios médicos; cadastro de consultores; etc. ...

\section{$\square$ Sistema de Apoio ao Planejamento e Gestão}

Ex.: Gestão de serviços de saúde; gestão de transportes públicos, etc.

$\square$ Outros (especifique):

(c) O questionário comtempla 10 funções. 
A tabulação dos questionários constituiu uma segunda fase de tratamento vocabular que exigiu a redefinição de categorias de agrupamento e a definição das entradas de indexação individual dos sistemas. Muitas das categorias anteriormente utilizadas mostraram-se inoperantes ou insuficientes para dar conta das características dos sistemas, porém no processo de recategorização identificamos inúmeras lacunas lexicais. Além disso, observou-se que a função dos sistemas não deveria estar restrita aos sistemas administrativos, financeiros e de contabilidade, conforme o questionário, muito embora, nesses casos, ela estivesse mais evidente. Observou-se, também, que os sistemas poderiam ser classificados simultaneamente pela sua natureza e pela sua função, a partir das características colocadas em jogo em cada caso.

A alternativa para contemplar a natureza dos sistemas foi a de criar dois grandes blocos: as Bases de Dados e os Sistemas Gerenciais, sob as quais se organizam subtipos específicos. Sob as Bases de Dados, subcategorias como Bases de dados estatísticos, Bibliográficos, Estatísticos etc.; sob Sistemas Gerenciais, subcategorias por tipo de gestão que realizam: Gestão de serviços de saúde, Gestão de serviços de transportes, Gestão de recursos humanos, Planejamento e execução orçamentária etc.. Os sistemas foram classificados simultaneamente em mais de uma categoria - e/ou várias subcategorias, sempre que necessário.

Arigor, os Sistemas Gerenciais distinguem-se em: sistemas dedicados à rotinas administrativo-financeiras e macro-sistemas, ou seja, sistemas que produzem informações gerenciais especificamente relacionados à atuação principal dos órgãos . Essa distinção, entretanto, não foi objeto de separação. As sub-categorias dos sistemas gerenciais podem ser diretamente explicitadas pelas funções que exercem, o que não ocorre com as bases de dados para as quais foi necessário especificar temas (por exemplo, Administração Pública, Meio Ambiente, Segurança Pública, Agropecuária etc.).

Esse exercício de categorização-seja pornatureza, função ou tema-revelou as dificuldades operacionais de trabalhar a partir de características, pois nem sempre elas são claramente formuladas. Porém, não haveria outra maneira de facilitar o acesso a cerca de 800 sistemas cadastrados. A dupla (ou tripla) classificação foi o recurso utilizado para evitarperda de informações.

$\mathrm{Na}$ indexação individual de cada sistema procurou-se revelar sua especificidade. Além das informações fornecidas pelo questionário no item correspondente (3.3), muitas vezes foi necessário recorrer a outros itens (relacionados ou não ao conteúdo dos sistemas) para que, a partir de sua contextualização, fosse possível identificar sua especificidade.

Dada a diversidade de informações sobre cada sistema, a definição da interface de busca procurou contemplar várias possibilidades de acesso, visando permitir a visualização do conjunto de ambientes a partir dos quais um sistema pudesse ser procurado e recuperado. Vejam-se alguns exemplos de possibilidades de entrada: 
Consulta por Órgãos, Sistemas, Temas ou Funções e Palavras-chave (opção visualizada por default, primeira página do Guia):

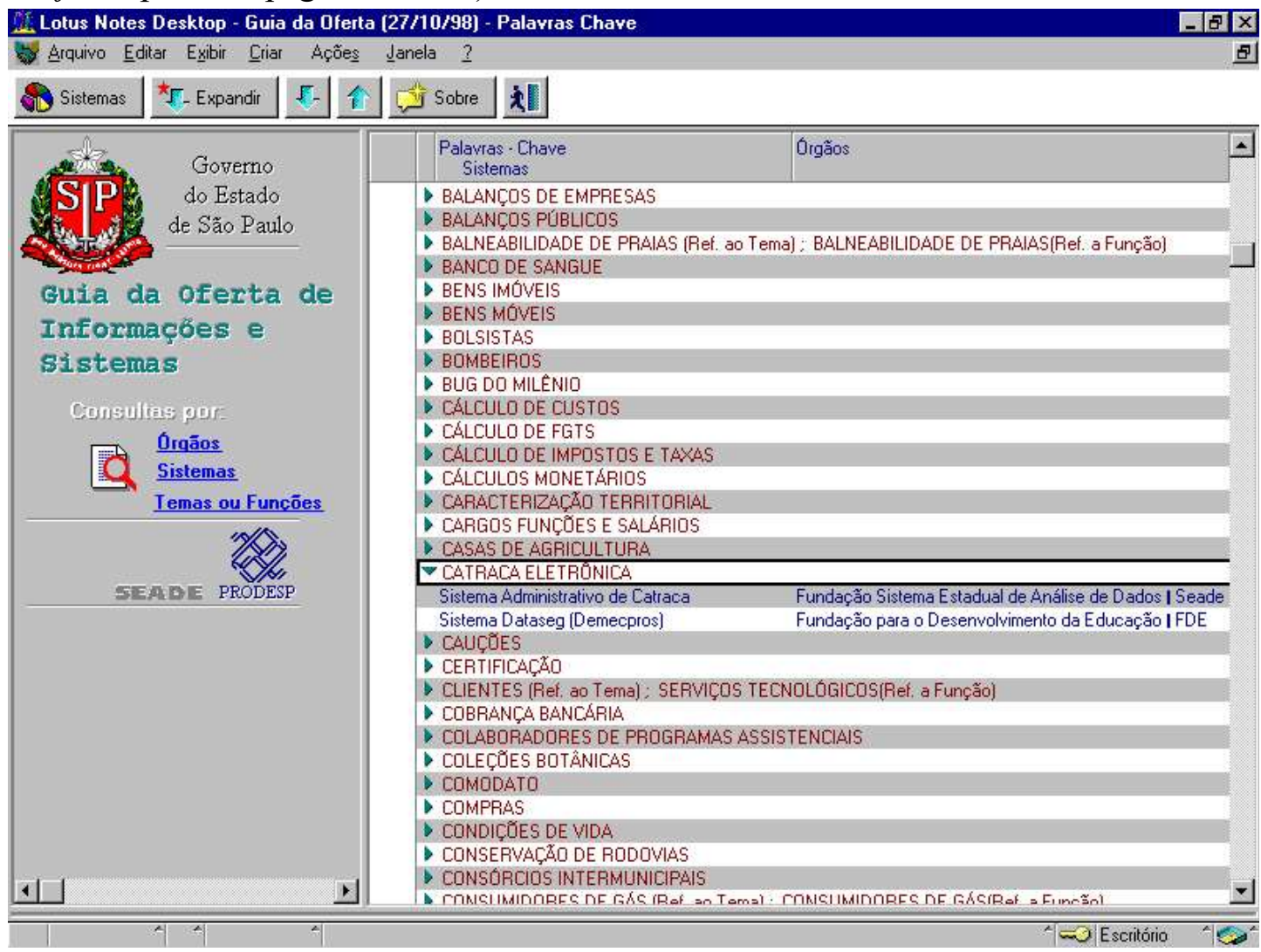

\section{Consulta por Temas ou Funções:}

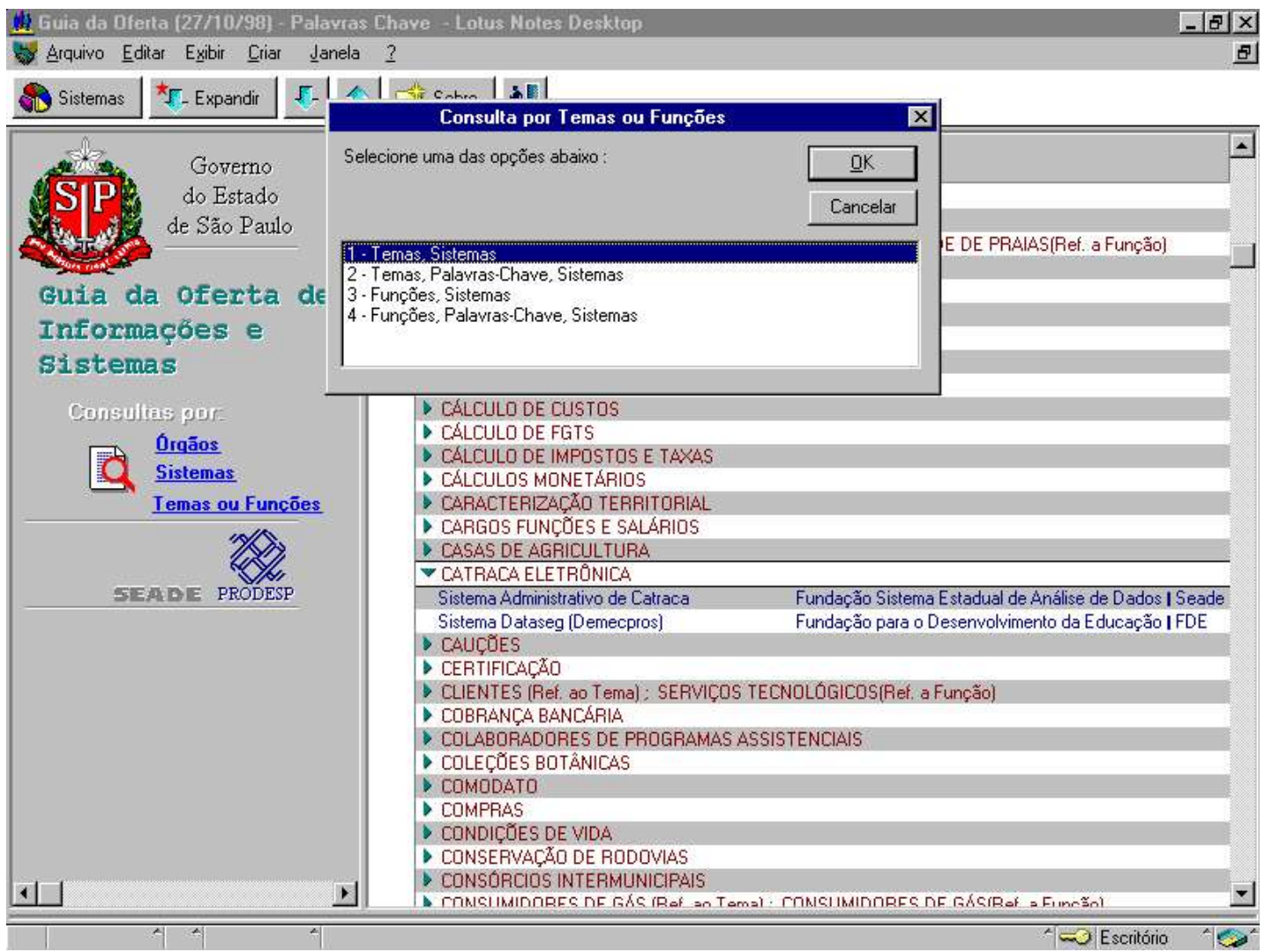


Consulta por Temas/Palavras-chave/Sistemas:

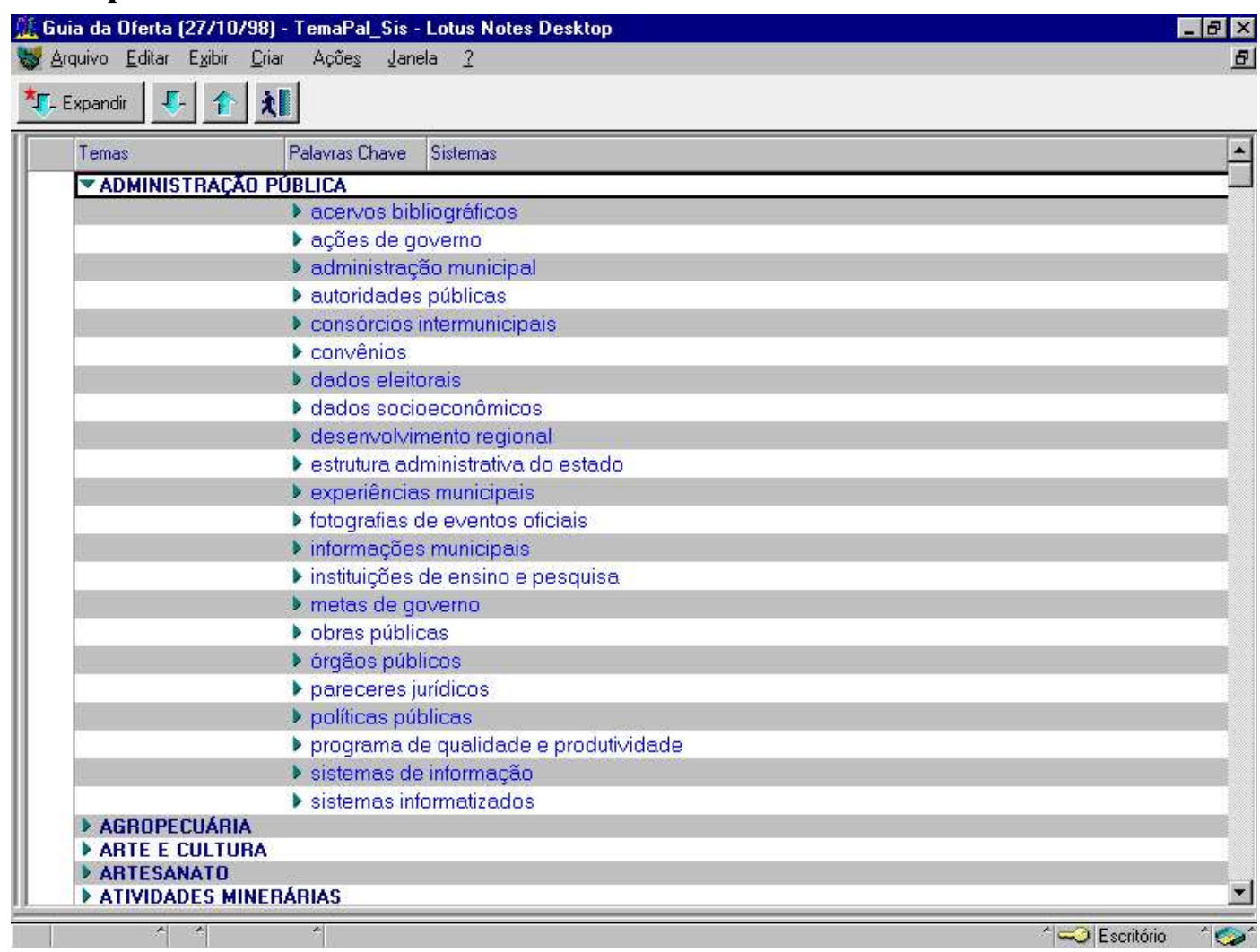

\section{Consulta por Funções/Sistemas:}

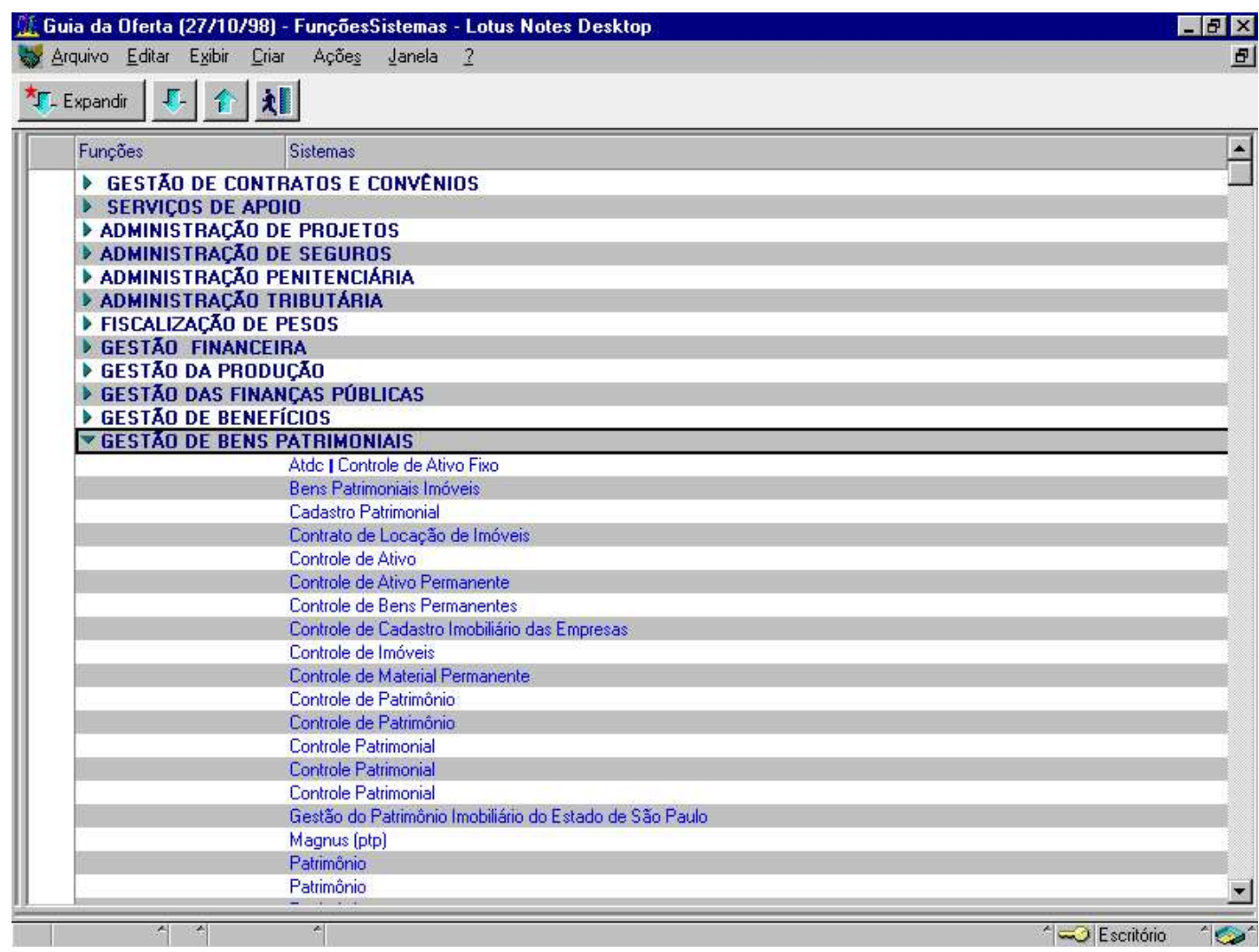


Consulta por Funções/Palavras-chave/Sistemas:

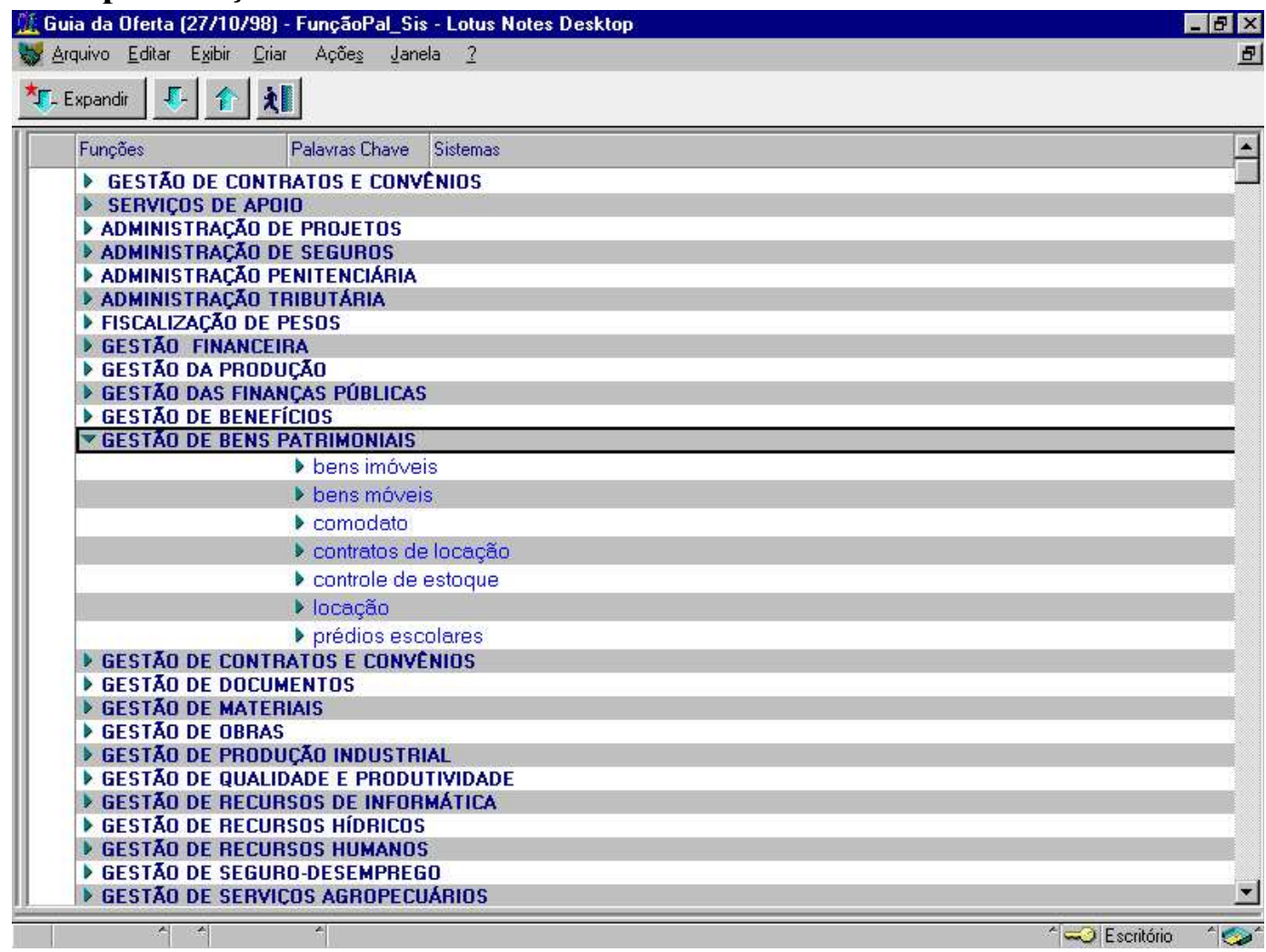

\section{Consulta por Órgãos/Secretarias/Sistemas:}

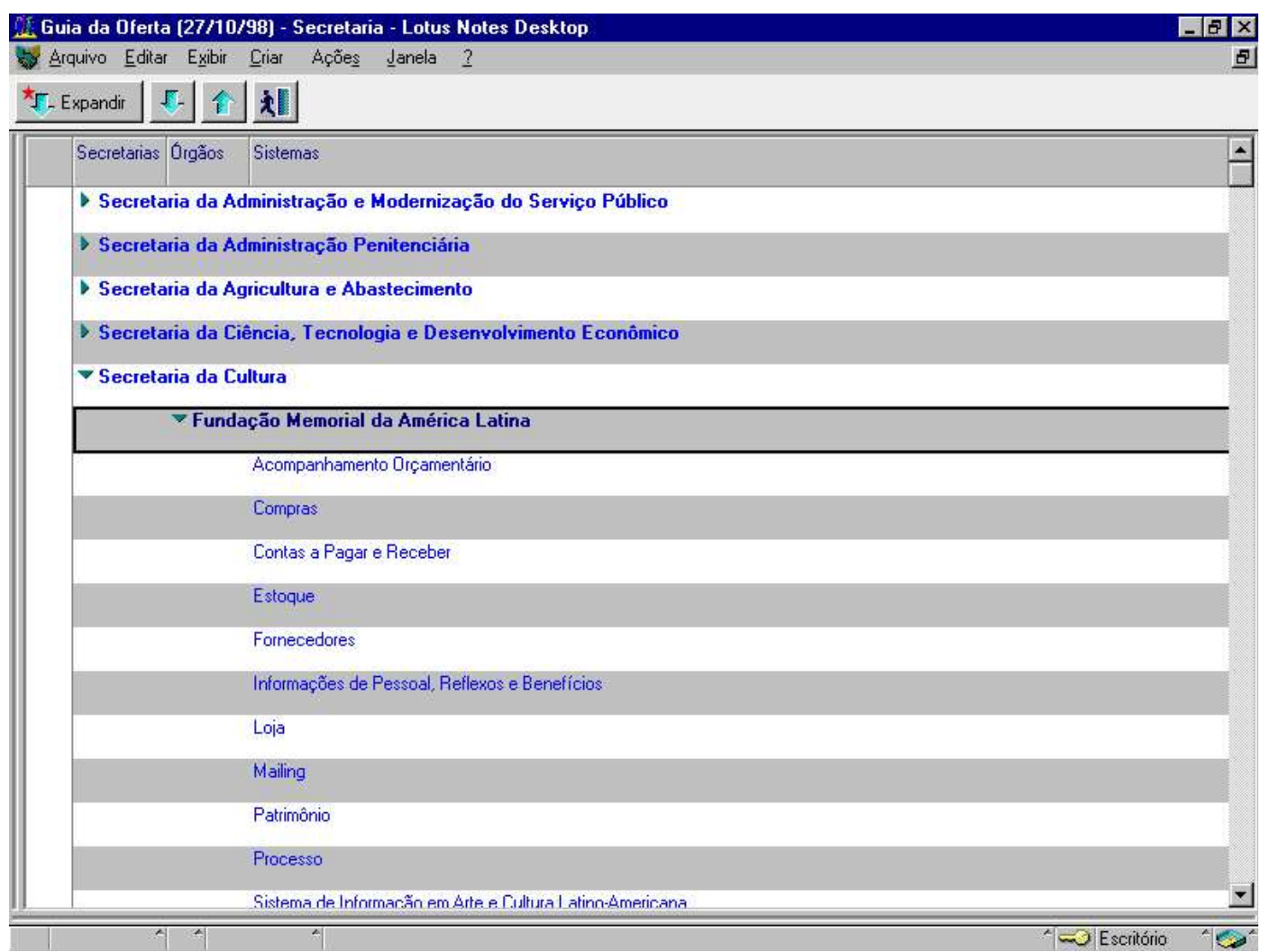




\section{Consulta por Sistemas//Orgãos/Palavras-chave}

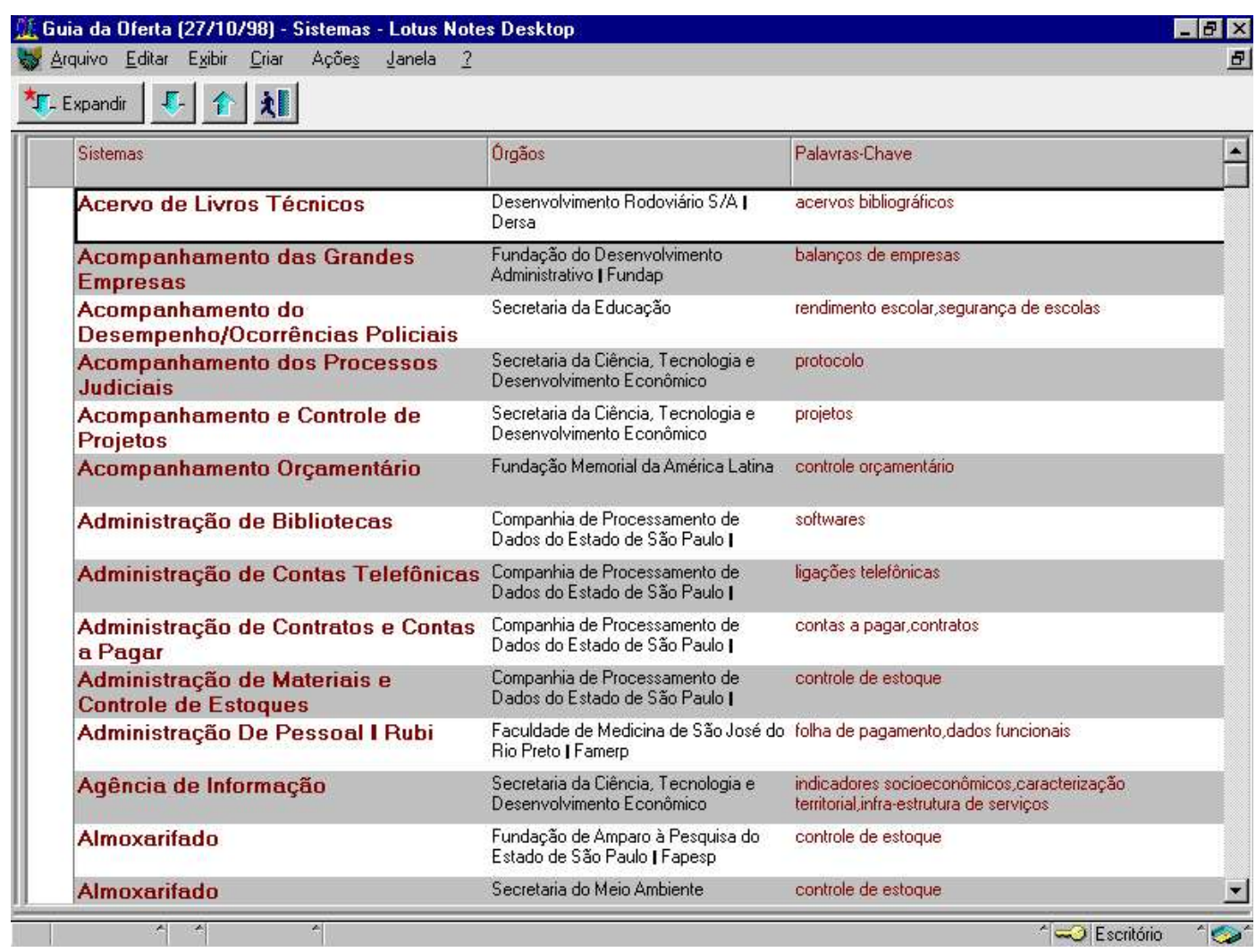

Quaisquer das possibilidades remetem diretamente à informação - uma versão editada e normalizada das respostas ao questionário.

O Guia está disponibilizado para consulta na Rede Notes do Estado e deverá integrar, brevemente, a página do Governo do Estado de São Paulo na Internet. O investimento atual dirige-se à sua crítica, tanto no que diz respeito às informações veiculadas como no que tange à sua linguagem propriamente dita. 


\section{REFERÊNCIAS BIBLIOGRÁFICAS/BIBLIOGRAFIA}

\section{INFORMAÇÃO/DOCUMENTAÇÃO/ANÁLISE DOCUMENTÁRIA}

AITCHISON, J. \& GILCHRIST, A.(1979). Manual para construção de tesauros. Rio de Janeiro: BNG/Brasilart.

AMARO, R.K.O.F. (1991). Contribuição da análise do discurso para a análise documentária: o caso da documentação jornalística. São Paulo: ECA-USP. (Dissertação de Mestrado).

AUSTIN, D. \& DALE, P. (1993). Diretrizes para o estabelecimento e desenvolvimento de tesauros monolingües. Trad. de Bianca Amaro de Melo e rev. de Lígia Maria Café de Miranda. Brasília : IBICT; SENAI.

BAITELLO JUNIOR, N. (1994). A sociedade da informação. São Paulo em Perspectiva: revista da Fundação SEADE, v.8. n.4, p.19-21.

BARITE, M. (1990). Reformulación de tablas notacionales. Montevideo, Ed. El Galeón.

BARRETO, A. de A. (1994) A questão da informação. São Paulo em Perspectiva: revista da Fundação SEADE, v.8, n.4, p.3-8.

CAMPOS, M.L.A. (1994) Em busca de princípios comuns na área de representação da informação: uma comparação entre o método de classificação facetada, o método de tesauro baseado em conceito e a teoria geral da terminologia. Rio de Janeiro: URFJ. (Tese de mestrado)

CHARTIER, R. (1994). A ordem dos livros: leitores, autores e bibliotecas na Europa entre os séculos XIV e XVIle. Brasília: Ed. Universidade de Brasília: 1994.

CLASSIFICAÇÃO DECIMAL UNIVERSAL - CDU. (1987) Ed. média em língua portuguesa. Brasília: IBICT. 2 v. (Publicação FID, n.665)

CHAUMIER, J. (1971). As línguas documentais. In:- _ As técnicas documentais. Lisboa: Europa América. cap. 4, p.50-77.

CHAUMIER, J.(1978). Les langages documentaires: le traitement linguistique d'information documentaire. Paris: Entreprise Moderne d'Edition.

CINTRA, A.M.M. (1987). Estratégias de leitura em documentação. In: SMIT, J.W. (org.). Análise documentária: a análise da síntese. Brasília: IBICT, p.28-35.

CINTRA, A.M.M.; TÁLAMO, M.F.G.M.; LARA, M.L.G \& KOBASHI, N.Y. (1994) Do termo ao descritor: estudo exploratório. Revista Comunicações e Artes, São Paulo, v.17, n.18, p.75-82, 1994.

CINTRA, A.M.M.; TÁLAMO, M.F.G.M.; LARA, M.L.G \& KOBASHI, N.Y.(1996). Linguagens Documentárias e terminologia. In: ALVES, I.M. A constituição da normalilzação terminológica no Brasil. São Paulo: FFLC/CITRAT. (Cadernos de terminologia, 1).

CINTRA, A.M.M.; TÁLAMO, M.F.G.M.; LARA, M.L.G. de \& KOBASHI, N.Y.(1994). Para entender as Linguagens Documentárias. São Paulo: APB/Polis. 
CINTRA. A.M.M. (1983). Elementos de lingüística para estudos de indexação. Ciência da Informação, Brasília, v.12, n.1, pp.5-22.

COYAUD, M.\& SIOT-DECAUVILLE, N. (1967). L'analyse automatique des documents. Paris: Mouton.

COYAUD, M.(1966). Introduction a l'étude des langages documentaires. Paris: C. Klincksieck.

CUNHA, I.M.R.F., org. (1989). Análise documentária: considerações teóricas e experimentação. São Paulo: FEBAB.

CUNHA, I.M.R.F.C. (1990). Do mito à análise documentária. São Paulo: EDUSP. (Teses, 11)

DAHLBERG, I. (1978). Fundamentos teórico-conceituais da Classificação. Revista de Biblioteconomia de Brasília, v.6, n.1, p.12, jan./jun.

DAHLBERG, I. (1978). Teoria do conceito. Ciência da Informação, Rio de Janeiro, v. 7, n.2, p.101-107.

DEWEY DECIMAL CLASSIFICATION deviced by Melvil Dewey. (1989) 20.ed. Ed. by J. P. Comaromi et alii. Albany, N.Y.: Forest Press. 4v.

FOSKETT, A.C. (1973). A abordagem temática da informação. Brasília; São Paulo: UnB; Polígono.

FOSKETT, D.J. (1967). Classificação. In: ASHWORTH, W. Manual de bibliotecas especializadas e de serviços informativos. Lisboa: Fund. Calouste Gulbenkian. p.89-158.

GARCÍA GUTIÉRREZ, A. (1990). Estructura linguística de la documentación: teoría y método. Murcua: Ed. Universidad de Murcia.

GARDIN, J.-C. (1968). Análise documentária e análise estrutural em arqueologia; trad. de J. T. Coelho Netto. In: CORDIER, S., ed. Lévi-Strauss. São Paulo: Documentos. pp.81-86.

GARDIN, J.-C. (1970). Procédures d'analyse sémantique dans les sciences humaines. In: POUILLON, J. et MARANDA, P. (orgs.). Échanges et communications: mélanges offerts à Claude Lévi-Strauss à l'occasion de son 60ème. anniversaire. (Tirage à part). Paris: Mouton.p.628-657.

GARDIN, J.-C. (1973a). Document analysis and linguistic theory. The Journal of Documentation, v.29, n.2, pp.137-168, June.

GARDIN, J.-C. (1973b). Linguistique et documentation. Bollettino d'Informazioni, v.13, n.2/ 3 , pp.67-85.

GARDIN, J.-C. (1974). Les analyses de discours. Paris: Delachaux et Niestlé.

GARDIN, J.-C. (1987). La logique, naturelle au autre, dans les constructions des sciences humaines. Revue européene des sciences sociales, v.25, n.77, pp.179-195.

GARDIN, J.-C. (1987). Principes géneraux. In:——_org.). Systemes experts et sciences humaines. Paris: Eyrolles, pp.3-55.

GARDIN, J.-C. (1989). Artificial intelligence and the future of semiotics: an archaeological perspective. Semiotica, v.77, n.1/3, p.5-26.

GARDIN, J.-C. et alii. (1968). L'automatisation des recherches documentaires: un modèle général "Le SYNTOL. 2.ed. revue et augmentée. Paris: Gauthier-Villars.

GARDIN, J.-C. et al. (1987). La logique du plausible: essais d'epistémologie pratique en sciences humaines. Paris: Ed. de la Maison de l'Homme. 
GOMES, H.E. (coord.) (1990). Manual de elaboração de tesauros monolíngües. Brasília: Ministério da Educação/Ministério da Ciência e Tecnologia, Programa Nacional de Bibliotecas das Instituições de Ensino Superior. 78p.

GROLIER, E.de. (1962). Étude sur les catégories générales applicables aux classifications et codifications documentaires. Paris: UNESCO.

IBICT (1984). Diretrizes para elaboração de tesauros monolíngües; projeto coord. por Hagar Espanha Gomes.Brasília: IBICT.

ISO 2788 (1986).British Standard Guide to establishment and development of monolingual thesauri. London: BSI.

KOBASHI, N.Y. (1994). A elaboração de informações documentárias: em busca de uma metodologia. São Paulo: ECA-USP. (Tese de doutorado)

LARA, M.L.G. de (1993). A representação documentária: em jogo a significação. São Paulo: ECA-USP. (Dissertação de Mestrado)

LARA, M.L.G. de (1998). A arquitetura de sistemas de informações estatísticas para disponibilização na Internet. São Paulo em Perspectiva (no prelo).

MANIEZ, J. (1976). Le role de la syntaxe dans les systèmes de recherche documentaire. Dijon: Université de France-Comté. (Thèse pour le doctorat de 3ème. cycle). 2v.

McILWAINE, I.C. (1995). UDC centenary: the present state and future prospects. Knowledge Organization, v.22, n.2, p.64-69.

PIEDADE, M.A.R. (1977). Introdução à teoria da classificação. Rio de Janeiro: Interciência.

RANGANATHAN, S.R. (1959). Elements to library classification. 2.ed. Bombay: Assoc.of Assistant Librarians.

RANGANATHAN, S.R. (1963). Colon Classification. 6.ed. reprinted with amendments. Bombay: Asia Publ. House.

RANGANATHAN, S.R..(1967). Prolegomena to library classification. 3.ed. Bombay, Asia Publ. House.

RIVIER, A. (1992). Construção de linguagens de indexação: aspectos teóricos. Revista da Escola de Biblioteconomia da UFMG, BH, v.21, n.1, p.56-99.

ROSENFELD, L. \& MORVILLE, P. (1998). Informatin architecture for the World Wide Web. Atherton, Ca.: O'Reilly.

SAMPAIO, G.de M. \& PARENTE, L.I.(1997) O aprendizado e a informação no novo paradigma gerencial: as organizações, a relação Estado-Sociedade e a formação do profissional público. Trab. Apresentado à Reunião Annual do Centro Latinoamericano de Administración para el desarrollo, 15-18 out. 1997. (Subtema 'Sistemas de informação sobre serviços públicos para o cidadão: novo canal de relação EstadoSociedade).

SÃO PAULO (Estado). Secretaria de Governo e Gestão Estratégica \& PRODESP - Cia de Processamento de Dados do Estado de São Paulo (1997). Programa de Informação e Informatização. São Paulo, out.

SÃO PAULO (Estado). Secretaria de Economia e Planejamento. Coordenadoria de Análise de Dados. Uma metodologia para sistemas setoriais de informação: Governo do Estado de São Paulo. São Paulo, abr. (Metodologia, 1). 
SENRA, N.C. (1998) A coordenação da estatística nacional: o equilíbrio entre o desejável e o possivel. Rio de Janeiro: 1998. (Tese de Doutorado apresentada à UFRJ).

SHERA, J.H. \& EGAN, M.E. (1969). Catálogo sistemático: princípios básicos e utilização. Trad. de Maria Neile Teles Landau. Brasília: UnB.

SMIT, J.W. (1973). Les langages documentaires comme metalangages du discours scientifique. Paris: École Pratique des Hautes Études. (Mémoire)

SMIT, J.W. (1974). Análise semântica e análise documentária. Rev. Bras. de Semiótica, n.1, p.168-177.

SMIT, J.W. (NATALI) (1976). De l'analyse documentaire à l'analyse poétique: a propos des critiques des "Chats" de Baudelaire. Paris: École Pratique des Hautes Études en Sciences Sociales. (Thèse de 3e. Cycle)

SMIT, J.W. (NATALI) (1978). Documentação e lingüística: inter-relação e campos de pesquisa. Rev. Bras. Bilbiotecon. Doc., v.11, n.1/2, jan./jun.

SMIT, J.W., coord. (1987). Análise Documentária: a análise da síntese. Brasília: IBICT.

TÁLAMO, M.F.G.M. A definição semântica (1987). In: SMIT, J., org. Análise documentária: a análise da síntese. Brasília: IBICT.

TÁLAMO, M.F.G.M. (1997). Linguagem documentária. São Paulo: APB. (Ensaios APB, n.45).

TÁLAMO, M.F.G.M. et alii. (1990). Instrumentos de controle terminológico: limites e funções. Trab. apresentado ao II Simpósio Latinoamericano de Terminologia. Brasília, 9-4 set, 1990.

TÁLAMO, M. F.M; LARA, M.L.G. \& KOBASHI, N.Y. (1992) Contribuição da Terminologia para a elaboração de tesauros. Ciência da Informação, v. 21, n.3, p. 197-200.

TÁLAMO, M.F.G.M. (1991). Terminologia, linguagens documentárias e representação do conhecimento. Trab. apresentado ao Congresso Nacional de Informação - SUCESU, 23-27 set. 1991.

TEIXEIRA COELHO NETTO, J. (1996). Do paradigma do acervo para o paradigma da informação. In: ANAIS. Simpósio Sul-Brasil de Informação, Londrina, 1996. p.15-30.

TOKAIRIM, V.L., coord.(1998). Guia de informações sobre serviços públicos: treinamento no aplicativo em "Notes”. São Paulo: Sec. Gov. Gestão Estratégica; PRODESP, nov.

UNISIST (1978). Princípios de indexação. R. Esc. Bibliotec. UFMG, Belo Horizonte, v.10, n.1, pp.83-94, mar.

UNIVERSIDADE DE SÃO PAULO (1997). SAUSP - Sistema de Arquivos da Universidade de São Paulo, portaria GR no.3083.97, anexo II: Plano de classificação das atividades da Universidade de São Paulo. São Paulo.

URBAN, A.E, (1994). Gestão de recursos da informação na administração pública. São Paulo em Perspectiva: revista da Fundação SEADE, v.8, n.4, out./dez.

VICKERY, B.C. (1963). La classification à facettes: guide pour la construction e l'utilisation de schémas spéciaux. Paris: Gauthier-Villars.

VICKERY, B.C. (1980). Classificação e indexação nas ciências. Trad. de Maria Christina Girão Pirolla. Rio de Janeiro: BNG/Brasilart.

VIET, J. (1985). Macrothesaurus para el procesamiento de la información relativa al desarrollo econmico y social. 3. ed. New York: Naciones Unidas. 
VIET, J. (1986). Thesaurus POPIN: thesaurus multilingüe de população. Trad. e adapt. de Letícia B. Costa. São Paulo: SEADE.

XIAO, Y. (1994). Faceted classification: a consideration of its features as a paradigm of knowledge organization. Knowledge Organization, v.21, n.2, p.64-68.

\section{TERMINOLOGIA/SOCIOTERMINOLOGIA}

ASSAL, A. (1994). La notion de notion en terminologie. Meta, v.39, n.3, p.460-464.

BAUDET, J.-C. (1995). Éditologie: une sociolinguistique de la science. Meta, v.40, n.2, p.216-223. BÉJOINT, H. (1989). À propos de la monosémie en terminologie. Meta, v.34, n.3, pp.405-411. BÉLANGER, G. (1991). Pour une nouvelle terminographie. Meta, v.36, n.1, p.49-54.

BOULANGER, J.-C. ((1995). Présentation: images et parcours de la socioterminologie. Meta, v.40, n.2, p.194-205.

BOURCIER, D. (1976). Argumentation et définition en droit ou "Les grenouilles sont-elles des poissons?". Langages, n.46, p.115-124.

BOUTIN-QUESNEL, R. et al.(1985). Vocabulaire systématique de Terminologie. Québec: Publications du Québec.

BUDIN, G. (1996). Wissensorganisation und Terminologie: Die Komplexität und Dynamik wissenschaftlicher Informations und Kommunikationsprozesse. [Knowledge organization and terminology: the complexity and dynamics of scientific information and communication processes]. (Forum für Fachsprachenforschung, 28). Tübingen: Narr, VII-II, 268p.

WRIGHT, S.E. (1997). [Book review]. Knowledge organization, v.24, n.3, pp.190-192.

CABRÉ, M.T. (1993). La terminología: teoría, metodologia, aplicaciones. Barcelona: Ed. Antártida; Empúries.

CABRE, M.T. (1991). Terminologie ou terminologies? specialité linguistique ou domaine interdisciplinaire? Meta, v.36, n.1, 55-63.

CABRÉ, M.T. (1994). Terminologie et dicionnaires. Meta, v.39, n.4, p.589-597.

COLE, W.D. Descriptive terminology: some theoretical implications. Meta, v.36, n.1, p.16-22.

DANON-BOILEAU, L. (1976) Sur la “logique"du texte de loi. Langages, n.46, p.111-114, juin.

DESMET, I.(1990). Questões de semântica em terminologia: a problemática da definição terminológica. Terminologias, n.2, 4-21, dez.

DUBOIS, J. \& C. (1971). Introduction à la lexicologie: le dictionnaire.Paris: Larousse.cap. 6-11.

DUBUC, R. (1977). Qu'est-ce que la terminologie? Le banque des mots, Paris, n.13, pp.3-14.

FELBER, (1987). Manuel de terminologie. Paris: Unesco/Infoterm.

GAMBIER, (1991). Travail et vocabulaire spécialisés: prolégomènes à une socio-terminologie. Meta, v.36, n.1, p.8-15, 1991

GAUDIN, F. (1995). Champs, clôtures et domaines; des langues de spécialités à la culture scientifique. Meta, v.40, n.2, p.229-237.

GAUDIN, F. (1993). Pour une socioterminologie: des problèmes semantiques aux pratiques institutionneles. Rouen, Université de Rouen. (Publications de Lúniversité de Rouen, 182)

GAUDIN, F. (1993). Socioterminologie: du signe au ens, construction d'un champ. Meta, v.38, 
n.2, p.293-301.

GUESPIN, L. (1995). La circulation terminologique et les rapports entre science, technique et production. Meta, v.40, n.2, p.206-215.

HERMANS, A. (1989). La définition des termes scientifiques. Meta, v.34, n.3, pp.529-532.

HERMANS, A. (1995). Sociologie des discours scientifiques: quelques réflexions. Meta, v.40, n.2, p.224-228.

ISO 1087 (1994). Terminologia - vocabulário. Proposta de versão brasileira.

ISO 704 (1987). Principles and methods of Terminology. Génève: ISO.

ISO 704 (1994). Princípios e métodos da atividade terminológica. Proposta de norma brasileira.

LE GUERN, M. (1989). Sur les relations entre terminologie et lexique. Meta, v.34, n.3, p.340-343.

RASTIER, F. (1995). Le terme: entre ontologie et linguistique. La Banque des Mots. Numéro spécial 7, Terminoloagie et Intelligence Artificielle.

REBOUL, S. (1995). Télematique et socioterminologie. Meta, v.40, n.2, p.296-307.

REY, A. (1977). Le lexique, images et modèles: du dicitionnaire à la lexicologie. Paris: Armand Colin. cap. 1 e 4.

RONDEAU, G. (1984). Introduction à la terminologie. 2.ed. Québec: Gaëtan Morin Ed.

SAGER, J.C. (1990). A practical course in terminology processing. Amsterdam/ Philadelphia: John Benjamins.

SAGER, J.C. (1993). Prólogo: la terminología, puente entre varios mundos. In: CABRÉ, M.T. (1993). La terminología: teoría, metodologia, aplicaciones. Barcelona: Ed.Antártida; Empúries. p.11-17.

SLODZIAN, M. (1995). Transfert de connaissances nouvelles et aménagement terminologique. Meta, v.40, n.2, p.238-243.

\section{LINGÜÍSTICA/SEMIÓTICA}

BACCEGA, M.A. (1995). Palavra e discurso: história e literatura. São Paulo: Ática.

BARBOSA, M.A.. (s.d.) Da função semiótica, das funções metassemioticas e suas aplicações à elaboração da macro e da microestrutura e do processo de remissivas da obra lexicográfica. São Paulo: FFLCH-USP.

BARTHES, R. (1971). Elementos de semiologia. São Paulo: Cultrix.

BENVENISTE, É. (1991). Problemas de lingüística geral, I. Campinas: Pontes; Ed. UNICAMP.

DASCAL, M.(1978). Las sémiologies contemporaines. In:__La sémiologie de Leibniz. Paris, Aubier Montaine. cap. 2.

DUBOIS, J. et al. (1973). Dicionário de Lingüistica. Trad. de Frederico Pessoa de Barros e outros. São Paulo: Cultrix.

DUCROT, O. (1981). Provar e dizer: linguagem e lógica. São Paulo: Global.

DUCROT, O. \& TODOROV, T. (1988) Dicionário enciclopédico das Ciências da Linguagem. Trad. de Alice Kyoko Miyashiro e outros. 2.ed. rev. ampl. São Paulo:

Perspectiva. 
ECO, U. (1984). Conceito de texto. Trad. de Carla de Queiroz. São Paulo: TA Queiroz; EDUSP.

ECO, U. (1986). Lector in fabula: a cooperação interpretativa nos textos narrativos. Trad. de Attílio Cancian. São Paulo: Perspectiva. (Estudos, 89)

ECO, U.(1991). Semiótica e filosofia da linguagem. Trad. de Mariorosaria Fabris e José Luis Fiorin. São Paulo : Ática. (Fundamentos, 64)

ECO, U. (1973). O signo. Trad. de Maria de Fátima Marinho. Lisboa: Ed. Presença.

GRANGER, G.G. (1974). Filosofia do estilo. Trad. de Scarlett Zebetto Marton. São Paulo: Perspectiva; EDUSP. (Estudos, 29)

GREIMAS, A.-J. (1976). Semântica estrutural: pesquisa de método. São Paulo: Cultrix; Universidade de São Paulo.

LOPES, E.(1987). Fundamentos da lingüistica contemporânea. São Paulo: Cultrix.

LOPES, E. (1978) Discurso, texto e significação: uma teoria do interpretante. São Paulo: Cultrix; Sec.Cultura, Ciência e Tecnologia do ESP.

LOPES, E. (1997). A identidade e a diferença. São Paulo : EDUSP.

LYONS, J. (1977). Semântica. Lisboa: Ed. Presença; Martins Fontes. v.1.

PEIRCE, C.S. (1977). Semiótica. Trad. José Teixeira Coelho Netto; rev. J. Guinsburg. São Paulo: Perspectiva. (Estudos, n.46).

PEÑUELA CANIZAL, e. (1978). Prefácio. In: LOPES, E. (1987). Fundamentos da lingüistica contemporânea. São Paulo: Cultrix.

SANTAELLA, L. (1993). A percepção: uma teoria semiótica. São Paulo: Experimento.

\section{FILOSOFIA/SOCIOLOGIA/ANTROPOLOGIA/ESTUDOS CULTURAIS}

BOURDIEU, P.(1983). O campo científico. Trad.de Paula Montero. In: ORTIZ, R., org., São Paulo: Ática. p.141.

COELHO, J. Teixeira. Moderno pós moderno: modos \& versões. 3.ed. ampl. São Paulo: Iluminuras, 1995.

COPI, I. M. (1978). Introdução à lógica. São Paulo: Mestre Jou.

DELEUZE, G. \& GUATTARI, F. (1992). O que é filosofia? Rio de Janeiro: Ed. 34.

DIDEROT, D. (1989). Enciclopédia, s.f. (Filosofia). Trad. de Marcelo Coelho e Marco Chiaretti. Folha de São Paulo, 9 dez. 1989, p.G-1. (Letras)

FEYERABEND, P.(1989) Contra o método. 3.ed. Rio de Janeiro: Francisco Alves.

FOUCAUT, M.(1966). Prefácio. In:___ As palavras e as coisas: uma arqueologia das ciências humanas. São Paulo: Martins Fontes.

LEFEBVRE, L. (1975). Lógica formal, lógica dialética. Rio de Janeiro: Civilização Brasileira.

MACHADO, N.J. (1995). Epistemologia e didática: concepções de conhecimento e inteligência e a prática docente. São Paulo: Cortez.

MATUS, C. (1993). Política, planejamento e governo. Brasília: IPEA. 2 v. (Série IPEA, 143) 
JAMESON, F. (1991). Postmodernism or the cultural logic of late capitalism. Durham:

Duke Univ. Press, 1991.

MAFFESOLLI, M. (1991). Aux creux des apparences. Paris: Poche, 1991.

NUNES, B. (1998). Nós somos um diálogo. São Paulo, Jornal de Resenhas, Folha de São Paulo, 08.ago., Cad. Especial, p.10 (Caderno Discurso Editoria/USP/Unesp)

PRADO JR., Bento (1994). O relativismo como contraponto. In: BANCO NACIONAL DE IDÉIAS. O relativismo enquanto visão do mundo. São Paulo: Francisco Alves. pp.71-94.

RORTY, Richard (1994). Relativismo: encontrar e fabricar. In: BANCO NACIONALDE IDÉIAS. O relativismo enquanto visão do mundo. São Paulo: Francisco Alves. pp. 115-134.

RORTY, Richard,(1988). A filosofia e o espelho da natureza. Lisboa: Dom Quixote.

SANTOS, B. de (1989). Introdução a uma ciência pós-moderna. Rio de Janeiro : Graal.

TEIXEIRA COELHO, J. (1997). Dicionário crítico de política cultural: cultura e imaginário. São Paulo : FAPESP; Iluminuras.

TEIXEIRA COELHO, J. (1995). Moderno pós-moderno: modos \& versões. 3.ed. ampl. São Paulo: Iluminuras. 